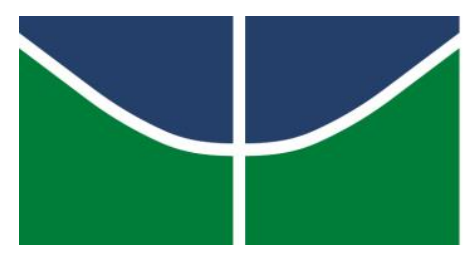

UNIVERSIDADE DE BRASÍLIA - UnB

INSTITUTO DE LETRAS - IL

DEPARTAMENTO DE LINGUÍSTICA, PORTUGUÊS E LÍNGUAS CLÁSSICAS - LIP PROGRAMA DE PÓS-GRADUAÇÃO EM LINGUÍSTICA - PPGL

\title{
NARRATIVAS MIDIÁTICAS MULTIMODAIS \\ E SEUS EFEITOS SOCIAIS
}

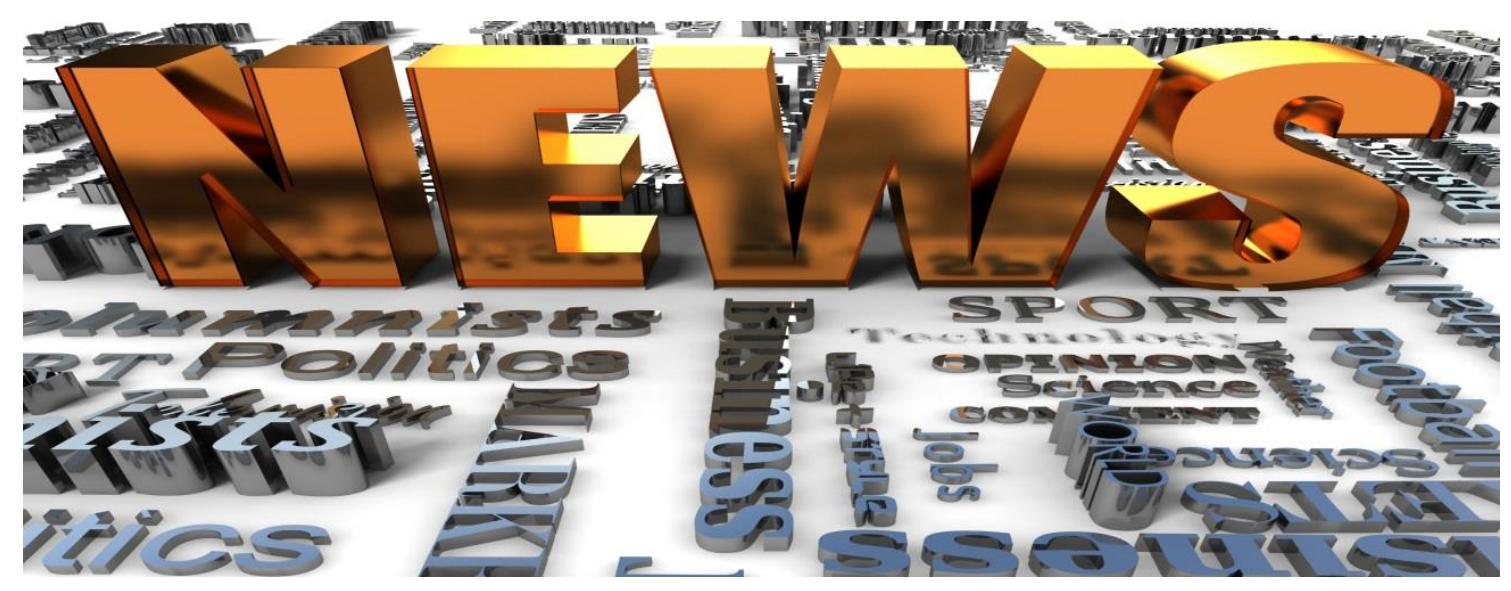

BRASÍLIA (DF) 
UNIVERSIDADE DE BRASÍLIA

INSTITUTO DE LETRAS

DEPARTAMENTO DE LINGUÍSTICA, PORTUGUÊS E LÍNGUAS CLÁSSICAS

PROGRAMA DE PÓS-GRADUAÇ̃̃O EM LINGUÍSTICA

DOUTORADO EM LINGUIISTICA

SIMONE MARIA ABRAHÃO SCAFUTO

\section{NARRATIVAS MIDIÁTICAS MULTIMODAIS \\ E SEUS EFEITOS SOCIAIS}

Tese apresentada como requisito parcial para a obtenção do título de Doutor em Linguística à Banca Examinadora do Programa de Pós-Graduação em Linguística da Universidade de Brasília (UnB).

Orientadora: Profa. Dra. Josenia Antunes Vieira

Brasília (DF)

2015 
NARRATIVAS MIDIÁTICAS MULTIMODAIS E SEUS EFEITOS SOCIAIS

SIMONE MARIA ABRAHÃO SCAFUTO

BANCA EXAMINADORA

Profa. Dra. Josenia Antunes Vieira - Orientadora

Presidente (UnB/LIP)

Profa. Dra. Elizete de Azevedo Kreutz

Membro Efetivo Externo (Univates/RS)

Profa. Dra. Regina Célia Pagliuche da Silveira Membro Efetivo Externo (PUC/SP)

Profa. Dra. Francisca Cordélia Oliveira da Silva

Membro Efetivo Interno (UnB/LIP)

Prof. Dr. Guilherme Veiga Rios

Membro Efetivo Interno (UnB/LIP)

Prof. Dr. André Lúcio Bento

Membro Suplente (UaB/UnB) 
O lugar da camunicaçãa visual em uma dada saciedade sá pade ser entendida na cantexta da gama de farmas au de madas púlelicas de camunicaçãa dispanúueis nessa saciedade e nas suas utilizaçães e aualiaçães.

Tress e van Leewwen, 2006, p. 35.

Tara demonstrarmas cama as narrativas afetam as decisães e as açães humanas, au cama elas padem, de farma cantingencial, ter efeitas sabre as mudanças saciais e ecanâmicas, devemas vê-las cama canstruçães semiáticas que passuem elementas de argumentas práticas.

Fairclaugh, 2012, p. 4. 


\section{AGRADECIMENTOS}

A Deus, amado Pai soberano, por sua constante presença em minha vida.

Ao Cláudio Scafuto, meu marido, à Danielle e à Aline, nossas filhas, pelo apoio.

À Professora Doutora Josenia Antunes Vieira, por ter-me orientado com profundidade e amplitude de conhecimento, experiência e firmeza.

Aos Professores do Programa de Pós-Graduação que contribuíram para minha formação acadêmica.

Ao Programa de Pós-Graduação em Linguística.

À Banca Examinadora, especialmente, à Professora Francisca Cordélia Oliveira da Silva e à Professora Elizete de Azevedo Kreutz, pelas leituras e pelos comentários.

Às colegas pesquisadoras Eni Batista e Neiva Soares, pela solidariedade.

À amiga Carmen Lucia Prata da Costa, pela valiosa colaboração.

À Secretaria do Programa de Pós-Graduação, por sua presteza no atendimento.

Ao Conselho Nacional de Pesquisa, CAPES, pelo apoio financeiro.

Às alunas e aos alunos.

A todos que me incentivaram, para que este estudo se concretizasse. 


\section{RESUMO}

Esta pesquisa qualitativa desenvolve-se na linha Discursos, Representações Sociais e Textos da área de Linguagem e Sociedade, do Programa de Pós-Graduação em Linguística, com o objetivo de analisar os modos de construção de sentido ideológico de narrativas multimodais difundidas pela mídia contemporânea e os efeitos sociais produzidos por essas formas semióticas. Defende a tese de que narrativas midiáticas multimodais são um gênero de texto produzido sob o controle de modelos de contextos, em cujo formato tecnológico os elementos são representados e modalizados para ter efeitos de sentido sobre as condutas sociais; portanto, não são (re)produções fiéis da realidade como é do senso comum. O estudo multidisciplinar fundamenta-se com base na Teoria Semiótica Social da Multimodalidade e na Análise de Discurso Crítica, teorias sociais da linguagem que mantêm diálogo irredutível com as Ciências Sociais Críticas, e com base na Teoria Sociocognitiva do Contexto, perspectiva que se desenvolve no âmbito dos estudos do discurso. Esta pesquisa crítica responde às três seguintes questões. Como as narrativas multimodais difundidas pela mídia global são estrategicamente organizadas para ter efeitos sociais? De que modo os participantes das estruturas narrativas midiáticas são representados ideologicamente? Como são modalizadas as narrativas midiáticas multimodais manipuladas pela mídia impressa? São analisados os contextos de narrativas multimodais veiculadas por revistas nacional e internacional de alcance global e de alto consumo bem como categorias sistematizadas pela Multimodalidade e pela Análise de Discurso Crítica, além dos efeitos sociais provocados pelas formas. As análises semióticas críticas revelam que as novas narrativas midiáticas são um gênero global especializado, em cujo formato tecnológico os modos da escrita e do visual são organizados com significados ideológicos que legitimam e perpetuam relações de poder e de dominação. No que diz respeito aos elementos representados nos textos multimodais, as análises mostram que os eventos reais são narrados de acordo com os interesses econômicos políticos das instituições das quais eles saem e que os participantes atores das estruturas narrativas estéticas são configurados de modo a satisfazer pontos de vista particulares. Quanto aos marcadores de modalidade usados nas composições semióticas, as análises demonstram que os sentidos ideológicos manipulados pela mídia contrastam com significados dos relatos dos eventos da realidade. Como esperado, narrativas multimodais difundidas pela mídia de massa são planejadas para produzir efeitos de sentido de curto e de longo prazos sobre a vida em sociedade, sejam esses efeitos negativos, sejam positivos.

Palavras-chaves: Narrativas. Mídia Global. Multimodalidade. Análise Semiótica Crítica. 
This qualitative research develops in line Discourses, Social Representations and Texts the area of Language and Society, of the Graduate Program in Linguistics, in order to analyze the ways of building ideological sense of multimodal narratives disseminated by contemporary media and the social effects produced by these semiotic forms. Takes the view that multimodal media narratives are a text genre produced under the control models of contexts in which technological format elements are represented and modalizaded to have meaning effects on social behavior; therefore, they are not (re) productions faithful to reality as is common sense. The multidisciplinary study is grounded based on the Theory of Social Semiotics Multimodality and Critical Discourse Analysis, Social Theories of Language that keep irreducible dialogue with the Social Sciences Reviews, and based on Socio-Cognitive Theory of Context, perspective that develops within of discourse studies. This critical research answers the following three questions. How multimodal narratives circulated by global media are strategically arranged to have social effects? How the participants of the media narrative structures are represented ideologically? How are modalizaded multimodal media narratives handled by the print media? The contexts of multimodal narratives conveyed by national and international magazines global reach and high consumption and systematized categories by Multimodality and Critical Discourse Analysis are analyzed in addition to the social effects caused by the forms. Critical semiotic analysis reveals that new media narratives are a specialized global genre, in which the technological format of writing and visual modes are organized ideological meanings that legitimize and perpetuate relations of power and domination. With regard to the elements represented in multimodal texts, the analyzes show that the actual events are narrated in accordance with the political economic interests of the institutions of which they leave and the actors involved the aesthetic narrative structures are configured to meet points private view. As for the type of markers used in semiotic compositions, the analysis shows that the ideological way manipulated by the media contrasts with the reports of meanings of reality events. As expected, multimodal narratives disseminated by the mass media are designed to produce meaning effects of short and long-term about life in society, are these negative effects are positive.

Keywords: Narratives. Global media. Multimodality. Semiotic Critical Analysis. 


\section{LISTA DE FIGURAS}

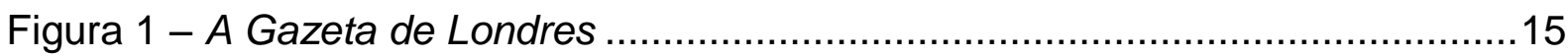

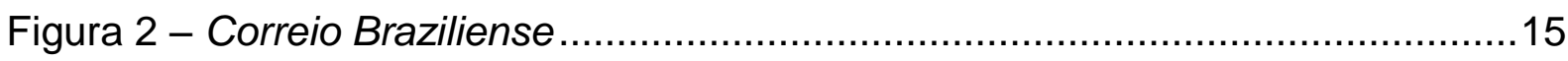

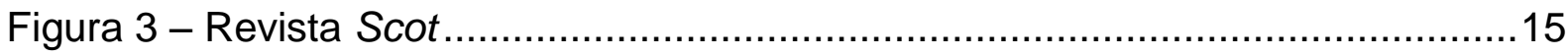

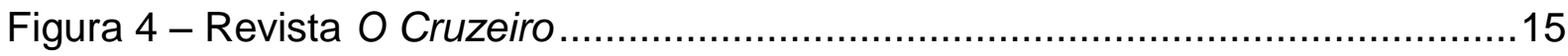

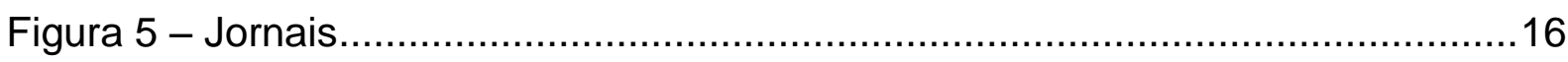

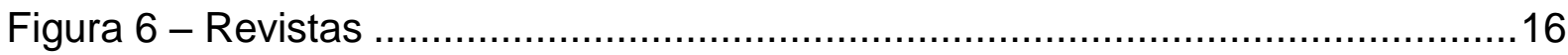

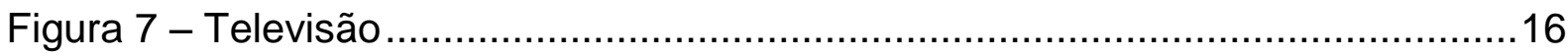

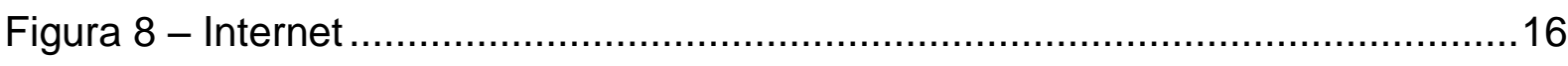

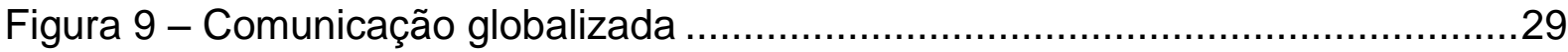

Figura 10 - Desvalorização do Real .................................................................

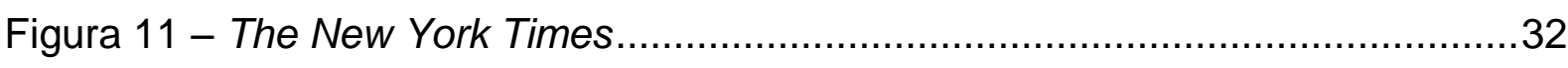

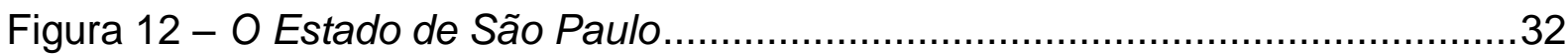

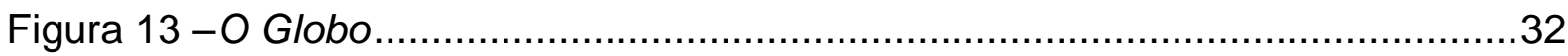

Figura 14 - Corriere Della Sera......................................................................

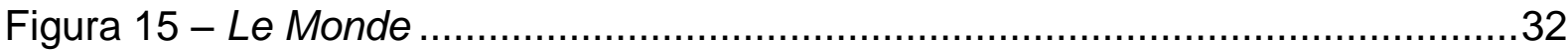

Figura 16 - Seminudez da Princesa Kate …................................................... 40

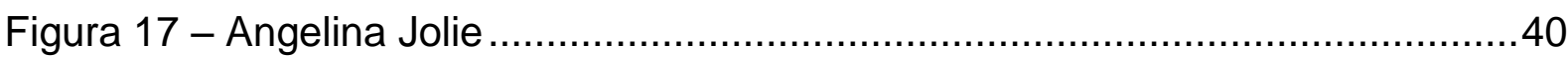

Figura 18 - Heróis americanos ………........................................................ 43

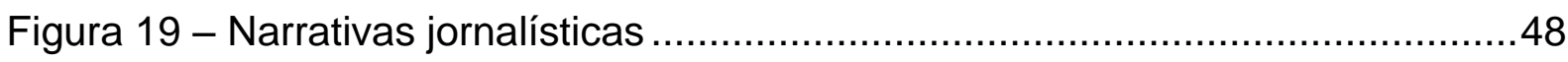

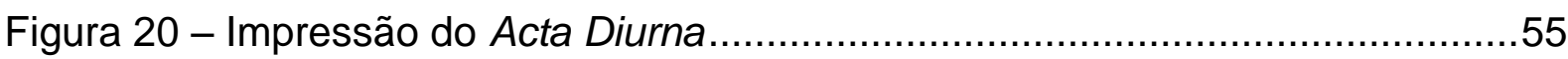

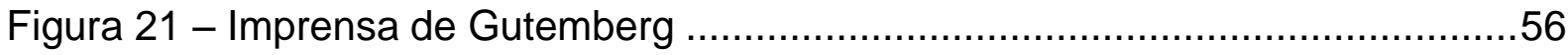

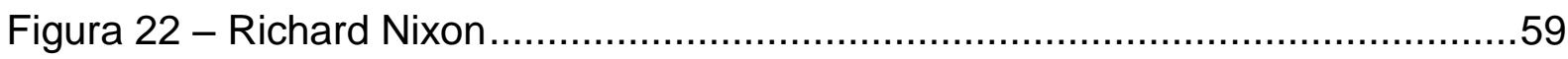

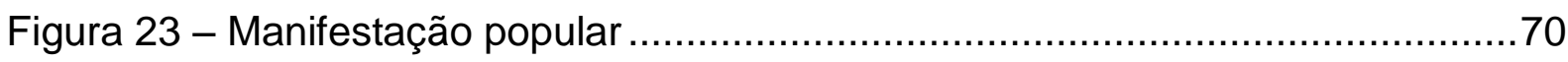

Figura 24 - Manifestação popular ……………….........................................

Figura 25 - Partido dos Trabalhadores ..........................................................

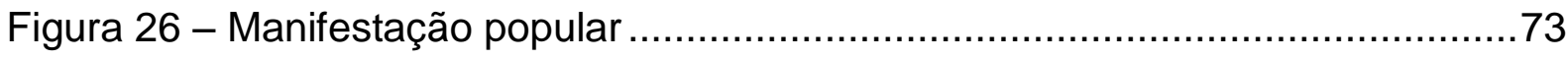

Figura 27 - Marconi Perillo na Comissão Nacional de Inquérito ………………......75

Figura 28 - Hakimullah Mehsud...................................................................... 


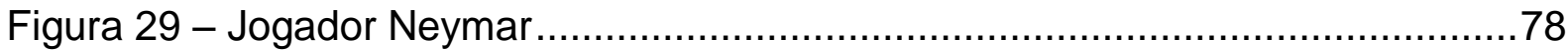

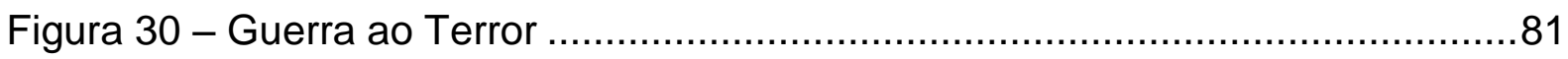

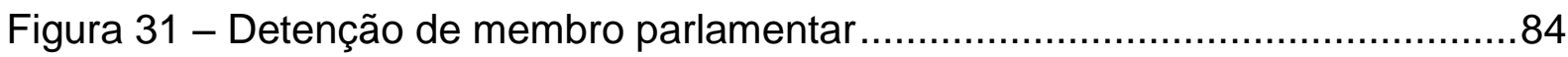

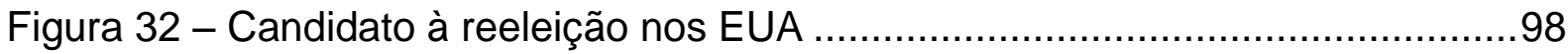

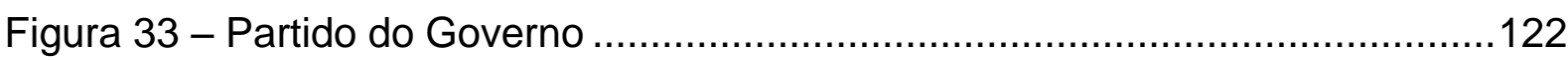

Figura 34 - Primeiro-ministro da Espanha …………......................................122

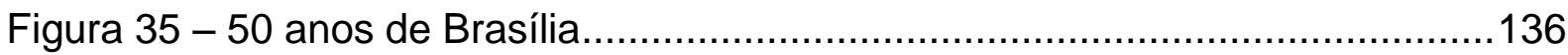

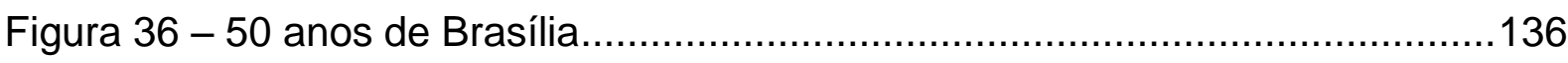

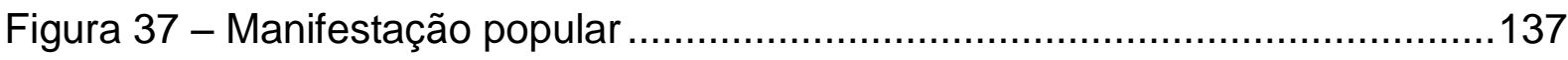

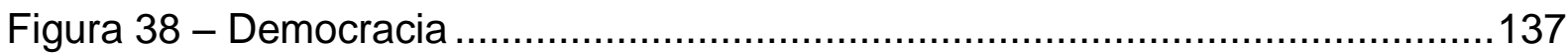

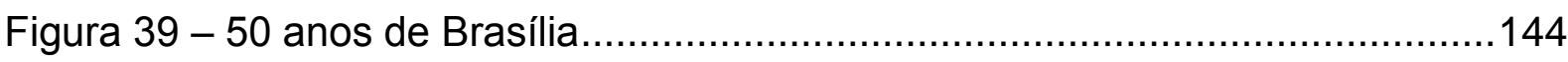

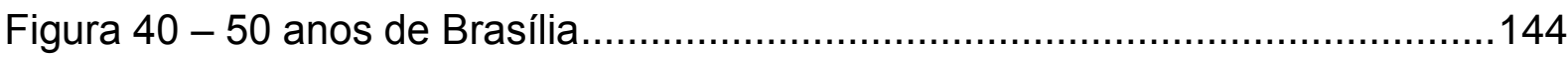

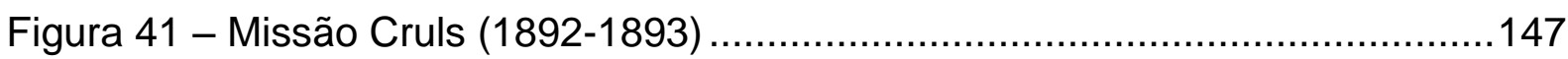

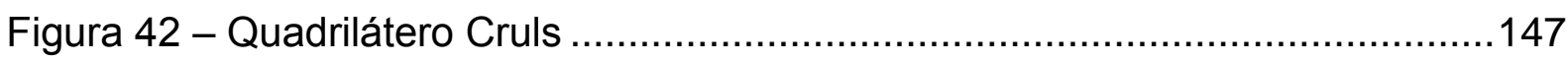

Figura 43 - Missão José Pessoa (1954) ………………...............................147

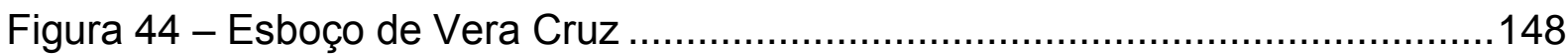

Figura 45 - Maquete de Brasília, 22/11/1958 ................................................148

Figura 46 - Plano urbanístico de Brasília - DF ...............................................148

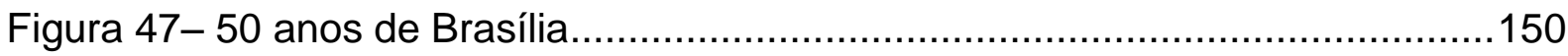

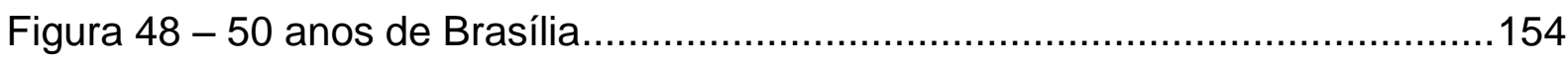

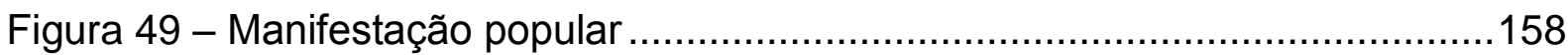

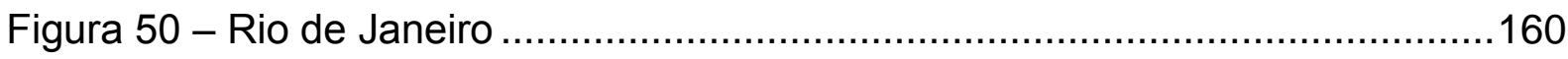

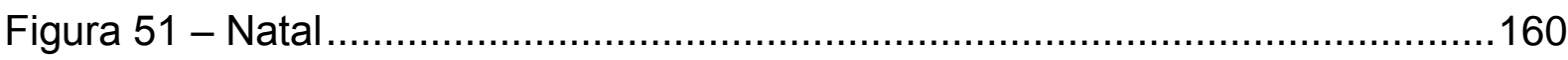

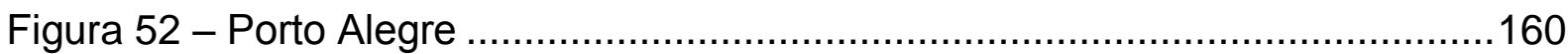

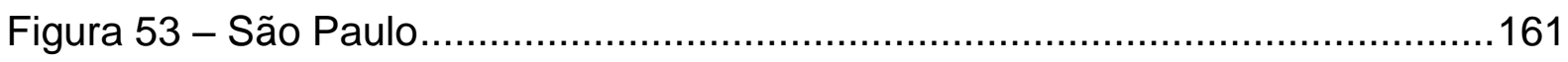

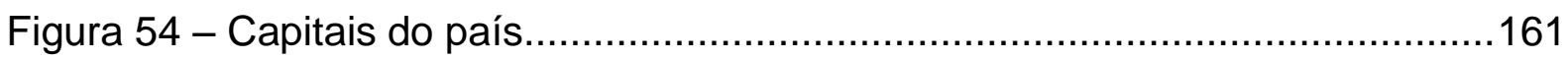

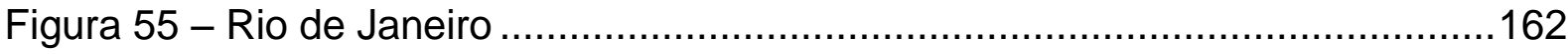

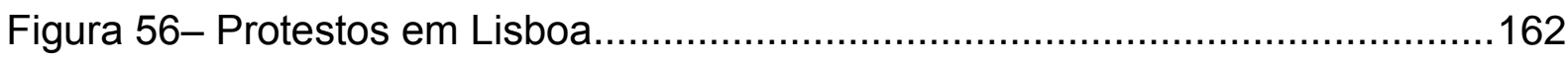

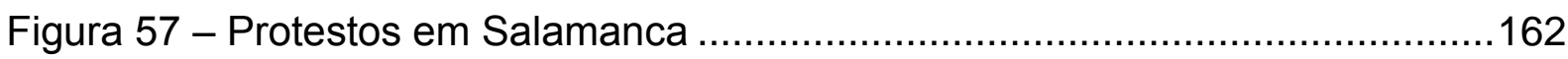

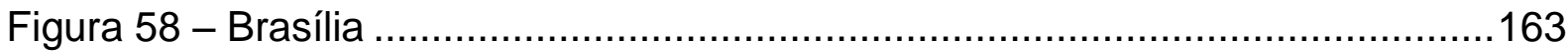

Figura 59 - Pronunciamento da Presidente do Brasil ..........................................165 


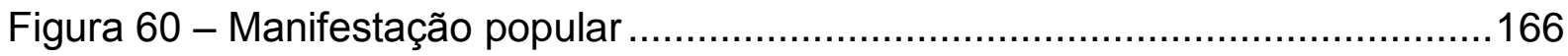

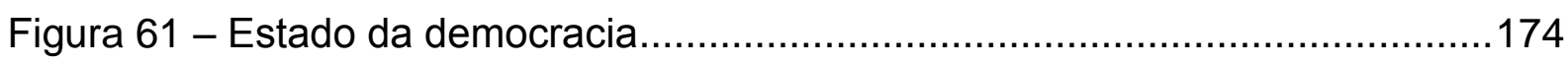

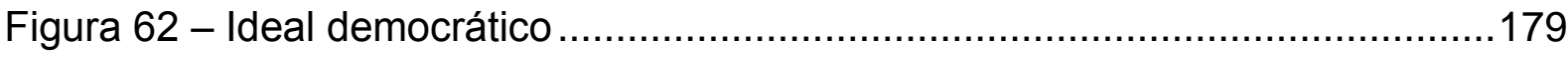

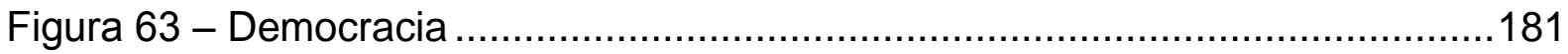




\section{LISTA DE QUADROS}

Quadro 1 - Pré-estruturação de uma narrativa midiática ...................................45

Quadro 2 - Linha de evolução do jornalismo: crescimento, auge e declínio.............60

Quadro 3 - Consumo do meio impresso por classes sociais ...............................61

Quadro 4 - Modos de operação da ideologia...................................................69

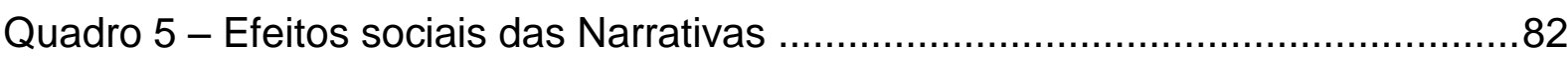

Quadro 6 - Narrativização em imagens subjetivas ...........................................90

Quadro 7 - Narrativização em imagens objetivas .........................................91

Quadro 8 - Princípios da composição de significados em imagens........................95

Quadro 9 - Categorias analíticas da Multimodalidade .......................................97

Quadro 10 - Participantes da representação narrativa ................................... 101

Quadro 11 - Configuração esquemática dos processos narrativos ......................106

Quadro 12 - Circunstâncias no padrão narrativo ............................................107

Quadro 13 - Escala de modalidade (saturação da cor) ...................................112

Quadro 14 - Gênero discursivo................................................................ 121

Quadro 15 - Bases das categorias de análise .........................................133

Quadro 16 - Categorias aplicadas às narrativas midiáticas multimodais...............141

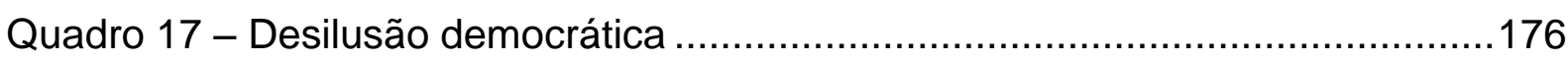




\section{SUMÁRIO}

INTRODUÇÃO

CAPÍTULO 1 .......................................................................................................22

CONTEXTOS GLOBAIS E NARRATIVAS DA MÍDIA CONTEMPORÂNEA ............22

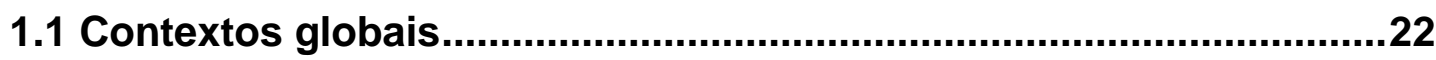

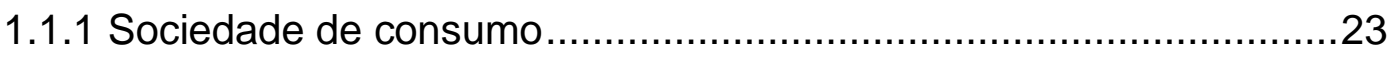

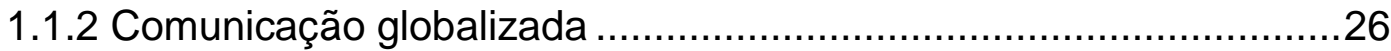

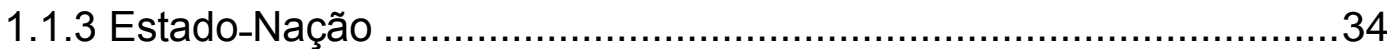

1.1.4 Mídia, mediação e a quase interação mediada...............................36

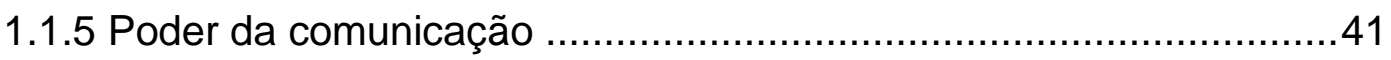

1.2 Narrativas da mídia contemporânea ..................................................44

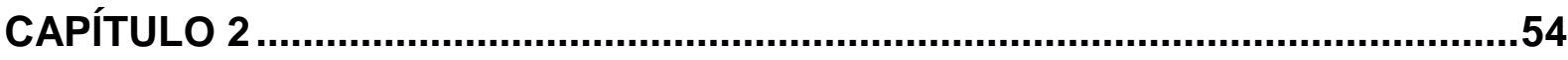

CONTEXTOS LOCAIS, MODOS DA IDEOLOGIA E EFEITOS SOCIAIS ................54

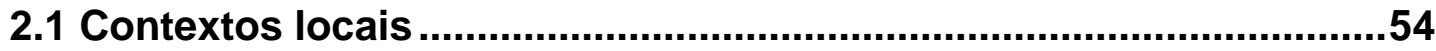

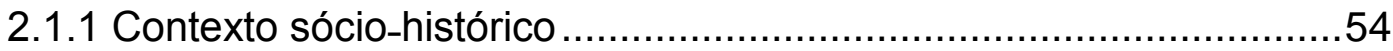

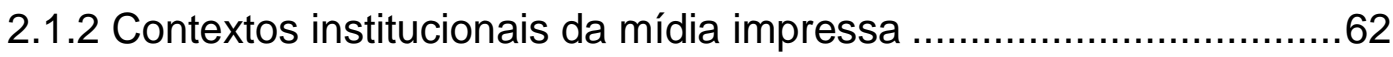

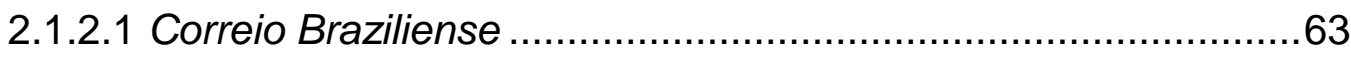

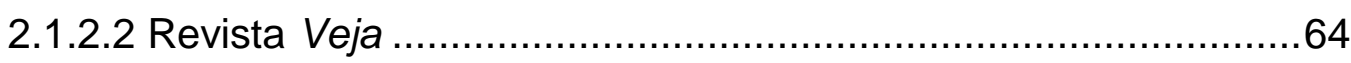

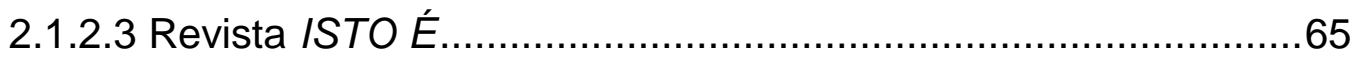

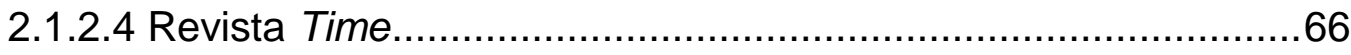

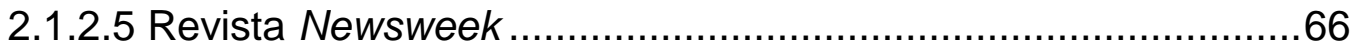

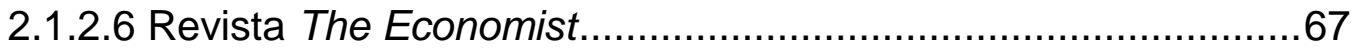

2.2 Modos estratégicos de operação da ideologia ...................................68

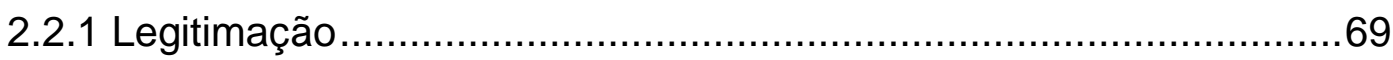

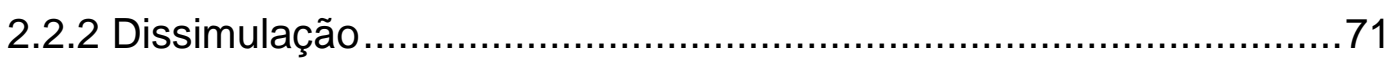

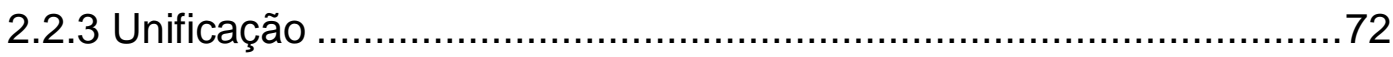

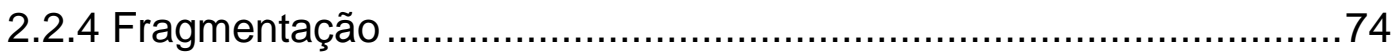

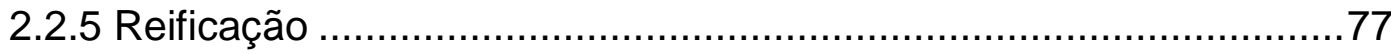

2.3 Narrativas argumentativas midiáticas e seus efeitos sociais............79 
FUNDAMENTOS TEÓRICOS MULTIDISCIPLINARES …....................................86

3.1 Teoria Semiótica Social da Multimodalidade .....................................86

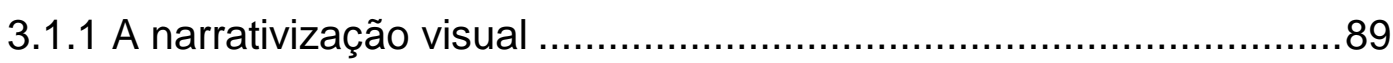

3.1.2 A composição de significados ...................................................92

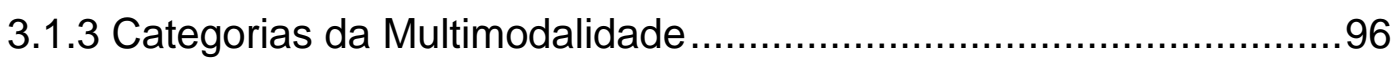

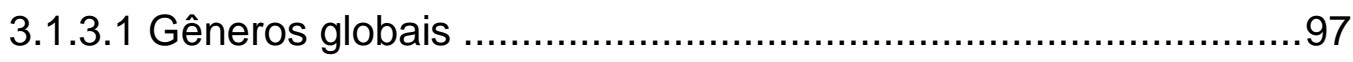

3.1.3.2 Representação narrativa ...................................................100

3.1.3.2.1 Participantes .............................................................. 101

3.1.3.2.2 Processos narrativos..................................................103

3.1.3.2.3 Circunstâncias ...........................................................107

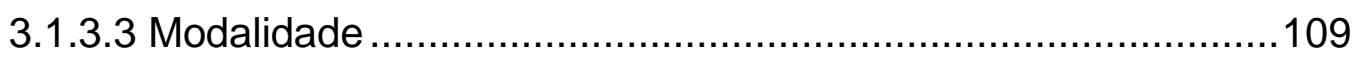

3.1.3.3.1 Marcadores de modalidade............................................111

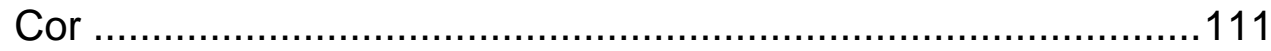

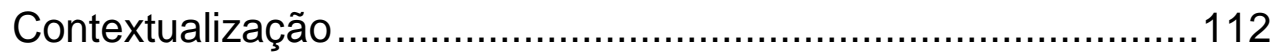

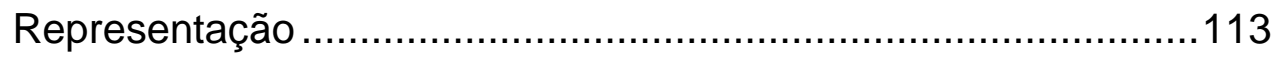

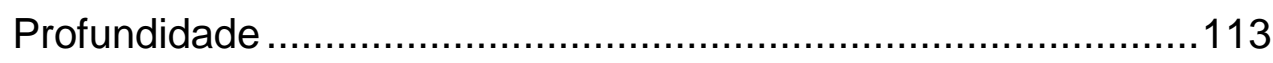

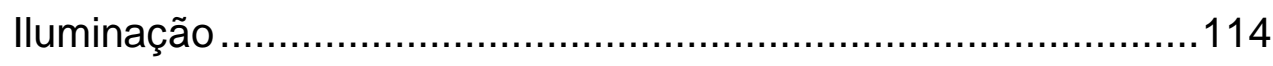

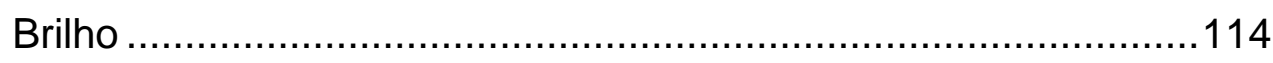

3.2 Análise de Discurso Crítica (ADC) .................................................115

3.2.1 Narrativas jornalísticas: uma perspectiva crítica ..........................118

3.2.2 Gênero discursivo como categoria de análise..............................120

3.3 Teoria Sociocomunicativa da Ideologia ........................................123

3.4 Teoria Sociocognitiva do Contexto..............................................126

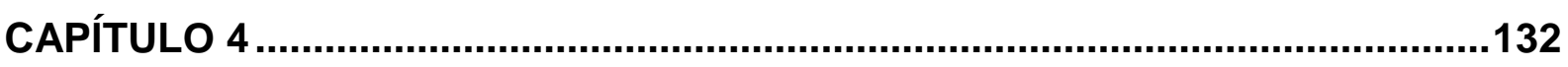

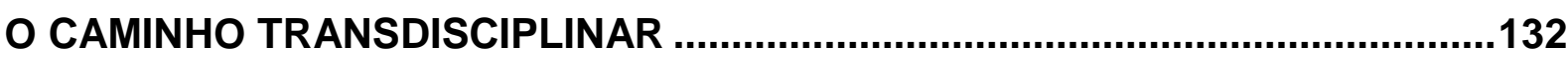

4.1 Tese e questões de pesquisa ......................................................134

4.2 Amostra representativa de dados .................................................134

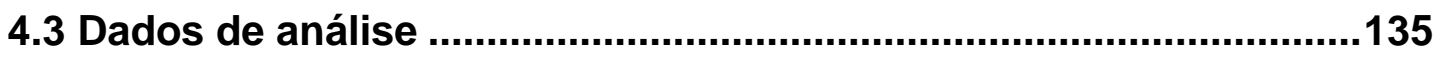

4.4. Metodologias analíticas ...............................................................138

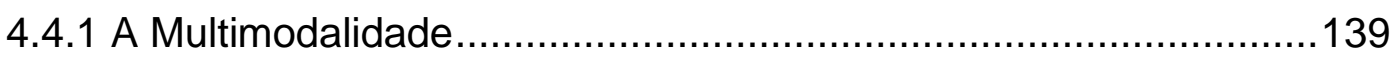

4.4.2 Análise de Discurso Crítica .......................................................139

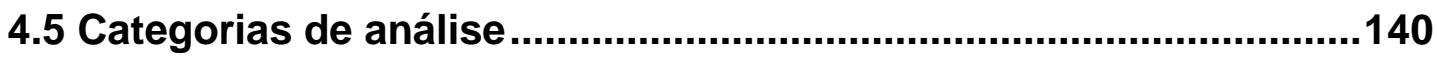


ANÁLISES SEMIÓTICAS CRÍTICAS DE NARRATIVAS MULTIMODAIS DA MÍDIA

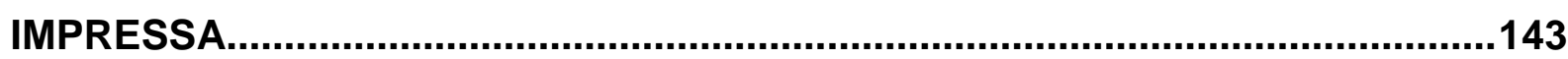

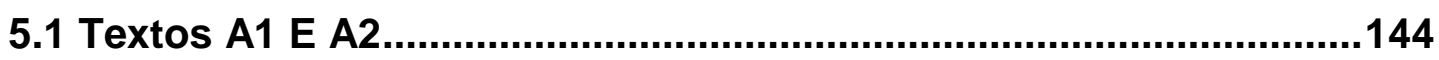

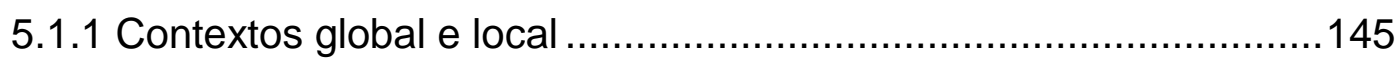

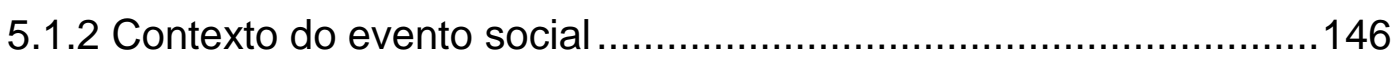

5.1.2.1 Análise do Texto A1 .......................................................150

5.1.2.1.1 Gênero discursivo e gênero global................................151

5.1.2.1.2 Representação narrativa ................................................152

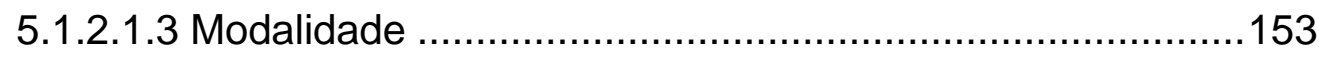

5.1.2.1.4 Ideologia e efeito social da narrativa................................153

5.1.2.2 Análise do Texto A2 .......................................................154

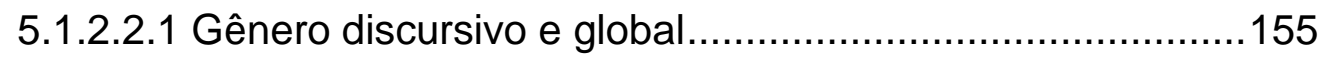

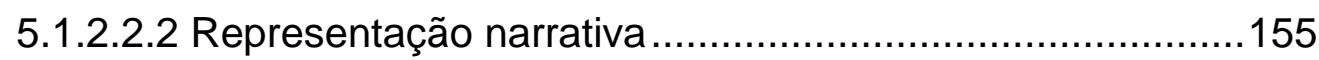

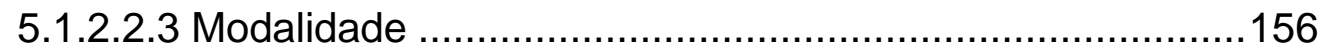

5.1.2.2.4 Ideologia e efeito social da narrativa...............................157

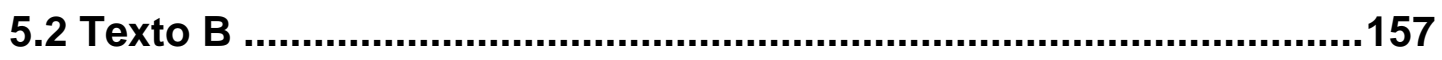

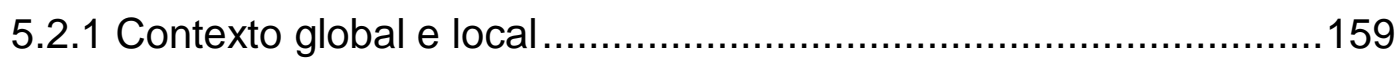

5.2.1.1 Contexto do evento social .................................................160

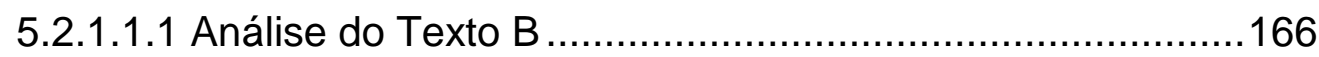

5.2.1.1.1.1 Gênero discursivo e global .....................................167

5.2.1.1.1.2 Representação narrativa .........................................169

5.2.1.1.1.3 Modalidade ........................................................170

5.3.1.1.2 Ideologia e efeitos sociais da narrativa......................... 169

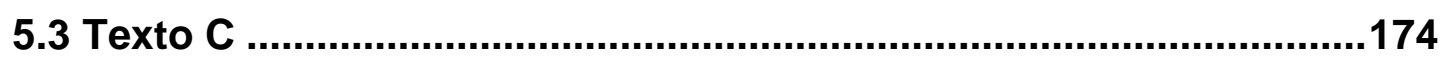

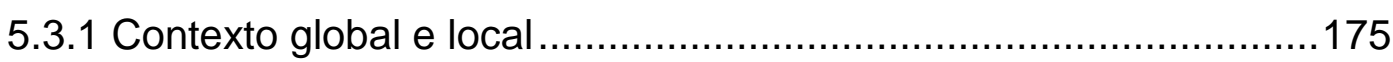

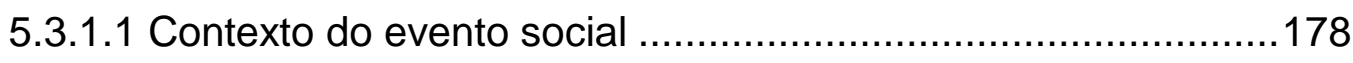

5.3.1.1.1 Análise do Texto C........................................................181

5.3.1.1.1.1 Gênero global e local............................................182

5.3.1.1.1.2 Representação narrativa .........................................183

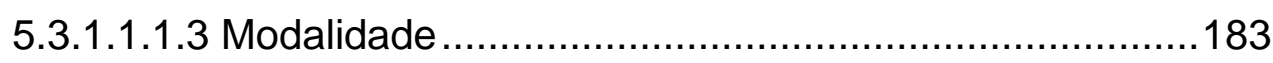

5.3.1.1.2 Ideologia e efeitos sociais da narrativa ............................184

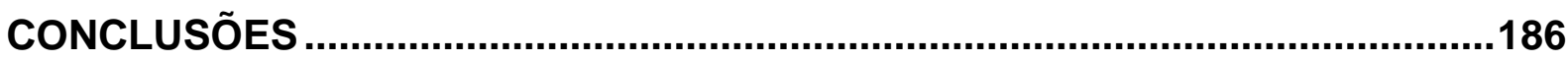


REFERÊNCIAS

192

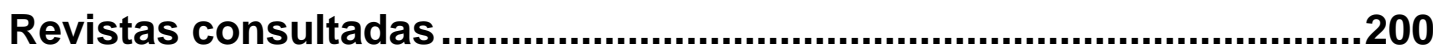

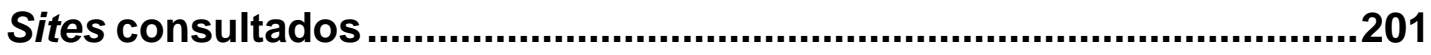




\section{INTRODUÇÃO}

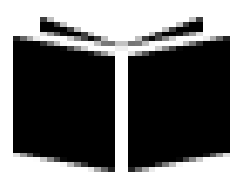

O narrar é uma experiência universal significativa, uma prática mimética da ação humana e de representação verossímil das situações e dos eventos do mundo, destinada a produzir significados potencialmente constitutivos da realidade. Por isso, os homens narraram, narram e continuarão narrando de forma imaginária ou realisticamente consonantes com os contextos sociais em que interagem.

Como fruto da imaginação humana, são literárias as narrativas que nos envolvem ao longo dos seus desenredos, suscitando reflexões e despertando sentimentos renovadores. Como representação plural e ininterrupta das situações e dos eventos sociais, são jornalísticas as narrativas - objeto de nosso estudo científico -, que retratam simbolicamente os fatos e os acontecimentos da realidade.

Desde a época em que os acontecimentos do mundo sócio-políticoeconômico eram narrados em página preto e branco ${ }^{1}$ passando pelo tempo em que as formas tipográficas extensivas das vozes e das mentes dominantes eram as preferidas socialmente, até a atualidade, quando a comunicação midiática monomodal é revertida para dar lugar aos textos multimodais ${ }^{2}$ as narrativas midiáticas multimodais ganham espaço nas páginas dos impressos, de modo tal que a sociedade contemporânea é rapidamente levada a ver o mundo social tal como semioticamente representado. Todavia, diferentemente das épocas anteriores, as narrativas midiáticas multimodais ${ }^{3}$ que hoje ocupam espaço privilegiado nos meios de comunicação de massa tornaram-se formas estéticas impressionantemente envolventes e persuasivas.

\footnotetext{
${ }^{1}$ Os textos monomodais são elaborados com recursos linguísticos exclusivos e com ilustrações graficamente uniformes e densas (VAN LEEUWEN, 2005).

2 Os textos multimodais combinam recursos semióticos das diferentes modalidades da linguagem em um todo composicional coerente e dinâmico (VAN LEEUWEN, 2005).

${ }^{3}$ Narrativas midiáticas multimodais são textos jornalísticos, tais como reportagens e notícias, que representam os fatos e acontecimentos do mundo real por meio dos diferentes modos da linguagem.
} 
Uma breve comparação entre as narrativas monomodais veiculadas pela mídia impressa do passado (Figuras 1, 2, 3 e 4), e as novas narrativas (Figuras 5, 6, 7 e 8), mostra a mudança processada nas formas midiáticas às quais a opinião pública atribui credibilidade e valor social.

Figura 1 - A Gazeta de Londres

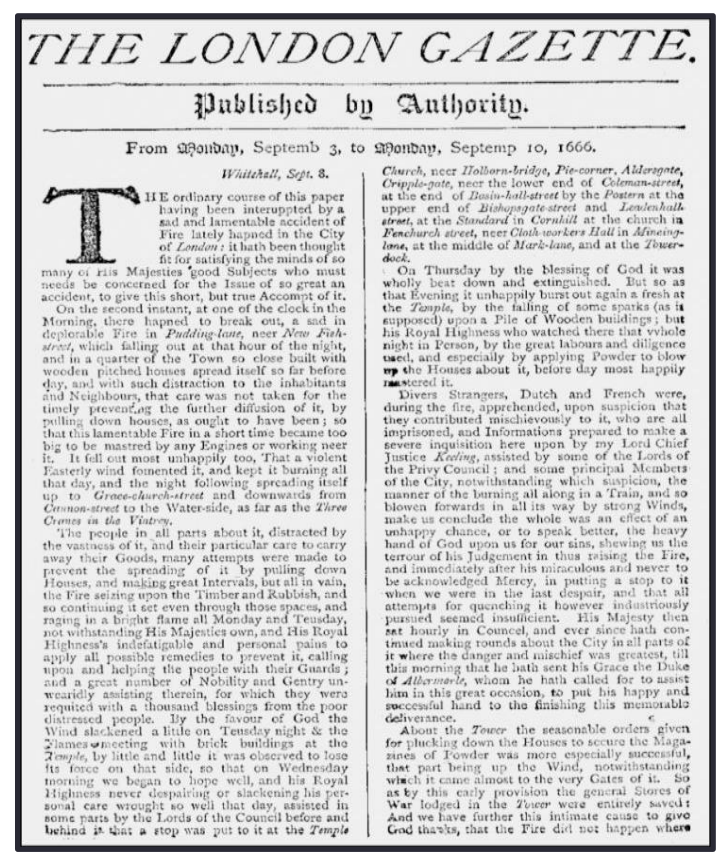

Figura 2 - Correio Braziliense

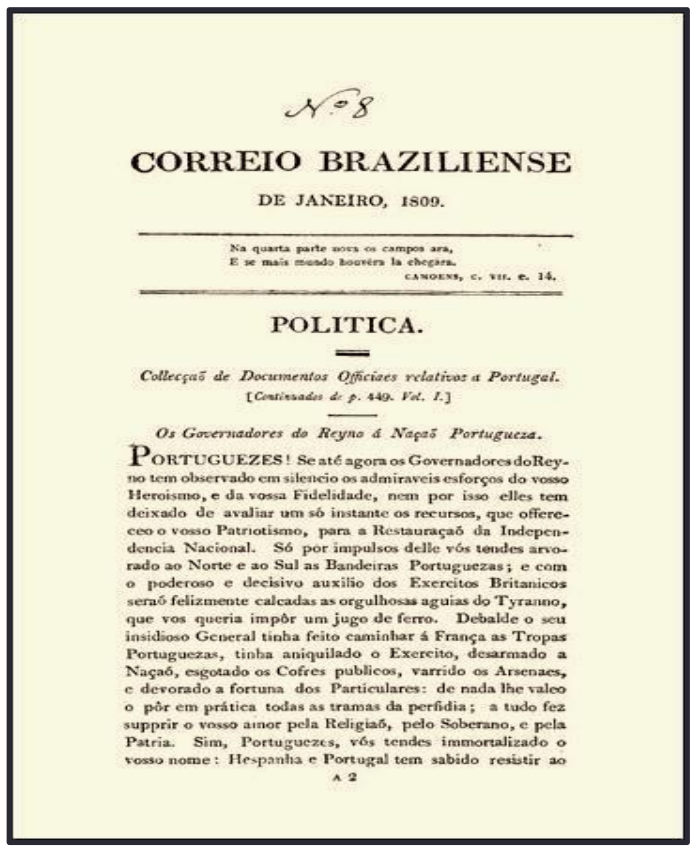

Fonte: <http://super.abril.com.br/blogs/superlistas/as-7-publicacoes-impressas-mais-antigasdo-brasil-e-do-mundo>.

Figura 3 - Revista Scot

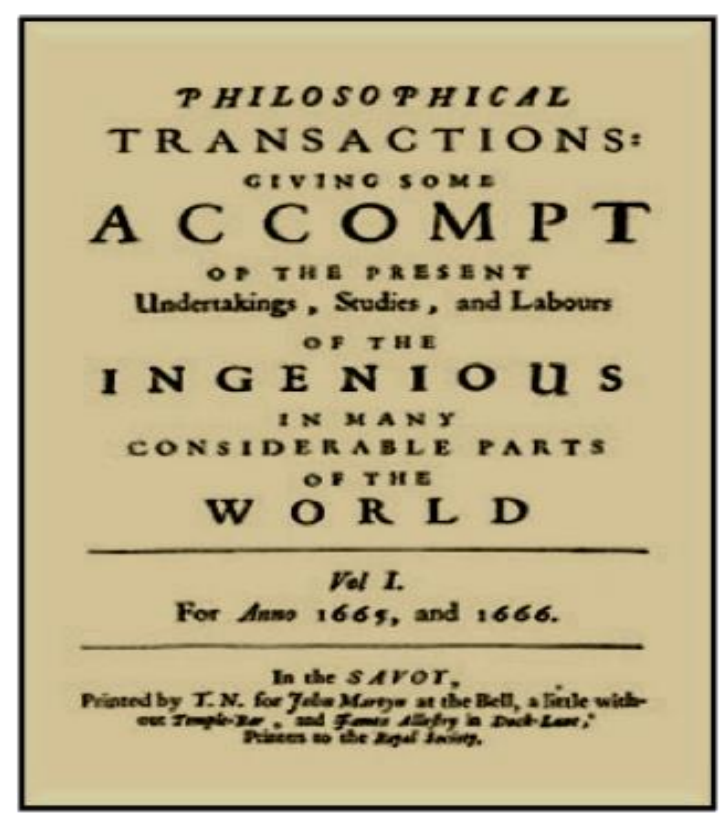

Fonte: $<$ http//super.abril.com.br/blogs/>.
Figura 4 - Revista O Cruzeiro

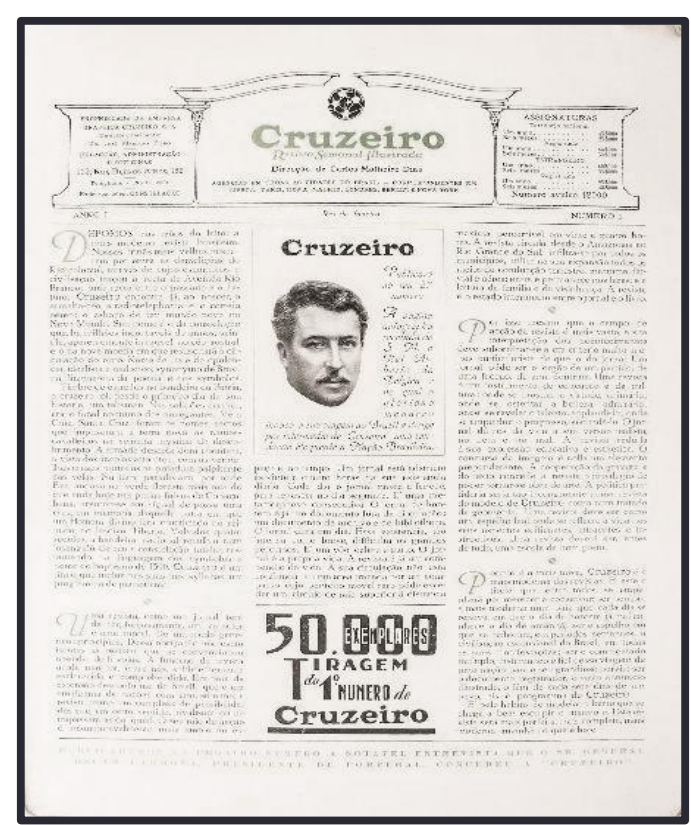

Fonte: <http://www.antonioferreira.lel.br>. 
Figura 5 - Jornais

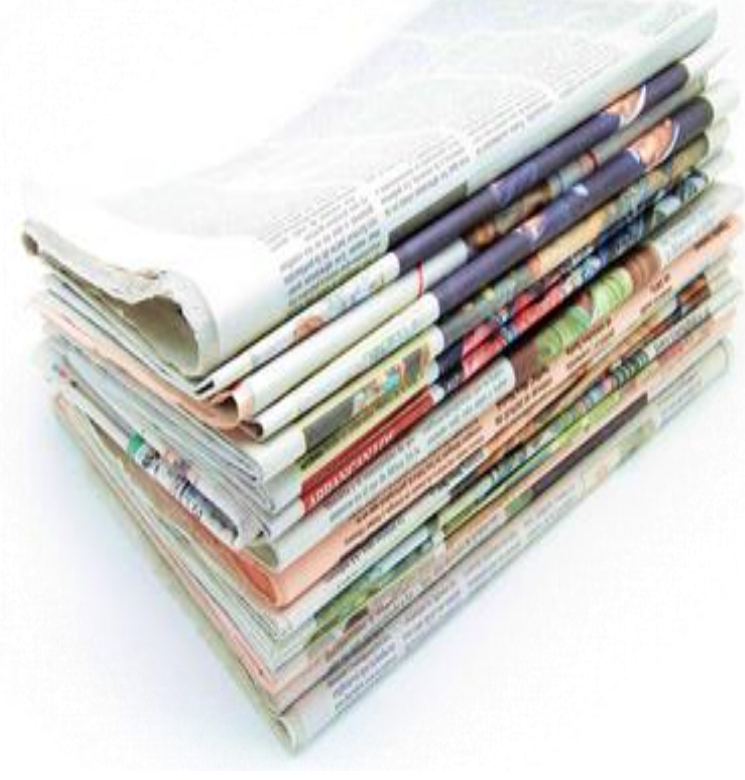

Fonte: Banco de imagens Fotolia.

Figura 7 - Televisão

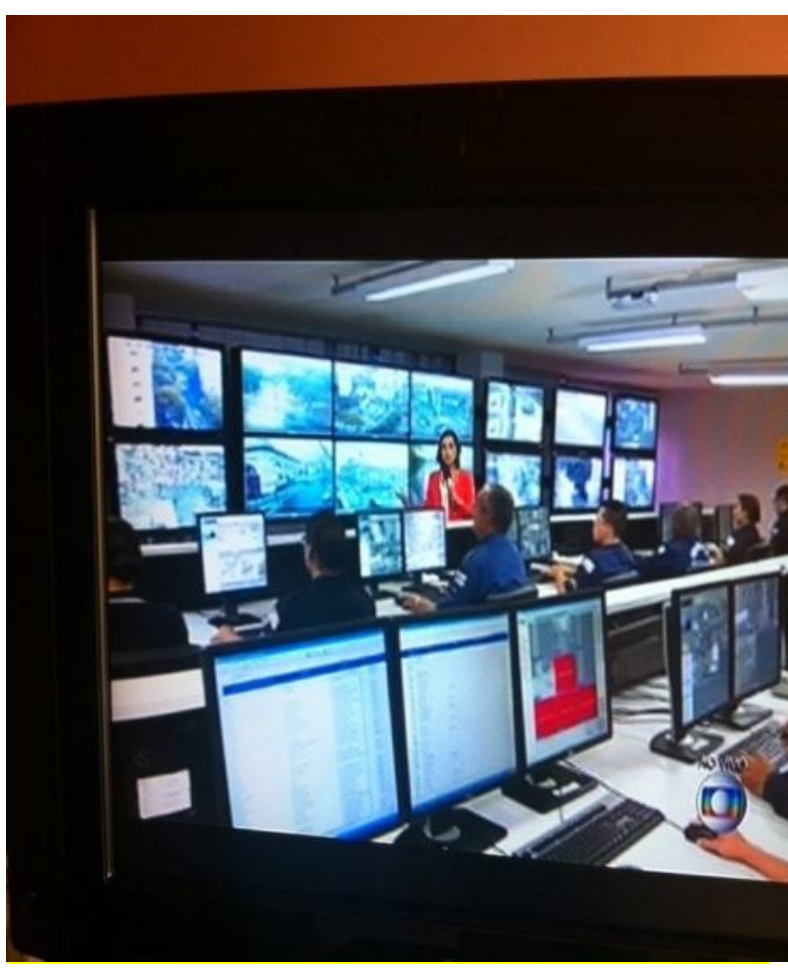

Fonte: Canal da Globo News, 19 h32.
Figura 6 - Revistas

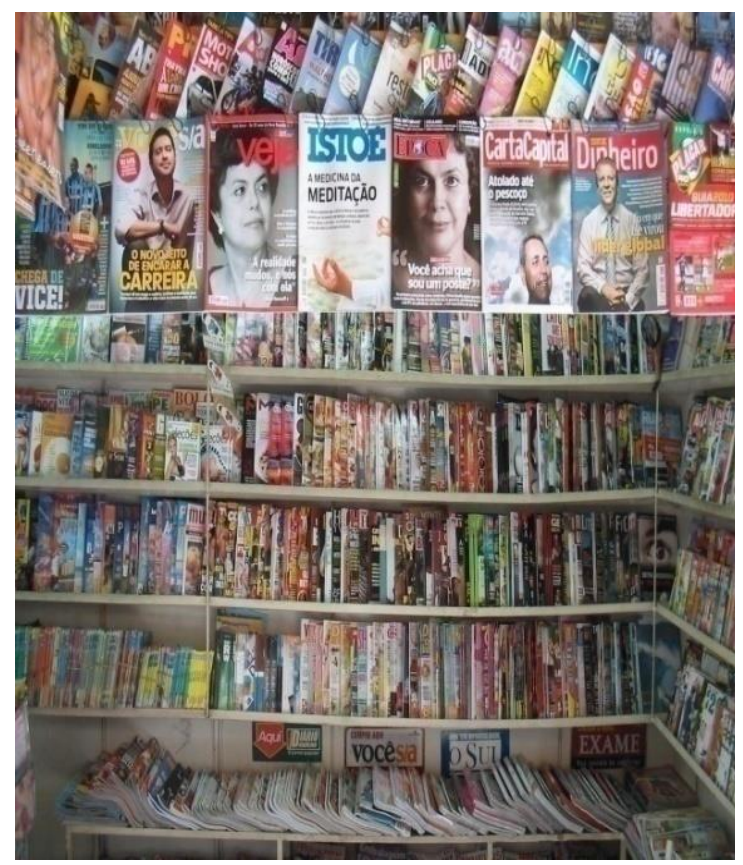

Fonte: <www.google.com.br/search?q=revista>.

Figura 8 - Internet

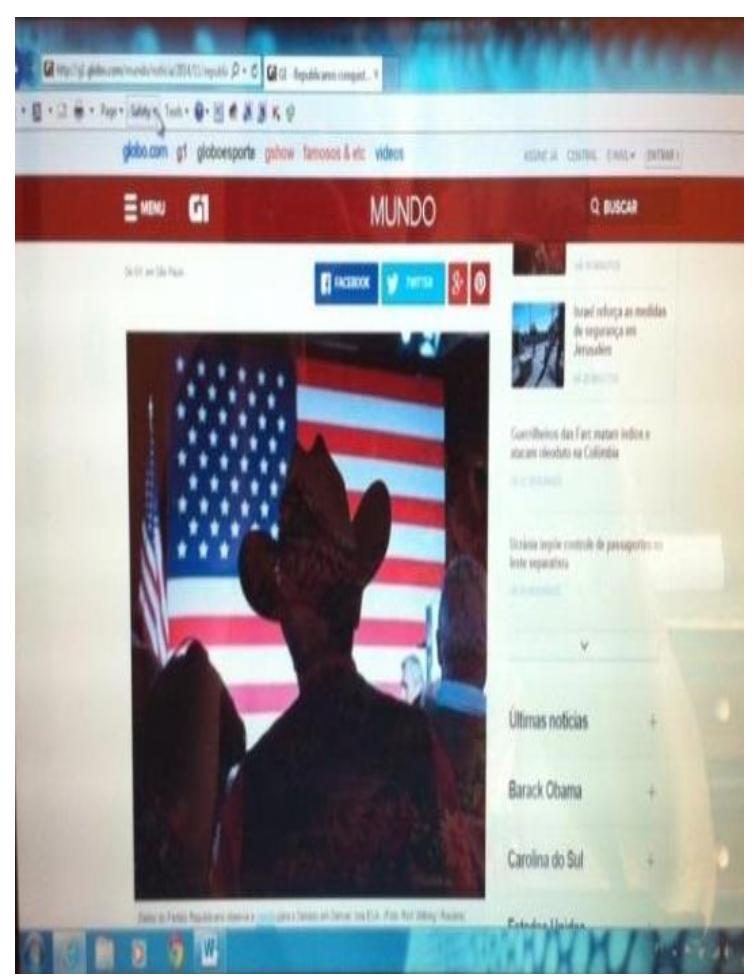

Fonte: <http//: www.g1.com.br>. 
A associação de cuida do jornalismo no mundo calcula que nos dias de hoje 900 milhões de pessoas no mundo leem jornais e revistas diariamente. Isso ocorre devido à dinamicidade da sociedade contemporânea ao desejo individual de consumo rápido. Como consequência, as sociedades são cada vez mais representadas por narrativas que transcendem diferentes redes de comunicação tecnológicas em diferentes escalas. Mas as narrativas multimodais da mídia contemporânea não são reproduções neutras da realidade como de senso comum. São formas simbólicas ideológicas capazes de ativar informações armazenadas na memória episódica dos seus receptores de modo a satisfazer aos interesses das instituições de onde elas saem. Isso implica considerar que a percepção social acerca das culturas, das organizações públicas e privadas, das pessoas e dos objetos do mundo social é construída semioticamente.

Em suas modalidades de expressão oral e escrita, a linguagem sempre desempenhou e desempenha papel de importância central à comunicação humana nos mais distintos contextos da vida em sociedade. A oralidade foi e continua sendo o principal objeto de apreensão e de representação das experiências humanas e de diálogo entre os sujeitos presentes em contextos de interação face a face, em virtude da espontaneidade e da flexibilidade de seu uso. A escrita, modalidade linguística que mantém uma relação estreita e reflexiva com a oralidade, foi escolhida para organizar, fixar e compartilhar a experiência social e institucional, em contextos sociais mais estruturados e de dimensões temporais e espaciais distintas, por seu modo eloquente, essencial para permear as transformações da vida em sociedade. A linguagem visual que, desde os tempos mais remotos, significou e ressignificou o mundo e seus objetos em diferentes dimensões espaciais integra-se, de modo cada vez mais notável, às formas comunicativas mediadas pelos novos meios de comunicação por sua expressividade e rapidez na compreensão dos significados/sentidos articulados.

A função das empresas e dos profissionais da comunicação é informar com neutralidade, imparcialidade e precisão, os acontecimentos retratados após um exame atento e minucioso dos acontecimentos reais. A orientação recebida pela mídia é a de que seja, fundamentalmente, a porta voz de todos os grupos organizados da sociedade, entretanto, na medida em que aqueles que se apropriam 
dos meios de comunicação social determinam o que deve ser narrado, o direito de comunicar-se e de opinar torna-se restrito a poucos.

A presente pesquisa qualitativa nasce da inquietação despertada pela percepção de um senso que toma o poder simbólico exercido pelos meios de comunicação como algo absoluto, incontestável e definitivo. Nasce, também, da percepção de que problemas sociais indesejáveis são, em parte, mantidos pela prática econômica política da mídia global. Nasce, ainda, da constatação de que o tempo das narrativas é difuso e desordenado e da suposição de que os efeitos de sentido evocados pela estética de seus modos resultam da aplicação planejada de recursos semióticos disponíveis.

Concentra-se na área da Linguagem e Sociedade, precisamente em uma linha de orientação crítica transdisciplinar - Discursos, Representação Sociais e Textos - na qual reside a concepção basilar de que o discurso e as semioses são elementos das práticas sociais, intrinsecamente relacionadas às estruturas sociais, que, juntamente com outros elementos dessas práticas, contribuem para as mudanças e para as transformações da sociedade contemporânea.

Por entender que as narrativas da mídia, voz mais eloquente da globalização, podem ser veiculadas com o propósito de satisfazer interesses hegemônicos, a pesquisa busca analisar os modos de construção de sentido ideológico de narrativas multimodais difundidas pela mídia de massa e os efeitos sociais que elas produzem sobre a vida em sociedade.

Defende a tese de que as narrativas midiáticas multimodais são um gênero de texto especializado produzido sob o controle de modelos de contextos, em cujo formato tecnológico os elementos são representados e modalizados para ter efeitos de sentido sobre as condutas sociais; portanto, não são (re)produções fiéis da realidade como é do senso comum. Para defendê-la, a investigação ancora-se nas seguintes questões metodológicas: 
1. como as narrativas multimodais difundidas pela mídia global são estrategicamente organizadas para ter efeitos sociais?

2. de que modo os participantes das estruturas narrativas midiáticas são representados ideologicamente?

3. como são modalizadas as narrativas midiáticas multimodais manipuladas pela mídia impressa?

A pesquisa linguística baseia-se na Teoria Semiótica Social da Multimodalidade (KRESS e VAN LEEUWEN, 2006), (VAN LEEUWEN, 2005, 2008), (MACHIN e VAN LEEUWEN, 2007), na Análise de Discurso Crítica (FAIRCLOUGH, 2001, 2003, 2006, 2011) e na Teoria Sociocognitiva do Contexto, teorias sociais da linguagem que mantêm relações dialéticas com ciências sociais e comunicativas, em especial, com a Teoria da Ideologia (THOMPSON, 2011, 2012) e com os temas sociais (CASTELLS, 2003, 2009), (GIDDENS, 1999, 2002); (BAUMAN 1999, 2010), (MCQUAIL, 2013).

As tensões, dúvidas e hesitações decorrentes de investigações dessa natureza encontram em Bauer e Gaskell (2000), em Flick (2006) e em Denzin (2006) orientações metodológicas consistentes. Com efeito, a pesquisa utiliza metodologias analíticas de natureza transdisciplinar, as quais trabalham com categorias discursivas e semióticas sistematizadas pela Análise de Discurso Crítica e pela Multimodalidade.

Uma série de textos extraídos de impressos - jornais e revistas nacionais e internacionais - compõe uma amostra representativa de dados destinados à análise. Esses textos são narrativas multimodais, predominantemente, selecionadas de capas e de páginas de revistas de alcance global e de alto consumo. Vários dessas narrativas são utilizadas para demonstrar os argumentos expostos ao longo do estudo, mas somente quatro narrativas multimodais são efetivamente analisadas três da revista brasileira Veja e uma narrativa multimodal da revista inglesa The Economist. A revista Veja foi escolhida por se alinhar a ideias econômicas neoliberalistas e por ser a quarta revista com maior tiragem no mundo. A revista inglesa foi escolhida por ser alcance global, ter um público alvo qualificado e 
influente e estimular a privatização, a desregulamentação e a liberalização. As narrativas analisadas focalizam tema de mercado e, principalmente, temas de política, como a democracia.

A tese compõe-se de cinco capítulos. O primeiro capítulo aborda os contextos globais que controlam e regulam a produção de narrativas mediadas pela mídia à luz de novas perspectivas teóricas, demonstrando a macroestrutura de um modelo de editorial político cujo tema tem sido coberto pela mídia nacional.

O segundo capítulo enfoca os contextos sócio-históricos e institucionais da mídia impressa e os modos de operação da ideologia nas formas simbólicas contemporâneas, identificando o uso estratégico de alguns desses modos em representações narrativas midiáticas bem como focaliza os efeitos sociais causados pelo gênero textual.

Dada a orientação multidisciplinar definida pelo triângulo discurso - cognição - sociedade e pelo entendimento de que as unidades semânticas subjacentes às formas multimodais incorporam mecanismos cognitivos e ideológicos, o terceiro capítulo explicita as bases teóricas que fundamentam a pesquisa, detalhando categorias de análise sistematizadas pela Multimodalidade (MACHIN e VAN LEEUWEN, 2007), (KRESS e VAN LEEUWEN, 1996, 2006) e pela Análise de Discurso Crítica (FAIRCLOUGH, 2003), as quais são aplicadas nos dados selecionados.

O quarto capítulo refere-se ao caminho metodológico adotado para o desenvolvimento do estudo, o qual inclui o delineamento da pesquisa, informações acerca dos dados de análise, explicações sobre as metodologias apropriadas aos objetivos da pesquisa e as categorias de análise aplicáveis aos dados.

No quinto capítulo, são feitas análises semióticas críticas de quatro narrativas multimodais - três da revista Veja e uma da revista inglesa The Economist - com o objetivo de defender a tese de que as narrativas midiáticas multimodais são um gênero especializado de texto produzido sob o controle de modelos de contextos globais e locais persuasivos, em cujo formato tecnológico os elementos são representados e modalizados de modo a produzir efeitos de sentido sobre as condutas sociais. Reflexões sobre os efeitos sociais derivados dos modos de 
construção de sentido dos textos analisados são seguidas de uma conclusão sobre a análise realizada. O último capítulo faz considerações sobre o estudo, finalizandoo com sugestões para futuras pesquisas. 


\section{CAPÍTULO 1}

\section{CONTEXTOS GLOBAIS E NARRATIVAS DA MÍDIA CONTEMPORÂNEA}

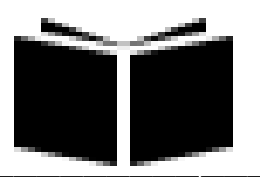

Orientado pelo triângulo sociedade, cognição e discurso, em que a cognição é vista como o que reúne um conjunto de conhecimentos que definem a memória social, este estudo, em seu primeiro capítulo, apresenta-se com dois objetivos. O primeiro é explicitar os mais amplos contextos que, indiretamente, regulam e controlam a produção das narrativas mediadas pelos meios de comunicação de massa, por meio das práticas das quais o discurso e as semioses são elementos relevantes: a sociedade de consumo, a comunicação globalizada, os EstadosNação, a mídia e as suas formas de mediação e o poder da comunicação de redes. O segundo objetivo é abordar a narrativa midiática como componente fundamental da grande mídia ${ }^{4}$, a qual representa evento sociopolítico, à luz de perspectivas sociais críticas relacionadas, destacando a macroestrutura do texto midiático impresso publicado em primeira página de jornal de circulação nacional.

\subsection{Contextos globais}

A definição de contexto em nossa pesquisa sociossemiótica crítica toma como base a Teoria Sociocognitiva de Contexto (VAN DIJK, 2012), segundo a qual contextos são modelos mentais únicos e subjetivos das propriedades relevantes das situações e dos eventos sociocomunicativos armazenados na memória dos participantes. Mas, os modelos de contexto, fruto da capacidade humana de representar mentalmente

\footnotetext{
${ }^{4}$ Grande mídia é a expressão empregada para designar os principais veículos de comunicação social, considerando tanto os meios tradicionais de divulgação da informação (imprensa, rádio, TV) quanto às novas tecnologias (conteúdos que se transferem pela rede). "Globalmente, a grande mídia é representada pelos sete principais conglomerados transnacionais da indústria da informação e do entretenimento: AOL- Time Warner, Viacom, Sony, News Corporation, Disney, Vivendi Universal, Globo, Associados e Bertelsmann". Disponível em: <http://pt.wikipedia.org/wiki/Grande_midia>. Acesso em: 6 dez. 2014.
} 
estruturas e situações sociais, dependem da seleção de modelos mentais relevantes, dotados de propriedades que permitem controlar a produção do discurso.

Nessa perspectiva, os modelos de contexto representados na memoria social organizam nossas experiências cotidianas em esquemas úteis à compreensão do discurso e à recuperação de nossos modelos mentais antigos, de maneira que são eles que formam a base dos gêneros discursivos, das representações sociais e dos modos como o conhecimento é administrado para a comunicação. Isso significa que a memória social é definida por modelos de contexto que, uma vez ativados de forma relevante pelo discurso guiam a cognição humana.

\subsubsection{Sociedade de consumo}

A sociedade contemporânea caracteriza-se pela preeminência de um sistema constituído por relações hegemônicas que o instituem e o estruturam: o capitalismo. São poucos os lugares no mundo pós-moderno não afetados por esse modelo de contexto. Todavia, a visão comum acerca do capitalismo é ilusória, particularmente com relação à classe social dominante, ao imaginar que esta assegura aos trabalhadores condições dignificantes e satisfatórias (BAUMAN, 1999).

O capitalismo é um sistema econômico explorador. O aumento da riqueza da classe capitalista, o que a mantém como tal, está relacionado aos resultados decorrentes dos esforços da produção e da aquisição dos bens circulantes destinados ao consumo. Nesse modelo de contexto, as diferenças materiais são as que têm mais efeitos sobre as subjetividades e sobre as posições sociais, mas como o modelo capitalista não é permanente, a classe dominante esconde a verdadeira natureza dele, para se beneficiar de sua relação com os meios de produção.

De acordo com Fairclough (1995, p. 45), as empresas e as organizações capitalistas distinguem-se pelo tipo de propriedade, pela quantidade dos recursos materiais que detêm e pelas regras, esquemas e convenções que governam o uso dos recursos aplicados na produção de bens de consumo, as quais dirigem hierarquicamente os indivíduos para os quais designam uma trajetória de vida. Determinados tipos de propriedade, sobretudo os grandes conglomerados, cujos negócios são a indústria da cultura, exercem importante influência social via as 
formas mediadas pelos meios de comunicação de massa. Ao permitir que os meios de comunicação sejam totalmente integrados aos interesses de propriedade na economia nacional e internacional, essa indústria intensifica sua associação com os interesses das classes capitalistas. Com efeito, associações manifestadas de várias maneiras incluem os modos pelos quais as organizações de mídia se estruturam para garantir que as vozes dominantes estabeleçam o poder político e social e estejam presentes em um ethos ${ }^{5}$ localmente gerado por interesses pró-capitalistas.

Thompson (2012), explica que no processo de luta pelo poder econômico e político, os meios de comunicação são utilizados como um tipo de atividade social que envolve a produção/difusão e a recepção das formas simbólicas ${ }^{6}$ como chave de reprodução das relações sociais estruturantes do sistema capitalista. Em certa medida, essas formas se tornam um processo criativo que envolve um grau de seletividade e de julgamento no qual regras e esquemas podem ser modificados no momento de aplicação dos recursos disponíveis.

A (re)produtibilidade de semioses ideológicas pelos meios de comunicação tornou-se uma característica básica da exploração comercial nas sociedades contemporâneas porque os objetivos e os interesses das grandes organizações para o exercício de poder dependem do consumo para serem alcançados. Mesmo que muitas formas de ação e de interação sejam produzidas fora de instituições capitalistas específicas, elas são afetadas porque nelas estão implementadas as condições dos campos hegemônicos de interação dentro dos quais elas têm lugar.

Richardson (2007, p.4) afirma que, para produtos informativos - jornais e revistas de propriedade particular - serem vendidos, eles devem se apresentar congruentes com os bens e os produtos do mercado capitalista. Sejam genuínos, sejam supostos, os produtos de consumo passaram a atrair e a recrutar consumidores ao seu valor de investimento, consequentemente, a condicionar a autoestima desses indivíduos.

\footnotetext{
${ }^{5}$ Empregado pela Análise de Discurso Crítica, o termo ethos diz respeito ao processo de modelagem de identidades o qual é perpassado pelo discurso (representações sociais) e pelo gênero. Pode ser compreendido como um comportamento que objetiva construir identidades para o processo de comunicação. $\mathrm{O}$ ethos pode manifestar-se socialmente, tanto pela expressão corporal quanto pela forma de apresentação profissional: ethos cientista, ethos médico; ethos professor etc. (FAIRCLOUGH, 2001, p. 207-209).

${ }^{6}$ Formas simbólicas são ações e expressões significativas de manifestações verbais e não verbais, de textos e artefatos de vários tipos produzidos e recebidos por indivíduos situados no mundo sóciohistórico (THOMPSON, 2011).
} 
Nesse sentido, Bauman (1999) acentua que os cidadãos da nossa época são constantemente levados a crer que a única escolha aprovada de maneira incondicional é a aquisição dos produtos de consumo. Mesmo a arte, o melhor meio de desenvolvimento da percepção, de julgamento e de reflexão, é tomada como produto cultural de consumo. É como o autor esclarece:

A maneira como a sociedade atual molda seus membros é ditada primeiro e acima de tudo pelo dever de desempenhar o papel de consumidor. A norma que nossa sociedade coloca aos seus membros é a capacidade e vontade de desempenhar esse papel. (...) o dilema sobre o qual mais se cogita hoje é se é necessário consumir para viver ou para poder consumir (BAUMAN, 1999, p. 88.)

Para o sociólogo, o que contribui para o perfil do consumidor do nosso tempo é uma forte ressonância da lógica da economia orientada ao consumismo pelo uso da tecnologia compressora do tempo e pelo espetáculo das formas simbólicas. Os produtos de consumo atraem os consumidores sem que deles sejam exigidos o aprendizado e o desenvolvimento de quaisquer habilidades, mas a satisfação é instantânea, pois termina logo que o produto é adquirido e consumido. Assim, aquilo que atrai e estimula o consumidor a agir é, ao mesmo tempo, o que o repele e o admoesta a fugir. Uma sociedade que cria desejos e insatisfações encontra, na rejeição a todas as opções culturais, a estratégia alternativa para a sua existência. Adaptar-se à sociedade capitalista significa seguir os preceitos de um contexto cujo modelo é voltado para o consumo para todos os fins e propósito sociais e propósitos. A aprovação do consumidor tornou-se precondição para participar das redes sociais tecnológicas usadas nas redes de comunicação pelas relações capitalistas. Em meio às inovações perturbadoras, as relações tornam-se fúteis e manipuláveis. Ainda para Bauman (1999, p. 91), a perdição da sociedade de consumo está na excessiva preocupação com a negociação dos bens. Para aumentar sua capacidade de consumo, os consumidores não devem ter descanso. Precisam ser mantidos acordados e continuamente expostos a novas tentações. $O$ impacto provocado pelos significados/sentidos das narrativas midiáticas, cujas manchetes circulam como produtos informativos controlados pelo modelo capitalista reflete o interesse pela comodificação do consumidor à semelhança do mercado que encontra no maior consumo, a satisfação da classe que indiretamente o fabrica. 
Fairclough e Fairclough (2012) explicam que a contradição inerente do modelo capitalismo leva a desequilíbrios e, por conseguinte, à crise financeira: a perda dos saldos necessários ao funcionamento do sistema. Mas além desse aspecto objetivo, a crise causada pela instabilidade do capitalismo cria o espaço para estratégias de intervenção que redirecionam o curso dos eventos e daqueles que lhes estão associados, incluindo imaginários econômicos e políticos, e para estratégias resultantes das lutas discursivas que impeçam o exercício do poder. A análise de narrativas reais ou imaginárias, de acordo com os autores, deve considerar que os argumentos práticos nelas incorporados influenciam processos de tomada de decisão, como premissas para a ação.

Em entrevista concedida à televisão espanhola, Castells (2013) assevera que o abismo que separa as instituições capitalistas das pessoas acontece porque as elites financeiras que detêm o poder econômico e que mantêm o poder político estabeleceram um sistema no qual, em vez de emprestar para produzir, vendem dinheiro para criar dinheiro artificial e montar pirâmides fictícias em âmbito global.

De acordo com o sociólogo político, se a crise de confiança gerada em todo o mundo continuar e se agravar, as relações na sociedade podem se romper. Conclui o autor, que as novas redes sociais da internet têm aberto as janelas para a reflexividade e que, na medida em que a opinião pública é diferentemente construída nas redes de comunicação por mentes individuais, as redes de comunicação vão operar com a condição de optar por construir redes para a vida.

\subsubsection{Comunicação globalizada}

Fairclough (2006) explica que a globalização é um fenômeno que envolve um conjunto de processos altamente complexos, multifacetados e parcialmente autônomos em que aspectos econômicos, políticos, sociais e culturais são materializados. No complexo fluxo da comunicação globalizada, o uso do discurso é uma das facetas da globalização que não passa despercebido. São destacados pelo autor três importantes aspectos relacionados ao fenômeno propriamente dito da globalização. O primeiro compreende as redes de comunicação que atravessam fronteiras e que funcionam como formas especializadas nas (inter)ações transnacionais e interregionais. O segundo envolve propriamente um discurso 
constituídos de formas narrativas e argumentativas que contribui para representar os processos reais da globalização. O terceiro aspecto relacionado à globalização diz respeito às imagens globalistas com potencial semântico para dar uma forma particular aos processos comunicativos.

A comunicação globalizada teve origem em meados do século XIX, quando os materiais impressos eram transportados para as distâncias além das fronteiras de estados, mas foi no curso do século XX que o fluxo internacional de informação e de comunicação assumiu forma complexa e multifacetada. As agências de notícias internacionais europeias e as redes de comunicação estabeleceram o começo de um sistema global de processamento da comunicação e da informação capaz de transmitir mensagens de tal maneira que indivíduos situados a distância e em contextos particulares puderam ter acesso a elas. A comunicação globalizada nascida em meio a conflitos derivados da imigração para as cidades, das forças da repressão e das lutas entre nações e desenvolvida de tecnologias eletrônicas não só favoreceu a liberdade política e econômica, mas também a liberdade de expressão (MACQUAIL, 2013, p. 30).

Embora os meios de comunicação tradicionais operados por sistemas com fluxos verticais hierarquizados ainda obedeçam às lógicas de produção de cada meio, o sistema de digitalização levou as mensagens e as tecnologias dos meios analógicos de comunicação a novos ambientes e a novas configurações. O ambiente analógico com a sua lógica e dinâmica não desapareceu, mas passou a conviver com o ambiente digital horizontalizado: de um lado, o sistema (homem-máquina) no qual predominam os esforços de estabilidade; de outro, as novas dinâmicas processuais (sujeito-sujeito) dedicadas à produção dos bens informativos destinados a um mercado consumidor cada vez mais global.

Desde os estudos de MacLuhan (1964), foi possível compreender e constatar que o homem estenderia a sua percepção sobre o mundo por intermédio dos meios de comunicação de massa e que nenhum meio ou tecnologia poderia ser introduzido sem produzir consequências na vida humana. Em seus estudos MacLuhan pressupôs que, com a tecnologia elétrica instantânea, o globo não passaria de uma aldeia, que a natureza, como forma de grandes dimensões, dissolver-se-ia como uma fusão cinematográfica e que o planeta daria a impressão 
de um bairro percorrível. Um material produzido nos EUA ou na Europa, hoje em dia, pode ser facilmente consumido pelo público na Ásia, em vários momentos e em vários lugares do mundo, em virtude do uso generalizado da tecnologia de satélite associado à globalização dos meios de comunicação e à dominação global da América do Norte e dos conglomerados Europeus.

Embora o novo modo de pensar e de fazer criado pela automação tenha possibilitado, de certa forma, a produção inclusiva de massa, ele afetou o consumo e o mercado, transformando o aprendizado em emprego e em fonte dominante de novas riquezas. Isso aponta para o fato de que os meios de comunicação não são neutros, nem meros instrumentos de transmissão de informações.

A comunicação governada por regras e preceitos do capitalismo reproduz formas de controle econômico e político sobre a realidade como se essa fosse um todo indistinto e indiferenciado. Segundo Thompson (2012, p. 208), são vários os fatores que contribuem para essa homogeneidade: a produção de formas simbólicas favoráveis à liberalização do comércio transnacional da comunicação; a interligação das novas tecnologias (satélites, sistema de cabo, métodos digitais de processamento, de mediação e de difusão das informações em diferentes escalas); a distribuição e a circulação dos produtos de informação no mercado global por agências internacionais. A comunicação globalizada (representada pela Figura 8) intensifica-se de forma crescente na pós-modernidade, sobretudo, quando as atividades planejadas, organizadas e coordenadas em escala global acontecem em uma arena global e envolvem significativo grau de reciprocidade e de interdependência. 
Figura 9 - Comunicação globalizada

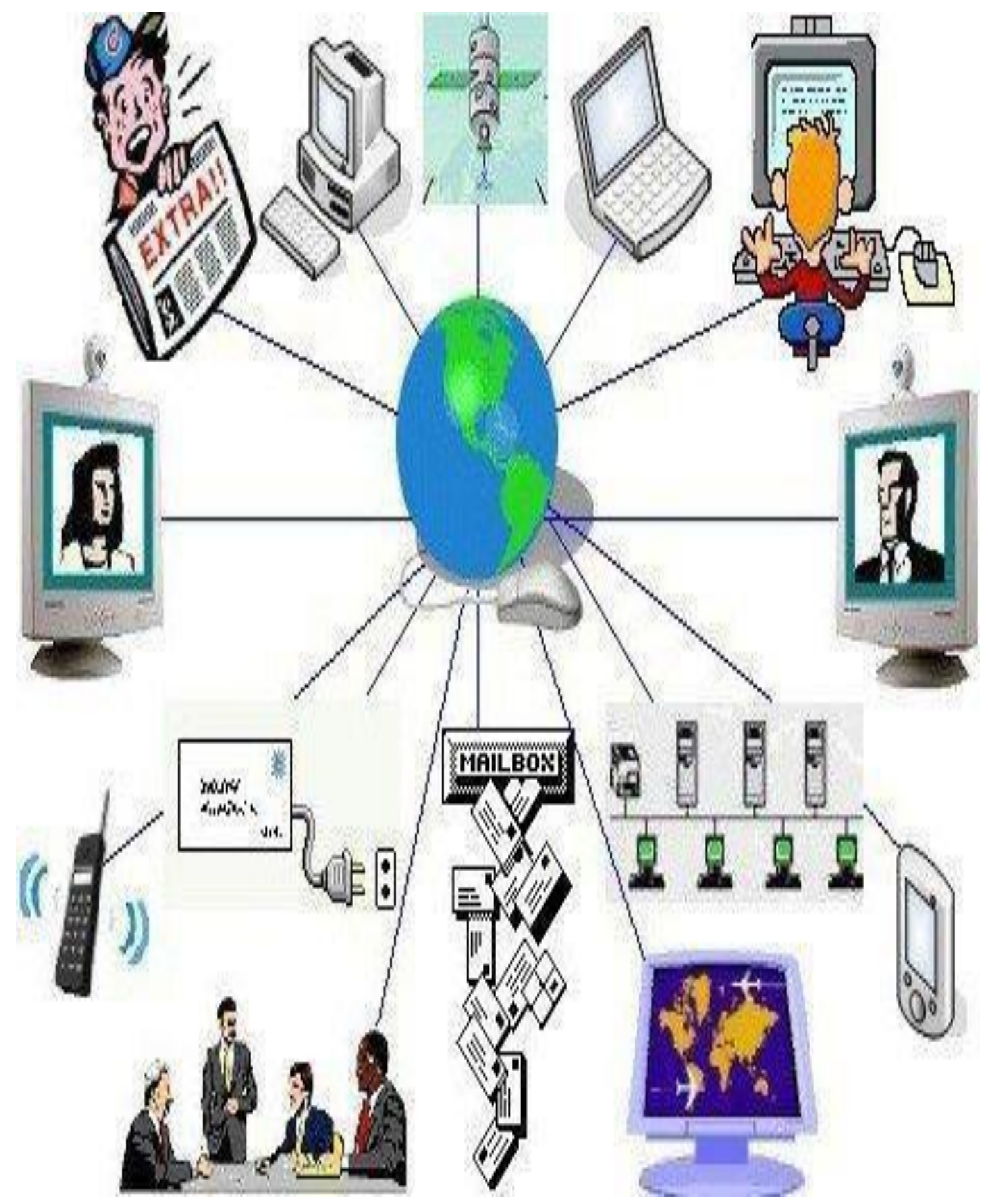

Fonte: <http://professorfaustosimoes.blogspot.com.br/2013/03/globalizacao.html>.

A influência do discurso globalista nas formas midiáticas é crucial porque elas medeiam o caminho entre os domínios públicos e os privados. Isso pode ser observado na representação narrativa publicada na capa da Veja de 28 de agosto de 2013, revista brasileira que aborda assuntos de abrangência nacional e global por meio de um milhão de cópias semanais. 
Figura 10 - Desvalorização do Real

Revista Veja, de 28 de agosto de 2013

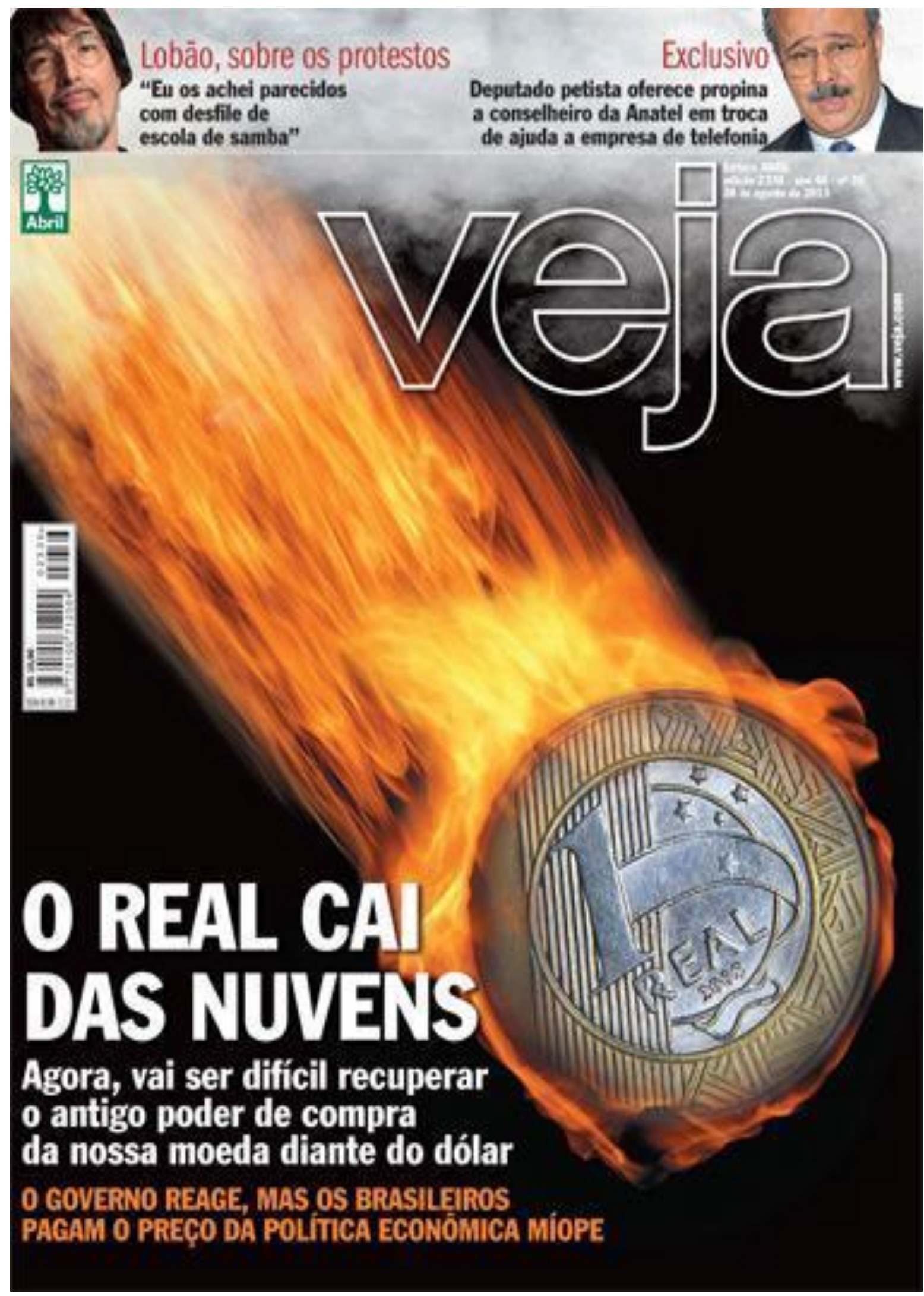

Fonte: Editora Abril, edição 2.336, ano 46, n. 35, capa. 
A representação da queda da moeda brasileira, metaforicamente associada à queda de um cometa, tem impacto em todos os domínios da vida social. Entretanto, a desvalorização do real não denota a sua causa, qual seja: a desaceleração da atividade econômica provocada pelo desequilíbrio na balança comercial, pelo processo de desindustrialização e pela alta do dólar.

A causa da desvalorização da moeda brasileira é atribuída a fatores internos, tais como: à política econômica do Governo Brasileiro e, possivelmente, à 'inércia' e 'à esperteza' do povo brasileiro; o que pode ser observado, respectivamente, por meio do uso da expressão metafórica: "(...) a política econômica míope", e da ironia "O REAL CAI DAS NUVENS", da qual se pode pressupor que os brasileiros esperam ganhar sem trabalhar e que, por isso, recebem como castigo a queda do real. Ainda, o problema econômico parece associado às manifestações populares, ocorridas um mês anterior à publicação da revista (Figura 10) no Brasil. Esta conotação realiza-se por meios do uso gradiente e intenso da cor (amarelo-fogo) que modula a cauda luminosa do cometa ${ }^{7}$ usado para representar a queda do real. O amarelo fogo é a cor que representou o movimento popular, caracterizado como violento, como se observa em páginas de diversos jornais:

Figura 11 - The New York Times

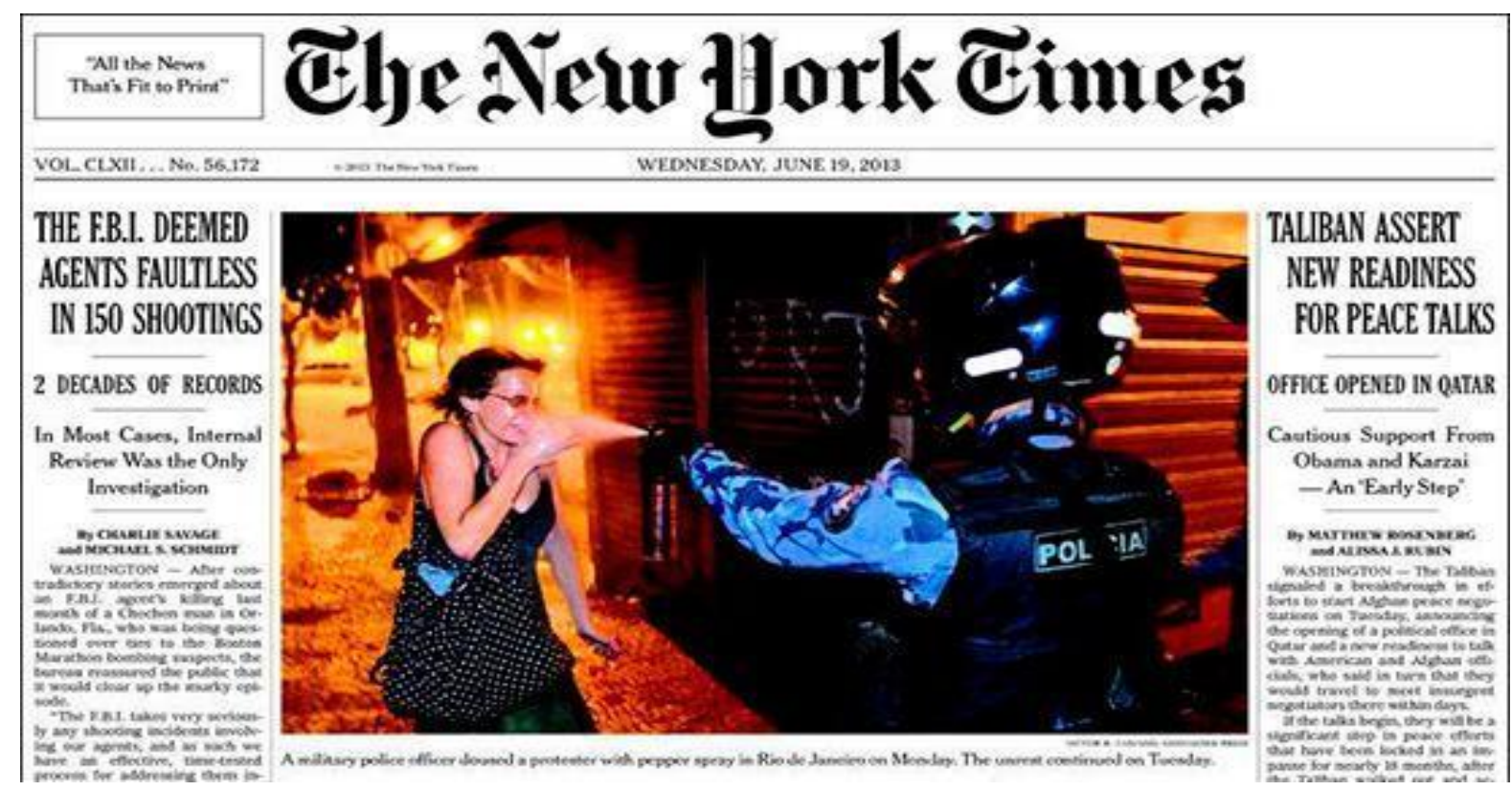

Fonte: <http://agenciabrasil.ebc.com.br>.

${ }^{7}$ Cometa: corpo celeste que se move em torno do sol em trajetória mais excêntrica que a dos planetas e 
Figura 12 - O Estado de S. Paulo

\section{OESTADO DE S. PAULO}

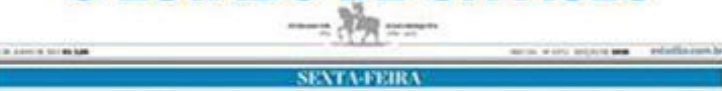

Um milhão vai às ruas, violência cresce e Dilma convoca reunião

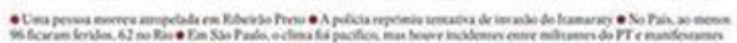

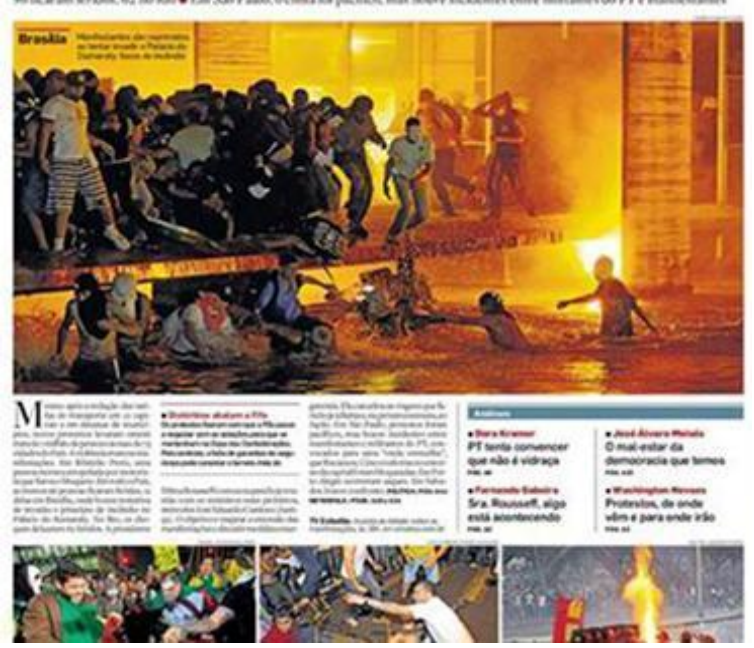

Fonte: <http://www.estadão.com.br>.

Figura 14 - Corriere Della Sera

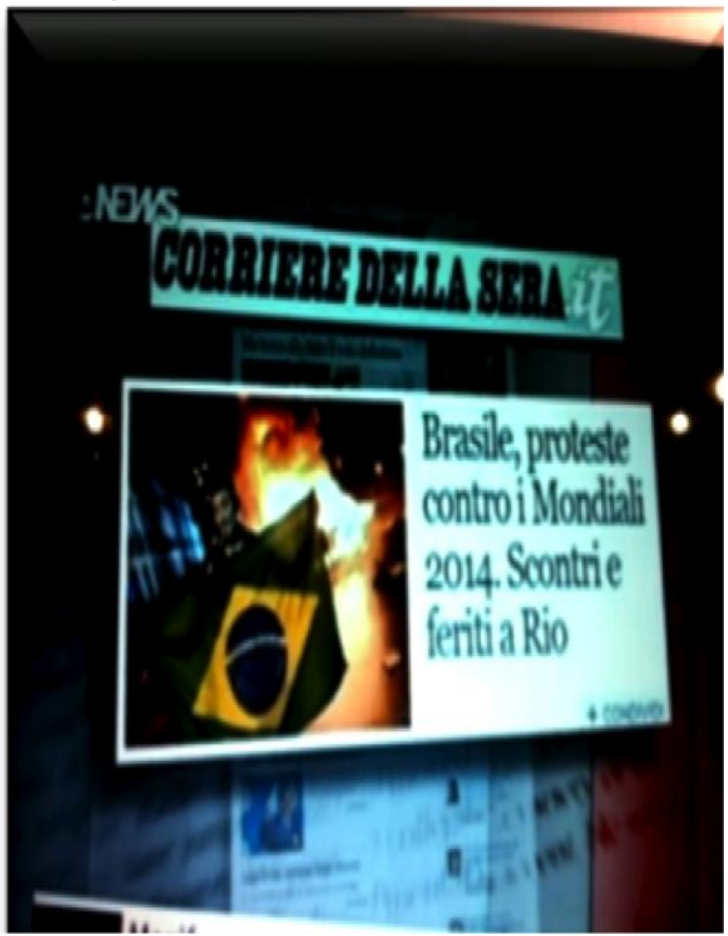

Fonte: <http://agenciabrasil.ebc.com.br>.
Figura 13 - O Globo

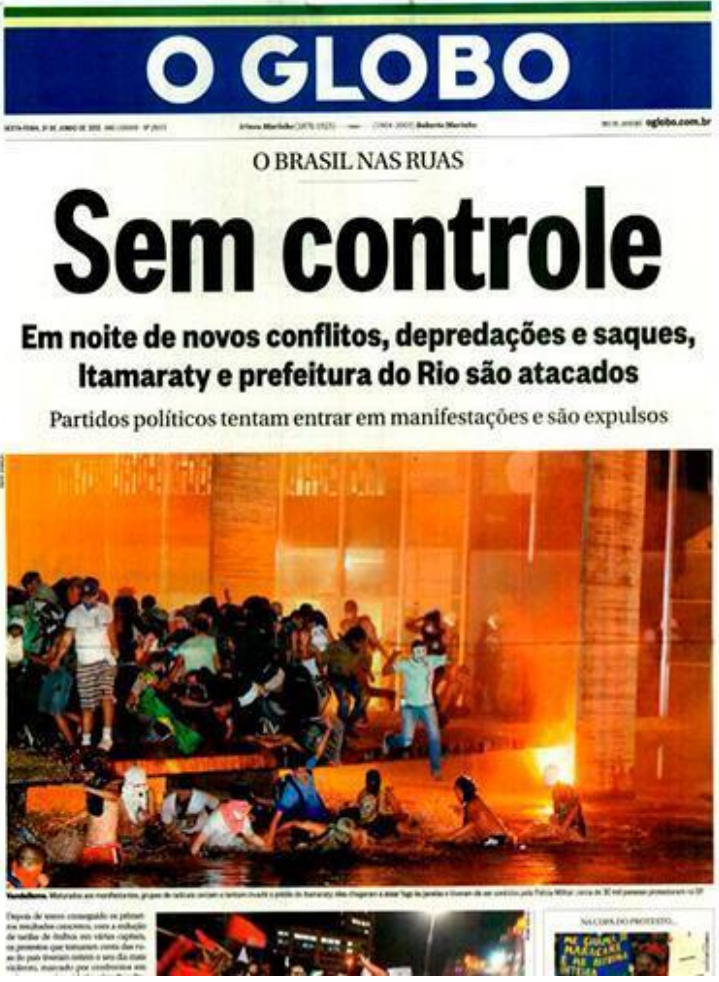

Fonte: <http://www.oglobo.com.br>.

Figura 15 - Le Monde

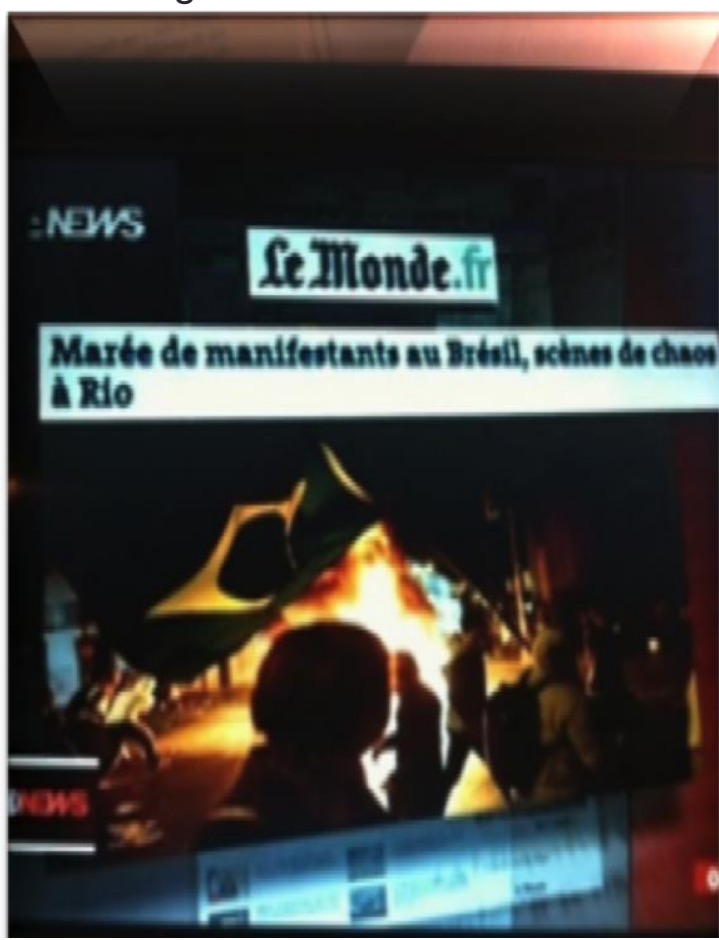

Fonte: <http://agenciabrasil.ebc.com.br>. 
$\mathrm{Na}$ maioria das narrativas jornalísticas, a cor amarelo-fogo foi o recurso semiótico mais usado na retratação dos protestos contra a crise financeira e moral no Brasil. A cor é reutilizada estrategicamente para dissimular os efeitos maléficos da crise financeira mundial que afeta o Brasil. Embora a sociedade brasileira ainda não reconheça explicitamente os efeitos sistêmicos da crise financeira mundial no Brasil, eles são reais. O que contribui para dissimular a causa da crise, para a retomada do controle social pelo mercado global capitalista é cor que modaliza o rastro da queda da moeda brasileira. De forma superficial, observa-se que o uso do marcador de modalidade é uma estratégia da ideologia incorporada na narrativa midiática (Figura 10).

A culpa pela desvalorização da moeda é injustamente atribuída a um movimento popular que deveria ser retratado como uma forma de participação democrática legítima e não como uma forma de violência social. Isso mostra que uma das tarefas da ideologia dominante é impor uma falsa visão da realidade, uma visão que delega às ações desconcertantes, secundárias e contingenciais verdadeiras sanções.

Carey Jewitt (2011) expõe que a comunicação globalizada poderia contribuir bastante para minimizar as consequências do desenvolvimento de uma cultura global em que dois poderosos opostos coexistem - 0 individualismo e 0 comunitarismo -, pois a relação entre os contextos e os textos compostos com recursos de natureza multimodal é dinâmica e importante para as interações sociais. Para isso, a comunicação globalizada, sobretudo, a comunicação de massa deveria dar espaço relevante às práticas socioculturais existentes.

Nesse sentido Vieira (2007, p. 27) enfatiza a importância da construção de uma prática social que possibilite a criação de espaços para diferentes visões de mundo e o uso consciente nas redes de comunicação. Explica a autora que nenhuma linguagem é natural ou semiótica em si mesma, que todas as linguagens são convencionais e resultantes da construção sócio-histórica e cultural. Isso permite compreender a importância da análise de uma série de aspectos, quais sejam: a identificação dos valores e das regras de organização dos sistemas de significado, dos elementos não verbais relacionados às imagens, dos modos de composição dos significados dos textos, dos modos estratégicos da ideologia 
presentes nos textos e dos efeitos de sentidos que esses modos produzem sobre as ações sociais. Segundo a autora, o desenvolvimento de uma prática social consciente é fundamental para que os cidadãos possam promover seus projetos, defender-se com um letramento consciente e maduro e fazer valer seus direitos.

\subsubsection{Estado-Nação}

O Estado-nação do século XIX assumiu que exercia o controle do mercado; a situação apresentada agora é que o mercado controla a maioria das instituições do estado. Em algumas instâncias, o estado age a serviço do mercado (...). Isso tem efeitos sobre as expectativas de comunicação. A preocupação do Estado era o desenvolvimento de cidadãos, de sujeitos sociais cuja identidade foi moldada por objetivos do Estado e pela preparação de uma força de trabalho para servir às necessidades de uma economia e da administração nacional. (...). Os interesses globalmente enquadrados das versões atuais do mercado não são nem sobre a cidadania, nem sobre a preparação de uma força de trabalho, seja para uma economia global, seja para uma economia nacional ${ }^{8}$ (GUNTHER KRESS, 2010, p. 19, tradução nossa.)

O Estado-Nação é uma unidade com fronteiras territoriais demarcadas que possui uma política que, pelos próprios meios, constitui um governo soberano. Enquanto um Estado é uma entidade política e geopolítica, uma Nação é uma unidade étnica e cultural. O termo "Estado-Nação" implica, por conseguinte, uma situação em que os dois são coincidentes. O Estado-Nação afirma-se por meio da capacidade de impor uma soberania sobre um povo em um dado território com fronteiras, com uma moeda própria e com forças armadas próprias. Ao longo da história, existiram Estados-Nação em diferentes épocas e lugares do mundo. Atualmente representam a forma dominante de organização geopolítica mundial.

\footnotetext{
${ }^{8}$ The nineteenth-century nation state assumed that it exercised control of 'the market'; the situation now is one where it seems clear that markets control the major institutions of the state. In some instances the state now acts as the servant of the market (...). This has had effects on expectations of communication. The (nation) state's concern had been the development of citizens - social subjects whose identity was shaped by the goals of the state - and the preparation of a labour force serving the needs of a national economy and administration. That state was interested in cohesion, integration and homogeneity - however imperfectly realized. The globally framed interests of current versions of the market are neither about citizenship - shared social values, aspirations, dispositions - nor about the preparation of a labour force, whether for a global economy.
} 
A ideia de pertencer a um grupo com uma cultura, com uma língua e com história própria tem um efeito psicológico na emergência do Estado-Nação, pois confere ao indivíduo segurança e certeza, enquadramento e referência civilizacional. Assim, o Estado-Nação é, na sua essência, conservador e tendencialmente totalitário, mas a sua independência tem pulverizado e retalhado grandes Estados antigos, gerando conflitos e escaladas de violência.

Os papéis e as relações de Estado-Nação e do mercado eram os principais fatores que moldavam a comunicação e, em certa medida, controlavam a economia nacional. Todavia, com as práticas de comunicação contemporâneas voltam-se à satisfação das exigências dos mercados globalmente organizados e, assim, o terreno das condições comunicacionais está sendo remodelado. Nesse novo processo, a linguagem age como vetor para a propagação de ideologias neoliberais e neoconservadoras de mercado, de Estado, de família e de indivíduos (CASTELLS, 2009).

Castells (2009, p. 39) expõe que, embora os Estados-Nação sejam sociedades estáveis de organização política, institucional e militar, nas condições da globalização, eles parecem dissolver-se em espaços de interação social. Como entidades soberanas legítimas, os Estados-Nação transformaram-se em formas de rede de Estado por meio de mecanismos que flexibilizam seus procedimentos de governança. Para se fortalecer, uns se associam e formam uma rede de Estado com múltiplos propósitos, outros enfocam um conjunto de assuntos constituindo-se como espaço de coordenação, de negociação e de debate com os outros Estados interessados. Os Estados mais fortes compartilham atributos de soberania estabelecendo redes permanentes para elaborar estratégias de administração da palavra. Isso tem efeitos sobre as expectativas de comunicação. A volatilidade das fronteiras e as constantes mudanças nas redes globais, que estruturam as práticas sociopolíticas, provocam mudanças nos gêneros construídos nas intersecções das redes multidimensionais.

Em condições capitalistas avançadas, o mercado capitalista promove ativamente a fragmentação social. Para maximizar as potencialidades de nichos de mercado, os meios de comunicação apoiam o desenvolvimento de estilos de vida distintos. Contudo, nesse contexto, as considerações em torno de práticas 
profissionais e as questões éticas são cada vez mais deixadas a esforços individuais e a formas de comunicação e de regulação não patrocinadas pelo Estado.

Kress (2010, p. 19-20) assegura que a comunicação continuará a ser sujeita aos contextos socioculturais, econômicos e políticos e que os meios para ressignificar e comunicar formas simbólicas são definidos por determinações de assuntos (pautas) que sejam relevantes para a sociedade. As tecnologias de representação e de divulgação de situações e eventos e os recursos e facilidades que elas oferecem são utilizadas dentro do quadro do que é socialmente possível, de modo que as práticas, os recursos e as tecnologias de comunicação respondem em diferentes taxas e em diferentes momentos da evolução social, econômica e tecnológica.

\subsubsection{Mídia, mediação e a quase interação mediada}

Em seu estudo sobre a mídia, Silverstone (2002, p. 17) afirma ser ela um processo social que contribui para a capacidade humana de compreender o mundo, de produzir e de partilhar significados cotidianamente. Entender a mídia como um processo social implica o reconhecimento de que ela é fundamentalmente política ou talvez, mais estritamente, politicamente econômica. A política da mídia envolve a focalização de visões que desafiam os valores éticos morais e a legitimidade da própria democracia.

De acordo com o autor, os significados produzidos pelas comunicações que inundam as sociedades contemporâneas saíram de instituições, cada vez mais globais em suas sensibilidades e suas insensibilidades. São eles que constroem a realidade, filtram e moldam as realidades cotidianas instituindo o que é real ou não, por meio de semioses singulares e múltiplas, fornecendo critérios e referências para a condução da vida diária e para a manutenção de um senso comum. Como diz Silverstone (2001, p. 3):

Nossas histórias, nossas conversas estão presentes tanto nas narrativas da mídia (...) como em nossos contos do dia a dia: a fofoca, os boatos, e interações casuais em que encontramos maneiras de nos fixar (...) no espaço e no tempo e em nossas interrelações, conectando e separando, compartilhando e negando, individual e coletivamente, na amizade e na inimizade, na paz e na guerra. 
A nossa experiência social é cada vez mais mediada pelas formas e pelos conteúdos dos gêneros e dos discursos cotidianos. medeia Os significados mediados pela mídia de um texto para outro, de um discurso para outro, de um evento para outro, estendem-se para além do contato com os seus espectadores e leitores. O processo de mediação das semioses contemporâneas tem possibilitado o entrelaçamento do público e do privado para que a experiência social seja moldada. As formas midiáticas resultantes do desenvolvimento das novas tecnologias de comunicação não esperam que os indivíduos situados em variados contextos participem desse entrelaçamento, mas elas fornecem as palavras a serem ditas, as ideias a serem expressas como parte da realidade, permitindo aos indivíduos que as consomem pouca ou nenhuma escolha.

Ao referir-se ao aumento notável da comunicação mediada por meio das tecnologias de comunicação e de informação controladas e não controladas, Fairclough (2006, p. 77) afirma estarem elas ligadas, principalmente, às práticas econômicas políticas da mídia contemporânea. Em relação ao discurso, as novas formas comunicativas diferenciam-se em termos de via de mão dupla e de via de mão única, e em relação à comunicação, elas distinguem-se em termos de comunicação não mediada e mediada.

A via de mão dupla não mediada diz respeito à comunicação face a face e a via de mão dupla mediada ao telefone e às redes. Por sua vez, a via de mão única não mediada envolve a leitura e a via de mão única mediada é a utilizada pelos meios de comunicação impresso, rádio, televisão e internet. Com o desenvolvimento das novas tecnologias de comunicação e de mediação, as formas simbólicas de comunicação passaram a ter novos formatos. A combinação de diferentes modos semióticos serve para ativar, complementar e reforçar significados/sentidos ou para contradizê-los (FAIRCLOUGH, 2003).

Quanto aos meios tecnológicos de comunicação, Thompson (2011, p. 120) chama a atenção para as novas formas de (inter)ação, por meio das quais os relacionamentos sociais são criados: a interação face a face, a interação mediada e a quase interação mediada. No contexto de interação face a face, os participantes presentes dialogam dispondo de uma multiplicidade de deixas simbólicas visuais que reduzem a ambiguidade e clarificam a compreensão das mensagens 
transmitidas e recebidas. Em contraste com a interação face a face, as interações mediadas utilizam meios técnicos que possibilitam a transmissão de mensagens entre participantes situados em contextos espaciais e/ou temporais distintos. Para que as mensagens transmitidas sejam interpretadas por seus participantes, estes devem estar atentos às deixas orais incluídas no intercâmbio das informações.

A quase interação mediada pelos meios de comunicação de massa jornais, revistas, rádio, televisão - é vista como um tipo de interação de sentido único diferente das outras formas de mediação pelo fato de ela ser disseminada a um número indefinido de receptores potenciais. Para Fairclough (2003), esse tipo de mediação é uma via de mão única, produzida com limitada possibilidade de deixas simbólicas visuais e sem o grau de reciprocidade interpessoal das outras formas de interação. A interação mediada e a quase interação mediada eram restritas a setores pequenos da população no passado. Atualmente, os indivíduos preferem buscar informações e conteúdos simbólicos em fontes on-lines em vez de nas pessoas com as quais interagem no dia a dia.

Thompson (2012) analisa que interações podem envolver uma mistura de diferentes formas: indivíduos que discutem face a face em uma sala podem atender a um telefonema, ouvir uma notícia e voltar a conversar. Também um programa de televisão pode mostrar a interação face a face entre membros de um debate ou de uma mesa redonda, mas continuará sendo uma quase interação mediada. É importante destacar que, na quase interação mediada, não há monitoração reflexiva das respostas entre interlocutores. Se, por um lado, ela assegura o alargamento das informações produzidas com liberdade e criatividade, por outro, ela mantém a incerteza, a inércia e a preocupação, por privar os produtores das mensagens midiáticas do feedback dos receptores que Ihes permitiria verificar o grau de entendimento, de aceitação ou de rejeição a elas.

No contexto do novo capitalismo, as semioses globais quase mediadas são as mais apropriadas para a construção de ideologias a serviço do poder e da dominação (THOMPSON, 2011). Em narrativas sobre acontecimentos impactantes, os participantes, em vez de interativos, são representados e relacionados a processos de ação unilaterais, em cujas estruturas visuais os participantes representados não têm objetivos ou metas (KRESS e VAN LEEUWEN, 1996, 2006). 
Embora os receptores desse tipo de mediação possam controlar, de certa forma, a natureza e a extensão de sua participação e até mesmo utilizá-la para finalidades próprias, podem intervir muito pouco devido a sua própria posição de receptor de bens informativos de consumo. Ora, não havendo a responsabilidade de receptores intervirem nesse tipo de mediação, maior liberdade é conferida à produção e à mobilização de mensagens globalistas ideológicas.

Thompson (2012) chama a atenção para um tipo de mediação que envolve outros contextos nos quais as mensagens são recebidas e respondidas a outros espacial e temporalmente distantes: a mediação estendida. Um indivíduo que não tenha ouvido o noticiário televisivo sobre um incidente, por exemplo, terá oportunidade de tomar conhecimento dos fatos por meio dela, de rever a compreensão do incidente para que, apropriando-se da mensagem, possa incorporá-la à própria vida ou intervir sobre ela.

Contudo, a reação a uma narrativa jornalística, por parte de indivíduos situados em diferentes contextos, requer que as imagens e as expressões responsivas possuam certo grau de organização e de coordenação dos contextos de recepção, além do apoio das fontes midiáticas para serem mediadas na mesma extensão e com a mesma rapidez das informações da mídia. Isso significa que a reação responsiva dos receptores das narrativas midiáticas é bastante restrita e que a elaboração e difusão de mensagens ideológicas quase mediadas pela mídia de massa realiza-se com bastante liberdade (THOMPSON, 2012, P. 147).

Fairclough (1995, p. 44-45) explica que, nas representações da mídia, os textos podem funcionar ideologicamente na medida em que eles contribuem para a reprodução das relações sociais de dominação e exploração. De acordo com o autor, as representações ideológicas nos textos são geralmente mais implícitas do que explícitas e incorporadas em formas de uso naturalizado da língua como senso comum para as audiências.

No Brasil, pesquisa de mídia solicitada pela Secretaria de Comunicação Social da Presidência da República (2013) revela que a televisão, o meio de comunicação de maior audiência, tem a preferência daqueles que a assistem (80\% da população brasileira) devido, principalmente, às narrativas jornalísticas. O rádio, meio de comunicação que ocupa o segundo lugar no raking, garante sua maior 
audiência na região Sul do país. Embora 53\% da população não acesse a internet, ela está em terceiro lugar, por ser o meio de comunicação mais cotado pelos jovens - as redes sociais, com a prevalência do Facebook, aparecem como as mais acessadas, seguido por portais essencialmente ligados à mídia impressa. Isso significa que a produção convergente de narrativas impressas e on-lines se fortalece em uma simbiose com os outros meios de comunicação, em virtude da preferência nacional.

A liberdade para que os meios de comunicação selecionem e retratem os acontecimentos da vida cotidiana permite que a mídia influencie o curso dos acontecimentos e até aspectos da vida privada. Eventos públicos como os debates restritos apenas àqueles que deles participaram e aos quais poucos tinham acesso tornaram-se de consumo privado universal, e os eventos privados como eventos da vida privada - íntima e particular - de pessoas públicas e famosas, tornaram-se públicos. Exemplos concretos disso são as representações narrativas difundidas nas capas das revistas francesa Closer (Figura 16 - Seminudez da Princesa Kate) e da revista Veja (Figura 17 - Doença de Angelina Jolie).

Figura 16 - Seminudez da Princesa Closer, 14 de setembro de 2012

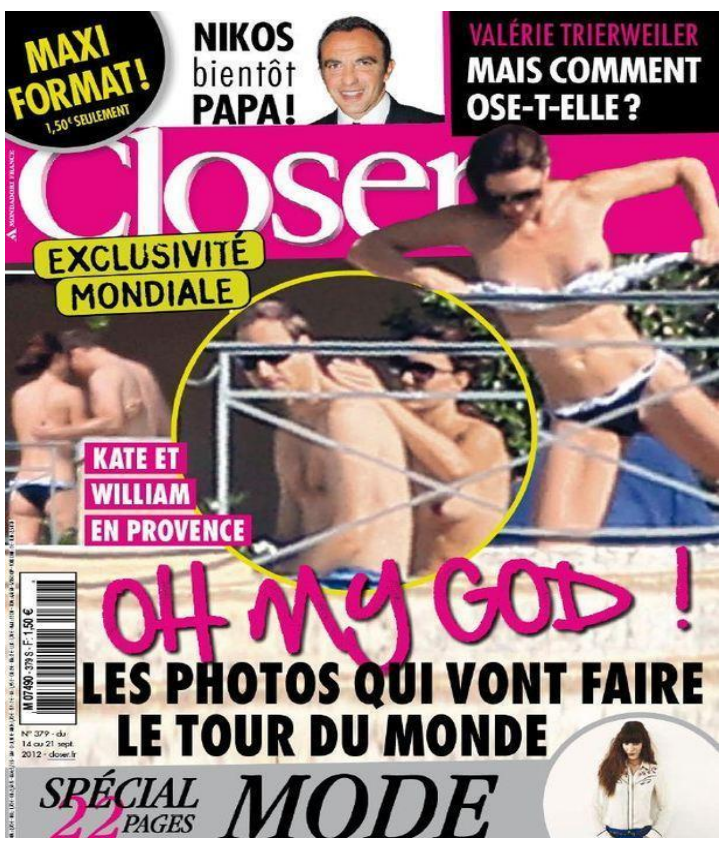

Fonte: Capa da revista Closer.
Figura 17 - Angelina Jolie Veja, 22 de maio de 2013

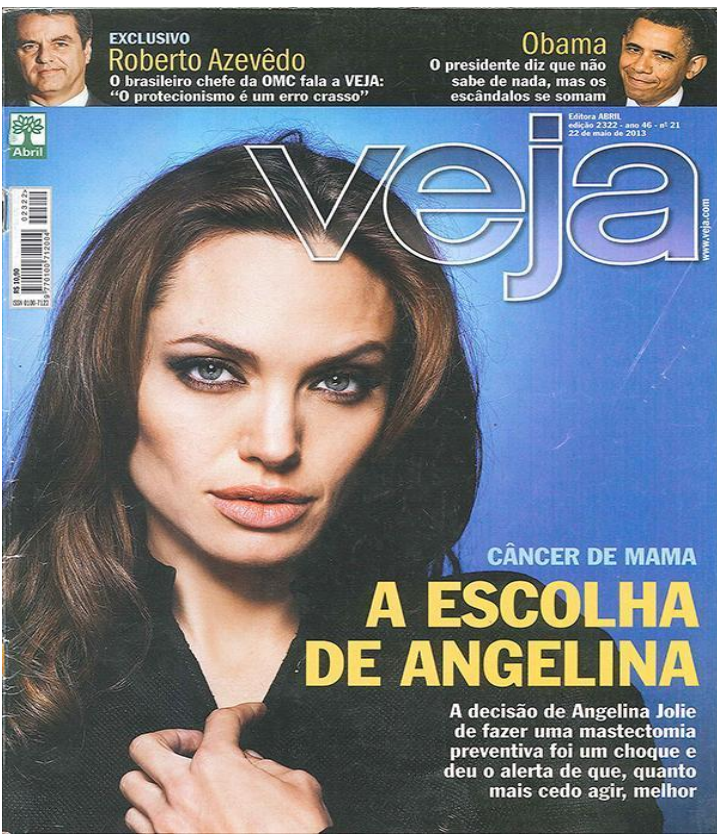

Fonte: Abril, edição 2.322, ano 46, n. 21. 
Os textos multimodais chamam a atenção porque os participantes representados na estrutura não são pessoas comuns, mas membros da família real inglesa. A imagem da princesa Kate seminua em posição frontal, no primeiro plano da imagem, à direita do texto (Figura 16), causa impacto em virtude da veracidade da foto. A imagem da atriz Angelina Jolie, por sua vez, (Figura 17) traz, devido à informação CÂNCER DE MAMA, ao conhecimento do público a doença da famosa atriz americana famosa.

É importante enfatizar que a observação deve ir vai ao encontro não de censurar as formas mediadas pelos meios de comunicação, tão pouco de legislar sobre a verdadeira representação da realidade, mas dos significados que se justificam no argumento da supremacia da liberdade de levar ao público os fatos do mundo real.

\subsubsection{Poder da comunicação}

A expressão poder da comunicação refere-se ao potencial das formas simbólicas veiculadas pelos meios de comunicação de massa para que, tendo efeito de sentido sobre a opinião pública, atinjam determinados objetivos ou fins. Segundo Castells (2009), as narrativas difundidas pelos meios de comunicação tecnológicos são, mais do que nunca, um componente essencial e volátil nas lutas de poder em que a opinião pública seja um fator importante. Para alcançar a confiança do público nas novas mídias, é mantida uma política rotineiramente baseada na suposição de que uma apresentação de qualidade é absolutamente vital em todas as circunstâncias normais. As condições ao exercício eficaz de poder das novas mídias envolvem ações de setores especializados capazes de atingir, por meio da divulgação de mensagens narrativas, alto nível de consenso e de credibilidade.

Mcquail (2013) esclarece que comunicação de massa controlada por relações de poder arraigadas nos negócios da mídia e na política de estado é gerenciada por processos de comunicação que a distinguem de outras formas de comunicação social. Suas propriedades especiais são, em parte, atribuíveis às diferenças entre os meios de comunicação e às tecnologias que eles recorrem. A imprensa baseada na escrita usa as tecnologias de (re)produção fotográfica, de design gráfico e de impressão como canal visual. O rádio usa a fala e as tecnologias 
de som, de gravação e de transmissão. A televisão combina as tecnologias de som, de gravação, de imagens e de radiodifusão e relaciona os modos de comunicação orais, sonoros, visuais e escritos. Essas diferenças têm implicações significativas amplas em termos do significado potencial da mídia. A impressão é, em um sentido importante, menos pessoal do que o rádio ou a televisão. $O$ rádio permite que a individualidade e a personalidade da pessoa sejam transmitidas pela voz. A televisão leva o processo mais longe ao fazer com que as pessoas visualmente disponíveis sejam vistas em movimento e ação. Sua tecnologia se harmoniza com a orientação da nossa cultura contemporânea: foco individualismo e na personalidade. A televisão, como tecnologia, também favorece ação, em vez de contemplação e coloca em primeiro plano o presente. Mesmo nos programas pré-gravados, a ilusão de vivacidade e de imediação é mantida. O corte rápido entre as imagens gera ação e emoção, enquanto o close-up de pessoas reduz a distância social e transmite um ethos igualitário.

Com Macluhan (1964, 2012), foi possível perceber que os processos comunicativos e as práticas sociais determinadas pelos meios de comunicação são extensões do sistema nervoso humano, capazes de criar um entorpecimento, aos olhos humanos, de tal forma que novos ambientes - imagens, sons, emoções - não são percebidos devido aos efeitos dos meios de comunicação. Mesmo que cresça nos receptores das mensagens midiáticas a falsa sensação de que desfrutam incondicionalmente dos benefícios resultantes da "liberdade de expressão", tornouse comum ceder aos novos efeitos sensoriais, fechar os e deixar-se moldar por eles.

Pesquisa científica recentemente desenvolvida por Manuel Castells (2009) sobre a comunicação de redes e os processos da mente humana revela que o poder da comunicação está no coração da estrutura e na dinâmica da sociedade. As estruturas determinantes do poder são construídas e gerenciadas por relações de poder e de dominação em todos os domínios da prática social, incluindo a prática política e os negócios da mídia. Isso significa que é por meio da ativação de redes de associação entre eventos sociais e de imagens mentais, via processos de comunicação, que a produção do poder opera, estruturando o modo como pensamos, sentimos e agimos. De acordo com Castells (2009) a linguagem e a mente se comunicam principalmente por meio das metáforas que constroem as narrativas. De acordo com o cientista, as metáforas que constituem as estruturas 
narrativas não acessam as redes neurais do cérebro humano. O que acessa essas redes são as narrativas construídas por metáforas. São as narrativas que atualizam formas de comunicação políticas, que evocam emoções, sentimentos e componentes do raciocínio aptos a despertar experiências e a provocar tomadas de decisão. Nesse sentido, Fairclough (2012, p.3) assegura que as narrativas funcionam como parte das ações econômicas e políticas, principalmente, quando representam as pessoas como personagens e quando os argumentos mobilizados nelas desencadeiam processos de tomadas de decisão. Também Kress e van Leeuwen (2006) afirmam que a persuasão realizada por representações narrativas compostas por metáforas (frames) definem papéis e valores relacionados às práticas sociais dentro de contextos específicos. A propósito, destacamos um exemplo de como a empatia social e o envolvimento com os participantes representados na narrativa (Figura 18) publicada na capa da revista americana Newsweek foi construída:

Figura 18 - Heróis americanos

Revista Newsweek, 12 de novembro de 2012

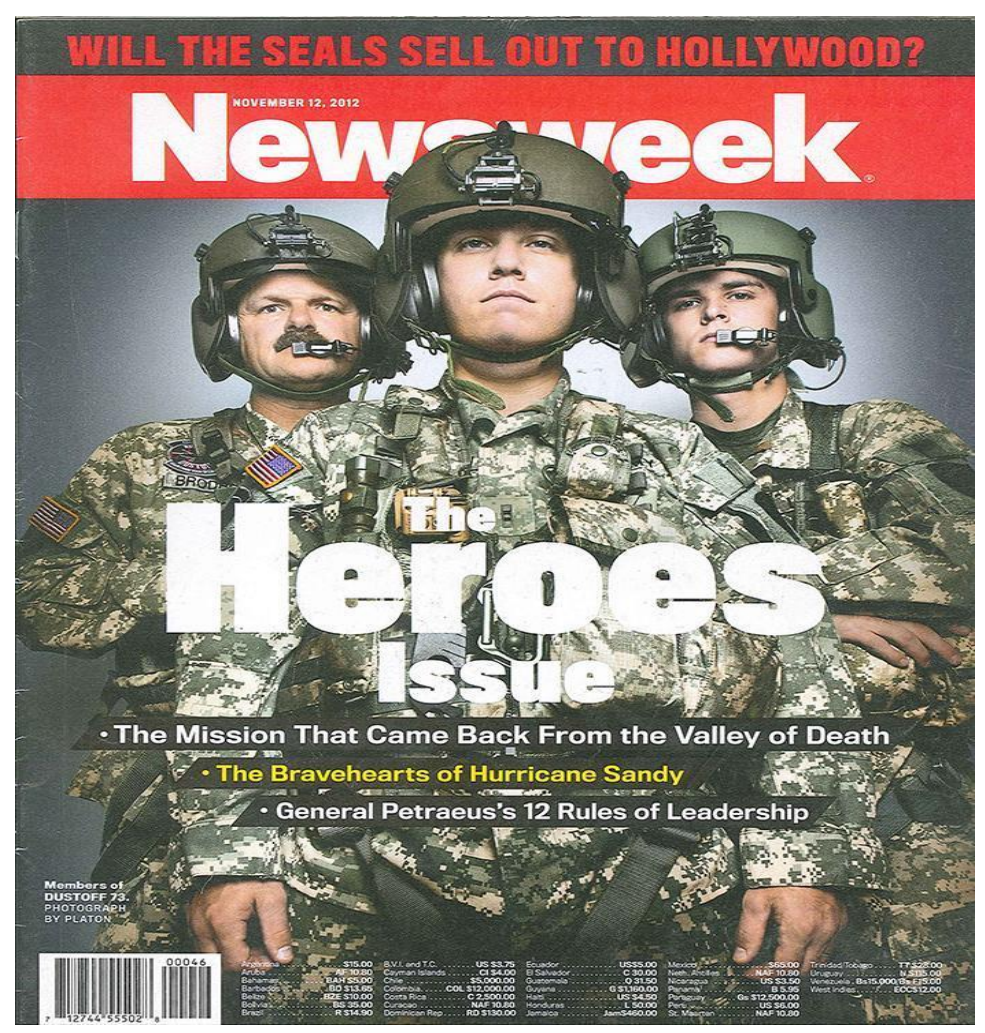

Fonte: Revista Newsweek, capa. 
Os modos semióticos (discursivo e visual) que compõem essa estrutura multimodal acima se integram no todo composicional - a escrita centralizada juntamente com os participantes representados por um processo não transacional os transforma em um evento social. Nessa representação narrativa (VAN LEEUWEN, 2005) os participantes meta - identificados pelo uniforme militar e por intermédio de palavra grafada em fonte 'robusta' de tamanho grande, são representados visualmente como heróis por meio do ângulo elevado e frontal denotativo de envolvimento e energia. Este é um exemplo que interliga o público leitor a uma identidade militar coletiva. O propósito do texto multimodal possivelmente busca alcançar um resultado: legitimar ações militares americanas.

\subsection{Narrativas da mídia contemporânea}

Muitas situações e eventos experimentados e relatados por indivíduos, grupos e instituições sociais poderiam servir de fonte de comunicação para os suportes de difusão da informação, definidos como espaços discursivos de transmissão de mensagens - a imprensa, o rádio, a televisão, a internet -, por meio dos quais as narrativas circulam como o capital mais volátil e precioso à credibilidade do jornalismo (MACQUAIL 2013, p. 247), mas não são processados, em virtude da primazia dada aos contextos sociais, aos assuntos econômicos e políticos de agenda da mídia, e às formas de interesses sociais.

Narrativas midiáticas conformadas por modelos de contextos globais e locais são produzidas de certos modos por diferentes suportes físicos de difusão da informação. Isso significa que a estruturação de uma narrativa, como parte de um evento sociocomunicativo, é direcionada por modelos de contextos, por convenções do gênero e por interesse do público em geral. O processo pode ser configurado no seguinte quadro: 


\section{Quadro 1 - Pré-estruturação de uma narrativa midiática}

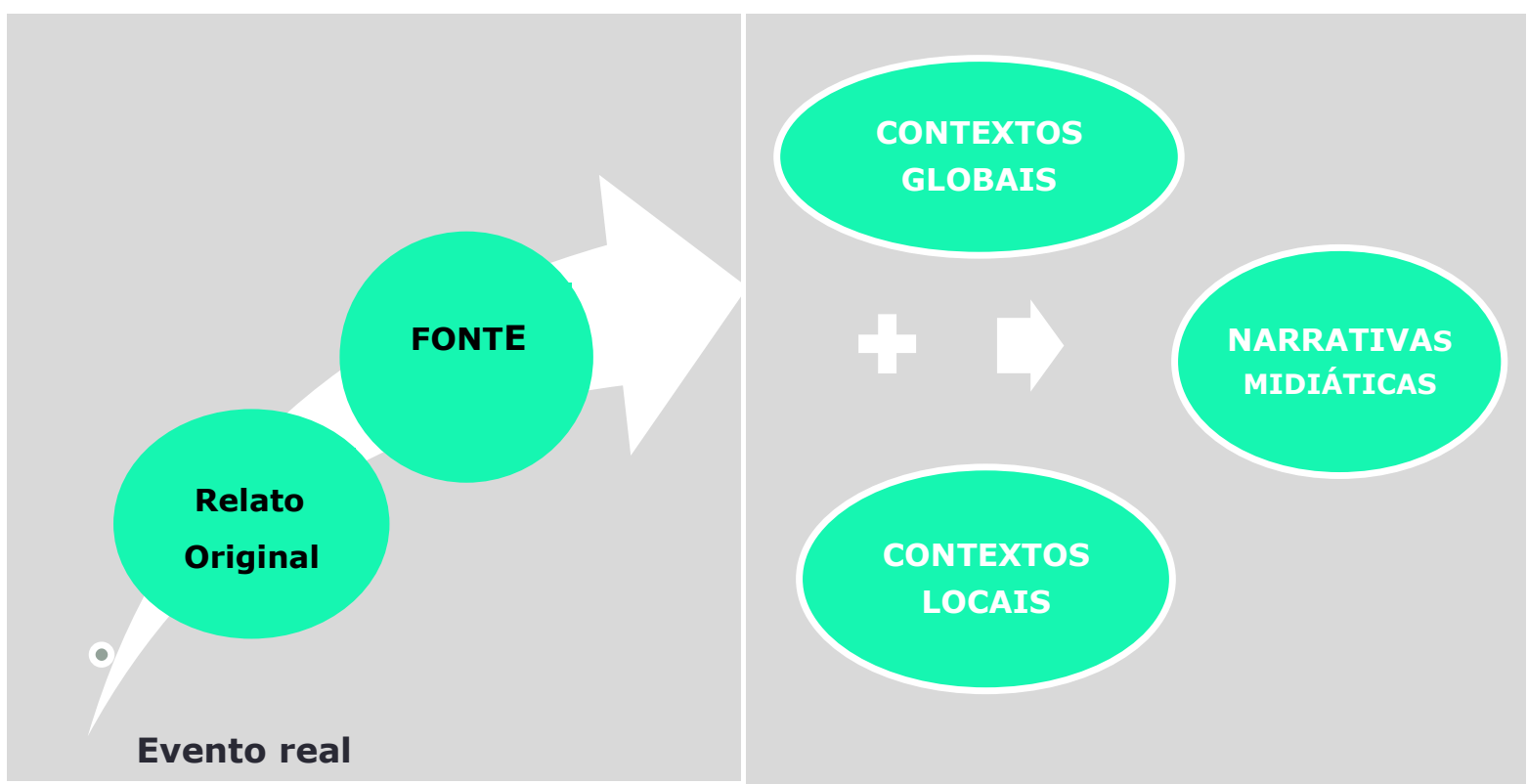

Fonte: Elaborado pela autora com base em Fairclough (2003) e em van Dijk (2011).

As narrativas midiáticas multimodais são formas de ação e de interação que articulam as informações que a cultura considera ser de valor comum. Por meio delas o ser humano em sua complexidade é constituído, compreendido e o mundo social é demarcado. São elas que servem de meio para o conhecimento dos fatos e dos acontecimentos, mas como artefatos simbólicos, elas não são reproduções fiéis da realidade. A história dos meios de comunicação mostra a importância precoce e perene de um serviço de produção de narrativas atualizadas, mas que depois foram transformadas em mercadoria para o comércio internacional, de modo que tornaramse um gênero mais ou menos padronizado e universal (MACQUAIL, 2013, p. 147).

Motta (2013, p. 95-103) distingue as narrativas de reportagens (softnews) das narrativas editoriais (hardnews) e das narrativas históricas. As reportagens, por exemplo, permitem que o produtor do gênero tenha liberdade de narrar fatos e acontecimentos (dramas, tragédias, fatos insólitos, lugares pitorescos etc.) em estruturas que produzem menos efeitos de veracidade e mais efeitos estéticos. As narrativas de editoriais (sobre política, economia, cidades e eventos internacionais), elaboradas em terceira pessoa, em linguagem objetiva e direta de modo a manter a proximidade com o referente empírico, produzem efeitos de veracidade. Fragmentadas e inconclusas, essas narrativas (hardnews) não encadeiam 
sequências integrais, nem compõe uma intriga no sentido integral do termo. Assim, para que seus fragmentos dispersos sejam compreendidos, é preciso reordená-los em uma unidade temática coerente, como atividade de representação realista dos eventos narrados e como atividade constituidora do pensamento contemporâneo. As narrativas históricas, por sua vez, fazem com que os acontecimentos do presente tomem a forma de sequências e com que as novidades adquiram significação minimamente coerentes e ainda relativamente provisórias.

Embora as diferenças entre as narrativas midiáticas e as imaginadas possam não estar muito clarificadas teoricamente, algumas diferenças entre ambas podem ser exemplificadas. Uma narrativa midiática, por exemplo, começa assim: "Quinze pessoas ficaram feridas hoje, quando um ônibus caiu...". Já a narrativa imaginada (uma fábula, por exemplo) inicia assim: "Era uma vez (...)". Nas narrativas de impressos, a sequência é geralmente organizada no formato padronizado da escrita e a ordem de sentido é estabelecida por meio da inserção e da atualização de conhecimentos e de ligações (coerentes, complementares ou contrastantes).

Elementos, tais como: quem, o quê, por quê, onde e quando, são geralmente localizados na parte superior da história. A complicação (evento narrado), a definição (plano de fundo) e o resultado da história são os elementos que estruturam o enredo. Em virtude do foco no desdobramento dos eventos relatados geralmente, não há uma resolução final. Uma situação oposta à outra gera efeitos de sentido que podem ser significativos. Esse formato padrão, porém, não é o único modo de estruturação das narrativas jornalísticas.

Eventos sociais também podem ser representados com uma introdução incompreensiva em que tudo é comunicado no segundo parágrafo. Assim, ela invariavelmente começa com um pronome (ele ou ela, eles ou elas), precisamente, com uma referência catafórica em que o pronome se refere ao seu correferente. A intenção é criar um senso de antecipação para que o leitor busque saber a quem ou a que o pronome se refere. Em contraste com a forma típica já mencionada, a primeira menção forneceria o nome de um indivíduo ou as informações necessárias revelando a que o texto se refere (RICHARDSON, 2007). 
Fairclough (2003) distingue história de fábula e de texto narrativo, mas sem induzir ao sentido de independência de um aspecto da narrativa em relação ao outro. $\mathrm{Na}$ análise da narrativa jornalística proposta por Fairclough o texto narrativo é desassociado da história porque as histórias narradas não são idênticas às histórias relatadas e também porque o procedimento é útil ao estabelecimento da estrutura textual do conteúdo realizado.

O autor explica que em uma narrativa midiática a sequencia lógica e cronológica dos eventos apresenta-se como uma ordem diferente da original, na qual os agentes são transformados em personagens, para a focalização de um ponto de vista particular.

O conteúdo de um texto narrativo é produzido com a coloração de uma fábula e pode ser apresentado por um instrumento midiático particular (narrativa impressa, televisiva, on-line, etc.). Com efeito, o texto transmitido por um agente, por meio de imagens ou da combinação dos modos semióticos, para o público é lido pelos receptores da história narrada, mas o que permanece como um traço de memória, após a leitura do texto, é a fábula influenciada pelo narrador do texto, pela leitura do próprio leitor e pelas manipulações da história.

Os dois textos adiante (Figura 19) foram veiculados na primeira página do jornal Correio Braziliense de 25 de maio de 2012. Ambos mostram como gêneros distintos - a narrativa ficcional e a narrativa jornalística-, podem ser semanticamente entrelaçados na página jornalística de modo a ter efeito ideológico de sentido.

As narrativas midiáticas apresentam-se separadas pelo frame da manchete “... ERA UMA VEZ UMA CPI”. A primeira é uma reportagem (softnew) acerca de um musical baseado na fábula universal da Branca de Neve. A segunda, uma narrativa de editorial (hardnew) que retrata um evento político crítico. Iniciada com a expressão típica da narrativa ficcional “... ERA UMA VEZ (...)”, a manchete é complementada pela expressão “(...) UMA CPI” que a hibridiza, ironizando o evento político. 
Figura 19 - Narrativas jornalísticas

\section{Correio Braziliense, 25 de maio de 2012}

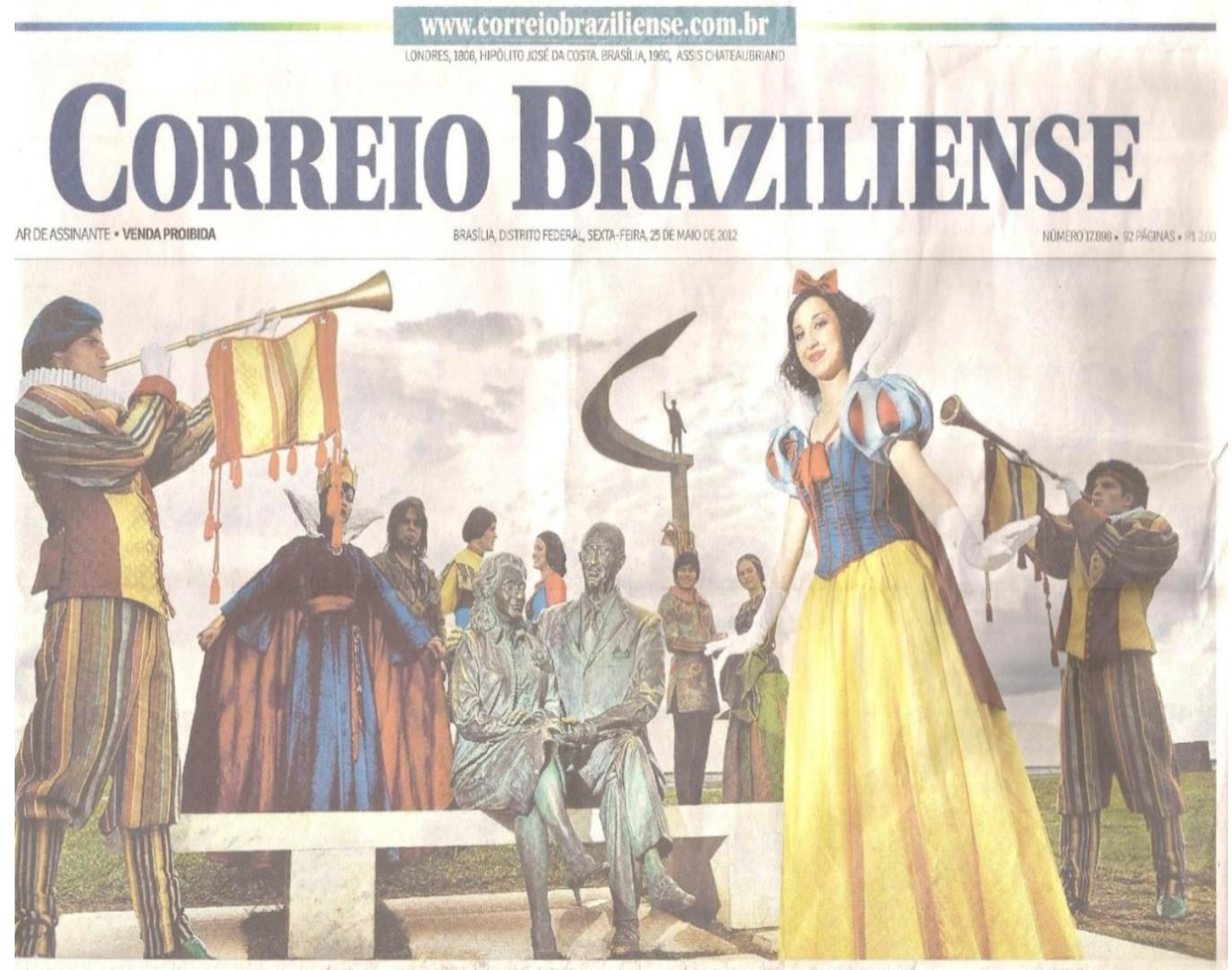

E num reino não Principais artistas do musical Branca de Neve, que será encenado amanhãe domingo no Centro de Convençōes, posam para fotós no Memorial JK, üm dos cartōes-postais maisfamosos de Brasflia Boas opcóes para se divertir não faltam. Háo Festival de Opera, que comeca hoje com La Bohème, no Teatro Nacional; o show gnatuito do elogia multo distante... do Criolo, domingo, no CCBB; além de um roteiro como que rola de melhor nos cinemas, teatros e bares da capital. PÁGINA 32 ECADERNOS DIMRTA-SEE DIVERSÅ 8 ARTIE

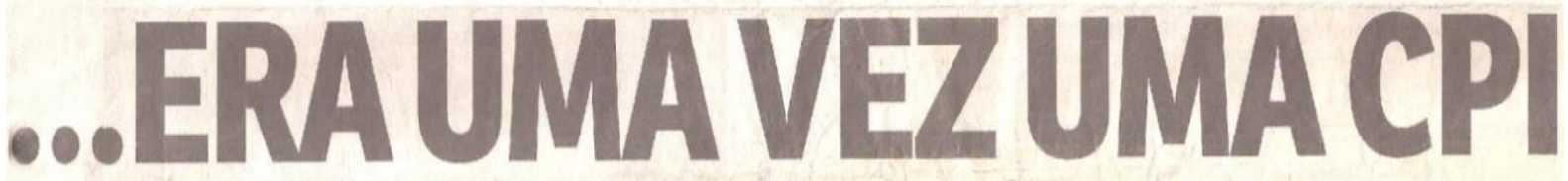

A exp ressão do presidente da CPI do Cachoeira, Vital do Rêgo Filho (foto), éum retrato do fiasco que se anuncia.Tudo conspira para que os trabalhos da comissão acabem em pizza. Exemplo disso foi a reunião em que senadores e deputados do PSDB, às 7h30, no entẫo deserto cafezinho do Senado, decidiram: para evitar a convocação do governador tucano Marconi Perillo, eles deixam de brigar para que Agnelo Queiroz (PT), do DF, e Sérgio Cabral, do Rio, também sejam obrigados a deporna CPI. Ontem, dados do contador de Cachoeira mostraram que o escritório de Geraldo Brindeiro, subprocurador-geral da República, recebeu $\mathrm{R} \$ 161$ mil de empresas ligadas ao esquema do bicheiro, PAGMaS2A4

Fonte: Correio Braziliense, exemplar n. 17.898, 92 p., p. 1. 
A reportagem (softnew) focaliza uma cena representativa do evento cultural com um viés político: a Branca de Neve no primeiro plano da estrutura e o memorial do Presidente Juscelino no fundo do design. Já a narrativa editorial (hardnew) tem como participante visualmente representado o Presidente de uma Comissão Parlamentar de Inquérito que investigava a relação de um bicheiro com parlamentares e com agentes públicos e privados, mas que foi cancelada por razões políticas.

Embora uma Comissão Parlamentar de Inquérito seja normalmente vista como um benefício ao país, o exercício do poder a banaliza. Isso se justifica por meio da observação de vários aspectos: a expressão do produtor da manchete (Era uma vez uma $\mathrm{CPI}$ ); o comentário do jornalista no desfecho da matéria (A CPI é um fiasco) e a foto que expressa a frustração do presidente da Comissão Parlamentar de Inquérito diante do cancelamento dos trabalhos iniciados. Mas a reportagem, devido à proeminência da sua mensagem, ao tamanho da sua imagem e à sua modalização (coloração de fábula) sobrepõe-se à narrativa editorial. Isso mostra que as narrativas não são neutras. Elas envolvem julgamentos de interesse particular, manipulam mensagens e abrem questões de verdade.

Van Dijk (2011, p. 144) ressalta que as narrativas midiáticas precisam ser analisadas juntamente com suas práticas sociodiscursivas, e que isso envolve a investigação dos modelos de contexto que as controlam. Segundo o autor é importante investigar as narrativas imagéticas - com fotos e imagens ocupando mais da metade do espaço das primeiras páginas e das capas de revistas -, principalmente aquelas que não identificam os nomes dos seus produtores e nem os modos de definição dos atores sociais que servem para a confirmação de estereótipos.

Para van Dijk, é importante a análise da macroestrutura do texto - podendo esta ser deduzida com base em processos de conhecimentos de mundo e nos interesses pessoais - para o desvelamento dos significados ideológicos incorporados nela. Salientamos que, segundo van Dijk (2008) uma narrativa jornalística constitui-se de sumário, de background, de um evento principal, de eventos prévios, de consequências e de comentários. O sumário, formado pela manchete (lead) informa os receptores do texto sobre o fato noticioso; o background 
refere-se às partes do texto que fornecem o contexto do evento e as informações sobre outros eventos. O evento principal é o que constitui a narrativa propriamente dita e os eventos prévios podem ou não estar explícitos. As consequências são a parte do texto que organiza os eventos descritos como decorrentes do evento principal. No comentário, aparecem as conclusões e outras informações sobre o evento principal.

Extraímos, da página do jornal Correio Braziliense (Figura 19), a narrativa (hardnew) e a transcrevemos abaixo para analisar a sua macro-estrutura, segundo a orientação dada por van Dijk ( 2008) e os significados ideológicos do texto.
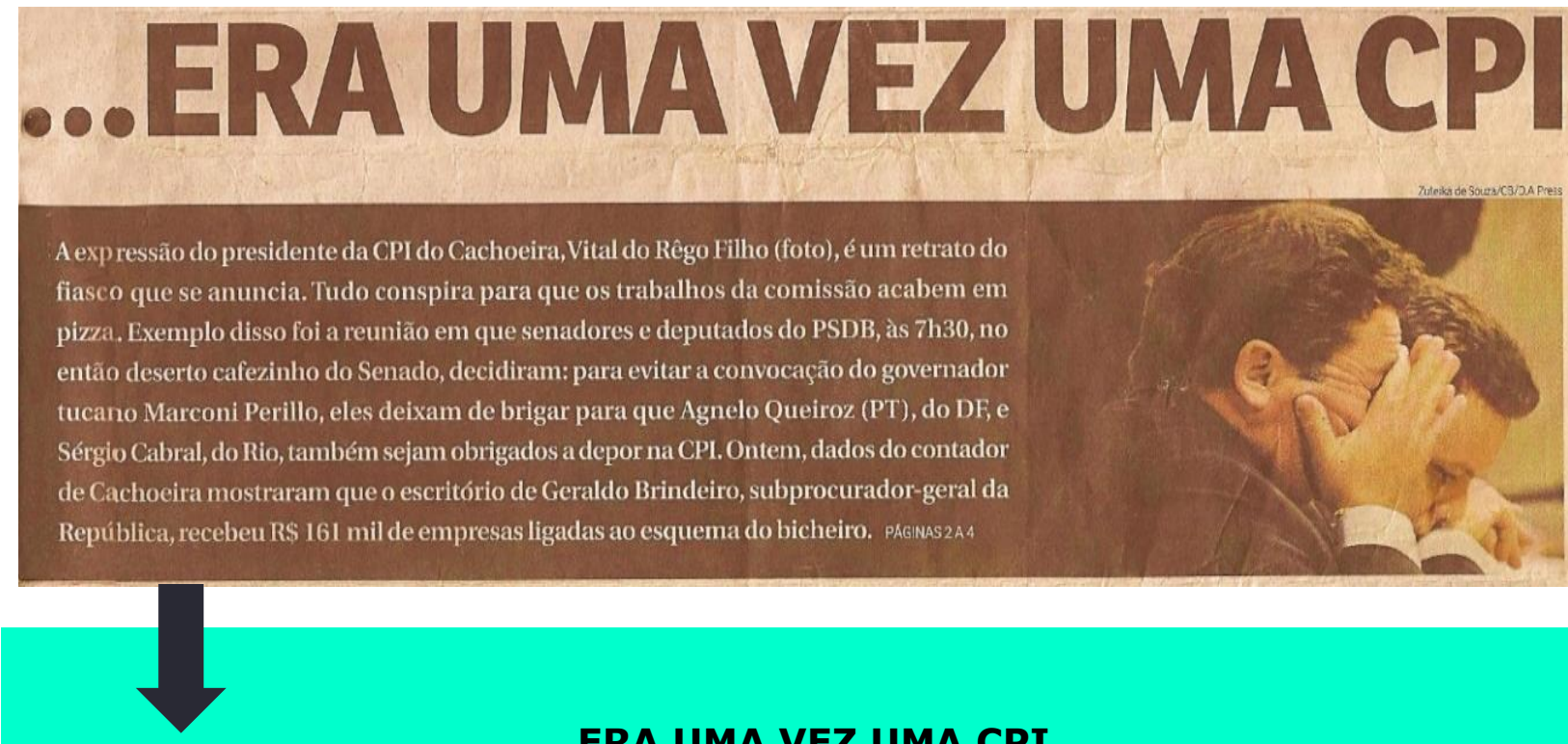

\section{...ERA UMA VEZ UMA CPI}

A expressão do presidente da CPI do Cachoeira, Vital do Rêgo Filho (foto), é um retrato do fiasco que se anuncia. Tudo conspira para que os trabalhos da comissão acabem em pizza. Exemplo disso, foi a reunião em que senadores e deputados do PSDB, às 7h30, no então deserto cafezinho do Senado, decidiram, para evitar a convocação do governador tucano Marconi Perillo: eles deixam de brigar para que Agnelo Queiroz (PT), do DF, e Sérgio Cabral, do Rio, também sejam obrigados a depor na CPI. Ontem, dados do contador de Cachoeira mostraram que o escritório de Geraldo Brindeiro, Subprocurador-geral da República, recebeu R\$161 mil de empresas ligadas ao esquema do bicheiro. 
MACROESTRUTURA DA NARRATIVA

MANCHETE

...Era uma vez uma CPI (Comissão Parlamentar de Inquérito).

CONTEXTO SOCIAL

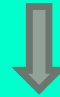

O contexto do evento não está claramente explícito, mas as sequências de nível menor como: (...) "Presidente da CPI do Cachoeira $(. . .)^{\prime \prime}$ e "(...) os trabalhos da CPI $(\ldots)$ ", o sugerem.

NARRATIVA DO EVENTO PRINCIPAL

O fracasso da Comissão Parlamentar de Inquérito instaurada para investigar relações de parlamentares com um bicheiro, preso por cometer crimes de corrupção ativa e passiva e de lavagem de dinheiro.

OUTROS EVENTOS

Reunião de Senadores e Deputados do PSDB com finalidade explícita, mas pressuposta;

Referência ao recebimento do valor de $\mathrm{R} \$ 161 \mathrm{mil}$ de mil, de empresas ligadas ao esquema do bicheiro, mas sem o agente da ação de receber.

CONSEQUÊNCIAS DO EVENTO PRINCIPAL

Não há consequências explícitas.

COMENTÁRIO

A CPI é um fiasco 
Embora o contexto não esteja explicitado, sabemos que a Comissão Parlamentar de Inquérito foi instaurada oficialmente no Congresso Nacional para investigar a relação de Carlos Augusto Ramos com parlamentares, com agentes públicos e privados. Preso em uma operação que desarticulou uma quadrilha de jogos ilegais em Goiás, Ramos foi acusado de corrupção ativa e passiva, de falsidade ideológica, de contrabando, de exploração de jogos de azar e de lavagem de dinheiro. Grampos e relatórios da Polícia Federal (PF) amplamente divulgados pela imprensa apontaram a relação do bicheiro com parlamentares do Partido dos Trabalhadores (PT), do Partido Socialista Democrático Brasileiro (PSDB), do Partido Popular (PP), do Partido Trabalhista Brasileiro (PTB), do Partido Popular Socialista (PPS) e do Partido Comunista do Brasil (PCdoB) entre eles, o senador Demóstenes Torres (ex-DEM-GO), com os governadores Marconi Perillo (PSDB-GO) e Agnelo Queiroz (PT-DF) e com a empresa Delta, empreiteira com maior número de obras no Programa de Aceleração criado pelo Governo Federal. A comissão formada por 16 senadores e 16 deputados, além dos suplentes, teve o prazo de 180 dias para concluir seus trabalhos com possibilidade de prorrogação.

A narrativa midiática tem uma macroestrutura bastante simples, mas chama a atenção pelo comentário escrito: "A expressão do presidente da CPI do Cachoeira, Vital do Rêgo Filho é um retrato do fiasco que se anuncia" e, principalmente, pelo modo visual que se destaca com uma foto ${ }^{9}$ expressiva do presidente da CPI do lado direito do texto multimodal. Consequências, conforme van Dijk (2008) são a parte do texto narrativo que organiza os eventos descritos como decorrentes do evento principal. Na narrativa em foco, porém, as consequências não são mencionadas. Do comentário do narrador jornalista: "A CPI é um fiasco" é possível presumir que não houve consequências, porque provavelmente a CPI não pode concluir o trabalho para o qual foi instaurada. O final feliz característico da fábula é relacionado ao desfecho do evento narrativizado em virtude do modo de recontextualização visual daquela. Além do memorial JK no fundo da imagem, uma escultura do casal Juscelino e Sara Kubitschek aparece no plano intermediário do design que representa o musical inspirado na fábula da Branca de Neve. Os estudos linguísticos distinguem as narrativas ficcionais das narrativas jornalísticas,

\footnotetext{
${ }^{9}$ A credibilidade das narrativas midiáticas (jornalísticas) tem se baseado no conhecimento das fotografias como uma representação naturalista codificada e convencionalizada da realidade, porque elas representam aquilo que é normalmente visível a olho nu (KRESS E VAN LEEUWEN, 2006).
} 
classificando-as por suas diferenças estruturais. Mas, nesse caso, há uma semelhança sutil entre ambas, aplicada, talvez, para ter efeito de curto prazo, devido a interesses políticos e econômicos em jogo.

Concluímos que, se constatadas como verdadeiras as presumidas relações parlamentares com o bicheiro criminoso, os sentidos do texto não contribuiriam apenas para a naturalização do senso de que as relações políticas são contrárias à ética e à ordem social, tão pouco para a indignação coletiva derivada de processos comunicativos que deslegitimam ações como Comissões Parlamentares de Inquérito para investigar ações de membros do Poder Legislativo no Brasil.

Este capítulo elucidou os contextos globais que controlam a produção das narrativas midiáticas consumidas pela sociedade contemporânea, abordando-as em suas distintas características e oferecendo subsídios para análise da macroestrutura do gênero. Um modelo de narrativa midiática multimodal exemplificou o uso de estratégia da ideologia cuja incorporação teve como propósito satisfazer relações de poder e de dominação.

O próximo capítulo aborda os contextos locais da mídia impressa, os modos estratégicos da ideologia incorporados em representações narrativas veiculadas por revistas e os efeitos sociais decorrentes dos significados que veiculam. Em uma perspectiva sócio-histórica, são apresentados os contextos que influenciaram o desenvolvimento da prática jornalística, bem como os contextos institucionais dentro dos quais temas da agenda têm primazia. Estratégias da ideologia operacionalizadas em estruturas narrativas com maior visibilidade e os efeitos de sentidos das narrativas jornalísticas são identificados nesse capítulo com objetivos metodológicos. 


\section{Capítulo 2}

\section{CONTEXTOS LOCAIS, MODOS DA IDEOLOGIA E EFEITOS SOCIAIS}

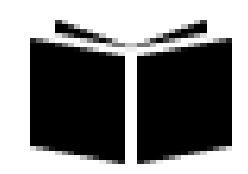

Considerando a existência de interface que liga as narrativas midiáticas às suas situações sociais e comunicativas, este capítulo explana sobre os contextos que, ao longo dos tempos influenciaram as práticas da mídia impressa das quais as semioses são elementos importantes, bem como os contextos institucionais dentro dos quais eventos sociocomunicativos têm primazia. São focalizados os modos da ideologia operacionalizados nas formas simbólicas mediadas pela mídia, identificando-os em narrativas veiculadas em capas de revistas de alcance global. $\mathrm{O}$ capítulo, por fim, detém-se na explicação dos possíveis efeitos produzidos por narrativas políticas e ideológicas sobre a vida em sociedade.

\subsection{Contextos locais}

Os contextos locais são aqui concebidos como modelos sócio-históricos que influenciaram e influenciam a produção tecnológica das formas comunicativas bem como modelos institucionais de produção e de difusão das narrativas impressas mais consumidas pela sociedade contemporânea: jornais diários e revistas semanais.

\subsubsection{Contexto sócio-histórico}

A comunicação social realizou-se em todos os estágios de evolução humana, desde as primeiras formas rupestres, passando pelas formas de impressão monomodais até às formas tecnológicas de comunicação contemporâneas, de modo que a necessidade do ser humano pelo ato de comunicar tem sido satisfeita. $O$ crescente desenvolvimento do homo sapiens e, por conseguinte, dos meios de 
produção e de reprodução das formas simbólicas levou ao aumento crescente do número de informações e das formas de repasse de tais informações.

Os impressos são os meios de comunicação que há mais de 2000 anos divulgam informações de interesse político, econômico e social. Em 59 anos a.C., o primeiro jornal do mundo, denominado Acta Diurna, já informava o povo romano sobre conquistas militares, políticas e científicas. Magistrados e servidores públicos, enviados a todas as regiões e províncias romanas, acompanhavam de perto os acontecimentos políticos, recolhiam as informações e redigiam-nas em forma de narrativas. Nas oficinas do Estado e de editoras privadas, os textos manuscritos eram copiados por escribas e impressos em grandes placas de papel e de madeira para serem lidos em praça pública.

\section{Figura $20^{10}$ - Impressão do Acta Diurna}

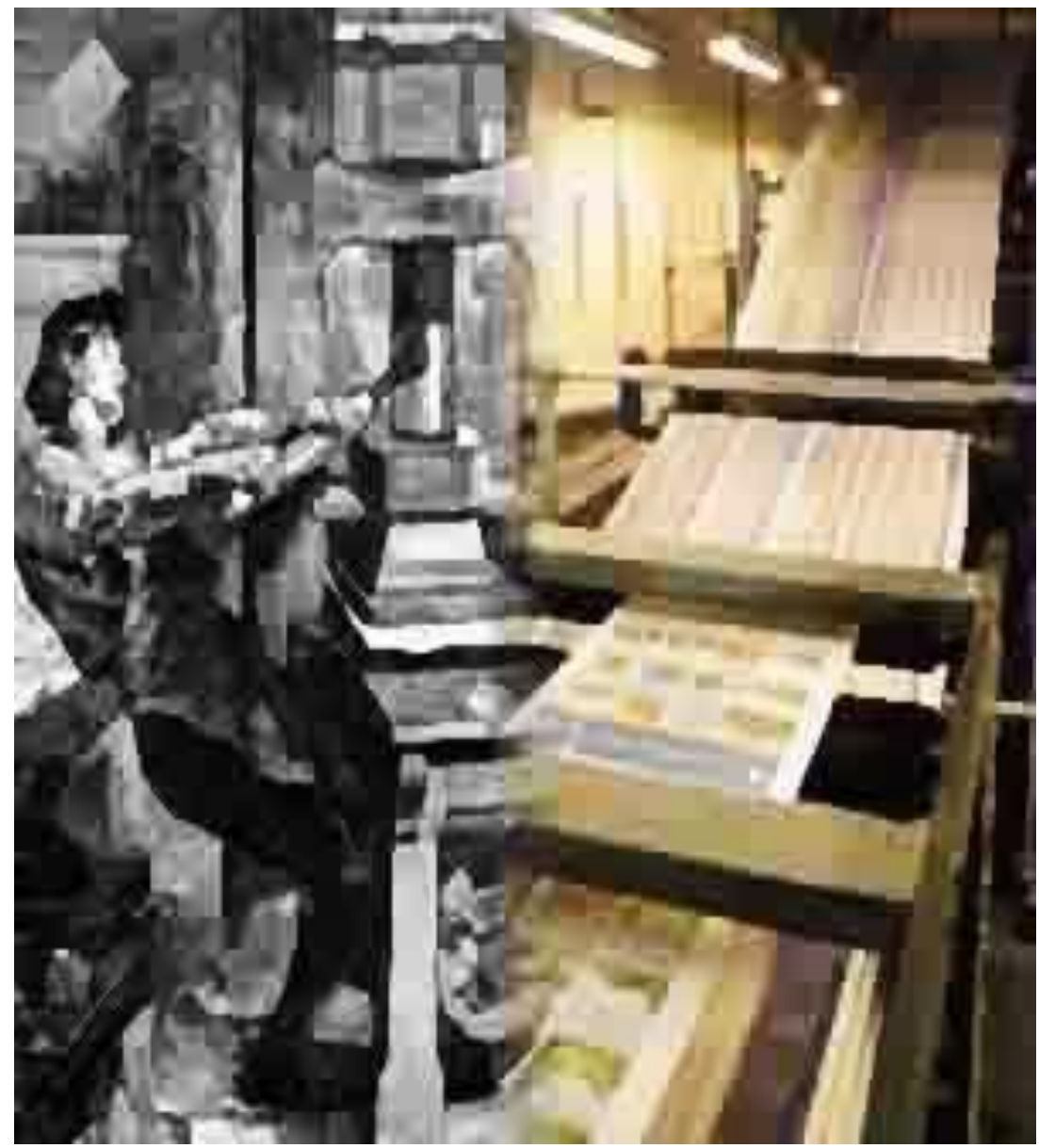

Fonte: $<$ http://www.guiadacarreira.com.br>.

\footnotetext{
${ }^{10} \mathrm{~A}$ imagem da Figura 20 corresponde à forma on-line disponível na fonte acima especificada.
} 
O Acta Diurna, o mais antigo jornal do mundo, era exposto para ser lido gratuitamente pelas pessoas. Desde aquele tempo, a primeira mídia jornalística do mundo já servia ao poder, ao Império Romano, com atualização e periodicidade de informações.

A imprensa de Gutenberg em 1450, método de duplicar a fundição das letras de metal, foi o meio de produção que permitiu combinar volumosas e extensas composições textuais ${ }^{11} \mathrm{com}$ a técnica da prensa de parafusos. Aperfeiçoado, este método de impressão permaneceu em uso por mais de três séculos (THOMPSON, 2012, p.86).

Figura 21 - Imprensa de Gutenberg

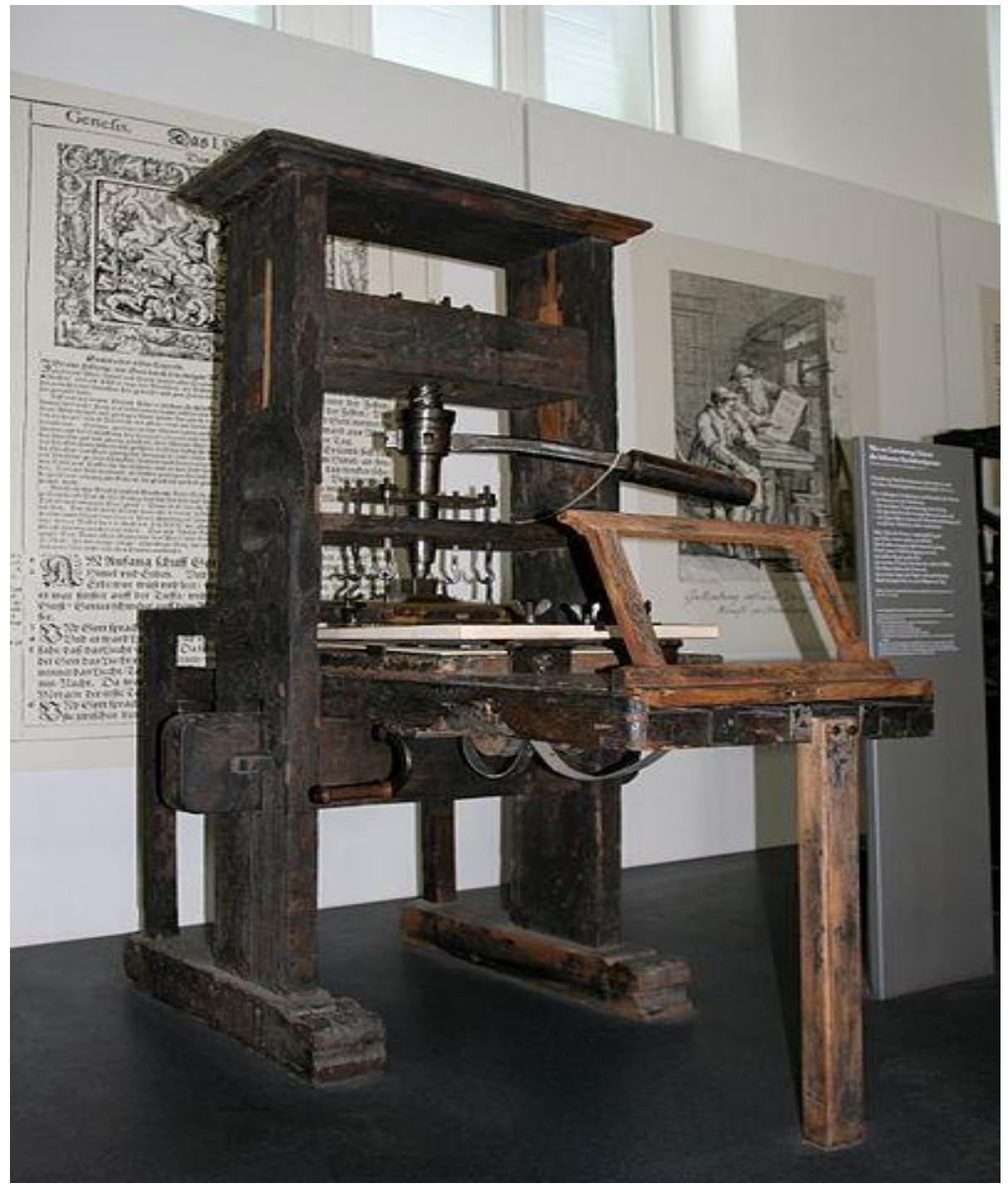

Fonte: <http://pt.wikipedia.org/wiki/Ficheiro:Handtiegelpresse_von_1811.jpg>.

\footnotetext{
${ }^{11}$ A Bíblia, o primeiro livro impresso com a tecnologia da prensa mecânica de papel, foi lançada e vendida, e depois, uma grande quantidade de livros foi sendo impressa em línguas vernáculas.
} 
Era da Renascença, a propagação da informação impressa ganhou impulso fabuloso. Acontecimentos sociais, políticos e econômicos passaram a ser registrados em papéis que circulavam nas áreas mais habitadas de cada país. Mas a imprensa periódica era vista por autoridades do Estado como prejudicial ao Governo dependente do crescimento de uma economia moderna. Na Inglaterra, a lei que impôs aos impressos o pagamento para circular de notícias fez aumentar o preço do exemplar e diminuir a sua venda. Na França, todo o conteúdo do jornal era supervisionado por uma organização corporativa antes de ser publicado. $\mathrm{Na}$ Alemanha, assim como em outros países, o controle rigoroso do Estado levava à publicação assuntos de pouca relevância.

Com a necessidade de regulamentar a atividade profissional surgiu 0 conceito de Liberdade de Imprensa. A Suécia foi o primeiro País do mundo a implementar a Liberdade de Imprensa. Por meio de uma lei criada no ano de 1766 , foi garantido o direito de os profissionais de jornalismo e os jornais da Suécia publicar informações reais. Contudo, somente após a Revolução Francesa (1789_ 1799), quando inúmeros fatos despertaram a curiosidade das pessoas, e mais propriamente após a Revolução Industrial (1820 e 1840), quando o processo de mecanização tornou a impressão mais rápida e econômica, os impressos do mundo buscaram demonstrar sua função social. A evolução da imprensa em bases comerciais e independentes foi capaz de fornecer informações e comentários críticos sobre questões de interesse geral.

Nos Estados Unidos, o progresso da imprensa privada popularizou o jornal sensacionalista, o qual expunha em primeira página textos com conteúdos de caráter social. Nessa ocasião, as páginas de jornais norte-americanos monomodais passaram a ter ilustrações. O pleno desenvolvimento da imprensa americana, entretanto, era impedido pela enorme extensão territorial do país. Uma saída para tal dificuldade foi a criação de agências que estendiam informações locais em âmbito nacionais com o controle de centenas de jornais. Mas a crise de 1929 abalou a economia nacional e vetou tal êxito.

No período pós-industrilização, a Inglaterra inovou produzindo jornais com uma maior variedade de assuntos - notícias, informações esportivas e de interesse feminino com modelos de primeira página melhor definido. A França passou a ter jornais de esquerda, de centro e de direita, e de estilos e orientações diversas. A 
Alemanha não operou mutações muito relevantes, mas suas folhas ganharam uma paginação com um conteúdo mais rico e variado.

As revistas, até 1830, eram um produto de elite consumido pelas classes mais altas e de formação escolar avançadas. No Brasil, a Revista Illustrada, uma publicação semanal de distribuição nacional satírica, política e abolicionista, foi inovadora por sua diagramação ilustrativa e litografia expressa. Nos 22 anos contínuos (de 1876 a 1898) em que foi publicada, a Revista Illustrada inspirou uma geração de revistas satíricas.

A abolição da liberdade de expressão pela Constituição Brasileira de 1937 levou a imprensa a uma rigorosa censura que vigorou durante o período em que Getúlio Vargas governou o Estado Novo. Mas, a incompatibilidade de Vargas com a imprensa, contrária ao seu regime, contribuíram para a queda do Presidente. Em 1945, após reclamar a plena liberdade para as eleições que se anunciavam, o Globo lançou publicamente a candidatura do brigadeiro Eduardo Gomes à presidência da República. Nos meses seguintes, vários fatores contribuíram para uma crise que culminaria em outubro com a queda de Vargas e o fim do Estado Novo. Quando a liberdade de imprensa ${ }^{12}$ foi garantida no Brasil, os jornais comerciais prósperos buscavam penetrar em todos os meios para aumentar o valor de sua publicidade e empregar sua influência na orientação da opinião pública; o que demostrou a poder da mídia sobre a opinião pública.

O jornalismo no mundo teve outro salto tecnológico com a invenção do Telégrafo, que permitiu repassar os textos jornalísticos às redações em questão de minutos. Conhecida como Era de Ouro dos Jornais, os impressos chegaram ao século XX no auge do seu prestígio e popularidade. Revistas também marcaram épocas e gerações inapagáveis. Capas da revista Esquire, por exemplo, perduram como um registro atemporal.

\footnotetext{
${ }^{12}$ Atributo fundamental dos regimes democráticos, a liberdade de impressa significa a liberdade de acesso e de divulgação de informações sem censura prévia ou ostensiva dos órgãos estatais.
} 
Figura 22 - Richard Nixon

Revista Squire, maio de 1968

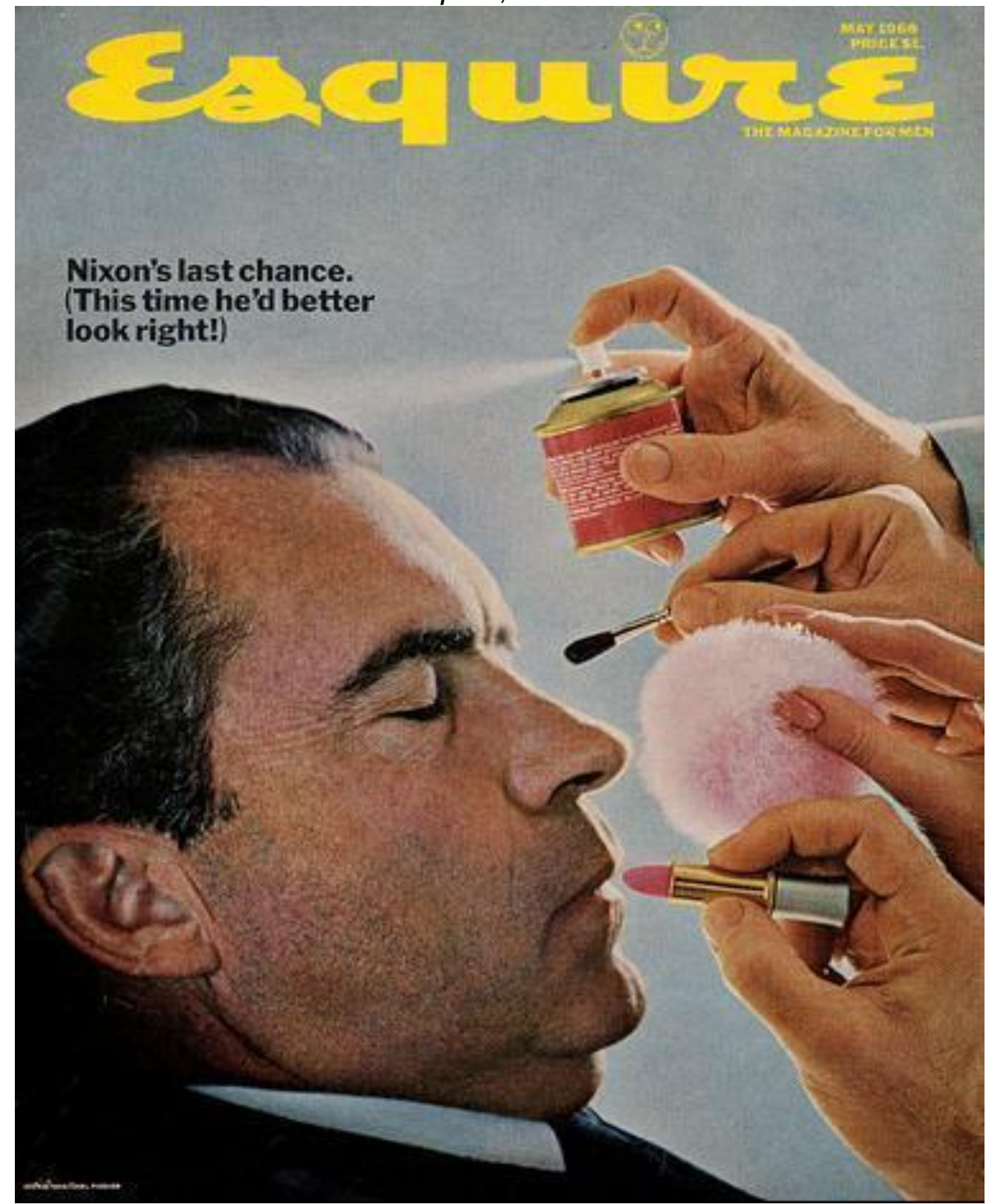

Fonte:<https://freakshowbusiness.wordpress.com/2009/02/19/as-melhorescapas-da-revista-esquire-nos-anos-60/>.

A chegada do rádio, porém, fez a atividade do jornalismo tradicional começar a declinar. Mas a publicação em larga escala de fotos coloridas em textos produzidos em uma linguagem mais popular e a abertura de espaços para o esporte e o humor permitiu o jornalismo tradicional chegar à atualidade. A crise dos impressos tornou-se visível a partir de 1970, quando os índices de leitura e de circulação começaram a cair e quando a hegemonia do jornalismo clássico começou a dar lugar à Televisão, principal meio de mídia do mundo. 
A situação dos impressos agravou-se a partir dos anos 1990, com a crescente popularização da internet como ferramenta de comunicação. O que antes era atribuído basicamente a uma questão editorial tornou-se, no final da década, um problema financeiro estratégico, porque os portais informativos on-line passaram a atrair os leitores e os anunciantes da mídia impressa. O quadro a seguir demonstra a linha de evolução do jornalismo impresso, do período de 69 a.C. ao ano de 1879 , passando pela Era de ouro e auge dos impressos (1890-1921), até o ano de1921, quando surgem as novas mídia:

Quadro 2 - Linha de evolução do jornalismo impresso: crescimento, auge e declínio

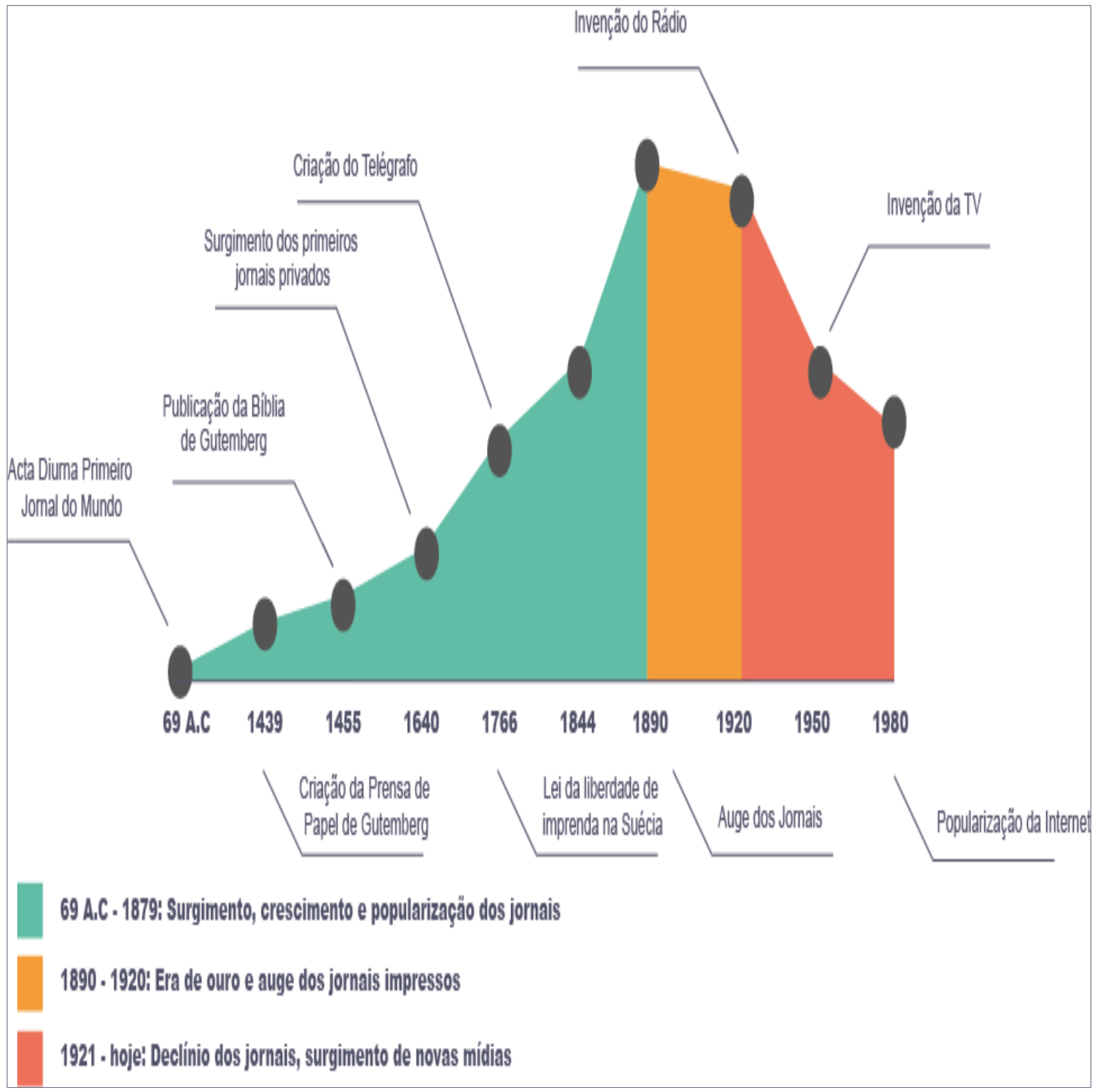

Fonte: $<$ https://www.guiadacarreira.com.br> (adaptado). 
Jornalismo praticado na internet tem como principais características a agilidade da linguagem, a velocidade de atualização e o baixo custo de produção. No ano de 1990, havia aproximadamente 1000 sites (esse número está, atualmente, na casa dos bilhões. A internet é definitivamente a nova grande mídia que está oferecendo oportunidades aos profissionais de jornalismo (CASTILHO e FIALHO, 2013).

A World Association of Newspapers (WAN), associação que cuida da atividade de jornalismo no mundo, calcula que, aproximadamente, 900 milhões de pessoas leem jornais e revistas diariamente, principalmente no Japão e na China, onde o hábito de ler é forte. Apesar de o índice de leitura no Brasil ser menor ${ }^{13}$, levantamento da tiragem de revistas brasileiras realizado pela Associação Nacional dos Servidores Efetivos das Agências Reguladoras Federais (ANER) indica o crescimento no consumo das revistas, por classe social. $O$ quadro a seguir representa o resultado estatístico:

Quadro 3 - Consumo do meio impresso por classes sociais

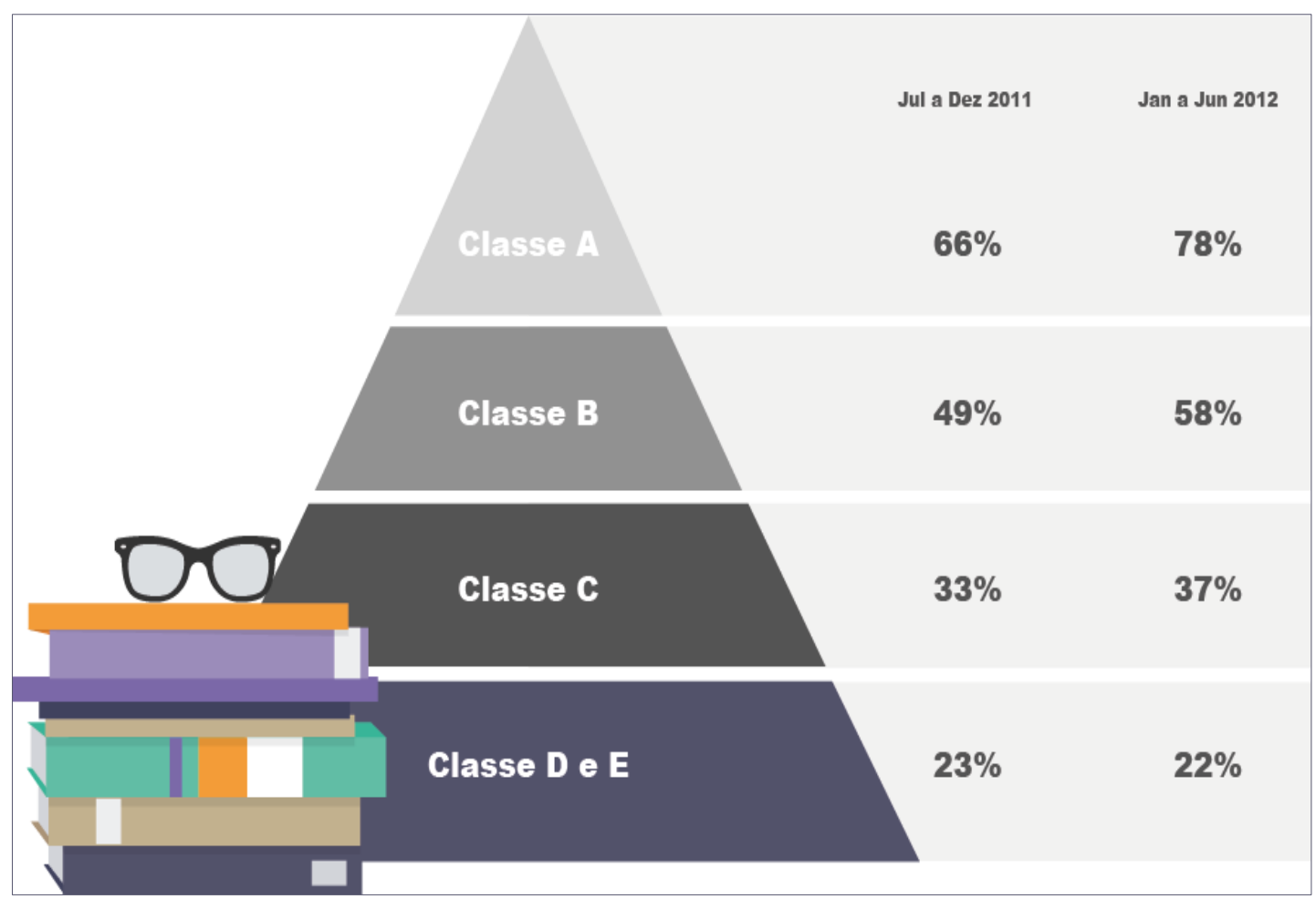

Fonte: Ipsos - Estudos Marpla.

\footnotetext{
${ }^{13}$ Retrato da Leitura no Brasil realizada pelo Instituto Pró-livro em parceria com o lbope inteligência revela que o brasileiro está lendo mais.
} 
Os impressos do Brasil apresentam as informações com maior nível de confiança quando comparados ao rádio, à TV e à internet. De acordo com o levantamento providenciado pela Secretaria de Comunicação da Presidência da República (SECOM), em 2014, 53\% dos entrevistados que usam os jornais afirmaram confiar nas narrativas editoriais e $40 \%$ nas reportagens de revistas. Assim, para manter seus espaços editoriais em função dos noticiários de TV e da redução das receitas de anúncios, a imprensa brasileira fez importantes transformações no que diz respeito à reelaboração de sua linguagem gráfica e de seus textos. Os meios impressos reinventam-se e continuam ocupando um espaço de grande destaque no mundo, sendo a segunda principal mídia atrás apenas da televisão.

Mas, as novas técnicas da imprensa, caracterizadas pelo desejo de ampla difusão, geram a universalização de valores éticos e culturais com reflexos no comportamento humano. Alguns eventos relatados pela mídia podem até ser experimentados como exteriores e remotos, mas essa difusão exerce tanta influência na consciência cotidiana e nas atividades humanas, que o comportamento humano torna-se padronizado. Isso implica que, além do impacto das novas tecnologias digitais sobre os gêneros e do controle hegemônico sobre a produção das formas simbólicas, desafios são impostos aos gêneros da mídia impressa para continuarem sendo consumidos.

\subsubsection{Contextos institucionais da mídia impressa}

O desenvolvimento e a expansão das instituições contemporâneas e da própria mídia está diretamente envolvido com o imenso aumento da mediação da experiência que as formas de comunicação desenvolveram. Atualmente, os materiais impressos - jornais e revistas on-lines - atravessam o espaço tão facilmente que podem ser lidos e distribuídos simultaneamente. A palavra impressa é um fenômeno global devido a sua integração e convergência com a palavra eletrônica. Os jornais e as revistas são tanto a expressão das tendências globalizantes, quanto instrumento dessas tendências (GIDDENS, 2002, p. 31).

Os contextos institucionais aqui expostos abrangem meios de comunicação impressos cujo posicionamento político é conhecido por seu público consumidor: o 
Correio Braziliense, jornal diário de circulação nacional, e as revistas semanais: Veja e Isto é. As revistas americanas Time, Newsweek e The Economist, todas de circulação nacional e internacional, são tomadas como exemplo.

A escolha desses modelos de contexto institucionais justifica-se. O Correio Braziliense, por ser um impresso crítico, mas premiado por seu design gráfico. As revistas semanais mencionadas, porque são notadamente, os meios de comunicação que chamam a atenção do público leitor, por suas estéticas e persuasivas publicação de capas e de páginas multimodais.

\subsubsection{Correio Braziliense ${ }^{14}$}

\section{Correio BraZiLIense}

O primeiro número do Correio Braziliense foi veiculado em Londres em junho de 1808, poucos meses antes da circulação da Gazeta do Rio de Janeiro. Editado por Hipólito José da Costa, com o subtítulo "Armazém Literário", o jornal foi criado para apontar os problemas da administração do Brasil e difundir suas ideias entre os formadores de opinião, mas tinha um caráter mais doutrinário do que informativo.

Fundado no dia 21 de abril de 1960 por Assis Chateaubriand, o impresso teve matérias censuradas e apreendidas pelo governo, mas tornou-se um impresso de repercussão nas camadas mais esclarecidas. Após associar-se ao maior conglomerado de mídia no Brasil, os Diários Associados, o Correio foi lançado como um novo jornal na Capital do Brasil, ao lado da Folha de S. Paulo, do Estado de Minas, de O Globo e de O Estado de S. Paulo. Atualmente, o Correio Braziliense forma o grupo dos principais jornais brasileiros.

Premiado por seu jornalismo e conhecido por editar manchetes criativas independentes sobre poder, o jornal movimenta o mercado jornalístico, fortalecendo a estrutura dos Diários Associados. O estímulo à competitividade à privatização das empresas, à valorização da globalização e à movimentação da economia ao consumo são características ideológicas desse jornal.

\footnotetext{
${ }^{14}$ Disponível em: <http://pt.wikipedia.org/wiki/Correio_Braziliense>.
} 


\subsubsection{Revista Veja}

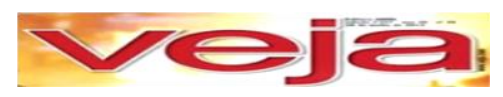

A $V_{e j a}{ }^{15}$ é uma revista brasileira de ampla circulação nacional, com uma tiragem superior a milhão de exemplares, sendo oitocentos mil assinantes e o restante vendido em bancas. A publicação trata com frequência de questões políticas, econômicas, culturais, mas também de outros assuntos. Fundada nos anos de 1960, como uma revista de tendências centristas e centro-esquerdistas, a partir de 1990, a revista foi gradativamente se alinhando às ideias tradicionalmente associadas ao liberalismo econômico e às políticas de direita. Suas reportagens têm exercido papel relevante na divulgação de crises políticas de grandes proporções, mas também tem sido amplamente criticada por seu posicionamento político junto ao de alguns setores conservadores da direita política brasileira, e pelo uso de métodos considerados pouco jornalísticos de fazer reportagens. A denúncia de fatos públicos e graves e a presunção de culpa dos denunciados a fazem alvo de críticas de partidos políticos, de políticos, de jornalistas e de setores da sociedade. Embora condenada em alguns processos judiciais, a revista foi absolvida em outros.

Estudo intitulado "Vozes de um mundo distante" realizado por Luz (2013) sobre uma matéria de capa da revista $\mathrm{Veja}^{16}$ averiguou se a publicação da matéria havia adotado as regras do jornalismo: apuração dos fatos, uso de fontes credenciadas, isenção, busca da verdade, manifestação dos citados na matéria e respeito à privacidade das pessoas. A análise demonstrou a intenção de a revista desqualificar congressistas por meio do uso de adjetivos e de metáforas, de ironias em excesso e de mostrar uma solução imagética para o problema. A análise mostrou que em vez de criticada, uma proposta parlamentar defendida por especialistas deveria ter sido valorizada por sua legalidade e justeza. O estudo de Luz (2013) conclui que a imprensa tem a função de fiscalizar e de fazer a crítica aos poderes, não a de ridicularizar adversários políticos.

\footnotetext{
${ }^{15}$ Revista Veja. Disponível em:<http://www.observatoriodaimprensa.com.br/news/view>.

${ }^{16}$ Veja, edição de número 2.329, de 10/7/2013. Disponível em: <http://veja.abril.com.br/acervodigital>.
} 
De acordo com um dossiê da Veja ${ }^{17}$, a estrutura da revista é centralizada. Os diretores controlam equipes e definem conteúdos de capa. Eventualmente o editor-executivo de área participa das reuniões do Conselho. Embora tenham conhecimento, competência profissional e estejam alinhados com a editora, o editor e o jornalista não decidem sobre o que será publicado. As informações podem surgir de uma agenda mantida com empresas transnacionais e com funcionários do Palácio do Planalto. A posição da Veja é claramente conhecida, mas questionamentos éticos aparecem quando as relações por trás de interesses políticos e econômicos não são transparentes.

A concentração dos veículos de comunicação nas mãos de poucos grupo é a marca da história da mídia no Brasil. O grupo Abril abarca um complexo que envolve 90 revistas, duas editoras de livros (Ática e Scipione), uma rede de TV (MTV), uma de TV a cabo (TVA) e uma rede de distribuição de revistas em bancas de jornal, além de inúmeras páginas na internet. A Veja é a quarta revista com maior tiragem no mundo. Um levantamento das capas da revista nos anos de 2000, 2002 e 2005 mostra que a política interna e a economia são os temas mais frequentes.

\subsubsection{Revista ISTO É ${ }^{18}$}

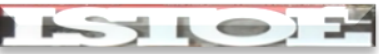

A ISTO É é uma importante revista semanal divulgadora de informação e formadora de opinião pública que sempre desafiou o poder para manter a sua fidedignidade com os seus leitores. Seu primeiro exemplar chegou às bancas em 1976, em época de ditadura, propondo deixar claro que o regime presente visava ao controle e ao silenciamento da verdade. Embora suas reportagens retratem assuntos variados, são traduzidos com textos, ilustrações e fotos pequenas, inclusive, em trechos finais de matérias para as últimas páginas. A revista mantémse em sua linha editorial de esquerda, sendo uma das mais respeitadas do país ${ }^{19}$.

\footnotetext{
${ }^{17}$ Dossiê Veja. Disponível em: <http://www.novae.inf.br/site/modules.php?name=Conteudo\&pid=330>. Laboratório de invenções da elite, por Anselmo Massad, da revista Fórum.

${ }^{18}$ Disponível em: <http://pt.wikipedia.org/wiki/ISTOÉ>.
} 


\subsubsection{Revista Time ${ }^{20}$}

\section{TIME}

A Time, uma das revistas de notícias dos Estados Unidos, é a mais conhecida e de maior circulação do mundo. A primeira edição da Time, publicada em 3 de março de 1923, inventou o conceito de revista semanal de notícias. Sua principal característica é a nomeação de Pessoa do Ano, realizada há mais de 80 anos. A revista Time reconhece o indivíduo, ou o grupo de indivíduos que obteve o maior efeito no ano. Mas, quem já recebeu o título, de Pessoa do Ano foi o OIBM PC/AT, um computador pessoal.

\subsubsection{Revista Newsweek ${ }^{21}$}

\section{NeW'Week}

A Newsweek foi criada em 1933 e ganhou destaque na década de 1960 por sua cobertura dos movimentos de defesa dos direitos civis. É a segunda maior revista semanal editada e produzida nos Estados Unidos, superada apenas pela revista Time em circulação e em ganhos com publicidade. A Newsweek traz atualidades do mundo e tendências internacionais nas áreas de saúde, tecnologia, ciência, lifestyle, negócios, política e economia. No decurso dos anos, desenvolveu um vasto material de notícias, de grandes histórias e de análise de comentários.

A Newsweek tem sido considerada como a revista mais liberal das três maiores revistas semanais americanas. O corpo de jornalistas chegou ao número de 300 com mais de 3 milhões de leitores em 193 países. Mas, devido à queda no número de leitores e na receita com publicidade, a partir de 2013, a Newsweek deixa de circular em papel tornando-se uma publicação digital.

\footnotetext{
${ }^{20}$ Disponível em: <http://pt.wikipedia.org/wiki/Time_(revista)>.

${ }^{21}$ Disponível em: <http://pt.wikipedia.org/wiki/Newsweek>.
} 


\subsubsection{Revista The Economist ${ }^{22}$}

\section{The
Economist}

The Economist é uma publicação inglesa de notícias políticas e econômicas e de assuntos internacionais de propriedade da The Economist Newspaper Ltda. Desde a sua fundação, em setembro de 1843, a revista é continuamente publicada. Editada semanalmente em sua sede na cidade de Londres, no Reino Unido, referese a si mesma, por razões históricas, como um jornal, mas cada edição é impressa em formato de revista de notícias. Em 2006, metade de sua circulação média semanal, cerca de 1,5 milhões de exemplares, foi vendida nos Estados Unidos.

A publicação pertence ao The Economist Group, por meio do Financial Times, e a um grupo de acionistas independentes, incluindo membros da família Rothschild, de banqueiros ingleses. O conselho de administração nomeia formalmente o editor da revista, que não pode ser removido sem a sua permissão. A revista de alcance global tem como ideologia o liberalismo clássico e econômico, o livre-comércio, a globalização, e apoia a imigração livre e algumas causas socialmente liberais. O público alvo da revista, leitores qualificados, executivos influentes e líderes políticos, é fiel. Alguns dos leitores da publicação consomem tanto a mídia de massa quanto a da elite. A The Economist descreveu que essa mudança global, notada pela primeira vez na década de 1990, acelerou-se no início do século XXI, como uma nova era da inteligência de massa.

O conhecimento dos aspectos contextuais abordados anteriormente são importantes, porque os dados da análise levada a efeito foram extraídos dos periódicos mencionados. Narrativas multimodais publicadas em capas suportes de algumas das revistas mencionadas são focalizadas no próximo tópico porque incorporam estratégias da ideologia cujos modos não são transparentes ao público consumidor.

\footnotetext{
${ }^{22}$ Disponível em: <http://pt.wikipedia.org/wiki/The_Economist>.
} 


\subsection{Modos estratégicos de operação da ideologia}

O conceito de ideologia proposto por Thompson (2011) refere-se às maneiras como os significados materializados nas formas simbólicas criam e instituem relações de poder e de dominação, através de um contínuo processo de produção e de recepção dessas formas. Nessa perspectiva crítica a ideologia é vista como um processo operacionalizado nos textos multimodais em circunstâncias sócio-históricas particulares.

É sob um verniz retórico escolhido e sob a ilusão da criatividade autônoma, do mascaramento das relações sociais e do obscurecimento da falsa interpretação de situações, que a ideologia age nas formas de (inter)ação, de representação e de identificação da realidade. Isso indica a existência de um sistema de meios e de fins operando em caráter global em conformidade com as condições e com circunstâncias econômicas e políticas do nosso tempo.

Para Thompson (2011, p.78) os modos de operação da ideologia são significativos porque servem, em circunstâncias sócio-históricas específicas, para manter e sustentar relações de poder e de dominação. Se eles estabelecem e sustentam essas relações é uma questão que pode ser respondida somente quando se analisa os textos. Os modos da ideologia não são únicos, nem independentes entre si. Eles podem sobrepor-se e reforçar-se mutuamente em textos concretos de maneira que seus efeitos influam na reprodução da ordem social. Cada modo possui estratégias típicas de construção de sentidos. Tendo em vista o intuito de analisarmos como a ideologia operada nas narrativas mais consumidas pelo público e os efeitos que essas formas produzem na vida em sociedade, procuramos identificá-la em representações narrativas veiculadas em suportes dos modelos institucionais mencionados.

O quadro a seguir mostra os principais modos da ideologia e as estratégias típicas de operacionalização de cada modo, identificando-as e exemplificando como elas podem ser incorporadas em narrativas midiáticas multimodais difundidas nos suportes mais visíveis de revistas de alto consumo: 
Quadro 4 - Modos de operação da ideologia

\begin{tabular}{|l|l|l|l|l|}
\hline MODOS GERAIS & ESTRATÉGIAS TíPICAS DE CONSTRUÇÃo SIMBÓLICA \\
\hline LEGITIMAÇÃO & Racionalização & Universalização & Narrativização & \\
\hline DISSIMULAÇÃO & Deslocamento & Eufemização & Tropo & \\
\hline UNIFICAÇÃO & Padronização & $\begin{array}{l}\text { Simbolização da } \\
\text { Unidade }\end{array}$ & \\
\hline FRAGMENTAÇÃO & Diferenciação & $\begin{array}{l}\text { Expurgo do } \\
\text { outro }\end{array}$ & \\
\hline REIFICAÇÃO & Naturalização & Eternização & Nominalização & Passivização \\
\hline
\end{tabular}

Fonte: Thompson. Ideologia e Cultura Moderna. 2011, p. 81.

\subsubsection{Legitimação}

A legitimação, de acordo com Thompson (2011, p. 83), é um modo estratégico de operação da ideologia estabelecido e mantido por fundamentos racionais, tradicionais e carismáticos expressos por construções simbólicas representadas como legítimas que fazem apelo à legalidade de regras, às tradições imemoriais e ao caráter excepcional de uma autoridade. A racionalização, a forma mais explícita desse modo, envolve a construção de uma cadeia de raciocínio em que o produtor defende um conjunto de instituições sociais e relações sociais de modo persuasivo para convencer os seus receptores de que isso é digno de apoio etc. A universalização, outra estratégia de legitimação, apresenta acordos institucionais como se necessários e abertos, muito embora esses sirvam aos interesses daqueles que tendem a firmá-los e que possuem a habilidade de torná-los bem-sucedidos. As exigências de legitimação também podem ser satisfeitas pela narrativização, importante modo de operação estratégico da ideologia inserido em formas simbólicas que expressam o presente como se esse fizesse parte de uma tradição eterna e dignificante. A representação narrativa da revista Veja exemplificaa claramente. 
Figura 23 - Manifestação popular

Veja, 20 de junho de 2013

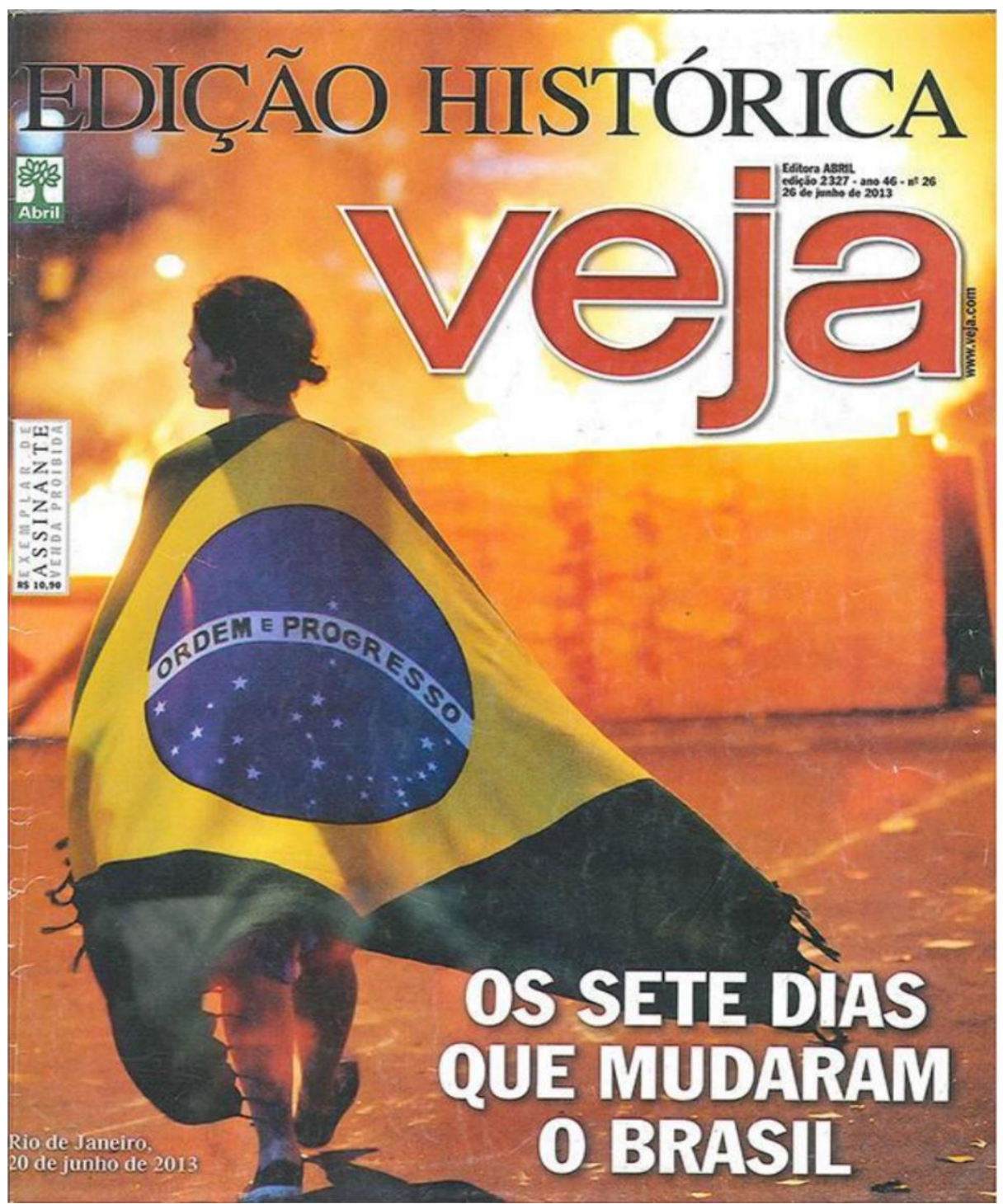

Fonte: Edição 2.327, ano 46, n. 26.

Essa não uma representação neutra do evento narrado, pois, como sabemos, é impossível realizar grandes mudanças em apenas sete dias. Entretanto, o leitor da narrativa, influenciado tanto por aquilo que o texto evoca, quanto por sua própria leitura e pelas manipulações da história, lê o texto narrativo, não a fábula que permanece como traço em sua memória. Os sentidos que essa narrativa multimodal evoca sobre os jovens são diferentes dos textos jornalísticos que, em sua maioria, denominaram de 'vândalos' jovens que participaram do movimento contra abusos da dominação econômica e do poder político. 


\subsubsection{Dissimulação}

A dissimulação, modo de operação estratégico que oculta ou obscurece relações de poder e dominação, pode ser expressa por formas de deslocamento, de eufemização e por figuras linguagem - metáfora, metonímia e sinédoque. O deslocamento, termo usado para se referir a outro, é uma estratégia dissimulatória que oculta realidades novas reativando sentidos com conotações positivas. A eufemização realiza-se pela mudança sutil ou pela supressão dos sentidos negativos, a fim de despertar uma valoração positiva de instituições, de relações sociais e de ações particulares. A dissimulação da ideologia pode ser expressa por figuras de linguagem: pela sinédoque, uso de um termo que compreende uma parte do todo para se referir ao todo ou que compreende o todo para se referir a uma parte; a metonímia, que consiste no uso do atributo de alguma coisa para referir-se à própria coisa, podendo o referente ser avaliado de forma positiva ou negativa; e a metáfora que implica o uso de um termo de outro campo semântico a um objeto ou ação, ao qual o termo em seu sentido literal não poderia ser aplicado (THOMPSON, 2011, p. 83). A representação a seguir exemplifica:

Figura 24 - Manifestação popular

Veja, 19/01/2013

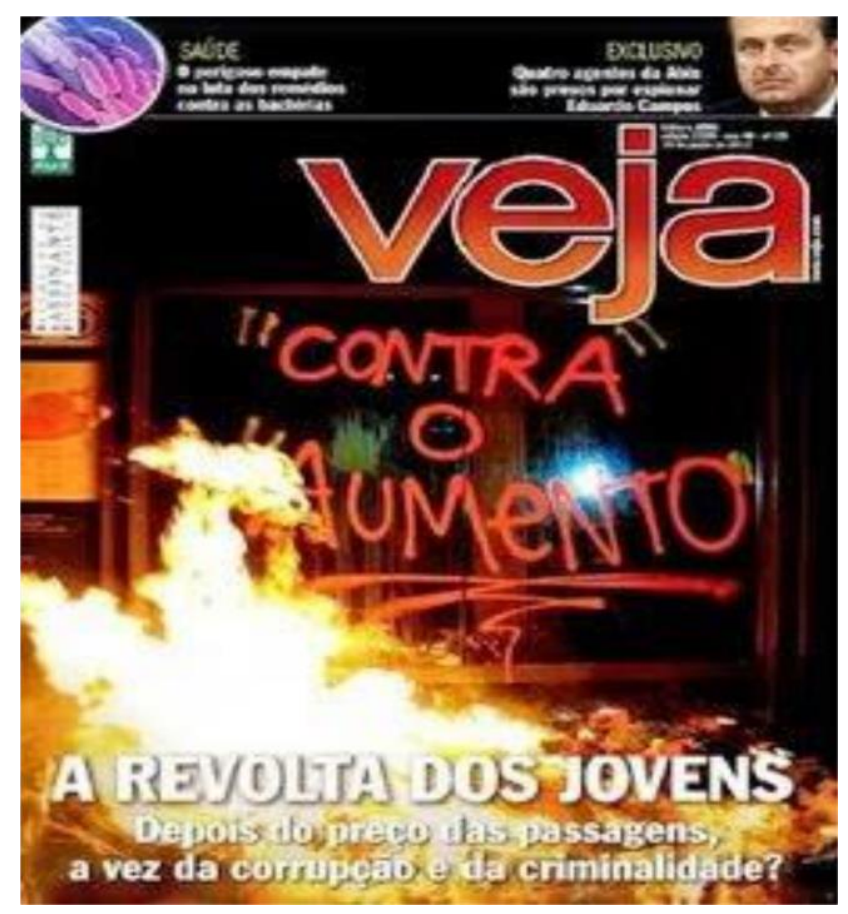

Fonte: Edição 2.326, ano 46, n. 25. 
O texto veiculado desencoraja os jovens de participar do movimento popular contra os abusos do poder econômico e político e também os responsabiliza pelas consequências do fogo ateado por poucos manifestantes inconsequentes. A expressão metafórica CONTRA O AUMENTO, que aparece subposta ao fogo e grafada em fonte vernacular não convencional (não personalizada) remete à ação do povo, podendo sugerir o sentido de que a oposição ao aumento não é legítima.

Embora a expressão metonímica A REVOLTA DOS JOVENS (atributo de uma parte representando o todo) pareça ter conotação positiva, seu significado é contraditório. O texto dissimula a verdadeira causa do desencadeamento das manifestações, neutraliza a legitimidade do poder popular contrário ao aumento e à corrupção e confunde o leitor quanto à verdadeira agência da criminalidade. Nesse caso, a criminalidade a que o texto se refere não está clarificada.

\subsubsection{Unificação}

O terceiro modo de operação da ideologia descrito por Thompson (2011, p. 83) é a unificação, isto é, a construção simbólica de uma forma de unidade que une e interliga os indivíduos em uma identidade coletiva, independente das diferenças e das divisões existentes entre eles. Um das estratégias de unificação é a padronização. O texto, abaixo, a exemplifica.

Figura 25 - Partido dos Trabalhadores

ISTO É, 19 de junho de 2012

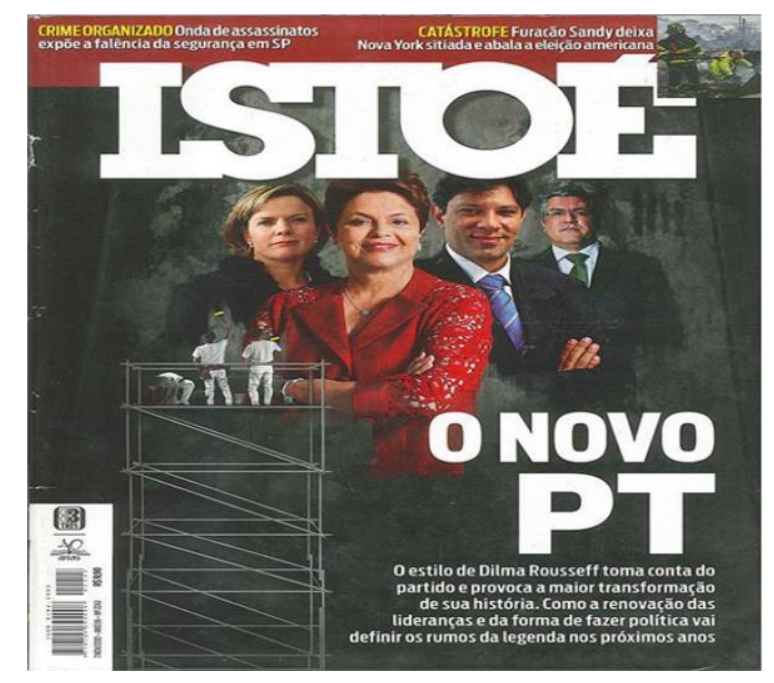

Fonte: Edição 2.326, ano 46, n. 25. 
Representado como fundamento partilhado por autoridades de Estado, o referencial promovido pela forma simbólica liga os indivíduos a um ponto de vista que defende uma identidade aparentemente nova. $O$ ângulo alto e a postura dos participantes representados expressam poder e conhecimento. Os significados da representação são persuasivos no sentido de que o referencial expresso pelo modo dos participantes da estrutura narrativa visual (postura) deve ser aceito, adaptado e seguido por todos.

A simbolização, estratégia mais típica da unificação, envolve o uso de bandeiras, de hinos nacionais, de emblemas e de inscrições de vários tipos. Relacionada à narrativização, a simbolização tem potencial efeito de sentido, pois as histórias dignificantes projetam destinos coletivos. A representação narrativa da edição histórica da revista Veja, a seguir, incorpora a simbolização de unidade como estratégia para unir os brasileiros em uma única identidade

Figura 26 - Manifestação popular

Veja, 20 de junho de 2013

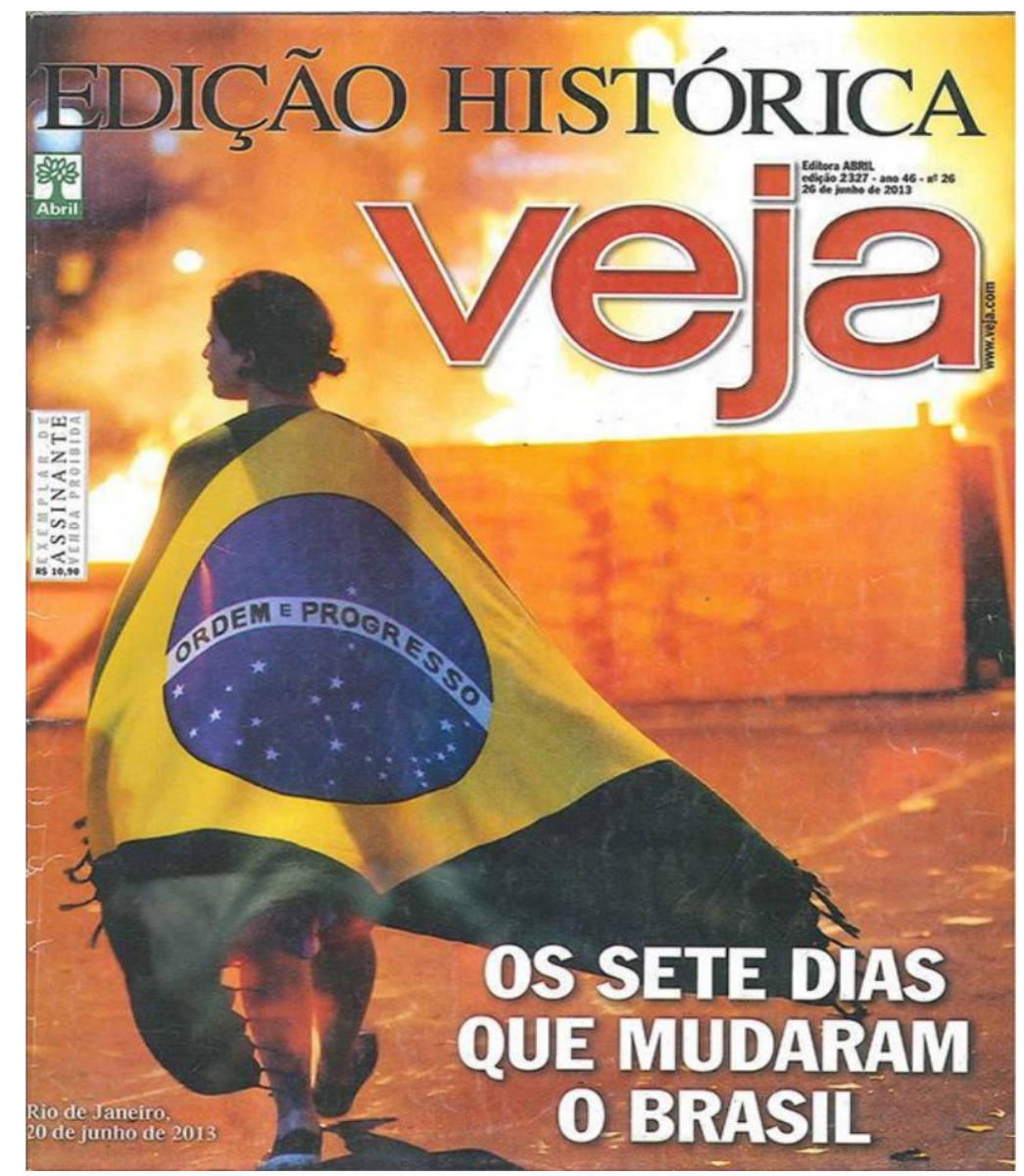

Fonte: Editora Abril, edição 2.327, ano 46, n. 26. 
Nessa narrativa, a bandeira do país funciona como recurso semiótico para a sustentação do argumento: OS SETE DIAS QUE MUDARAM O BRASIL. Todavia, não há um curso de ação que comprove que houve uma mudança real no país. Os textos com cenas de violência difundidos anteriormente pela grande mídia contradizem o argumento prático.

Os sentidos da quase narrativa política evidenciam que o movimento foi exitoso, que o ideal democrático foi alcançado, ainda que a realidade os contradigam. A narrativa poderia representar o ideal como resultado de uma democracia revitalizada. No entanto, em contexto de crise financeira e moral como a que vive o Brasil, a representação não expressa o real. O conhecimento partilhado cotidianamente por especialistas sobre a crise financeira mundial leva à pressuposição de que a forma midiática consiste em uma tentativa de controle social e de retorno do status. A naturalização da falsa crença pode servir para evitar uma repetição do movimento, mas não pode garantir que os sentidos do texto tenham efeito de longo prazo.

\subsubsection{Fragmentação}

O quarto modo de operação da ideologia (THOMPSON 2001, p. 87), por meio do qual as relações de poder e de dominação podem ser mantidas, é a fragmentação. Esse modo tem como principal estratégia a diferenciação, uma estratégia que faz divisões entre pessoas e grupos, apoiando as características que os desunem e os impedem de constituir um desafio efetivo às relações existentes no exercício do poder. Em contexto de crise política e de batalha acirrada entre partidos políticos, a fragmentação de indivíduo tem sido operacionalizada por meio da estratégia de diferenciação.

A diferenciação como estratégia de fragmentação da ideologia serve para a manutenção de relações de poder. Para que relações legitimadas sejam mantidas e sustentadas em momentos de crise moral, por exemplo, quando são instauradas comissões de inquérito para investigar a ilegalidade de ações praticadas por parlamentares, a diferenciação pode ser estrategicamente operada em formas simbólicas difundidas pela mídia. 
O Governador de Goiás, Marconi Perillo, suspeito de envolvimento com o bicheiro Carlos Cachoeira, por exemplo, tem a identidade fragmentado na representação narrativa publicada na primeira página do jornal Correio Braziliense por meio da estratégia de diferenciação. Contudo, o efeito de sentido provocado pelo modo incorporado à narrativa parece ser minimizado por uso de recurso específico do modo visual, tal como o uso moldura da foto (frame) do parlamentar que o separa de consequências maiores.

Figura 27 - Marconi Perillo na Comissão Nacional de Inquérito Correio Braziliense, 12 de junho de 2012

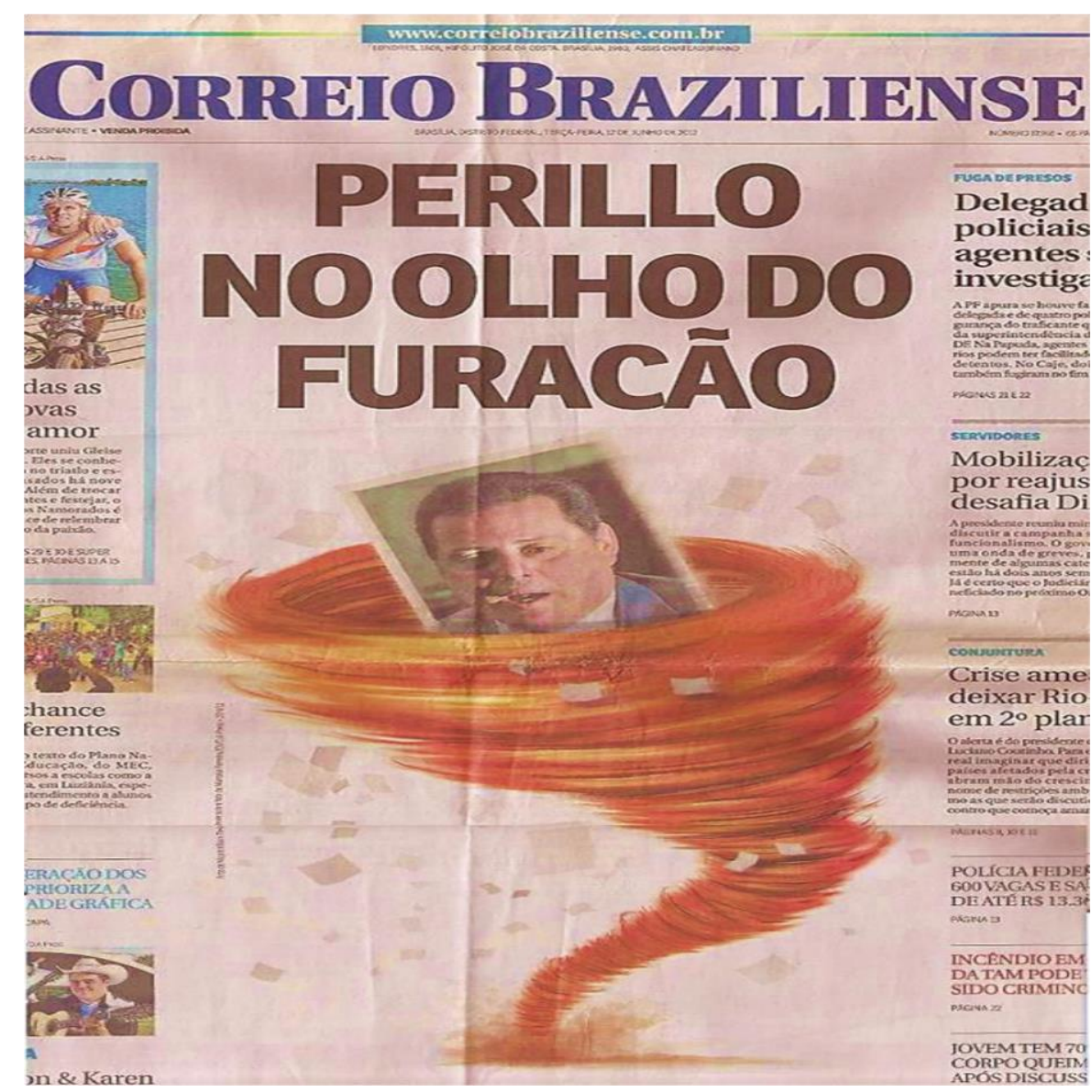

Fonte: Edição n. 17.916, 66 p., p. 1.

Embora o uso da metáfora visual combinada com a expressão PERILLO NO OLHO DO FURAÇÃO fragmentem a identidade do parlamentar, o posicionamento concêntrico do participante representado na composição multimodal e o fato de o fenômeno furação ser passageiro são recursos semióticos que produzem efeito social, mas este efeito é de curto prazo. 
O expurgo é outra estratégia do modo da ideologia que fragmenta da identidade. Bastante usado pelos meios de comunicação impressos, o expurgo envolve a construção de um inimigo relatado como perigoso e contra o qual os indivíduos devem resistir coletivamente ou expurgá-lo, pois é tratado como um desafio ou ameaça. A estratégia de fragmentação por expurgo dirige as forças de oposição potencial a um alvo projetado como mal ou perigoso ou ameaçador. $O$ expurgo de Hakimullah Mehsud, líder do Talibã no Paquistão (o homem que planejou e comandou a execução do ataque contra a CIA, em uma base no Afeganistão em 2009 e que foi morto por operação americana em 2014) é a estratégia operacionalizada no texto multimodal a seguir:

Figura 28 - Hakimullah Mehsud

Newsweek, 18 de novembro de 2013

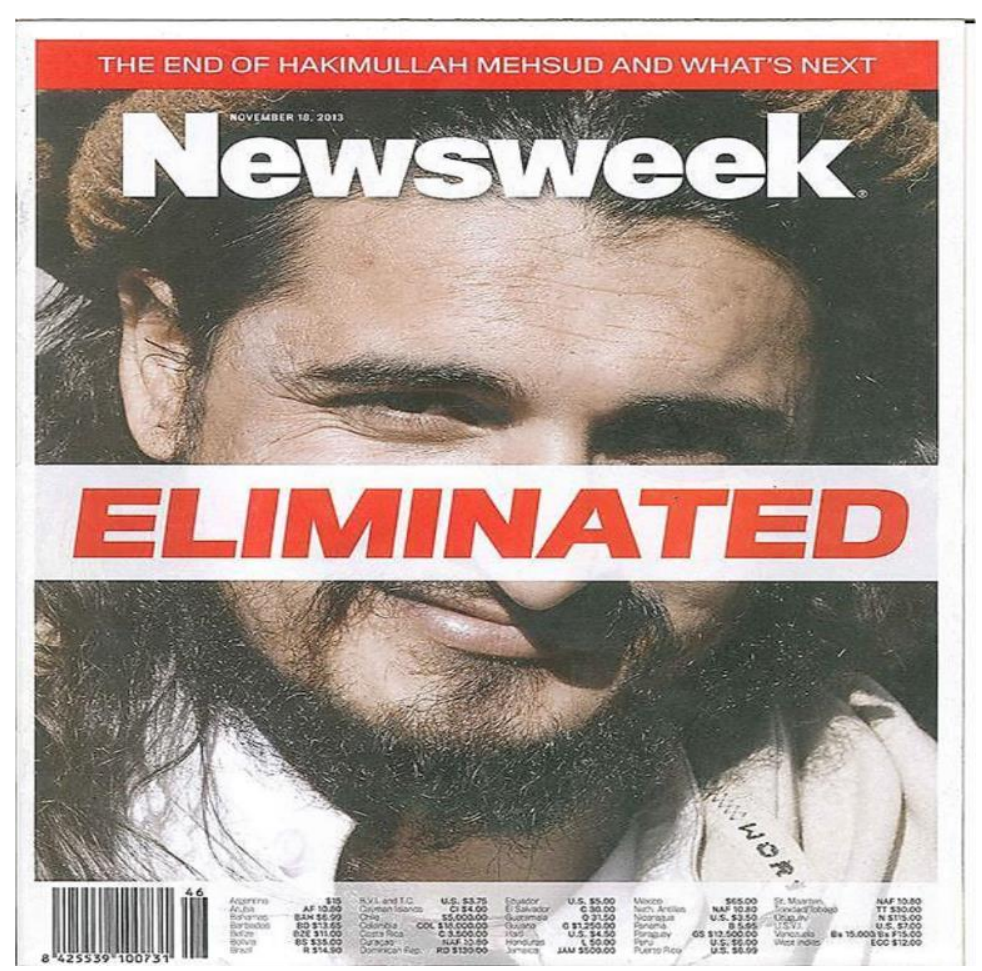

Fonte: Editora Castelo de Pedra Ltda., vol. 1, n. 45.

A fragmentação por expurgo é construída aqui por meio da inserção de faixa horizontal localizada no centro do layout sob o qual imagem do participante representado aparece cortada. Os significados projetados pela metáfora discursiva Eliminated e pelo modo visual complementam-se, evidenciando o sentimento americano de repúdio ao terror. 


\subsubsection{Reificação}

O quinto e último modo de operação da ideologia que, segundo Thompson (2011, p. 88), pode ser analisado nos textos é a reificação. Essa estratégia consiste na retratação de uma situação transitória como se fosse permanente, natural e atemporal, de modo que seu caráter social e histórico é eclipsado. Expressa pelas estratégias de naturalização, de eternização e de recursos sintáticos, como a nominalização e a passivização, a reificação consegue reestabelecer a dimensão de que a sociedade não possui história. A reificação por nominalização ocorre quando ações de participantes são apassivadas e transformadas em nomes quando, por exemplo, se diz "o craque está sendo coroado", ao invés de 'a revista está coroando o craque'. Formas linguísticas específicas, como a anulação do sujeito, a passivização e a nominalização podem ter efeitos negativos sobre a maneira como um fenômeno é compreendido.

Análises de narrativas jornalísticas (VAN DIJK, 2008, p.14) indicam que essas formas tendem a enfatizar as características negativas de determinados grupos étnicos, e que isso é, ainda, mais comum quando um membro do grupo é o agente semântico em um título. Manchetes de jornais e revistas em que haja construções passivas que enfatizam ações negativas de membros já estigmatizados, por exemplo, podem ser realmente tendenciosas, na medida em que diminuem a responsabilidade de grupos minoritários dominantes.

A naturalização, outra estratégia típica de reificação da ideologia, bastante comum nas notícias de jornais, leva os receptores a ver um acontecimento, que é fruto de uma criação social e histórica, como se fosse natural. A eternização, por sua vez, é mais uma estratégica de reificação que esvazia o caráter dos fenômenos sócio-históricos - costumes, tradições e instituições - para tratá-los como se permanentes, imutáveis e recorrentes, de maneira que os traços de sua origem, uma vez perdidos, tornam-se inimagináveis.

A narrativa, a seguir, é um exemplo de reificação por eternização que visa ao reestabelecimento de relações de poder, em momento de crise econômica e política, posto que, no coração da sociedade, brasileira se encontra o futebol. 
Figura 29 - Jogador Neymar

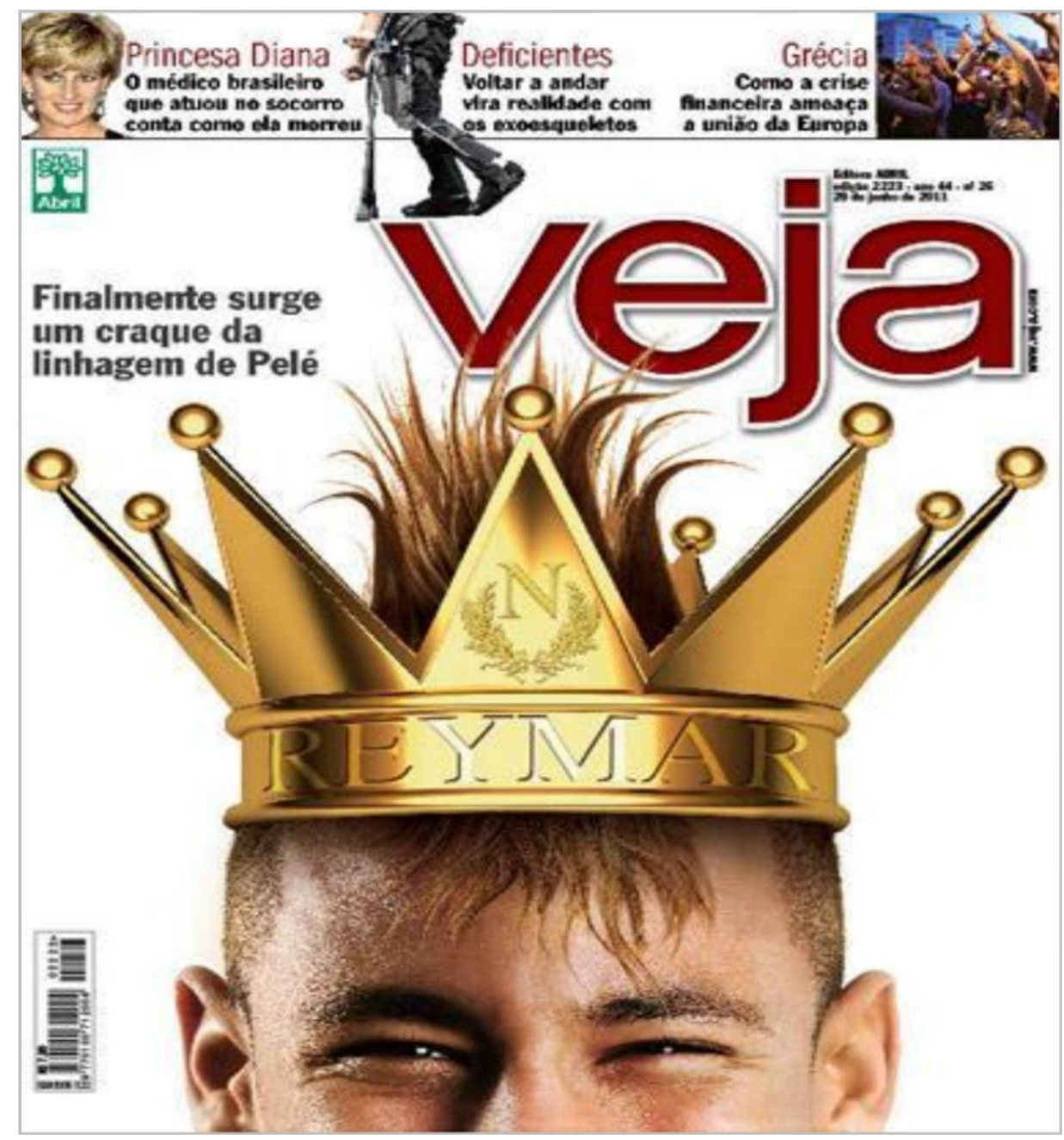

Fonte: Edição 2.223, ano 44, n. 26.

As habilidades do jogador de futebol, Neymar, outrora reconhecidas também em outros jogadores de sucesso no futebol brasileiro (Zico, Sócrates, Ronaldo e Ronaldinho), são representadas pela coroa, símbolo da nobreza - algo visto como permanente e imutável. A reificação do futebol brasileiro é uma eficaz operação da ideologia que mantém autoestima dos brasileiros que se identificam por meio do futebol e fortalece relações políticas e econômicas.

Do exposto sobre as estratégias da ideologia, entendemos que a ideologia pode ser uma questão mais saliente para tipos de discurso da mídia, do que para outros; que textos contraditórios em suas formas e significados, de fato, funcionam ideologicamente no controle social, na reprodução social e como artefatos culturais no mercado competitivo. 
Ainda que as narrativas da mídia impressa contemporânea mantenham as pessoas informadas em seu próprio direito, elas contribuem para mudanças sociais aceleradas e, portanto, para transformações culturais e identitárias. Assim, reiteramos a importância da identificação, do discernimento pelo exame atento dos vários modos de operação da ideologia nas formas da mídia que detêm maior confiabilidade do público leitor, porque elas, de fato, projetam ideologias globais, ideologias dos meios que as difundem, ideologias das instituições de onde elas saem e as ideologias das classes para as quais elas são destinadas. Nas capas dos impressos em que as representações aparecem mais elaboradas, as ideologias geralmente estão mais implícitas que explícitas, porque assim produzem mais efeitos subliminares para a dinâmica de articulação dos grupos legitimados e, portanto, à manutenção do senso comum.

\subsection{Narrativas argumentativas midiáticas e seus efeitos sociais}

O discurso da mídia, como sabemos, é local de processos complexos, contraditórios que podem ou não incluir processos ideológicos. Em parte as formas discursivas da mídia têm contribuído positivamente para mudanças e transformações do nosso tempo. Entretanto, comunidades e indivíduos têm sido afetados em seu senso de lugar - muitos ficaram confusos e perderam valores importantes. Se benéficas ou prejudiciais, o fato é que mudanças globais aceleradas têm afetado bastante o estilo de vida das pessoas.

Para Ulrich Beck (1997, p.12), as mudanças globais devem-se a várias razões: vivemos um tempo em que o controle das decisões civilizacionais não é mais possível, em uma época em que os problemas políticos e econômicos internacionais são crescentes, em uma era em que o progresso pode se transformar em autodestruição e na destruição dos outros. Isso nos leva a refletir criticamente sobre os gêneros da mídia que cotidianamente retratam as situações e os eventos sociais e sobre as mudanças na ordem do discurso.

Fairclough e Fairclough (2012, p.3) asseguram que o discurso é de fundamental importância no desenvolvimento de estratégias agentivas para a prossecução de políticas principalmente em tempos de crise. Nesses contextos, as pessoas têm que tomar decisões sobre como agir em resposta aos problemas 
decorrentes de desequilíbrios muitas vezes inevitáveis. $\mathrm{O}$ aspecto subjetivo nas narrativas, por conseguinte, é vital para tomadas de decisão. Para ter efeitos de modelagem das ações, principalmente, quando as pessoas são representadas de modo persuasivo e convincente (FAIRCLOUGH e FAIRCLOUGH, 2012, p. 3). Isso implica ver as narrativas como representações compostas de argumentos com significados que incentivam e influenciam processos de tomada de decisões, ou seja, como premissas com argumentos voltados para a obtenção de resultados políticos específicos.

Para Fairclough e Fairclough (2012, p. 4), a argumentação prática é importante porque tem a capacidade de diminuir o impacto da racionalidade limitada. Caracterizada por suas estratégias de meios e de fins, por julgamentos sobre o que deve ser feito e pela adição de circunstâncias que se tornam contextos de ação, a argumentação prática não força as ações, mas as influencia. Em narrativas políticas sobre a crise, por exemplo, há circunstâncias incorporadas em premissas de meta que representam o contexto de ação e funcionam como estados de coisas desejáveis.

As narrativas políticas multimodais são organizadas, de certa maneira, para que as decisões e as ações levem aos resultados previstos. No entanto, quando globais, elas podem influenciar de forma generalizada as decisões e as ações com efeitos sobre os rumos das mudanças econômicas e sociais. As narrativas na realidade são úteis à prevalecência de estratégias e de políticas sobre outras linhas de interesse político. Os meios de comunicação de massa cumprem, por conseguinte, relevante papel em questões externas à experiência pessoal imediata.

Embora ainda haja dificuldade para prever os efeitos das semioses sobre a opinião pública, as teorias da comunicação já reconhecem que processos de mídia podem ter fortes efeitos sobre a vida em sociedade. Macquail (2013) assegura que as narrativas jornalísticas contribuem bastante para as instituições públicas e privadas, para os negócios e para a confiança do consumidor. $O$ uso de figuras públicas pela mídia, por exemplo, pode ser muito eficiente na formação de um ponto de vista particular.

É como explica Macquail (2013, p. 428): 
Vivemos em um mundo saturado por sons e imagens de mídia, onde o governo, a política e a as empresas operam com base na suposição de que sabemos o que está acontecendo no resto do mundo. Poucos de nós não conseguiriam pensar em algum exemplo pessoal em que obtivemos informações importantes ou formamos opinião em função da mídia. Muito dinheiro e esforço também são gastos para direcionar a mídia a atingir esses efeitos (...) e é difícil acreditar que isso aconteceria sem uma convicção de que funciona mais ou menos conforme o planejado. Certamente, os próprios meios de comunicação parecem confiantes em sua capacidade de alcançar os efeitos pretendidos.

A consciência da mídia quanto aos efeitos dos eventos que ela representa é incontestável, tanto que, eventualmente, os registra. Assunto coberto pela mídia global (o conflito entre os Estados Unidos e o Mundo Árabe, a denominada Guerra ao Terror), e atualizado pelo Correio Braziliense, exemplifica a consciência da mídia acerca dos efeitos que as suas formas produzem.

Figura 30 - Guerra ao Terror

Correio Braziliense, de 20 de janeiro de 2013

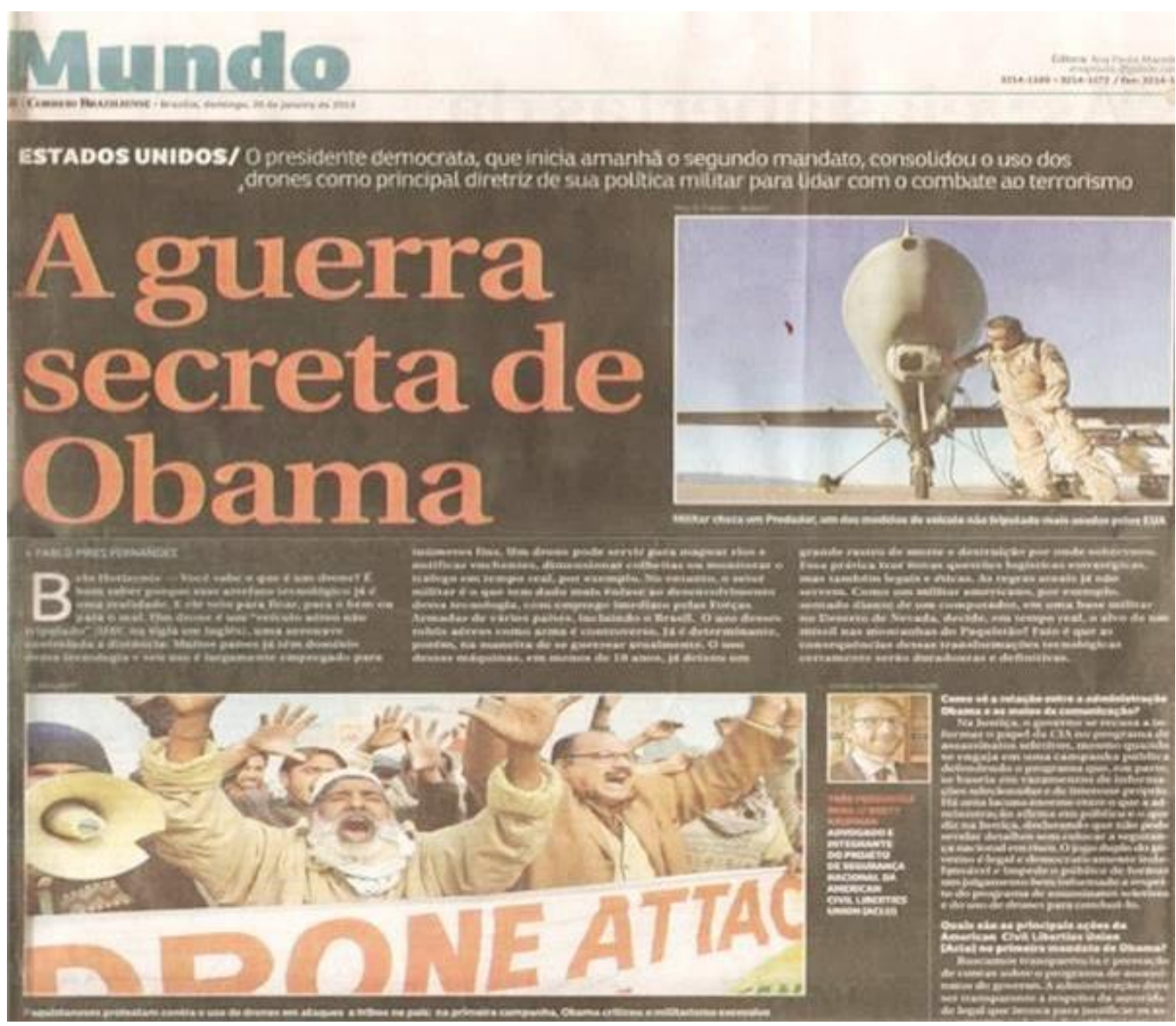

Fonte: Jornal Correio Braziliense, Coluna Mundo, p. 12. 
A narrativa sobre conflito internacional é impactante. Trata da possibilidade do uso de avião americano (o drone) controlado a distância com poder de destruição contra adversários de guerra. $\mathrm{O}$ uso do drone como solução do coflito produz o impacto cuja fonte essencial está na magnitude do perigo. Expressões de pavor dos adversários árabes em face da ameaça são captadas pela câmara fotográfica e mostradas ao público leitor. A política americana contra o terror tem sido amplamente apoiada no ocidente, mas os significados evocados pelo texto contrariam o senso, devido ao sentimento de preservação da vida. Os efeitos de sentido produzidos pela foto da realidade captada têm efeitos subjetivos de longo prazo sobre a cognição social porque ameaçam a vida humana.

Muitos dos efeitos dos textos não são fáceis de mensurar, pois, além de complexos e sutis, são difíceis de serem analisados pelas formas de avaliação disponíveis. Sendo assim, é necessário cautela para que mensagens específicas não sejam confundidas com outras mensagens, e para que determinados efeitos não sejam tomados como situações reais, mesmo porque a maior parte do é refletido pela mídia provêm da sociedade e vice versa.

De acordo com Macquail (2013, p.137-147), as narrativas midiáticas distinguem-se em termos de intencionalidade e de não intencionalidade e em termos de curto e de longo prazos. As narrativas planejadas para ter efeitos de curto prazo são os vieses voluntários, e as não planejadas, mas que têm efeito são os vieses involuntários. Efeitos intencionais de longo prazo são produzidos por políticas e os efeitos involuntários são ideológicos.

Quadro 5 - Efeitos sociais das Narrativas

\begin{tabular}{|l|l|l|}
\hline \multicolumn{1}{|c|}{} & CURTO Prazo & LONGO PRAZO \\
\hline Planejadas & Vieses voluntários & Políticas \\
\hline Não Planejadas & Vieses involuntários & Ideológicas \\
\hline
\end{tabular}

Fonte: Elaborado pela autora com base em McQuail (2013). 
Isso aponta para o fato de que as narrativas políticas são organizadas para ter efeitos sociais e que as narrativas ideológicas também produzem efeitos sobre a cognição coletiva e individual, sejam estes efeitos planejados, sejam não planejados. Acreditamos, pois, que as mudanças no padrão geral de valores sociais, assim como na identidade cultural de um povo são, em parte, promovidas pelos modos de construção dos sentidos difundidos cotidianamente, por narrativas políticas ideológicas da mídia contemporânea.

Macquail (2013) ressalta que os vieses contextualizados por figuras públicas têm efeitos planejados de curto prazo sobre a opinião pública e que os vieses que focalizam algum abuso ou perigo, embora não sejam planejados para ter efeitos, podem causar reações individuais e coletivas. As narrativas políticas que difundem conhecimentos para fins de desenvolvimento tecnológico são planejadas para ter efeitos de longo prazo sobre a cognição humana.

Para Thompson (2011, p.96) os modos da ideologia incorporados nas formas simbólicas, em circunstâncias particulares, podem servir para estabelecer relações de poder das quais alguns indivíduos e grupos se beneficiam e outros não. Nesse sentido, Fairclough (2003, p. 8) ressalta que os efeitos sociais dos textos dependem, sobretudo, dos modos como os eventos sociais são narrados e da sua intensidade de mediação pelos meios de comunicação de massa. As formas simbólicas ideológicas, segundo a perspectiva social crítica da ideologia, são produtos negativos porque favorecem as relações de poder e de dominação.

A narrativa jornalística política, adiante, foi divulgada na primeira página do Correio Braziliense durante as manifestações populares contra a inflação e a corrupção, quando a mídia gerenciava os protestos que haviam alterado as relações de poder e que atraiam a opinião pública. O texto narra a prisão imediata de um parlamentar, condenado a 13 anos por corrupção, em um ponto de ônibus na L2 Sul, às onze horas do dia 28 de junho - dia anterior à publicação deste texto: 
Figura 31 - Detenção de membro parlamentar

Correio Braziliense, 29/06/ 2012

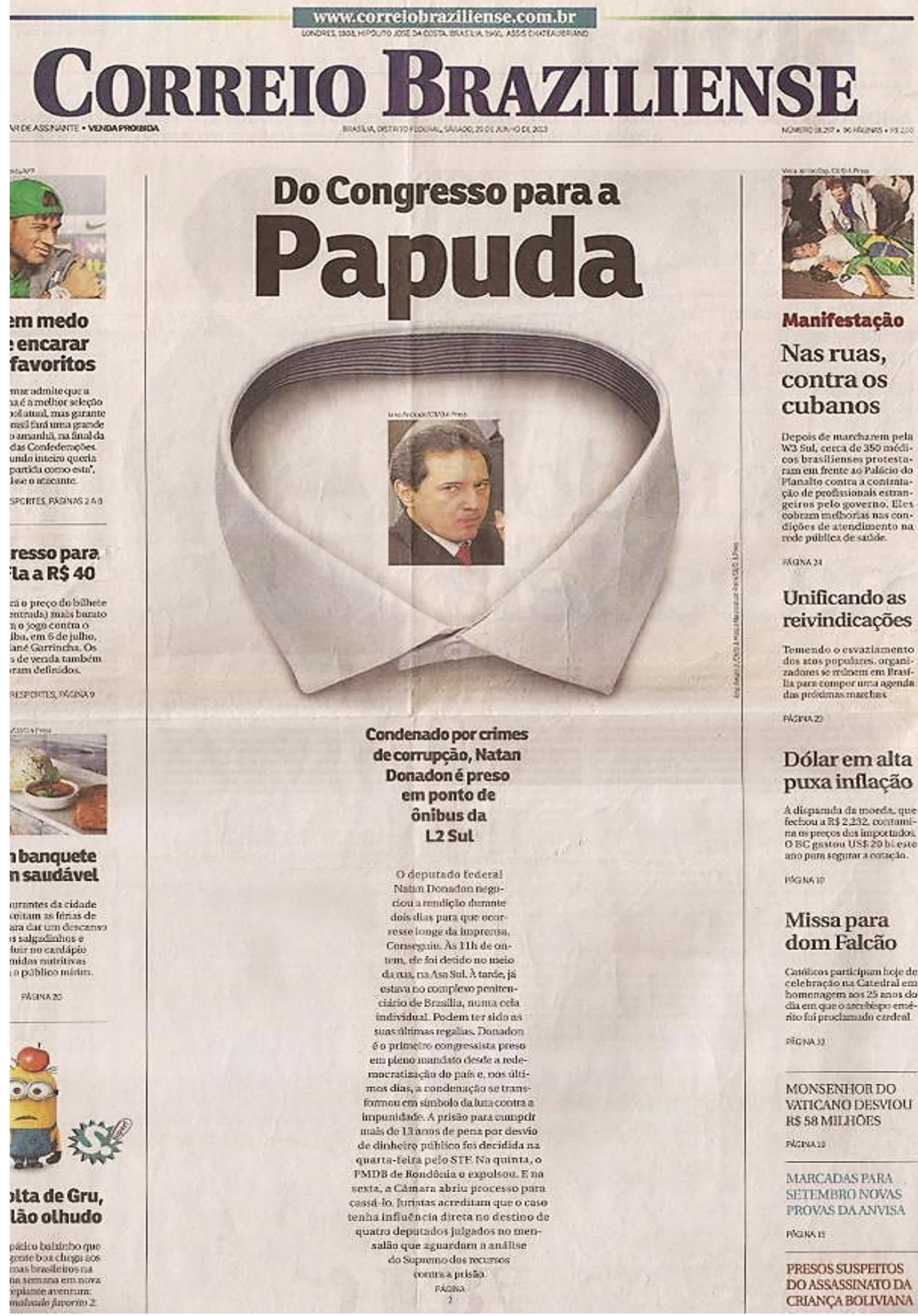

Fonte: Correio Braziliense, n. 18.297, 96 p., p. 1. 
A manchete Do Congresso para a PAPUDA (penitenciária de Brasília) remete a um crime do colarinho branco ${ }^{23}$ (metáfora de corrupção) praticado por um parlamentar como forma de simbolizar a luta contra a impunidade no Brasil. A estratégia de fragmentação por expurgo vai ao encontro das reivindicações populares e funciona como forma de controle do movimento. Isso mostra que as narrativas multimodais da mídia seguramente não são reproduções neutras dos fatos e acontecimentos da realidade. A projeção de ideologias globais, das instituições de onde elas saem e das classes para as quais são destinadas é conscientemente planejada. Nos suportes onde essas formas simbólicas aparecem com maior visibilidade, as ideologias são menos explícitas porque, dessa forma, modelam melhor as condutas para a manutenção do status quo.

Enfocamos os contextos sócio-históricos das práticas sociodiscursivas da mídia impressa desenvolvidos no decorrer dos tempos, bem como os contextos institucionais, em especial, as revistas nacionais e internacionais de alto consumo. Salientamos alguns dos modos estratégicos da ideologia operacionalizados em representações narrativas multimodais publicadas por essas revistas, com o intuito de facilitar a compreensão da análise crítica semiótica realizada no quinto capítulo do estudo. Finalmente, foram elucidados os efeitos sociais das narrativas políticas e ideológicas sobre a vida em sociedade. Com o objetivo de responder às arguições formuladas, o próximo capítulo discute as bases teóricas que fundamentam o estudo.

${ }^{23}$ Crime cometido por pessoa respeitável e de alta posição social, no exercício de suas ocupações. Representações dos crimes de colarinho branco na mídia se sobrepõem aos crimes corporativos, porque são cometidos por indivíduos e funcionários públicos, os quais geralmente estão engravatados. 


\section{CAPÍtULO 3}

\section{FUNDAMENTOS TEÓRICOS MULTIDISCIPLINARES}

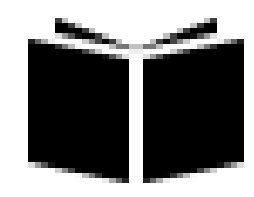

Com base na orientação definida pelo triângulo discurso - cognição sociedade, a pesquisa intitulada Narrativas Midiáticas Multimodais e seus Efeitos Sociais encontra as bases de sua fundamentação na Teoria Semiótica Social da Multimodalidade, campo da linguagem que descreve e interpreta os significados dos modos semióticos que integram os textos contemporâneos; na Análise de Discurso Crítica, teoria social da linguagem que dialoga com outras ciências para analisar, com criticidade, entre outras coisas, o discurso ideológico da mídia global; e na Teoria Sociocognitiva do Contexto, abordagem desenvolvida no âmbito dos estudos do discurso que investiga a interface cognitivista existente entre os contextos e os discurso em uso nas sociedades da pós-modernidade. O capítulo também explana sobre as categorias de análise selecionadas para a aplicação aos dados.

\subsection{Teoria Semiótica Social da Multimodalidade}

A Teoria Semiótica Social da Multimodalidade (TSSM) é um campo de trabalho e um domínio do conhecimento que vê a linguagem como parte de um conjunto multimodal ao qual a representação e a comunicação recorrem para realizar diferentes trabalhos comunicativos. A teoria constitui-se com base nos seguintes pressupostos: os contextos sócio-históricos e institucionais moldam os modos semióticos (a fala, a escrita, o gesto, a imagem, o som, a música, a arte, o movimento etc.) usados na comunicação humana; os significados elaborados por 
recursos semióticos ${ }^{24}$ dos modos - ações materiais e artefatos produzidos psicologicamente, ou tecnicamente, ou juntos, mas de modo organizado e usados com propósitos comunicativos - são influenciados por motivações e interesses particulares e delineados por normas e por regras aplicadas no momento da produção; os recursos apropriados dos modos semióticos representam as experiências e os objetos do mundo social, mas eles podem combinar-se e complementar-se com outros modos semióticos para produzir e para reproduzir significados comunicativos (JEWITT, 2011).

A TSSM reconhece que os aspectos do mundo social, requisitos fundamentais do mundo semiótico, do mundo do significado, da ética e dos valores, são formados pela instabilidade e pela provisoriedade. Assim, todo evento de comunicação é, em princípio, imprevisível em sua forma, estrutura e desdobramento (KRESS, 2010, p. 26). Nessa perspectiva, os discursos são conhecimentos sobre aspectos da realidade construídos socialmente de maneira adequada aos interesses dos atores sociais. Discursos sobre conflitos étnicos, por exemplo, envolvem tanto uma determinada versão do que acontece, de quem está envolvido, do que é feito, de quando e onde é feito, quanto um conjunto de interpretações, de argumentos e de avaliações em relação ao conflito ou sobre seus aspectos. Discursos midiáticos sobre conflitos de guerra servem aos interesses dos países em que os jornais são produzidos e na forma como costumam ser percebidos pelo público. Dessa forma, eles não mencionam a influência da colonização, nem da descolonização sobre os conflitos representados, no entanto defendem a não intervenção, com base na construção de conflitos ocorridos no passado.

Em discursos da mídia contemporânea, a economia aparece como categoria explicativa. Neles, a inclusão e a exclusão de participantes e de eventos servem para ligar as versões do que se passa com outras interpretações, julgamentos, argumentos etc. Alguns discursos incluem uma grande ênfase sobre os acontecimentos reais e fornecem poucos argumentos e interpretações, outros formam argumentos abstratos, contentando-se com uma versão ampla e geral do que as partes em conflito realmente fazem (KRESS E VAN LEEUWEN, 2001, p. 5).

\footnotetext{
${ }^{24}$ Os recursos semióticos são uma poderosa estratégia para capacitar as pessoas a ver como a realidade é representada, oferecendo o potencial para imaginá-la diferentemente e para redesenhá-la (JEWITT, 2011, p.22).
} 
Os discursos podem expressar o senso comum, ser inovadores, e talvez até mesmo subversivos, porque são relativamente independentes dos gêneros e dos modos. Os discursos texturizados por meio dos modos semióticos seguramente desenvolveram significados por meio de processos que alcançaram os recursos apropriados para fazer significar visualmente as experiências do mundo. Cada modo semiótico tem seu próprio meio particular de representar e de perceber conhecimentos, crenças, atitudes semelhantes e de combinar as modalidades da linguagem de diversas formas. Assim como a oralidade e a escrita, as linguagens não verbais representam pessoas, lugares, coisas, produzindo e reproduzindo significados de modo a satisfazer os interesses das instituições dentro das quais elas são produzidas (KRESS e VAN LEEWEN, 1996, 2006).

Entendemos que a produção das formas e dos produtos semióticos de eventos sociais envolve o uso de recursos de todos os modos da linguagem, quais sejam: combinações de discursos, encaixamento de discursos em interações particulares, combinação dos modos semióticos etc. Assim como a escrita, percebida como gravura em pedra, como a caligrafia sobre certificados, como a impressão em papel brilhante, os outros modos semióticos também podem adicionar simultâneas realizações de discursos e de tipos de interação para compor significados. O design ${ }^{25}$, realização de discursos no contexto de uma situação de comunicação com acréscimo de algo novo, por exemplo, mesmo separado da produção de um produto semiótico, requer diferentes materialidades para realizarse.

Todo um conjunto de habilidades é requerido em uma produção da mídia - a produção refere-se à organização da expressão para a articulação do material do evento semiótico ou ao material de produção do artefato semiótico. Todo um conjunto de habilidades é requerido em uma produção da mídia: habilidades técnicas, habilidades da mão e do olho e habilidades dos modos semióticos de mídia. No que diz respeito à distribuição dos produtos da mídia, destaca-se a tendência de esta não ser vista como semiótica, como algo que lhe acrescenta qualquer significado, mas sim como o que facilita as funções pragmáticas de conservação do material. Com o tempo, porém, a distribuição dos bens informativos

\footnotetext{
${ }^{25} \mathrm{O}$ design constrói conhecimento e interação porque converte situações de comunicação em mudanças (KRESS e VAN LEEUWEN, 2001).
} 
multimodais transforma, em parte ou no todo, em meio apropriado de produção (KRESS e VAN LEEUWEN, 2001).

\subsubsection{A narrativização visual}

De acordo com Kress e van Leeuwen (1996, 2006), a narrativização é um dos processos discursivos que pode ocorrer também em imagens. Em imagens, os sistemas semióticos representativos da cultura, tais como eventos, ações, relações, pensamentos e objetos do mundo dinâmico, são bastante usados. Os recursos semióticos mais usados na narrativização dos eventos são os ângulos. A natureza exata da relação de potência e de envolvimento não é dada, mas pontos de vista podem ser representados por ângulos.

Os ângulos elevados e frontais são orientados para a ação, transmitem poder e envolvimento com os participantes representados e podem ser lidos como pontos de vista em imagens subjetivas. O imaginário do espectador, por exemplo, pode ser introduzido no primeiro plano de uma imagem, em maior ou menor grau, por meio da inclusão de algo ou de alguém para criar um ponto de vista. Ângulos de cima para baixo transmitem potência máxima, contemplam o mundo com base no conhecimento científico e são orientados para o conhecimento teórico. A focalização de algo ou de alguém, por meio de ângulos, narrativiza um ponto de vista que pode estar relacionado a uma situação concreta e impõe um espectador fictício entre os participantes representados e os participantes interativos. Uma das fontes de poder dos ângulos, portanto, se deve ao fato de que eles podem ser lidos (KRESS e VAN LEEUWEN (1996 2006). 


\section{SIGNIFICADOS DOS ÂNGULOS EM IMAGENS}

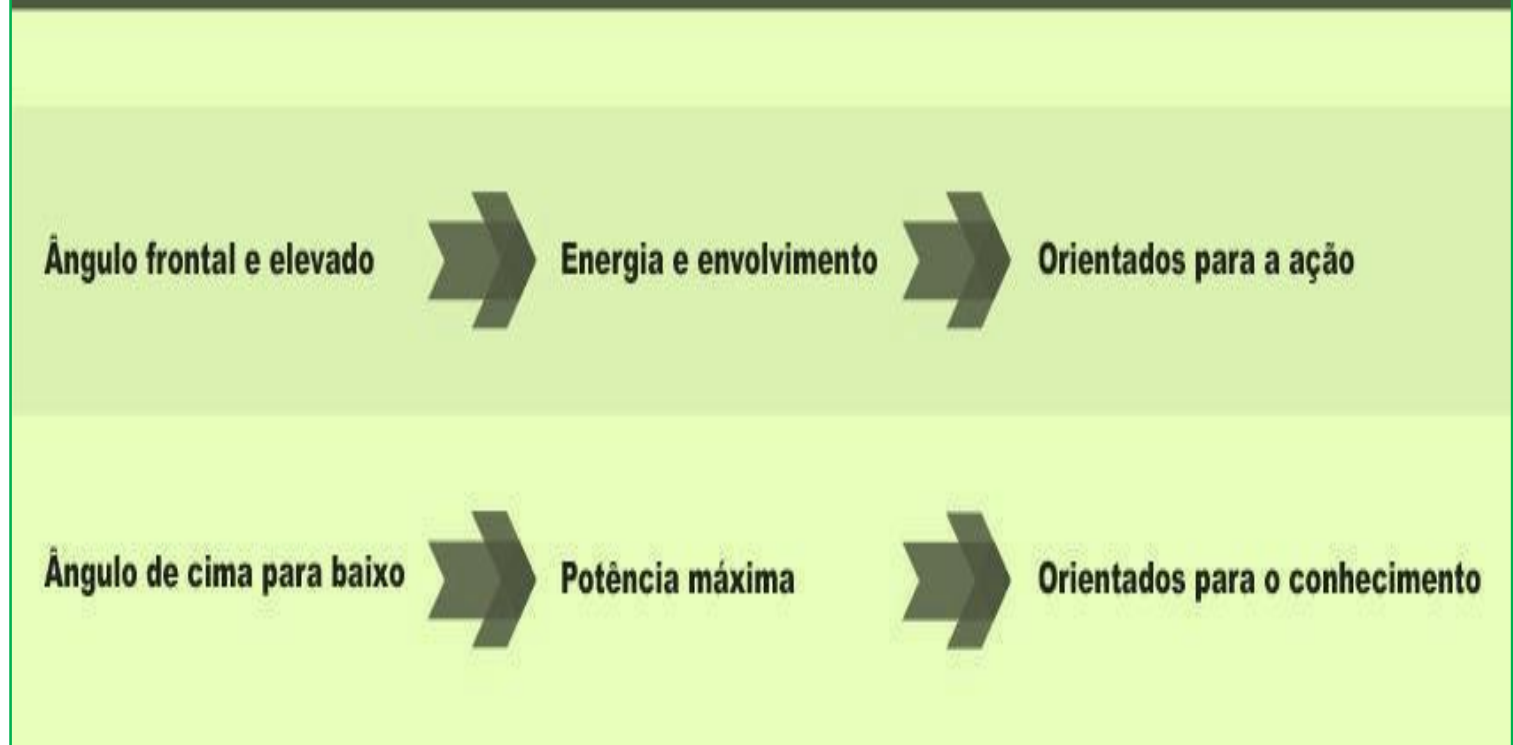

Fonte: Elaborado pela autora com base em Kress e van Leeuwen (2006).

Em imagens objetivas, os diagramas, os mapas e os gráficos geralmente codificam uma atitude objetiva realizada por forma diretamente frontal, indicativa de envolvimento máximo, ou por forma perpendicular de cima para baixo, indicativa de potência máxima. Tais formas sugerem posições de espectadores capazes de neutralizar as distorções que normalmente vêm com a perspectiva. Pontos de vista objetivos são configurados pelo ângulo transversal e pela visão de raios $X$ que sondam, além da aparência e da superfície, os níveis mais profundos e ocultos. Estes elementos podem ser adicionados aos gráficos e às seções transversais, para dar um sentido da realidade e da existência física.

O mundo tridimensional, antes captado a partir do concreto, foi restaurado com novos tipos de pessoas, de coisas e de lugares. Nas narrativas midiáticas multimodais, formas em que um senso maior da realidade é dado, o ângulo e a postura alta são ferramentas de produção visual do conhecimento e símbolos do poder informacional. 


\section{Quadro 7 - Narrativização em imagens objetivas}

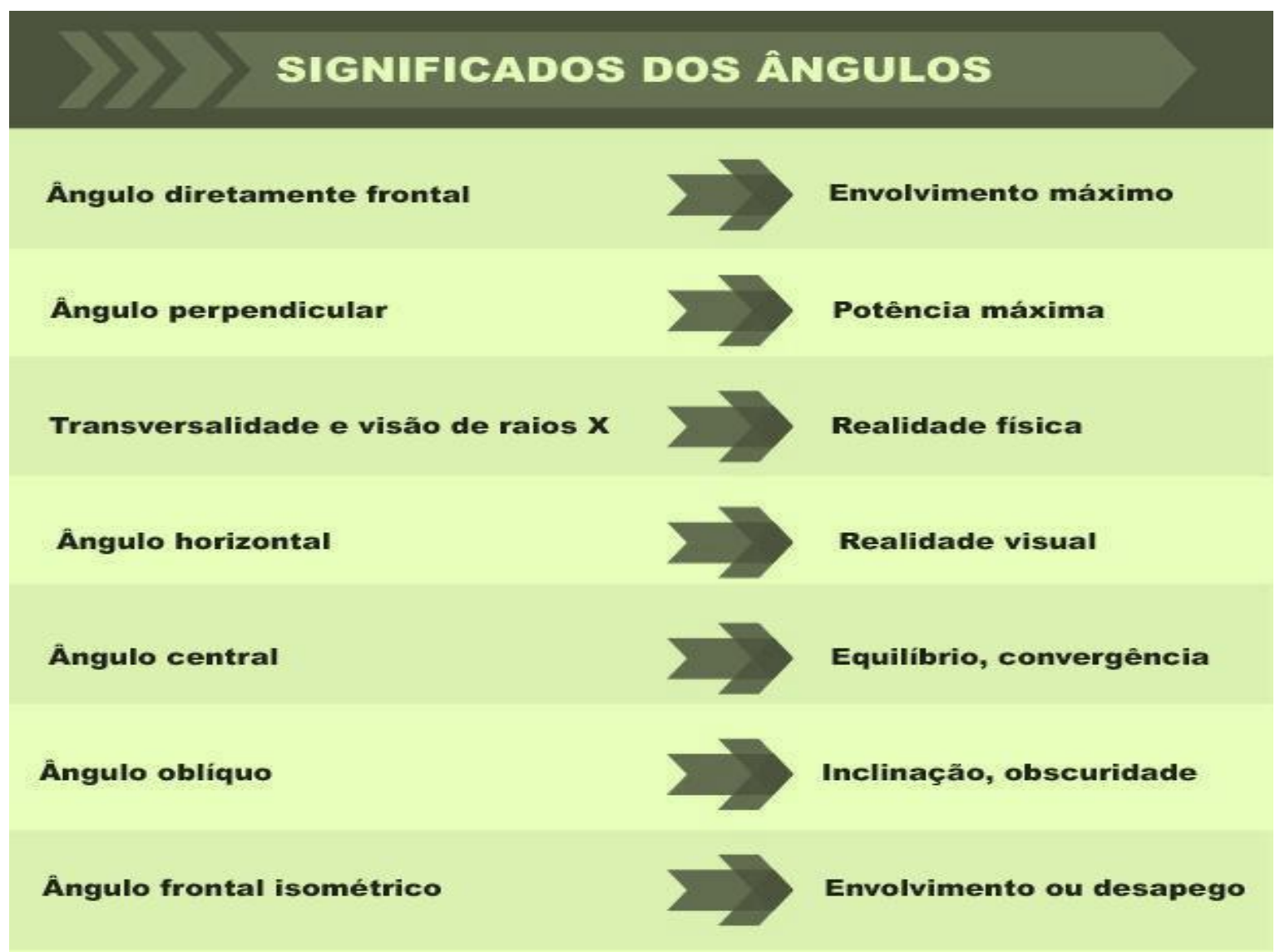

Fonte: Elaborado pela autora com base em Kress e van Leeuwen (2006).

O ângulo horizontal, um processo objetivo que acontece, principalmente, nos contextos em que a forma popularizada é comemorada e veiculada aparece em imagens esquemáticas vestidas com roupas da realidade visual. $\mathrm{Na}$ perspectiva central, os elementos representados são vistos de frente e na altura dos olhos elementos laterais superiores e inferiores são escondidos. Se há vista a partir de um ângulo oblíquo, um dos lados será visível e o outro não. Se o ângulo alto para baixo for alto, o topo é exibido. A perspectiva frontal-isométrica baseia-se nas dimensões objetivas dos participantes representados. Ela não é usada nos desenhos técnicos, em que as dimensões dos objetos são medidas. Na perspectiva frontal-isométrica, não há uma escolha entre o envolvimento e o desapego. É a analogia em termos visuais da "impessoalidade" da linguagem científica. A frente é distorcida, o objeto não é representado como um quadrado e os paralelos horizontais e verticais não convergem. O ponto de vista individual estende o espaço indefinidamente como um ângulo relativamente alto (KRESS e VAN LEEUWEN, 1996, 2006). 
Em vista do exposto, consideramos que processos da narrativização materializados pelo uso de ângulos diversos, desenvolvidos ao longo dos tempos nas culturas, são utilizados em narrativas midiáticas multimodais para focalizar pontos de vista particulares.

\subsubsection{A composição de significados}

Aspecto importante em toda análise multimodal é a composição de significados. A composição é a forma pela qual os elementos representados e interativos são estabelecidos para se relacionar uns com os outros em um todo significativo. Conforme van Leeuwen (2005), o processo de composição de significados baseia-se no senso de equilíbrio, por ser este o que forma a matriz essencial para a produção e a recepção de mensagens espacialmente articuladas. A colocação de algo no centro, do lado direito ou à esquerda de uma imagem é um processo semiótico em cuja função o equilíbrio pode ser mostrado apontando para aquilo que o torna visível.

Vale destacar o que Kress e van Leeuwen $(1996,2005)$ dizem acerca da composição de um texto multimodal. Conforme os autores, há três princípios relacionados na composição de significados: a saliência, o valor da informação e o enquadramento das informações. A saliência, princípio composicional que atrai a atenção do espectador da imagem, envolve os diferentes graus de localização dos planos (primeiro, médio e fundo), o tamanho relativo dos elementos na composição, as cores e os tons contrastantes com os valores informacionais, a nitidez da imagem etc. O valor da informação envolve a localização (à esquerda, ao centro, à direita), a posição (acima, abaixo e os planos horizontal e vertical) e a proporção dos elementos participantes da composição. $O$ enquadramento diz respeito à presença ou à ausência de elementos: posicionamentos, linhas de conexão ou de desconexão dos elementos de uma imagem significando ou não relacionamento.

Os significados contidos na distinção entre a esquerda e a direita têm sido uma importante fonte de significado em diferentes culturas e ao longo da história. A esquerda é geralmente associada ao dado (informação antiga) e negativo e a direita à informação nova e a valores morais positivos. A dimensão horizontal é usada para 
separar o lado esquerdo e para indicar o domínio daquilo que já foi formulado e especificado para os usuários. Quando usada para o lado direito, para o domínio do novo, a dimensão horizontal significa mudança e inovação. Da mesma forma, o antes e o depois correspondem à esquerda e à direita e não só na escrita, mas em todos os modos espaciais semióticos.

A parte superior do espaço semiótico, por exemplo, tem o poder de vender a informação, o que é ideal, e a parte inferior o poder de informar sobre o modo de entretenimento. $\mathrm{O}$ espaço superior também pode significar afetos positivos e poder, mas excessos de abstração significam idealismo. Por sua vez, o espaço inferior pode representar uma atitude realista, mas também a falta de energia pode indicar um efeito negativo. A parte superior de uma página de jornal geralmente tem uma clara estrutura do dado e do novo. À esquerda geralmente são dispostas as palavras, e à direita as fotos salientes (de uma celebridade, por exemplo).

Quando uma composição polariza os espaços superior e inferior na composição semiótica, colocando elementos contrastantes nas seções superior e inferior do espaço semiótico, os elementos colocados na parte superior são apresentados como o ideal e aqueles colocados na parte inferior como o real. Em contraste com a esquerda e a direita, o que está acima e abaixo é diferente da nossa experiência cotidiana. Mas, como em nosso meio há sempre o abismo entre o céu (eterno e imutável) e a terra (em constante mudança), o alto pode tornar-se demasiado elevado, abstrato e etéreo a ponto de ser associado ao irreal, e o baixo tornar-se positivo e realista (VAN LEEUWEN 2005, p. 204).

O plano horizontal pode ser movido em todas as direções com igual facilidade para marcar atividades. Já o plano vertical não, por ser este o plano do espetáculo. A gravidade entra em jogo porque o movimento requer esforço. Nesse sentido, é interessante destacar que as metáforas da verticalidade são as que desempenham papel significativo na interpretação e na manutenção do poder e da diferença social.

Kress e Van Leeuwen (2006, p. 194) ainda ressaltam que elementos informacionais de valor, como o centro e as margens, nem sempre envolvem divisão e polarização, pois, embora o espaço central seja mais importante, mais sagrado, 
mais público e integrador das atividades, ele não se opõe às margens. Ele une o que é organizado em torno dele, criando uma relação de igualdade entre os elementos em um determinado círculo concêntrico. Sempre que as pessoas e os objetos estão dispostos no espaço, há a escolha da polarização ou da centralização. Às vezes, ambos podem existir ao mesmo tempo. Este princípio pode ser aplicado à forma como os elementos são organizadoss, por exemplo, em uma capa revista.

Reconhecemos que é difícil analisar o significado do modelo centro-margem porque o seu uso se estende a diferentes modos semióticos, em contextos específicos. O centro é apresentado como o núcleo do que é comunicado e as margens são apresentadas como sentidos subservientes, auxiliares ou dependentes dele. Como a centralidade não admite grau, os graus de marginalidade dependem da saliência do centro e da sua distância a partir do centro. Mesmo quando o centro está vazio, essa centralidade vai continuar a existir à revelia, como o pivô invisível em torno do qual tudo gira. Em muitos casos, as margens são semelhantes, de modo que não há sentido de polarização sem o senso de divisão entre o dado e o novo, ou ideal e real. No entanto, também acontece a combinação do centro e da margem com o dado e o novo e com o ideal e o real, mas o modo triádico é o mais comum de combinação com o centro e a margem.

Em termos de perspectiva, os objetos colocados em primeiro plano de uma imagem são mais salientes do que os objetos de fundo, os elementos que se sobrepõem a outros elementos são mais salientes - fatores culturais específicos podem ser substituídos pela saliência perceptual de outros elementos. Em composições simétricas, à esquerda e a direita são equilibradas, mas o equilíbrio torna-se mais agitado quando um lado é visualmente mais pesado que o outro, pois o balanceamento do foco é deslocado para fora do centro geométrico do espaço. $O$ alcance e a manutenção do equilíbrio em situações de desbalanceamento são uma experiência básica que resulta de um senso de equilíbrio em todas as atividades humanas, incluindo as atividades semióticas (VAN LEEUWEN, 2005). O quadro adiante mostra os recursos semióticos usados em uma composição multimodal para representar ações, eventos, objetos e experiências. 
Quadro 8 - Princípios da composição de significados em imagens

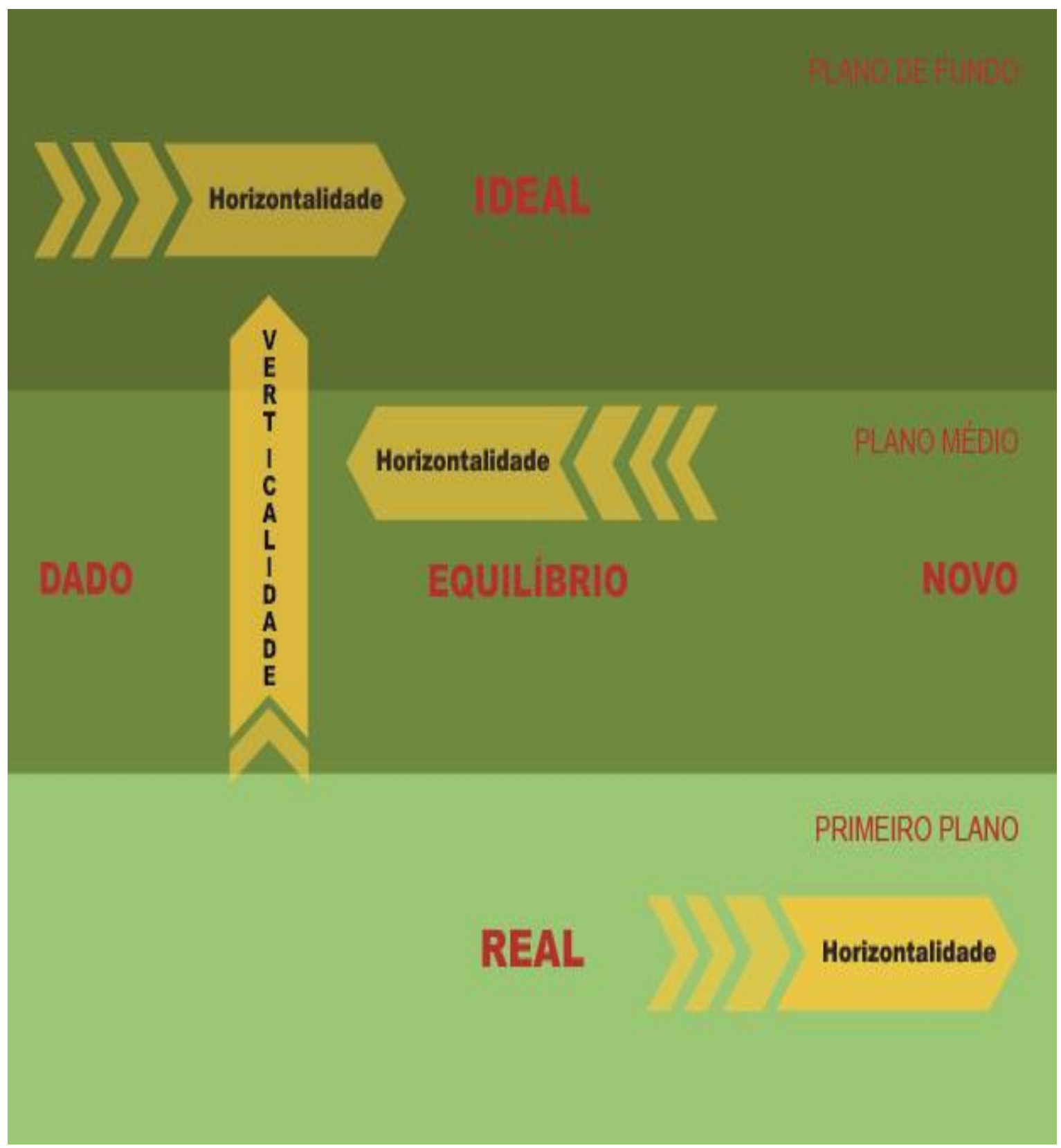

Fonte: Elaborado pela autora com base em van Leeuwen (2005).

Em uma estrutura narrativa, os significados realizam-se com base no peso, devido à relevância perceptual deste e também no campo visual dos elementos salientes na representação: o tamanho relativo, a nitidez de foco, a quantidade de detalhes, as texturas mostradas e o contraste entre áreas de alto contraste tonal entre o preto e o branco, entre cores altamente saturadas ou entre o vermelho e o azul que têm bastante relevância. A colocação desses elementos no campo visual 
torna-os mais pesados quando movidos para cima e quando movidos para a esquerda devido à assimetria no campo visual.

Em termos de perspectiva, os objetos colocados em primeiro plano de uma imagem são mais salientes do que os objetos de fundo, os elementos que se sobrepõem a outros elementos são mais salientes - fatores culturais específicos podem ser substituídos pela saliência perceptual de outros elementos. Em composições simétricas, à esquerda e a direita são equilibradas, mas o equilíbrio torna-se mais agitado quando um lado é visualmente mais pesado que o outro, pois o balanceamento do foco é deslocado para fora do centro geométrico do espaço. $O$ alcance e a manutenção do equilíbrio em situações de desbalanceamento são uma experiência básica que resulta de um senso de equilíbrio em todas as atividades humanas, incluindo as atividades semióticas (VAN LEEUWEN, 2005).

Os conceitos multimodais expostos acima têm sido utilizados para compor os significados de narrativas midiáticas, mas como o dado nunca é objetivamente dado, nem o novo objetivamente novo, as coisas podem ser tratadas como dadas ou como novas no contexto de uma situação ou de um evento comunicativo. Uma representação narrativa em que o meio é apresentado e salientado como essência idealizada ou generalizada da informação pode ser, exatamente, a parte da estrutura visual em que a ideologia opera com o propósito de moldar as ações sociais.

\subsubsection{Categorias da Multimodalidade}

Com base na compreensão de que, assim como o discurso, as semioses são um elemento significativo das práticas sociais por meio das quais os indivíduos agem no/sobre o mundo e as pessoas, representam os objetos, os lugares e as pessoas e se identificam com suas crenças, atitudes e valores (FAIRCLOUGH, 2003) e de que as análises textuais são de certo modo seletivas, as três categorias focalizadas a seguir, são relacionadas à luz da Teoria Semiótica Social da Multimodalidade. 


\section{Quadro 9 - Categorias analíticas da Multimodalidade}

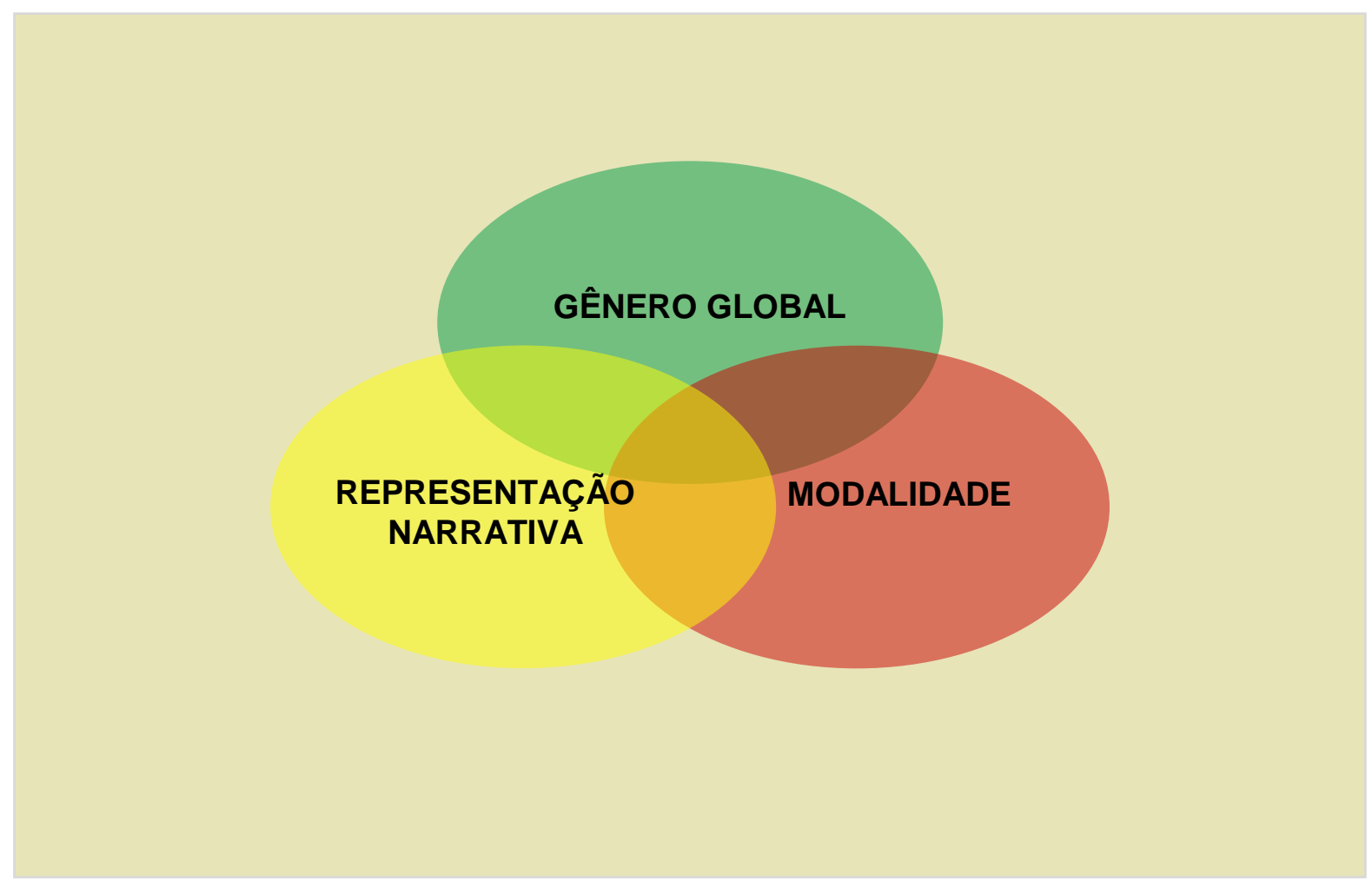

Fonte: Quadro elaborado pela autora com base em Machin e van Leeuwen (2007) e em Kress e van Leeuwen (2006).

\subsubsection{Gêneros globais}

Os gêneros globais são aqueles textos que promulgam e perpetuam as relações de poder em uma escala global. O que se tornou imediatamente óbvio tem de ser preservado nos gêneros globais, pois as relações de poder giram em torno daquilo que é essencialmente a mais importante função social como um todo. Isso envolve material produzido localmente com materiais importados. Estilos de layouts, por exemplo, são aspectos visuais preservados nos gêneros, pois por meio deles os jornais, as revistas e as páginas on-lines produzem e distribuem valores e estilos globais de vida (FAIRCLOUGH, 2003).

Gêneros com formato global têm o propósito da ação comunicativa orientada para construir um entendimento, um modo de ação proeminente na vida mundial. Os gêneros globais podem combinar-se com formas estratégicas de comunicação da vida moderna com o propósito de alcançar resultados. O gênero cujo formato é do tipo problema-solução tem como objetivo persuadir as pessoas. Em geral, o 
problema, expresso por uma pergunta, implica uma relação direta com o agente, e a solução, proveniente de uma ordem afirmativa apresenta o agente como solução. Os estágios do gênero global também são expressos por formas não verbais.

De acordo com David Machin e van Leeuwen (2007), os gêneros globais seguem a mesma ordem do discurso, mas são organizados por imagens: a imagem referente ao problema é seguida da imagem da solução. O gênero global do tipo problema-solução representado pela mídia tende a representar o problema verbalmente e a solução visualmente. As formas de comunicação cultural e específicas, as quais estruturam e estabelecem relações entre as partes que se comunicam, tornam-se modelos estratégicos para o exercício do poder. O exemplo a seguir é um modelo:

Figura 32 - Candidato à reeleição nos EUA Revista Newsweek, 1 a 8 de outubro de 2012

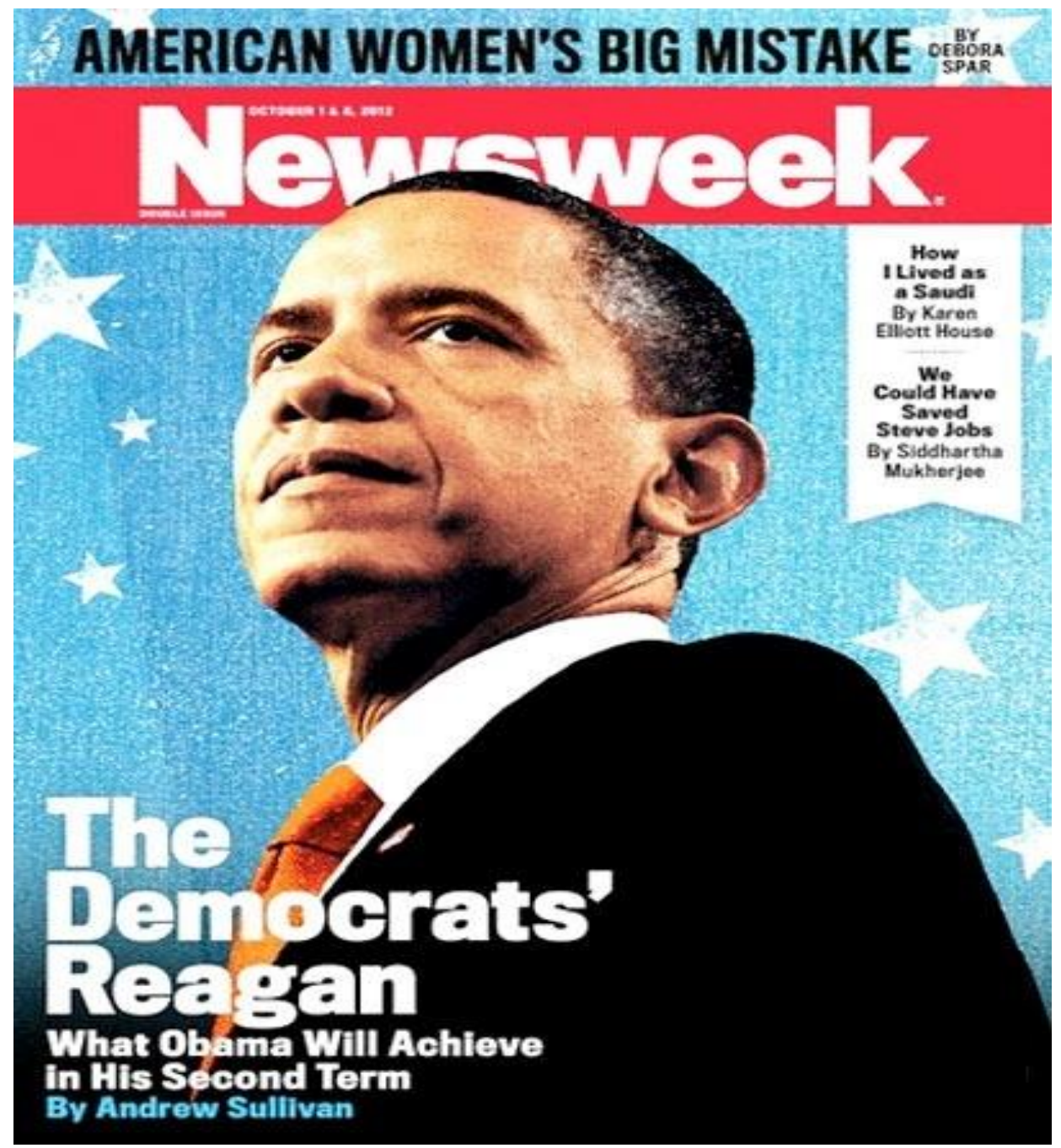

Fonte: Newsweek, Double Issue, capa. 
Neste texto, o participante, Barak Obama, candidato à reeleição para a Presidência nos Estados Unidos, é representado no primeiro plano da imagem, por meio de recursos semióticos da narrativização como o ângulo oblíquo que sugere inclinação e a postura elevada que sugere envolvimento com os receptores da imagem. Além disso, o olhar do participante para o infinito salientado pelo pano de fundo azul celeste (cor do partido dos democratas), em que aparecem estrelas sugerindo atemporalidade, cria estabilidade, estado de espírito que contribui positivamente para influenciar nos resultados de uma eleição.

Van Leeuwen (2005, p. 123) expõe que as narrativas midiáticas consistem em formas de ação e de interação desenroladas sequencialmente em estruturas sobre os eventos sociais. Com efeito, a análise das estruturas narrativas requer a percepção de ações instanciadas com palavras e com imagens. Fairclough (2012, p. 3), nesse sentido, enfatiza que formas/modelos, assim como os enunciados que internalizam lutas e conflitos sociais, estruturam e estabelecem relações ideológicas que influenciam o curso das histórias. Sendo assim, a análise crítica deve tomar as narrativas da mídia como construtos que servem como parte de ações econômicas políticas futuras, principalmente, quando representam pessoas de determinados modos e quando os argumentos práticos incorporados nelas são convincentes o bastante para desencadear processos de tomadas de decisões.

Relacionado aos gêneros globais está o pressuposto de Castells (2003, p. 139) segundo o qual a mente humana é capacitada para relacionar as formas problemas-resoluções e que a consciência surge a partir da necessidade de integrar o maior número de imagens a imagens da memória para expressão de ideias. Isso significa que quanto maior a capacidade de integração de processos mentais, maior a capacidade humana de utilizá-las para resolver problemas. Para Van Leeuwen (2005, p 123), a mente consciente precisa de um princípio de organização para orientar a atividade de resolução de problemas. Esse princípio é concebido como algo que é servido pelo processo de manipulação de imagens mentais. Isso implica analisar não apenas as ações instanciadas com imagens e com palavras, mas quem faz isso, porque faz, onde e quando faz, pois os textos contemporâneos podem disseminar ideologias manipuladas. 
Salientamos que os efeitos das narrativas multimodais dos significados das formas provenientes das lutas do Estado com outras economias competitivas, muitas vezes levam, por meio de políticas públicas, ao uso de processos de produção inadequados, de uma força de trabalho competitiva e excludente, que gera redução de responsabilidades para o enfrentamento da pobreza.

Pressupondo que as narrativas midiáticas estruturam e estabelecem relações entre as partes que se comunicam e que funcionam como modelos estratégicos usados no exercício do poder, o nosso intuito de investigar como são organizadas as narrativas ideológicas difundidas pela mídia contemporânea, encontra na análise da categoria gênero global uma forma precisa e adequada de análise.

\subsubsection{Representação narrativa}

As pessoas se comunicam e representam suas experiências e objetos do mundo dinâmico usando os sistemas semióticos representativos de sua cultura. Cada modo semiótico tem seu próprio meio particular de representar e de perceber conhecimentos, crenças, atitudes semelhantes e de combinar as modalidades da linguagem de diversas formas. Assim como a oralidade e a escrita, as linguagens não verbais representam pessoas, lugares, objetos, produzindo e reproduzindo significados de modo a satisfazer os interesses das instituições dentro das quais elas são produzidas (KRESS e VAN LEEUWEN, 1996, 2006).

A abordagem dos aspectos que diferenciam a produção do discurso da imagem contrasta as estruturas narrativas visuais e as estruturas conceituais. Enquanto os padrões narrativos servem para representar participantes, ações, eventos, processos de mudanças e arranjos espaciais transitórios, os padrões conceituais representam os participantes em termos de suas classes, estruturas e significados mais ou menos estáveis e atemporais.

Kress e van Leeuwen (2006, p. 47) afirmam que as estruturas narrativas visuais não são estruturas meramente formais, nem reproduções simples e fiéis da realidade; mas construções que possuem uma dimensão semântica profundamente importante. A marca de proposição narrativa visual é a presença de um vetor. $\mathrm{Na}$ 
linguagem, uma ação é realizada pela categoria verbo de ação. Na imagem, é traduzida por elementos formalmente definidos como vetores. $O$ que na língua se realiza por preposição locativa; na imagem, é expresso por características formais que criam o contraste entre primeiro e segundo plano, a sobreposição de gradientes de concentração e o grau de saturação na cor.

Os autores destacam que a distribuição de realizações e de possibilidades por meio dos modos semióticos é determinada por potencialidades e por limitações inerentes dos modos semióticos. Apesar de as culturas terem uma gama geral de possíveis relações que não estão vinculadas à expressão de qualquer modo semiótico particular e de algumas relações só poderem ser realizadas visualmente e outras só linguisticamente, a equivalência entre os participantes verbais e visuais nos gêneros visuais é essencial. Em manchetes de narrativas sobre acontecimento reais, textos e imagens aparecem juntos nas estruturas semânticas. A chave para compreender os textos reside, portanto, acima de tudo, no entendimento dos meios semióticos usados de forma heterogênea em um todo coerente.

\subsection{Participantes}

Kress e van Leeuwen $(1996,2006$, p. 48) expõem que há dois tipos de participantes envolvidos nos atos narrativos da comunicação visual: os participantes interativos e os participantes representados. Os participantes interativos são aqueles que falam, ouvem, leem e escrevem. Já os participantes representados são os que constituem o assunto da comunicação, as pessoas, os lugares e as coisas representadas na e pela fala ou escrita ou imagem, isto é, são os participantes de quem ou do que se fala, escreve e produz imagens.

Quadro 10 - Participantes da representação narrativa

\begin{tabular}{|c|c|}
\hline INTERATIVOS & REPRESENTADOS \\
\hline Ouvem e falam & Pessoas \\
Leem e escrevem & Lugares \\
Produzem & Coisas \\
\hline
\end{tabular}

Fonte: Elaborado pela autora com base em Kress e van Leeuwen (2006). 
O papel desempenhado por quem realiza a ação - o ator - relaciona os participantes de uma imagem por meio de um esquema transacional em que uns desempenham o papel de ator e outros desempenham o papel para quem a ação é feita, a meta. Estruturas narrativas que contêm participantes secundários são circunstâncias que podem ser ignoradas sem afetar a proposição básica do padrão narrativo. A situação, porém, é mais complexa para os participantes interativos reais, pois as imagens reais produzidas e visualizadas no todo do desenho podem não ser consideradas como idênticas aos implícitos que o produtor da imagem silenciosamente instrui aos espectadores, nem idênticas aos implícitos deles. Também pode ser que os próprios produtores e espectadores sejam explicitamente representados na imagem, fazendo com que os dois sombreiem um ao outro.

Duas formas de análise podem ser realizadas. A primeira é a Teoria da Arte (ARNHEIM, 1974, 1982), cuja linguagem é fundamentada na psicologia da percepção e a segunda, a Teoria Semiótica Social (HALLIDAY, 1978, 1985) aplicada à linguagem verbal. Na Teoria da Arte, os participantes são chamados de volumes e de massa e os processos de vetores ou de forças dinâmicas. Volumes são vistos como entidades distintas e salientes em diferentes graus por causa de seus diferentes tamanhos, formas, cores e assim por diante.

Na Teoria Semiótica Social, a análise volta-se para as funções semânticas. Termos como ator, vetor e meta são usados. Os atores desempenham os papéis mais importantes na estrutura gramatical. Em imagens, os participantes são identificados como importantes por meio do tamanho, da colocação na composição, do contraste contra o fundo, do grau de saturação da cor, da nitidez de foco e da saliência psicológica. Os participantes dos quais um vetor emana apontando para uma meta representam a relação como uma transação, como algo feito por um ator para um objetivo. Os participantes podem desempenhar os papéis de portador e de atributo. Nesse caso, o portador representa o todo e uma série de outros participantes, e os atributos possessivos representam as partes que compõem o todo. 


\subsection{Processos narrativos}

Processos narrativos visuais, segundo Kress e van Leeuwen (2006, p. 59), são caracterizados por ações, eventos, processos de mudança e por combinações espaciais transitórias. Os processos narrativos têm como sinal vetores que podem ser formados por ângulos, corpos, membros, objetos, linhas oblíquas fortes e diagonais de ação. Exemplificam os autores que, uma estrada sobre a qual um carro corre pode ser o vetor indicativo de direcionalidade e o carro dirigido, o participante ator no processo de condução. Linhas de conexão sem um indicador de direcionalidade formam um tipo particular de estrutura analítica que significa que algo está relacionado.

O potencial de vetores esquemáticos é amplo e abstrato. Pode ser difícil dizer, em palavras, os tipos de ação que os vetores representam, mas eles ilustram e explicam visualmente o que não está claro. Diferentes tipos de processos narrativos, segundo os autores, distinguem-se com base nos tipos de vetor e nos participantes envolvidos. Os processos narrativos agentivos podem ser transacionais, não transacionais, mentais e verbais. Apenas um processo narrativo não é agentivo, o processo de conversão.

Uma proposta visual narrativa com processo de ação transacional possui dois participantes, um é o participante ator e o outro é o participante meta. Os participantes são ligados por um vetor que os representa como fazendo algo para o outro. As representações narrativas com processos transacionais podem ser unidirecionais ou bidirecionais. Cada participante age no papel de ator em um momento e no papel de meta em outro momento. Em imagens que possuem apenas um participante, a estrutura de ação resultante é não transacional, porque a ação não é destinada a alguém ou a alguma coisa. É um processo análogo à ação do verbo intransitivo na língua. Mas pode existir um vetor e um participante para o qual a ação é dirigida.

Representações narrativas com processos que incluem apenas o um participante meta são eventos: algo acontecendo com alguém que não podemos ver ou saber o que faz acontecer, pois apenas uma pequena parte do ator é visível. Há, de fato, um participante ator, mas ele é excluído da representação. Essse processo 
visual é análogo ao processo linguístico em que não há menção sobre quem praticou a ação. Por exemplo, na manchete jornalística: "Quinze manifestantes foram mortos" o agente da passiva é excluído.

O participante ator de uma estrutura não transacional não é o participante ator que se move ou que instiga o movimento transacional e que levaria a um objeto (transportar ou enviar), porque a estratégia consiste em levar os consumidores a demandar os bens e os serviços, e não em oferecê-los. Nas estruturas visuais, o conteúdo substantivo colocado em primeiro plano impacta quem ou o que faz a ação

De acordo com Kress e van Leeuwen (2006), processos narrativos não transacionais podem projetar reações, um tipo de processo comportamental que têm apenas um participante humano realizando um campo de ação limitada. Quando o vetor é formado por uma linha de visão, pela direção do olhar de um ou mais participantes representados, o processo é reacional. Em vez de atores, os participantes são denominados reatores e em vez de metas, os participantes são denominados fenômenos. O reator, participante humano ou com aparência humana deve ter olhos visíveis e expressão facial. Em processos reacionais não transacionais não há fenômenos. O espectador de uma imagem elaborada com processo reacional pode imaginar que o reator esteja pensando ou olhando para ele. Isso pode criar um forte sentimento de empatia com os participantes representados na imagem. Imagens culturais para close-ups de participantes reatores de processos não transacionais, os quais olhem animados, desanimados ou confusos para algo que os espectadores não podem ver, tornam-se fontes de manipulação de representação, pois não é necessário dizer para o que o reator estava olhando quando a foto foi tirada. Esse tipo de manipulação é utilizado em textos da imprensa em que haja interesses políticos em jogo.

O fenômeno pode ser formado por outro participante, para quem ou o para qual o reator olha, mas também pode ser formado por um conjunto de proposições visuais, como exemplo, por uma estrutura transacional. Fenômenos realizados por participantes ou por estruturas inteiras definem processos mentais, ações e transações que podem não ter uma meta. Os processos mentais formam uma categoria menor na semiótica visual porque parece que não há dispositivos estruturais que diferenciem os processos cognitivos dos afetivos. 
Um tipo especial de vetor mental e verbal, segundo Kress e van Leeuwen (2006), pode ser observado por meio de balões de pensamento e de balões de diálogo. Assim como os processos transacionais, os processos mentais e verbais conectam seres humanos a certos conteúdos. Mas, em balões de pensamento e em dispositivos semelhantes, os conteúdos projetados são da percepção e da emoção e em vetores da fala, os conteúdos projetados são do discurso. Os conteúdos do pensamento ou da fala não são representados diretamente, mas mediados por um reator (o balão de pensamento) ou por um sensor (o balão de diálogo).

Os eventos podem ser representados com processos de conversão, como um ciclo em que um começo, um meio e um fim são encadeados. Estruturas narrativas não agentivas com processos de conversão possuem um terceiro tipo de participante que pode ser $\mathrm{o}$ ator em relação ao outro participante e a meta em relação a um participante. Esse tipo de participante, denominado relay, não se altera, pois o que recebe, transforma. Os eventos naturais geralmente são representados em diagramas. Quando a interação humana é representada como se fosse um processo natural, ela aparece com um evento natural

Kress e van Leeuwen( 2006, p. 69) esclarecem que as representações narrativas podem ser transacionais (unidirecionais ou bidirecionais) e não transacionais. Os processos de ações transacionais representam as pessoas e as coisas em termos materiais (fazendo algo) e processos não transacionais (acontecendo algo).

Em processos projetivos não transacionais, assim como em processos mentais e verbais, a pessoa ou o participante é representado como um fenômeno. A reação não transacional, de certa forma, é um processo comportamental, um tipo de processo que pode ter apenas um participante humano e que serve para realizar um campo de ação limitada. Fenômenos realizados por participantes ou por estruturas inteiras em imagens definem processos mentais, ações e transações que podem não ter uma meta. Uma reação transacional pode estar relacionada a um subconjunto do processo de percepção, porque os fenômenos não podem ser realizados diretamente no espaço semiótico. 
Os processos mentais formam uma categoria menor na semiótica visual, porque parece não haver dispositivos visuais estruturais para fazer a distinção entre cognição e sentimentos. É com base em critérios gramaticais que eles podem ser diferenciados em processos mentais (ver, ouvir, etc.), em processos de afeto (sentir medo, desejo, etc.) e em processos de cognição (saber, pensar, acreditar, etc.). Para se realizar, os processos verbais diferem de processos mentais porque eles precisam de um ser humano.

As ações não transacionais, por exemplo, podem representar circunstâncias como participantes secundários. Elas representam os eventos como se eles não tivessem relações além das que mantêm com o ator participante. Os diálogos em balões realizam três tipos de circunstância: localização, significações e acompanhamento. Esses tipos existem linguisticamente. Sendo assim, informações como o que, quem, quando, por que etc. devem ser consideradas na análise de uma estrutura narrativa visual (KRESS e VAN LEEUWEN, 2006). As estruturas narrativas não são difíceis de traduzir, mas requerem atenção. O quadro traduz o exposto:

\section{Quadro 11 - Configuração esquemática dos processos narrativos}

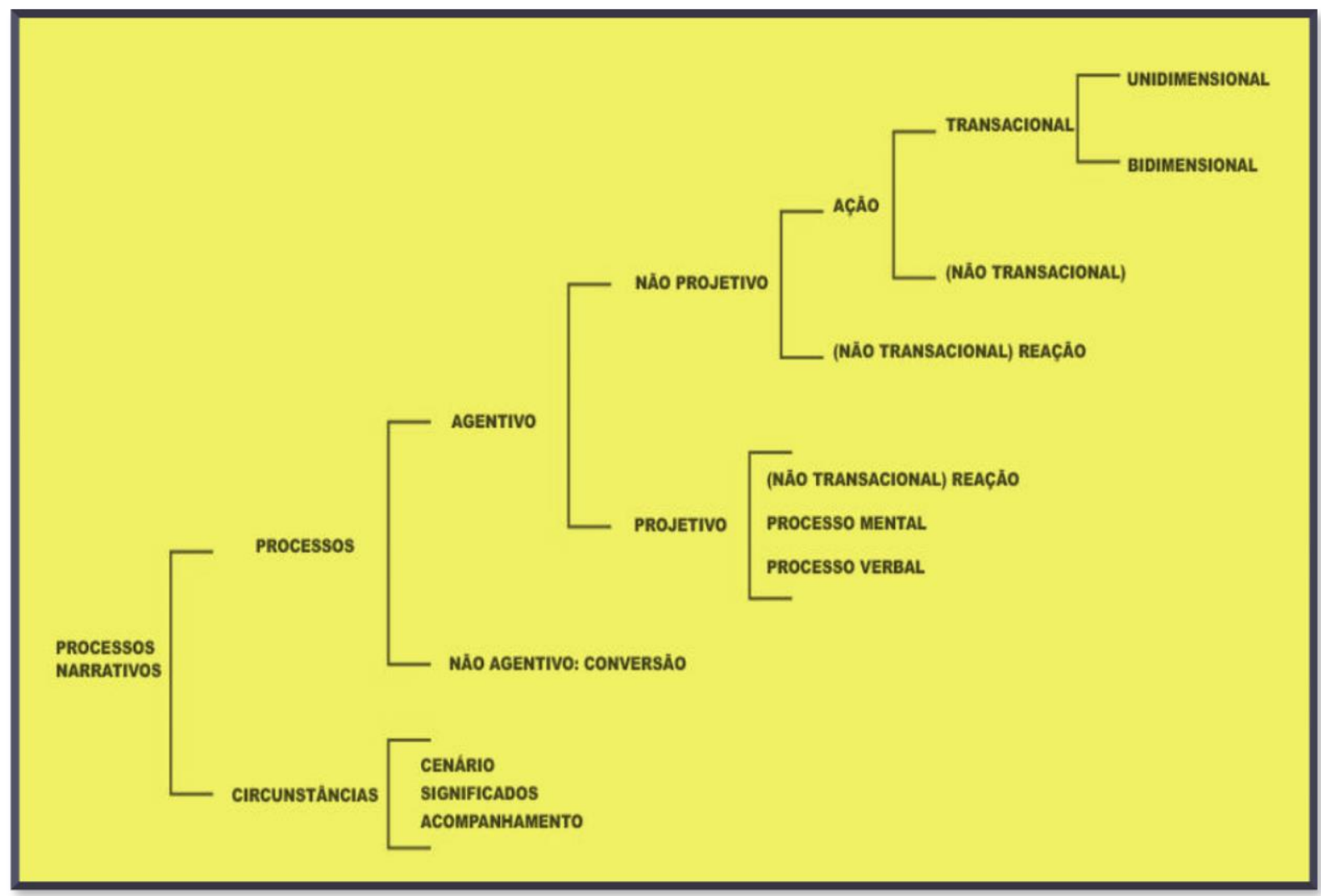

Fonte: Kress e Van Leeuwen, 2006, p. 74. Tradução da autora. 


\subsection{Circunstâncias}

As circunstâncias em imagens narrativas são participantes que podem ser ignorados sem afetar a proposição básica do padrão narrativo. Podem conter participantes secundários relacionados aos participantes principais por meio de outras formas, não de vetores. Existem três tipos de circunstâncias nas representações narrativas: as circunstâncias locativas, as circunstâncias de significados e as circunstâncias de acompanhamento. As circunstâncias locativas são as que relacionam outros participantes a um participante específico. É um processo reconhecível porque os participantes no primeiro plano sobrepõem-se porque são desenhados em menos detalhes, por causa da leveza entre o primeiro e o segundo plano ou do contraste na saturação de cor e escuridão total. A circunstância de significado de um processo é formada pelo vetor com o qual a ação é executada. A circunstância de acompanhamento é um participante da estrutura narrativa que não tem relação vetorial com os outros participantes e que não pode ser interpretada como um atributo simbólico.

Quadro 12 - Circunstâncias no padrão narrativo

\begin{tabular}{|l|l|l|}
\hline $\begin{array}{l}\text { Participante secundário relacionado a um } \\
\text { participante específico }\end{array}$ & & Circunstância Locativa \\
\hline Vetor do processo de ação & $\rightarrow$ & Circunstância de Significado \\
\hline Participante secundário da estrutura narrativa & $\longrightarrow$ & Circunstância de Acompanhamento \\
\hline
\end{tabular}

Fonte: Elaboração da autora, com base em Kress e van Leeuwen, 2006.

O contraste entre primeiro plano e plano de fundo realiza uma ou mais das seguintes formas: participantes sobrepostos no primeiro plano podem obscurecer o ajuste; cenário desenhado ou pintado com menos detalhes tem foco mais suave; cenário mais silencioso e dessaturado na cor tende ao uso de um mesmo tom de cor - geralmente o azul; cenário mais escuro é mais leve que o primeiro plano.

É importante destacar o que Kress e van Leeuwen (2006, p. 53) dizem sobre os significados produzidos em imagens por meio das formas geométricas básicas: 
quadrados, retângulos, círculos, triângulos e derivadas. Os quadrados e os retângulos, elementos da construção humana que dominam a forma das cidades, edifícios, estradas e de muitos dos objetos da vida, incluindo as fotos, representam honestidade, retidão e ordem. Ao contrário, os círculos, formas orgânicas vistas como autossuficientes e completas em si mesmas, representam imensidão, calor, proteção, eternidade e os céus. O triângulo, ao contrário do quadrado, é visto na perspectiva da multimodalidade como um elemento da ordem tecnológica. Especialmente quando inclinado, o triângulo, estrutura fundida de um participante e de um vetor, pode transmitir a direcionalidade, o ponto para as coisas. A linha reta significa linearidade, mas pode ser usada para uma vasta gama de significados compatíveis avaliados de forma positiva ou menos positiva, dependendo do contexto. Quanto mais abstrato o sinal, maior sua extensão semântica e seu potencial de utilização.

A angularidade é associada ao mundo da tecnologia, que, em princípio, é compreendido racionalmente. Formas curvas são as escolhidas por pessoas que pensam em termos de crescimento orgânico. Os sinais produzidos com os significantes da tecnologia e do natural são diferentes. O quadrado, por exemplo, conota a tecnologia positivamente, como fonte de poder e de progresso, mas dependendo do contexto, pode ser representado como fonte de opressão. Representada como uma ordem natural que evoluiu, a sociedade pode ser vista como a pequena comunidade unida em que todos sabem tudo sobre todos - o viés, então, é favorável à sociedade urbana moderna, por sua estrutura social mais ampla e libertadora.

Das formas básicas, derivam o quadrado, o círculo e o triângulo alongados horizontalmente ou verticalmente em diferentes graus e inclinados para a direita ou para a esquerda. $O$ alongamento vertical cria uma distinção mais acentuada entre os opostos e o alongamento horizontal um tipo de estrutura em que o que é posicionado do lado esquerdo é apresentado como informação de saída e o que é posicionado do lado direito como informação de chegada. Simbolismos geométricos são modelos de comunicação que não incluem participantes. Há apenas um vetor que indica a direcionalidade por meio de um sinal de infinito. Imagens desse tipo 
usam padrões pictóricos ou abstratos com processos cujos significados são constituídos por seus valores simbólicos.

\subsubsection{Modalidade}

A modalidade é uma categoria de análise da Teoria Semiótica Social da Multimodalidade essencial à nossa pesquisa porque descreve e analisa o que é real e o que não é real, o que é verdadeiro e o que é falso na comunicação visual, por meio de uma série de sinais especializados e de modos gerais de expressão usados para significar a verdade e a falsidade, a realidade e a ficção (VAN LEEUWEN, 2005).

Van Leeuwen (2005) aborda as perspectivas de análise da modalidade na comunicação visual. Do ponto de vista do naturalismo, a realidade é definida na correspondência entre a representação visual de um objeto em imagens, em fotografias e pelo olho nu. Do ponto de vista do realismo científico, a realidade é definida com base em como as coisas são, por entender que o olho teve uma formação cultural, que está localizado em um ambiente sócio-histórico, por conseguinte, o olho vê detalhes superficiais e diferenças individuais efêmeras. A realidade na perspectiva dos linguístas ou dos semioticistas é definida em termos de formas abstratas e de regularidades mais profundas. Finalmente, de acordo com definição sensorial da realidade, o prazer é o princípio dominante. As cores existem para serem vividas sensual e emotivamente, e é por esta razão que pessoas apreciam as cores saturadas e não as moduladas.

A credibilidade das narrativas midiáticas tem se baseado nas fotografias como uma representação naturalista codificada e convencionalizada da realidade, pois elas representam aquilo que é normalmente visível a olho, com profundidade, nitidez de detalhes (sombra e luz), definição e fundo. Todavia, como as fotoshops agora podem minar esse tipo de conhecimento, a verdade e a realidade estão sujeitas a dúvidas e a incertezas e, mais significativamente, a contestações.

O realismo encontra sua expressão na forma como a maioria representa 0 tipo de realidade, seja por meio de uma fotografia digital ou de um diagrama. Embora diferentes realismos existam lado a lado na nossa sociedade, o padrão 
dominante pelo qual julgamos a modalidade visual, por enquanto, é o naturalismo (o fotorrealismo como convencionalmente compreendido), que se baseia na aparência das coisas, na quantidade de correspondência entre o que podemos normalmente ver de um objeto em um cenário concreto e específico e o que podemos ver em uma representação visual, nas convenções e nas tecnologias de representação visual atualmente dominantes.

De acordo com van Leeuwen (2005, p.160), o realismo produzido por um grupo específico é um efeito das práticas complexas que definem e constituem esse grupo. Determinado tipo de realismo é, em si, um sinal da expressão dos valores, das crenças, dos interesses e das motivações desse grupo. Atualmente as definições da realidade estão ligadas às tecnologias da representação e da reprodução.

A mudança do domínio de preto e branco para o domínio da cor na comunicação visual, mostra o quão rapidamente as histórias das narrativas podem se desenvolver, pois a tecnologia e, mais ainda, a fotografia a cores, as define. Mas a mudança para a fotografia digital está criando um padrão naturalista com maior resolução e reprodução de cores. Uma diminuição no contraste, por exemplo, foi realizada para tornar aceitável esse padrão em muitos domínios. Uma imagem real é julgada quando as suas cores são quase tão saturadas como aquelas mais utilizadas pela tecnologia da fotografia-padrão. Quando a cor se torna mais saturada é vista como exagerada, excessiva. Quando menos saturada mais etérea. E o mesmo pode ser dito sobre outros aspectos da representação: a representação de detalhes, a representação de profundidade, e assim por diante. Figuras que têm perspectiva (achatamento ou profundidade), grau de detalhamento e tecnologia de fotografia a cores têm maior modalidade e são vistas como naturalistas. $O$ detalhe, a nitidez, a cor etc., podem ser reduzidas ou amplificadas para diminuir a modalidade.

Quanto mais é captado da representação das cores, menor é a modalidade. Há um contínuo que vai da saturação para a ausência de cor - o preto e o branco, em que estão apenas os valores de brilho da cor, a sua escuridão ou leveza contínua. Também existe um contínuo que funciona na diferenciação de cores, eventualmente, monocromáticas. A cor pode ser idealizada para maior ou menor 
grau - uma escala que vai da fotografia naturalista, através da escolha dos diferentes valores de uma cor, para a representação da luz e da sombra. Do ponto de vista naturalista, no entanto, a modalidade é diminuída em tais imagens. $O$ contínuo da cor modulada para cor normal é ao mesmo tempo um contínuo da alta à baixa modalidade. Em ambos os casos, a regra aplica-se: quanto maior a abstração, menor a modalidade (KRESS E VAN LEEUWEN, 2006).

\subsection{Marcadores de modalidade}

Uma série de sinais especializados e de modos de expressão usados na comunicação visual podem ser descritos e analisados, conforme a perspectiva naturalística, nas formas de comunicação veiculadas pela mídia com adequação e precisão. São eles: a cor, a contextualização, a representação, a profundidade, a iluminação e o brilho.

Cor

A cor, uma importante marca de modalidade utilizada nas imagens, pode ser analisada, em termos de três escalas: da saturação da cor, da diferenciação da cor e da modulação da cor. A saturação pode ser marcada em uma escala que vai da cor completamente saturada para a ausência de cor (o preto e o branco). Veja o exemplo: 
Quadro 13 - Escala de modalidade (saturação da cor)

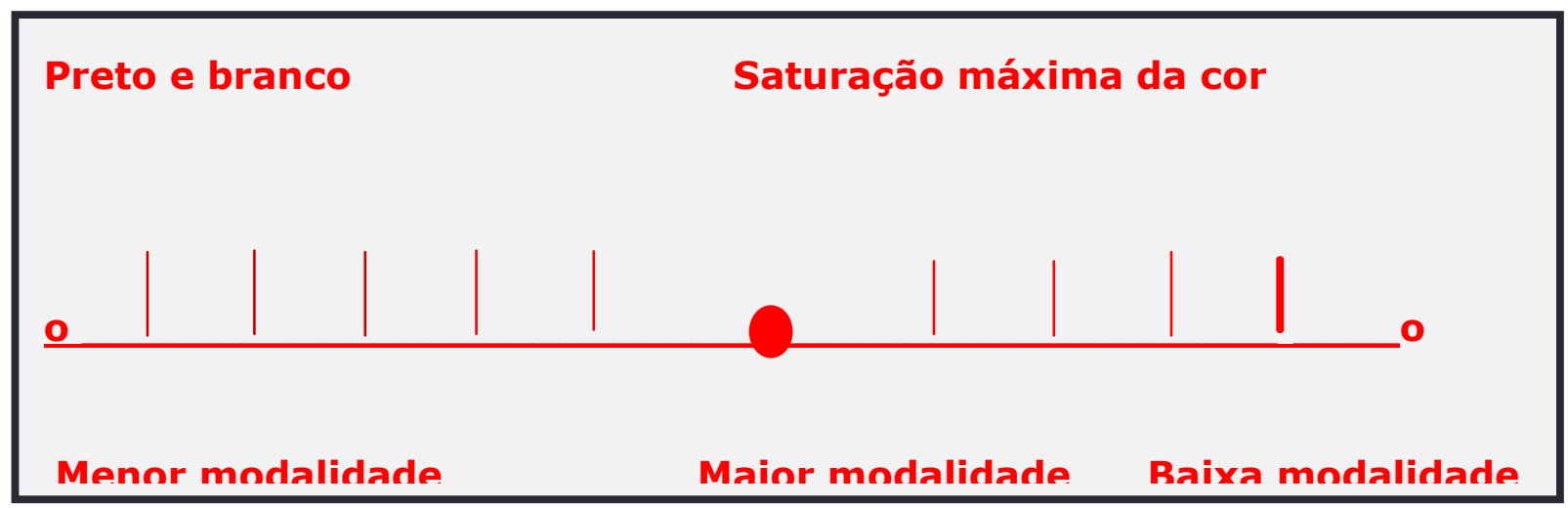

Fonte: Kress e van Leeuwen (2006, p.160).

A diferenciação, em uma escala, vai de uma gama de cores maximamente diversificadas para o monocromático. A modulação da cor é marcada em uma escala que vai de cores totalmente moduladas (muitos tons diferentes de vermelho) a cores não moduladas. Em uma das extremidades destas escalas, a dimensão particular da cor é maximamente reduzida. Na outra extremidade, é mais inteiramente articulada e utilizada para o seu potencial máximo. Cada ponto da escala tem certo valor de modalidade em termos da norma naturalista. No entanto, o ponto maior da modalidade não coincide com os extremos da escala: a modalidade naturalista aumenta à medida que a articulação aumenta, mas, em certo ponto, ela atinge seu mais alto valor e depois diminui novamente.

Contextualização

A contextualização pode ser marcada em uma escala que vai da ausência de plano de fundo para um fundo mais plenamente articulado e detalhado. Dentro da orientação de codificação naturalista, a ausência de configuração reduz a modalidade. Quando descontextualizada, a imagem mostra um vazio, os participantes são representados genericamente ligados a uma localização específica e a um momento específico no tempo. A escala de contextualização vai da contextualização completa para o fundo liso não modelado. Na contextualização completa, configurações fora de foco podem ser encontradas em maior ou menor 
grau. Detalhes visuais na representação se perdem por meio da sobre-exposição, resultando em uma espécie de brilho etéreo ou por meio da subexposição, resultando em escuridão barrenta. Além disso, a descontextualização pode ser alcançada por meio de elipse, com alguns adereços sugerindo uma configuração. Talvez o fundo possa mostrar apenas um padrão irregular de luz e de sombra, ou um campo de cor não modulada, ou preto, ou branco. O fundo totalmente articulado não tem a maior modalidade naturalista. As limitações impostas pelo padrão fotográfico, pelas emulsões e pela profundidade de campo das lentes produzem imagens em que o fundo é menor do que o primeiro plano articulado. Quando o fundo é mais nítido e definido do que isso, a impressão do real é um pouco artificial.

\section{Representação}

A representação vai da máxima abstração para a máxima representação de detalhes pictóricos. Uma imagem pode mostrar todos os detalhes dos participantes representados: os fios individuais de cabelo, os poros da pele, os vincos na roupa, as folhas individuais de uma árvore, e assim por diante, ou pode abstrair pormenores, em maior ou menor grau. Existe um ponto além do qual um aumento de detalhes torna-se hiper-real, portanto, menor em modalidade do ponto de vista do naturalismo fotográfico. Da mesma forma, a representação reduzida de detalhes (descontextualização) pode formar um modo em que a modalidade de fundo é menor que a modalidade de primeiro plano. Na fotografia, a nitidez de foco e a exposição podem reduzir detalhes.

\section{Profundidade}

A profundidade pode ser marcada em uma escala corrida de ausência para o máximo de profundidade. Pelos critérios do naturalismo-padrão, a perspectiva central tem maior modalidade, seguida por perspectiva isométrica angular, seguida por perspectiva isométrica frontal, seguida pela profundidade criada pela sobreposição. Mais uma vez, a perspectiva pode tornar-se mais que real, como quando forte convergência de linhas verticais é mostrada, ou uma perspectiva de "olho de peixe" é usada. 
lluminação

A iluminação, em uma escala corrida, vai da representação mais completa do jogo de luz e de participantes afetados por determinada fonte de iluminação à abstração da luz. Poucas imagens naturalistas podem abstrair a iluminação e mostrar sombras, apenas na medida em que são necessárias para modelar o volume, especialmente de objetos redondos. Elas têm "sombreamento" em vez de sombra ou usam o sombreamento para indicar recuos, destaques e áreas salientes, muitas vezes, de maneira que não têm explicação em termos da lógica de iluminação. Isso pode ser feito em diferentes graus: com escurecimento totalmente modulado em áreas de sombra; com apenas dois graus de brilho em áreas iluminadas e um grau para áreas sombreadas; com pontilhado mais ou menos denso das áreas sombreadas; e assim por diante. No extremo da escala, a luz e a sombra são abstraídas do conjunto. Em vez do sombreamento, uma linha é usada para indicar os contornos de recuo.

Brilho

O brilho, em uma escala contínua, vai de um número máximo de diferentes graus de luminosidade para apenas dois graus: preto e branco, ou cinza escuro e cinza mais claro, ou dois valores brilhantes da mesma cor. Valores de brilho podem contrastar em maior ou menor grau. Em uma foto, a diferença entre a área mais escura e a área mais clara pode ser muito grande e, em outra foto, a diferença pode ser mínima, de modo que um efeito nebuloso é criado, mas a capacidade de a fotografia tornar-se preto e branco é limitada, bem como a sua capacidade de diferenciar valores de brilho. A gama de contraste e de valores de brilho que excede essa capacidade pode ser experimentada como mais do que real e, portanto, como sendo de menor modalidade.

A modalidade, como vimos, é realizada por uma complexa interação de pistas visuais. A mesma imagem pode ser abstrata, em termos de um ou de vários marcadores, e naturalista, em termos de outros. Pode parecer que a realização da modalidade em imagens é muito mais complexa e especializada do que a realização da modalidade na linguagem. Na realidade, a linguagem, também, permite combinações complexas de diferentes sinais de modalidade, mas como há mais 
contradições na linguagem, o valor de pistas da modalidade depende do contexto. Isso implica reconhecer que o exercício do poder e da dominação encontra na diversidade dos sinais de modalidade uma fonte propícia aos seus intentos. Sejam os efeitos das formas midiáticas que narrativizam as situações e os eventos comunicativos ideológico, sejam eles não ideológicos, somente a análise crítica semiótica, textualmente orientada, poderá revelar os significados nelas compostos.

\subsection{Análise de Discurso Crítica (ADC)}

A Análise do Discurso Crítica (ADC) de vertente britânica é uma perspectiva teórica proposta por Norman Fairclough, Van Dijk, Theo van Leeuwen, Wodak e outros estudiosos dos fenômenos da linguagem, a qual tem como conceito basilar o fato de que a língua é parte irredutível da vida social. A ADC não polariza o conhecimento, mas a sua posição sociopolítica é explicitamente definida e defendida.

Herdada da Linguística Crítica, cuja filosofia se assenta na ontologia do Realismo Crítico de Bhaskar (1989), a Análise de Discurso Crítica constitui-se originalmente da noção de construtivismo estruturalista do sociólogo Pierre Bourdier (1973), segundo o qual a vida social influencia as estruturas sociais e é influenciada por elas, mediante um processo simbólico de imposição de sistemas e de estruturas mentais ajustadas às estruturas sociais.

A ADC estabelece-se com base na Linguística Sistêmica Funcional (HALLIDAY, 1991), teoria da linguagem que enfatiza o uso multifuncional desta como forma de ação, de representação e de identificação social. Fairclough (2003), descreve-a como abordagem de linguagem de cunho social que possui método de análise explanatória textualmente orientada.

A ADC relaciona-se com abordagens concentradas em problemas sociais, especialmente, com aquelas preocupadas com a reprodução e com o uso do poder, na perspectiva do que é consistente com os interesses dos dominados. Significa que a teoria leva a sério e, em consideração, as opiniões e as experiências dos membros socialmente desfavorecidos, apoiando a luta contra a desigualdade e a opressão. A explanação dos significados subjacentes nos textos e nos artefatos que circulam no 
mercado capitalista consumidor resultam da aplicação de conhecimentos rigorosos, de descrições precisas e de análises criteriosas, válidas e confiáveis (WODAK 2003, 144).

O que vem propiciando o desenvolvimento progressivo da Análise de Discurso Crítica é o diálogo mantido com as ciências que consideram a complexidade das relações entre as estruturas linguísticas e as sociais, que levam em consideração as opiniões e as experiências dos grupos em situação de desigualdade ou desvantagem e que veem o discurso e as semioses como elementos das práticas sociais que contribuem para as mudanças sociais.

De acordo com Fairclough (2003), os textos são concebidos como parte de eventos sociais por meio dos quais as pessoas agem e interagem no curso dos eventos. As formas interdiscursivas materializadas nos textos, segundo o autor, são formas de (inter) ação, de representação e de identificação de aspectos do mundo em que diferentes modos da ideologia podem ser incorporados para servir ao poder e à dominação. Chama-nos, atenção, Fairclough (2003, p. 83), para o fato de os impressos estarem criando histórias de séries de eventos relatados cronológica e logicamente, como uma forma de regulação social, ou mesmo como uma forma de violência. Os jornais reduzem uma série de eventos complexos que constituem uma história, impondo uma ordem narrativa sobre eles. Acontecimentos reais originalmente relatados são produzidos como um evento diferente e separado. Coisas que foram ditas oralmente são excluídas da produção da história e relações particulares são incluídas, de modo que o texto se apresenta de modo fragmentado e mal definido.

A série de eventos colocados na narrativa jornalística em uma sequência diferente da cronológica real (a representação de uma ação anterior focalizada no texto como posterior) provê posições de saliência para a focalização de ideias que se destacam nas manchetes e nos primeiros parágrafos do texto. No entanto, essas posições de saliência são motivadas pelos modelos de contexto envolvidos na produção do gênero. Isso aponta para a importância de as narrativas jornalísticas serem vistas não como simples relatos de fatos, mas como resultado de um processo altamente interpretativo e construtivo, como um modo de controlar ou regular os eventos e as formas por meio das quais as pessoas agem em resposta 
aos eventos. O fato é que além de as narrativas jornalísticas terem uma intenção referencial que abre questões de verdade, elas possuem uma intenção explanatória que leva a focalização de ideias, fazendo com que os eventos constituam significados que incorporam pontos de vista particular.

Narrativas midiáticas devem informar às pessoas sobre o que de significativo têm acontecido no mundo. Mas os meios de comunicação funcionam de maneira a, atender aos interesses das corporações que os subsidiam e, desarte, garantindo maior espaço ao poder. Histórias com propostas de alto nível, por exemplo, conectam-se à política internacional e podem ir além das relações sociais da mídia local, das relações entre jornalistas e audiências, das relações dissimuladas entre governantes e governados e entre o governo e os negócios de outras pessoas. Sendo assim, é importante analisar como o gênero discursivo tem sido organizado.

As mudanças e as transformações sociais realizadas, em parte, pelo discurso globalista associado ao capitalismo, levam os Estados-Nação, como entidades soberanas legítimas, a promover suas imagens, via os meios de comunicação de massa, para o exercício do poder de governança. Assim como os processos promocionais usados em textos publicitários, os gêneros de governança ligam os gêneros do governo local com os gêneros empresariais, servindo como como elo crucial de mediação para flexibilizar procedimentos de governança. As narrativas imaginadas, por exemplo, recontextualizam com relativa facilidade eventos socioculturais para o exercício da governança (FAIRCLOUGH, 2006).

Contudo, para alcançarem hegemonia, as narrativas midiáticas dependem de vários fatores. Primeiro, depende da seletividade estrutural, pois há estruturas mais abertas para o uso de estratégias que outras. Segundo, dependem da economia baseada em um conhecimento que requer a articulação de outros discursos. Terceiro, dependem de que as mensagens que elas evocam sejam mediadas pelos meios de comunicação e acessadas pelo público. Em quarto lugar, elas dependem da capacidade do discurso mobilizar pessoas e ter ressonância com os seus receptores (FAIRCLOUGH, 2006). Contudo, acreditamos que mesmo narrativas globais consideradas bem-sucedidas podem ter efeitos causais complexos sobre as ações sociais porque ressoam como reproduções fiéis da realidade. Isso implica reconhecer que algumas, por suas características 
promocionais, podem levar pessoas a investir tempo, energia, dinheiro e outros recursos no sentido mais amplo, comprometendo outros investimentos.

\title{
3.2.1 Narrativas jornalísticas: uma perspectiva crítica
}

\begin{abstract}
Precisamos perguntar se a distinção entre narrativas jornalísticas e as narrativas ficcionais é realmente clara: as estéticas das narrativas jornalísticas parecem tornar-se um problema cada vez mais saliente, às vezes, à custa de suas responsabilidades diante dos acontecimentos reais, ao mesmo tempo em que assumem ponto a ponto papel psicológico social de inocular-nos do medo e das ansiedades entorpecentes de um mundo perigoso. (FAIRCLOUGH, 2003, p. 86.)
\end{abstract}

As narrativas jornalísticas de editoriais políticos, econômicos e sociais devem ser produzidas em linguagem direta e objetiva, de modo a manter a proximidade com o referente e a ter efeitos de veracidade. Narrativas do tipo problema-solução estão geralmente relacionadas a aspectos importantes da realidade, como à política internacional, às relações sociais secretas entre governantes e governados, entre jornalistas e público e entre governo e empresas. Entretanto, não é raro aparecerem nos impressos com características similares às de fábulas de fundo moral ou providencial. E é dessa forma que elas competem para as oportunidades que surgirão.

A análise da narrativa jornalística proposta por Fairclough (2003) baseia-se na narratologia de Mieke Bal (1997, 2009), uma abordagem que distingue o texto narrativo da história e da fábula. O texto narrativo é definido como uma estrutura finita composta de sinais linguísticos, visuais e sonoros que possui funções e significados e que é produzida por um agente que transmite uma história a um destinatário, por meio da linguagem verbal, de imagens, sons, artefatos, ou da combinação destes meios. A história, por sua vez, é vista como o conteúdo do texto narrativo produzido de maneira particular, mas com a coloração de uma fábula. $A$ fábula, por fim, é concebida como uma série de eventos causados e experienciados pelos atores (não necessariamente humanos), os quais são relatados, lógica e cronologicamente, por um narrador. Essa distinção não induz ao sentido de 
independência de um aspecto da narrativa em relação ao outro; mas sugere que a descrição do texto narrativo seja desassociada da história, porque a narrativa não é idêntica à história originalmente relatada e porque o procedimento é útil ao estabelecimento da estrutura textual em que o conteúdo é processado.

O material da fábula sempre contém, além da série lógica de acontecimentos, os atores relacionados aos eventos, o espaço real ou imaginário e o tempo, no seu estado hipotético, porque o tempo não é relevante para a lógica interna da fábula. Os processos que distinguem uma fábula das histórias são vários: os eventos dispostos em uma sequência diferente da cronológica; o tempo ocupado pelos eventos das histórias; os atores individualizados e transformados em personagens; os locais onde ocorreram os eventos, depois transformados em lugares específicos; as relações necessárias entre os agentes da fábula e outros relacionamentos (simbólico, alusivo, tradicional etc.) existentes; e a escolha feita entre os vários "pontos de vista", com base nos quais elementos podem ser apresentados, pois a focalização resultante, da relação entre "quem percebe" e o que é percebido, é o aspecto que colore a história com subjetividade. A organização desses elementos na história, pelo autor, é o que produz o efeito desejado: convincente, comovente, desagradável ou estético (BAL, 2009).

A narrativa, história produzida e transmitida por um agente, não identificado como escritor, pintor, compositor ou cineasta, mas como narrador, pode ser temporariamente transmitida aos destinatários, através do discurso direto, por um dos atores. Isso significa que, além da descrição de aspectos da narrativa, é relevante determinar quem está fazendo a narração. Ademais, um texto não consiste apenas de narração, no sentido específico. Assim, é importante observar o que é descrito e opinado no texto. Dessa forma, é possível melhor classificá-lo e identificar a verdade estética da narrativa (BAL, 2009).

Fairclough (2003, p. 83) resume que a fábula envolve os seguintes aspectos: o arranjo dos eventos em uma sequência que pode ser diferente da ordem cronológica original, o tratamento dos agentes dos eventos reais de modo a transformá-los em personagens e a focalização de aspecto em termos de um ponto de vista particular. O leitor da história narrada lê o texto, não a fábula. Porém, como resultado de uma interpretação influenciada tanto pelo narrador do texto, quanto 
pela leitura do leitor e pelas manipulações da história, o traço de memória que permanece após a leitura do texto é o da fábula. A história relatada pode aparecer em um conjunto de textos particulares (em filmes, em narrativas de conversas e de rádio, em documentários etc.).

A análise da narrativa proposta por Fairclough (2003) envolve a análise da categoria gênero discursivo por ser uma condição segura para a investigação de como as narrativas se organizam e que significados discursivos elas acionam.

\subsubsection{Gênero discursivo como categoria de análise}

De acordo com a Análise de Discurso Crítica, os gêneros discursivos são formas de ação e interação definidas pelas práticas realizadas nos eventos sociais, que estruturam os textos por meio de relações léxico-gramaticais, de incorporação de outras vozes e de outros textos. Os gêneros do discurso não são homogêneos. Eles variam em termos das tecnologias de comunicação, em termos dos propósitos das atividades que constituem (alguns visam ao entendimento outros a alcançar um resultado) e em termos de grau de estabilização e de fluxo. Nesse sentido, alguns chegam a ser quase ritualizados, outros totalmente flexíveis (FAIRCLOUGH, 2003, p. 68).

Diante da complexidade que essa variabilidade ocasiona à análise dos gêneros, Fairclough (2003) propõe uma classificação terminológica que os diferencia em termos de grau de abstração. Os gêneros mais abstratos, estabilizados e que transcendem as redes particulares de práticas sociais são denominados pré-gêneros (narração, argumentação, descrição, conversação). Os gêneros mais ou menos abstratos, desenvolvidos nas redes particulares de comunicação e que também transcendem diferentes redes e escalas (reportagens, notícias e entrevistas) são os gêneros desencaixados. Os gêneros desencaixados - formas discursivas desenvolvidas de práticas sociais derivadas de processos globais - que envolvem a reestruturação e a reescalada do capitalismo e que, portanto, transcendem diferentes redes de comunicação e escala como uma espécie de tecnologia. $E$ os gêneros estabilizados nas práticas de redes particulares de comunicação são os denominados gêneros situados (as consultas terapêuticas, os relatos de experiências, etc.). 
Quadro 14 - Gênero discursivo

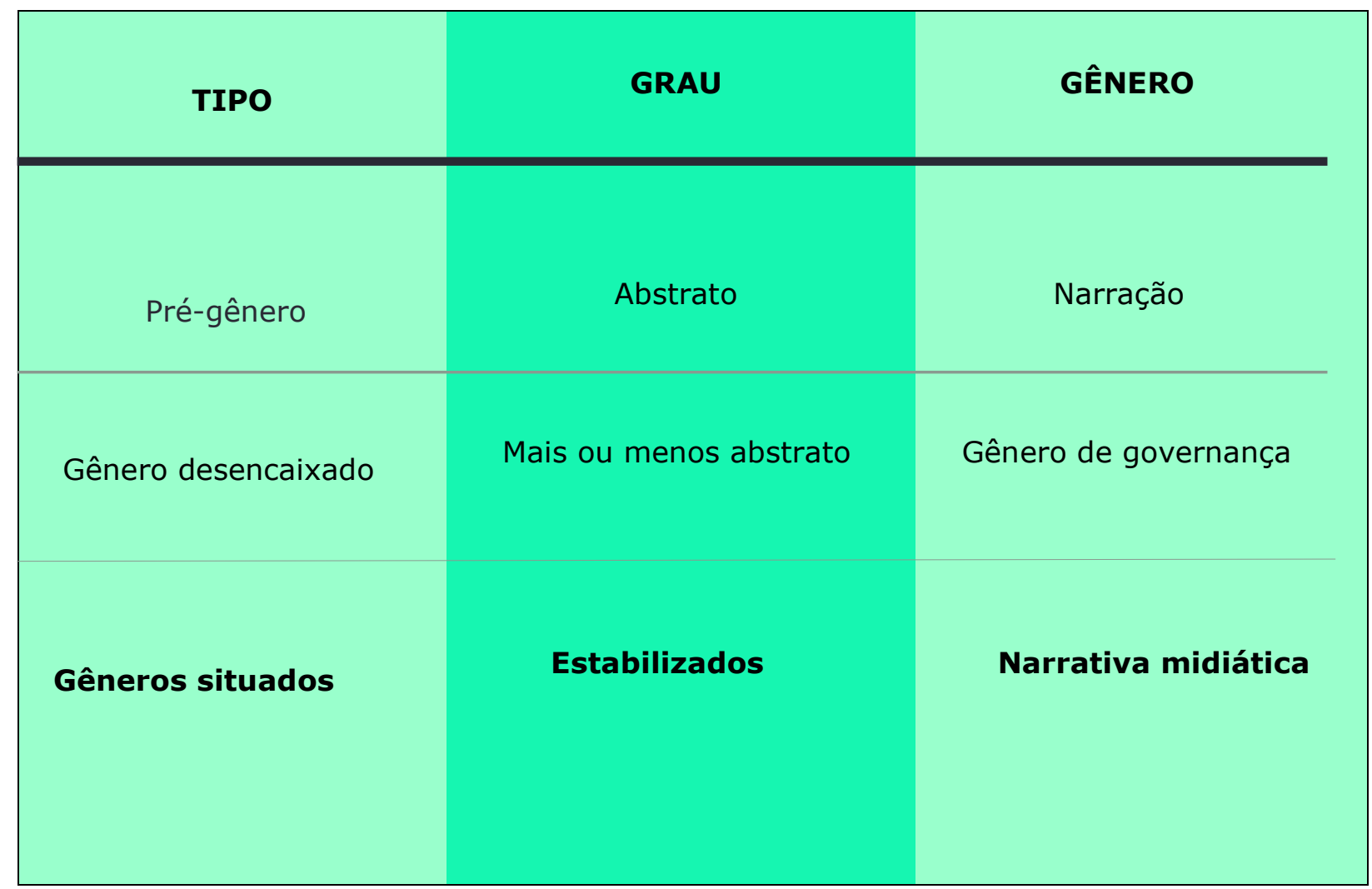

Fonte: Elaborado pela autora com base em Fairclough (2003).

A narração, estrutura genérica de mais alto nível de abstração assim como a argumentação e a conversação, é concebida como um pré-gênero que estrutura as narrativas. Isso justifica a semelhança existente entre as narrativas imaginadas e as narrativas jornalísticas contemporâneas, muito embora atividades e propósitos diferenciem-nas, na medida em que uma visa à criação como fruto da imaginação e a outra à retratação da realidade.

A diferenciação da estrutura genérica proposta por Fairclough (2003, p. 68) possibilita analisar o encaixamento de textos-imagens em narrativas veiculadas pela mídia. No contexto da globalização, esse processo (GIDDENS, 2002) tem sido um eficiente mecanismo na organização de textos particulares, porque legitima relações de poder, garantindo efeitos de sentido.

De acordo com Fairclough (2003, p.33) as narrativas mediadas pela mídia de massa são formas de ação e de interação que funcionam como parte do aparelho de governança, por intermédio das novas tecnologias de comunicação de modo que, em sua organização genológica alguns discursos são privilegiados em detrimento de 
outros. O aumento de gêneros promocionais deve-se ao capitalismo novo, pois são os tipos que chamam a atenção e atraem investimentos. Como os gêneros promocionais, as narrativas promovem imagens, transformam outras práticas sociais, mas também podem ser transformadas por diferentes práticas, mediante processos de recontextualização. Os textos abaixo são exemplos concretos.

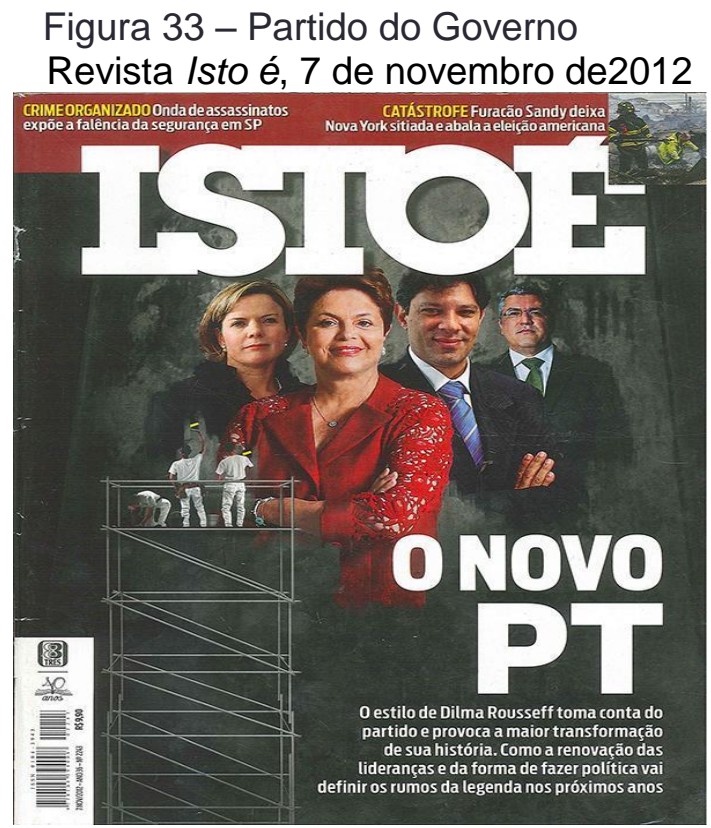

Fonte: Editora Três, ano 36, n. 2.242.
Figura 34 - Primeiro-ministro da Espanha Revista Tiempo, 17 de junho de2013

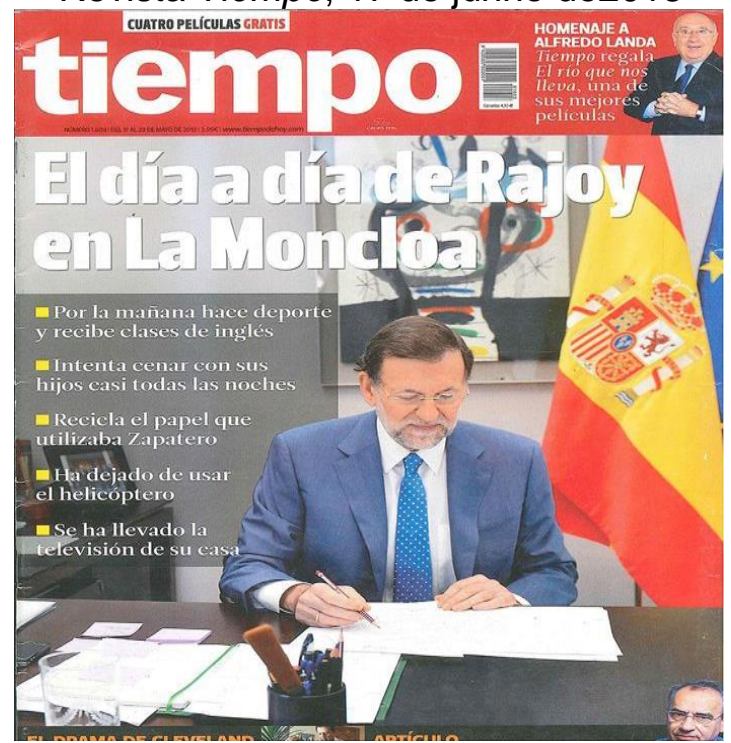

Fonte: Grupo Zeta, n. 1.603.

Princípios da recontextualização, como as ações dos agentes representados no texto e a proeminência de aspectos concretos são analisados em gêneros discursivo como esses. No texto 1, agentes políticos são incluídos com proeminência de aspectos. Nesse caso, o evento real (o surgimento d'O NOVO PT), representado pela expressão facial e pela postura dos participantes, tem como meta atrair a atenção do público receptor para o partido político do Governo Brasileiro. No texto 2, o destaque é dado à ação cotidiana do participante da narrativa (o Presidente da Espanha) representado como meta.

$\mathrm{Na}$ realidade, todo discurso recontextualiza práticas sociais e todo conhecimento é fundamentado na prática social. Sendo assim, os princípios de recontextualização estão ligados às práticas sociais: ações dos atores e seus papéis, estilos e configurações. Contudo, os processos semióticos que recontextualizam mensagens anteriormente produzidas e difundidas podem transformar aspectos dessas mensagens. O conhecimento produzido pela mídia 
com base nos gêneros tem sido divulgado com mudanças semânticas e de acordo com orientações que selecionam e relacionam outros discursos para constituir sua própria ordem e ordenação. Ações que legitimam ou que deslegitimam identidades sociais, por exemplo, são aspectos ideológicos geralmente mobilizados na recontextualização de gêneros.

Uma vez que nossa pesquisa crítica transdisciplinar baseia-se na noção triádica, discurso - cognição - sociedade, o diálogo entre Teorias da Linguagem e Teorias Sociais torna-se essencial. Com efeito, tratamos da Ideologia à luz da perspectiva sociocomunicativa de Thompson (2011), isto é, como um princípio de funcionamento dos textos que se materializa por meio de modos de operação estratégicos, como abordado no segundo capítulo desse estudo.

\subsection{Teoria Sociocomunicativa da Ideologia}

Concebida originalmente como uma ciência superior que serviria de base para o conhecimento científico geral e que facilitaria a regulação natural da sociedade em particular, a ideologia tornou-se uma teoria e suas exigências filosóficas ficaram comprometidas devido a associações com um corpo de ideias supostamente separadas das realidades práticas da vida política.

A ideologia, segundo Karl Marx, relacionava-se aos sistemas políticos, morais e sociais estabelecidos pela classe social dominante para manter os ricos no controle da sociedade e sustentar o status quo. O conceito de ideologia preservou o sentido negativo nas disciplinas que emergiram das ciências sociais, mas foi neutralizado de várias maneiras pelo interesse na elaboração de estratégias de luta das classes dominantes.

Thompson (2011) entende ser correto ver as relações de classe como base para as desigualdades sociais, mas segundo o autor, a perspectiva tradicional da ideologia não percebe que as classes determinadas por relações objetivas de produção e por circunstâncias de caráter econômico dependem necessariamente de formas simbólicas apropriadas aos seus interesses e objetivos. Isso implica a 
impossibilidade de tratar adequadamente da natureza e do impacto das comunicações no mundo atual.

A perspectiva crítica da ideologia, alternativa que ultrapassa o caráter histórico de seu estudo, atribui às formas simbólicas uma interpretação particular. A ideologia é vista como algo negativo, crítico ou pejorativo, porque ela serve para reforçar pessoas e grupos que ocupam posições de poder. De acordo com Thompson (2011), em circunstâncias particulares, os modos da ideologia operam nas formas simbólicas para estabelecer e para manter relações de poder e de dominação. As formas simbólicas produzidas por agentes situados em contextos sócio-históricos específicos e dotados de recursos e de capacidades de vários tipos podem carregar os traços de diferentes maneiras das condições de sua produção.

Destacamos o que diz o autor:

A inserção das formas simbólicas em contextos sociais implica, que, além de serem expressões de sujeitos, são, geralmente recebidas e interpretadas por indivíduos também situados dentro de contextos sócio-históricos específicos e dotados de vários tipos de recursos. $\mathrm{O}$ modo como uma forma particular é compreendida pelos indivíduos pode depender dos recursos e das capacidades empregadas no processo de interpretação. (THOMPSON, 2011, p. 193.)

Entendemos que a inserção de modelos de contextos nas formas de (inter)ação mediadas pela mídia é o que as transforma em objeto de complexos processos de valorização, de avaliação e de conflito. Logo, análises contextuais das formas sociocomunicativas valorizadas e contestadas pelos indivíduos que as produzem e as recebem é essencial à interpretação adequada dos significados ideológicos produzidos nas representações narrativas estetizadas da mídia contemporânea.

É interessante destacar o que pensa Roger Fowler após analisar o papel ideológico desempenhado pela imprensa:

[...] a ideologia ajuda a constituir a realidade de ângulos específicos. [...] é um processo encontrado em todo discurso: a mediação estruturada do mundo. Os discursos da imprensa, como todo discurso, dizem respeito a sua própria posição institucional e econômica, e às circunstâncias particulares dos diferentes papéis. É bastante claro que várias características culturais e econômicas da imprensa se combinam para dar uma importância única na (re)produção da ideologia. (FOWLER, 2007, p. 120.) 
Fowler aponta fatores que contribuem para a reprodução da ideologia. $O$ primeiro envolve a escala de publicação e o sistema de venda e de distribuição dos impressos a uma população para a qual leitura de jornal faz parte da rotina diária. $\mathrm{O}$ segundo fator refere-se às circunstâncias econômicas e políticas da indústria jornalística que varia um pouco o seu papel e o ponto de vista sobre aspectos da realidade para mediar perspectivas especiais. Por fim, é principalmente nos tempos de instabilidade ou de crise que as estratégias e alternativas globais, muitas vezes concorrentes, realizam mudanças estruturais.

As mudanças rápidas e profundas da sociedade contemporânea, associadas à globalização são atribuídas às práticas sociais e, concretamente, aos gêneros em circulação na sociedade, posto que são eles que estruturam e que alteram a organização espacial das relações de poder e de dominação, por conseguinte, das atividades sociais. Os gêneros constituídos de um gênero principal e de um subgênero, por exemplo, são os formatos tecnológicos emergentes (websites) que, de forma inovadora, combinam fotografias, imagens e vídeos em sua composição, de modo a projetar um impressionante efeito de sentido ideológico, portanto, o gênero discursivo será utilizado como categoria de análise em nossa pesquisa.

Para van Dijk (1998) é importante analisar a ideologia com base no triângulo conceitual discurso - cognição - sociedade - por várias razões: porque as ideologias são práticas sociais associadas ao uso da linguagem, porque elas pertencem ao campo simbólico do pensamento e das crenças e porque uma vez que associadas com as lutas e conflitos sociais e interesses dos grupos de poder elas possuem um caráter social.

De acordo com a ADC, o trabalho ideológico dos textos está ligado às relações hegemônicas e universalizantes. Sistemas de valores e pressupostos associados pertencem a discursos que, em alguns casos, estão mesmo associados a ideologias. Mas ao analisarmos um texto, não afirmamos que é ideológico apenas com base em algumas evidências textuais. O exame das formas simbólicas baseiam-se em análises das complexas relações entre a linguagem e as relações de sociais de poder. $O$ trabalho ideológico, segundo a $A D C$, deve ser analisado no discurso econômico político para que se possa desvelar como relações hegemônicas são alimentadas, produzidas e legitimadas. 
Buscamos investigar como o trabalho ideológico se realiza nas formas econômicas e políticas factuais da mídia global contemporânea. Analisaremos, precisamente, três modos - a legitimação, a dissimilação e a fragmentação - por meio dos quais a ideologia opera em narrativas multimodais mediadas por meios de comunicação impressos de alto consumo sobrepondo-se e reforçando-se mutuamente.

\subsection{Teoria Sociocognitiva do Contexto}

A Teoria Sociocognitiva do Contexto defendida por van Dijk (2012) é uma perspectiva multidisciplinar desenvolvida no âmbito dos estudos do discurso que busca explicar a interface cognitiva que relaciona as formas discursivas aos seus contextos sociais. Os contextos são definidos como modelos mentais das propriedades de uma situação ou de um evento sociocomunicativo, os quais formam a base da construção das representações e controlam a produção e a compreensão do discurso. O que fundamentalmente explica a natureza das relações entre a sociedade e o discurso é o contexto, motivo pelo qual as pessoas produzem textos diferentes em situações sociais comuns.

Coadunamos a Teoria Sociocognitiva do Contexto à Análise de Discurso Crítica e a Teoria Semiótica Social da Multimodalidade porque, embora estas perspectivas linguísticas baseiem-se na Linguística Sistêmica Funcional (LSF), teoria que vê os contextos sociais como construtos antimentalistas, elas reconhecem a existência da interface cognitiva nas formas sociodiscursivas.

A Teoria Sociocognitiva do Contexto define os contextos como modelos mentais das propriedades de uma situação ou de um evento sociocomunicativo, os quais formam a base da construção das representações e controlam a produção e a compreensão do discurso. O que fundamentalmente explica a natureza das relações entre a sociedade e o discurso é o contexto, motivo pelo qual a pessoas produzem textos diferentes em situações sociais comuns.

Van Dijk (2012) expõe que há propriedades do contexto bastante relevantes no uso do discurso e de semioses. As propriedades mencionadas são dimensões 
globais e locais do contexto, os esquemas de contexto guardados na memória; o eu-mesmo e os tamanhos dos modelos mentais. Situações representadas como globais podem corresponder a microssituações presentes na vida cotidiana, assim como eventos locais podem ser representados como parte de contextos mais amplos, especialmente em momentos de planejamento ou de evocação, quando o uso das capacidades gerais de produção e de compreensão é requerido.

$\mathrm{Na}$ era da digitalização, contextos são modelos que podem influenciar as estruturas do discurso, se ativados de modo relevante e com eficácia por pessoa especializada capaz de representar os eventos sociais em diferentes modos semióticos, usando um modo físico de manipulação. O conhecimento, por conseguinte, é um aspecto essencial para a formação de novos modelos mentais e para atualização dos modelos de contexto.

De acordo com van Dijk (2012, p.127), a estruturação do discurso acontece sob o controle dos modelos. O processamento de uma narrativa jornalística, como parte de um evento sociocomunicativo é direcionado por modelos de contexto. Desde a sua manchete, passando pela linha dedicada ao autor, às etapas do lide, a narrativa é produzida conforme esquemas e exigências contextuais. O processo envolve o conhecimento de informações já publicadas, o modelo de contexto do editor, o modelo de contexto do jornal (ideologia), o conhecimento sobre o gênero, os principais tópicos do modelo de evento, o conhecimento e o interesse do público sobre o evento. A produção pressupõe que a informação mais interessante sobre o que será narrado envolve a aplicação de estratégias cognitivas em sua representação. Isso aponta para a análise das ênfases dadas às ações de um grupo em consonância com as convenções de gênero, com o estilo e o viés ideológico do jornal. Nesse sentido, o autor declara que:

O discurso é produzido e interpretado sob o controle de modelos de contextos. Um dos componentes desses modelos é um dispositivo (...) que controla os modos como o conhecimento (...) é administrado para produzir discursos e interpretações apropriadas. Nessa administração são cruciais certas estratégias que, para a maioria dos discursos, se baseiam na natureza socialmente compartilhada do conhecimento dos interlocutores da mesma comunidade. (VAN DIJK, 2012, p.133.)

É devido à impossibilidade de representar imediatamente tudo o que foi anteriormente processado sobre um assunto que estratégias de atualização dos 
modelos mentais são aplicadas pelos meios de comunicação. Isso é possível porque o processamento do discurso dispõe de um mecanismo central que regula a expressão do conhecimento. O uso eficaz desse mecanismo na administração do conhecimento contextual atualiza os conhecimentos pessoais, específicos, socioculturais e gerais guardados na memória episódica dos participantes. Assim, uma vez que os receptores de mensagens já sabem o que já foi dito pelos meios de comunicação, não é necessário rearticular as informações.

Em se tratando da comunicação midiática, Fairclough (199, p. 36) destaca que os contextos envolvem a natureza do mercado no qual a comunicação opera globalmente, as relações com os Estados-Nação, os aspectos estruturais da comunicação de massa, além das práticas de produção de textos, no âmbito das instituições de mídia (imprensa, rádio e televisão e internet), e as práticas de consumo e de recepção de textos.

A noção de contexto adotada por Fairclough envolve os níveis constitutivos da linguagem (o semântico, o léxico-gramatical e o fonológico/grafológico), os quais são dependentes de um contexto de situação, e de um contexto de cultura. A noção baseia-se no funcionamento das formas linguísticas regulares em registros e em gêneros textuais relacionados ao contexto social. A concepção não antevê a interface cognitiva entre o discurso e a sociedade, porém, como nenhuma teoria dá conta de tudo, o que não é um desacerto, mas uma característica inescapável, a perspectiva sociocognitiva de contexto contribui com sua relevância para esta pesquisa. A análise crítica explanatória de textos (FAIRCLOUGH, 2003), considera sensato proceder aplicar a metodologia da ADC em conjunto com outras formas de análises.

Para Van Dijk (2012) o contexto é a estrutura mental utilizada para representar com relevância uma situação social. O modelo internalizado na memória episódica do participante de uma situação sociocomunicativa é o aspecto que organiza as experiências cotidianas em esquemas úteis à compreensão do discurso e à recuperação de modelos mentais antigos.

Os modelos de contexto, fruto da capacidade humana de representar as situações e eventos sociais, dependem da seleção dos modelos mentais relevantes 
cujas propriedades permitem controlar a produção e a interpretação do discurso. Isso significa que os modelos de contextos são moldados por uma cognição social, por modelos de contexto capazes de definir a visão de mundo e de influenciar os discursos engendrados por grupos ou por indivíduos. A compreensão dos eventos narrados pelos meios de comunicação vai sempre depender da ativação de os modelos de contextos armazenados na memória de longo prazo. Disso resulta a importância de analisarmos os diferentes contextos (globais, institucionais, eventuais) de produção dos textos narrativos ideológicas, pois uma vez armazenados na memória de longo prazo, serão frequentemente ativados para satisfazer às relações de poder.

Van Dijk (2011, p. 154) chama a atenção para a análise do contexto dos textos midiáticos. O que é interessante e útil depende do modelo de contexto do meio de comunicação, do que o editor quer publicar e daquilo que o público está acostumado a consumir. Embora o conhecimento de quem vai acessar a informação e o assunto a ser narrado já exista em larga medida antes que um novo modelo de contexto comece a operar, o conhecimento pode ser transformado. Assim, à medida que um modelo de contexto for sendo executado, o que foi retratado e o que é realizado como novo pelo discurso torna-se parte das ações que condicionam as próximas ações.

Fairclough (2003, p. 84) aduz que as novas narrativas são uma forma violenta de regulação e de controle das ações sociais. De acordo com este autor, as narrativas jornalísticas não são organizadas na ordem lógica e cronológica dos acontecimentos, mas por critérios de relevância ou de interesse. Sobre a série dos eventos complexos que constituem logicamente uma história original, é imposta, portanto, uma ordem que fragmenta o texto. Para Kress e van Leeuwen (1996, 2006), assim como a linguagem, os modos semióticos elaborados por recursos aplicados no momento de sua marcação, são influenciados por motivações e interesses de contextos específicos. Os significados construídos pelos modos que constituem as narrativas visuais são determinados por interesses (modelos de contexto) dos atores sociais. As narrativas desempenhem papéis específicos, mas podem ser processadas como modelos globais socialmente valorizados (KRESS E 
VAN LEEUWEN, 1996, 2006). Assim, os pressupostos das teorias sociais da linguagem convergem plenamente com os da teoria do contexto de van Dijk (2011).

A análise crítica de um texto narrativo distingue a macroestrutura (gênero discursivo) da microestrutura (elementos lexicais, gramaticais, e estilísticos), dando preferência ao gênero. Desse modo, uma reportagem jornalística (como exemplificado no primeiro capítulo do estudo) constitui-se, em termos da sua organização geral, de uma manchete, de uma história, de um evento principal, dos elementos que cobrem o evento da história e de um comentário. A manchete formula o tema geral do texto, mas cada elemento da estrutura esquemática corresponde a um tema mais geral. Características importantes dessa estrutura esquemática são a relevância e a primazia da informação geral, seguida dos detalhamentos da informação. As manchetes expressas pelos tópicos principais e pelas sínteses das narrativas que evidenciam diferenças, divergências e ameaças geralmente tornam-se estereotipadas e preconceituosas. Sendo assim, é interessante analisar, com cautela, as manchetes que tratam de membros dos grupos dominantes e dos grupos minoritários, considerando se elas tendem a enfatizar características negativas destes e positivas daqueles, pois, em geral, as informações positivas são relativas ao nós e as negativas são sobre eles (VAN DIJK 2008, p. 144).

Ainda, a análise da macroestrutura de uma narrativa jornalística é intrínseca aos contextos trazidos ao conhecimento do público leitor. Seu exame envolve a investigação da coerência entre as relações semânticas (causa e consequência, por exemplo) e dos significados subjacentes aos tópicos relacionados a questões econômicas e políticas. A propósito, vimos no primeiro capítulo desse estudo, que a queda da moeda brasileira é representada ideologicamente, posto que atribuída às manifestações populares contra o aumento do combustível e contra a corrupção (Figura: 9 - Desvalorização do real), em vez de a sua causa sistêmica: a crise financeira que a todos afeta. Na realidade, quanto menos conscientes forem as representações sociais, mais o consenso estará interligado aos valores de grupos dominantes contribuindo, desse modo, para a reprodução dos sentidos ideológicos. As microestruturas, por sua vez, são analisadas, mas somente em termos de 
características formais, do estilo jornalístico e da retórica que assegura, ao gênero, uma aura de factualidade.

Vale acrescentar que o diálogo entre as abordagens é fundamentalmente complementar, pois, enquanto Fairclough estabelecia as bases de investigação do discurso, como um espaço de manutenção de poder, Van Dijk estudava a cognição para explicar os mecanismos de processamento do discurso. Por sua vez, Kress investigava como diferentes sociedades valorizam os modos de representação e van Leeuwen, no âmbito da $A C D$, trabalhava a relação de significados entre informações visuais e discursivas e os significados das imagens (WODAK, 2004).

Em virtude do tema da pesquisa e da orientação multidisciplinar, definida pelo triângulo discurso - cognição - sociedade (WODAC, 2003), o contexto torna-se uma categoria relevante às análises semióticas realizadas no capítulo cinco, por ser uma dimensão da prática midiática sem a qual os significados acionados, representados e identificados nas narrativas jornalísticas são analisados de forma limitada. 


\title{
Capítulo 4
}

\section{O CAMINHO TRANSDISCIPLINAR}

\begin{abstract}
A pesquisa qualitativa é um campo interdisciplinar, transdisciplinar e, às vezes, contradisciplinar, que atravessa as humanidades, as ciências sociais $e$ as ciências físicas (...). Tem um foco multipragmático. Seus praticantes são suscetíveis ao valor da abordagem de múltiplos métodos, tendo um compromisso com a perspectiva naturalista e a compreensão interpretativa da experiência humana. Ao mesmo tempo, trata-se de um campo inerentemente político e influenciado por múltiplas lealdades éticas e políticas. (LINCOLN e DENZIN, 2010, p. 390.)
\end{abstract}

Desde a elaboração do projeto desta pesquisa, ao assumimos 0 compromisso de ampliar e de aprofundar o fenômeno semiótico em questão, como forma de contribuir para reflexões atuais e futuras, e de adotar metodologias adequadas para concretização do nosso intento, percebemos o incômodo causado pela crítica, mas dado à importância do tema, que suscitava interesse social, decidimos submetê-lo a exame.

Diante das tensões, das hesitações e das incertezas causadas por investigações dessa natureza, buscamos as orientações de Flick (2004), de Bauer e Gaskell (2005) e de Denzin e Lincoln (2010), segundo os quais a credibilidade da pesquisa qualitativa é assegurada no cenário da produção do conhecimento e na triangulação de saberes e de dados. Essa consciência metodológica nos possibilitou superar visões parciais sobre o objeto de pesquisa e relacionar diferentes abordagens teóricas dentro de um pensamento coerente.

O objetivo desse capítulo é elucidar, de forma sintética, o caminho percorrido para a concretização da pesquisa intitulada Narrativas Midiáticas Multimodais e seus Efeitos Sociais, um entre outros desenvolvidos na área de Linguagem e Sociedade, precisamente, na linha Discursos, Representações Sociais e Textos. 
Como já mencionado, a pesquisa requereu o estudo amplo, progressivo e aprofundado de teorias pertinentes e dialeticamente relacionadas. Assim, com base na teoria Semiótica Social da Multimodalidade (KRESS e VAN LEEUWEN, 2006), na Análise de Discurso Crítica (FAIRCLOUGH, 2003), na teoria Sociocognitiva do Contexto (VAN LEEUWEN, 2012) e na teoria sociocomunicativa da Ideologia (THOMPSON, 2011) nossa pesquisa foi fundamentada.

O trabalho desenvolveu-se com o estudo resiliente de metodologias abertas e sensíveis. Metodologias como a Multimodalidade e a ADC viabilizaram nosso percurso transdisciplinar. A orientação para o detalhamento de categorias semióticas aplicáveis aos dados selecionados, intuitiva e continuadamente no decorrer de dois anos, incluiu o detalhamento do contexto de produção das semioses midiáticas e dos modos da ideologia incorporados aos textos. O quadro a seguir, mostra as bases das categorias analíticas que julgamos apropriadas para responder às questões delineadoras do nosso estudo crítico.

Quadro 15 - Bases das categorias de análise

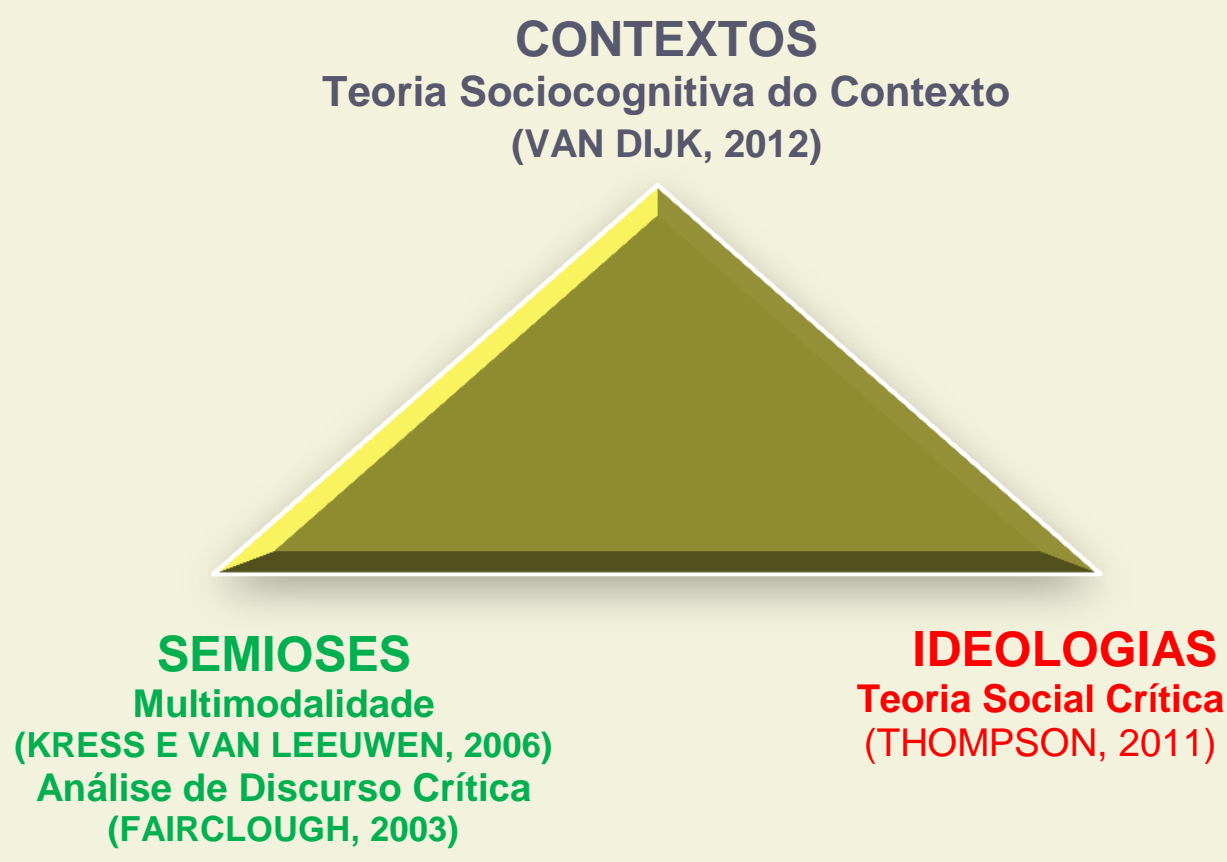

Fonte: Elaborado pela autora. 


\subsection{Tese e questões de pesquisa}

Defendemos a tese de que as narrativas multimodais veiculadas pela mídia contemporânea são um gênero de texto produzido sob o controle de modelos de contextos globais e locais persuasivos, em cujo formato tecnológico os elementos são representados e modalizados de modo a produzir efeitos de sentido sobre as condutas sociais; portanto, não são (re)produções fiéis da realidade como é do senso comum. Para tanto, utilizamos as três seguintes questões:

1. Como as narrativas multimodais difundidas pela mídia global são estrategicamente organizadas para ter efeitos sociais?

2. De que modo os participantes das estruturas narrativas midiáticas são representados ideologicamente?

3. Como são modalizadas as narrativas midiáticas multimodais manipuladas pela mídia impressa?

Do interesse em analisar os modos de produção das narrativas multimodais mediadas pela mídia e os efeitos que estas formas simbólicas projetam sobre a vida em sociedade, abordamos inicialmente os contextos globais e os contextos locais que, indireta e diretamente, controlam a produção e a difusão de essas formas, por entendermos estão intrinsecamente relacionados. Os contextos dos eventos sociais representados pelo gênero também são investigados em sua conjuntura, porque estes seguramente (re)constróem a realidade imediata com sentidos particulares.

\subsection{Amostra representativa de dados}

Para analisarmos os modos de construção das narrativas multimodais difundidas pela mídia contemporânea, geramos, antes, uma amostra representativa de dados impressos no decorrer de dois anos ininterruptos. Foram escolhidos textos multimodais da mídia impressa que retratam momentos socioculturais significativos bem como situações problemáticas e críticas na vida dos indivíduos (BAUER E GASKELL, 2005). 
A amostra foi composta por intermédio do uso de aparelhos móveis digitais e de recursos tecnológicos - internet, câmaras fotográficas, i-phones, iriscanmouses e scanners (BALDRY E THIBAULT, 2006). A amostra compõe-se de textos de primeira página de jornais de circulação nacional e internacional e de revistas de notícias de alcance global e de alto consumo.

Os modos da escrita e do visual, nos textos coletados, interagem de forma equilibrada para representar os acontecimentos cobertos pela grande mídia. Vários textos da amostra foram utilizados nos primeiros capítulos da tese com o intuito de demonstrar a validade de argumentos apresentados, mas quatro narrativas midiáticas multimodais extraídas dessa amostra são efetivamente analisadas.

\subsection{Dados de análise}

Quatro textos narrativos multimodais de mídia constituem os dados de análise da pesquisa propriamente dita. Três desses textos foram publicados pela revista Veja (um dos três textos foi veiculado em página interna de edição especial da Veja) e o outro texto foi publicado pela revista inglesa The Economist. Os textos da edição especial da Veja - um veiculado na capa da revista e o outro em página interna - têm como contexto o aniversário de 50 anos da Capital Federal. O outro texto publicado na capa da revista brasileira tem como contexto às manifestações populares desencadeados no Brasil em meados de 2013. E o texto publicado na capa da revista The Economist, de $1^{\circ}$ de março de 2014, tem como contexto a democracia. A Veja foi escolhida por ser revista nacional alinhada às ideias econômicas neoliberalistas e por ser a quarta revista com maior tiragem no mundo. A revista inglesa foi escolhida por ser alcance global, ter um público alvo qualificado e influente e estimular a privatização, a desregulamentação e a liberalização. Eis os dados: 
Figura $35-50$ anos de Brasília Revista Veja, novembro de 2009 Edição especial

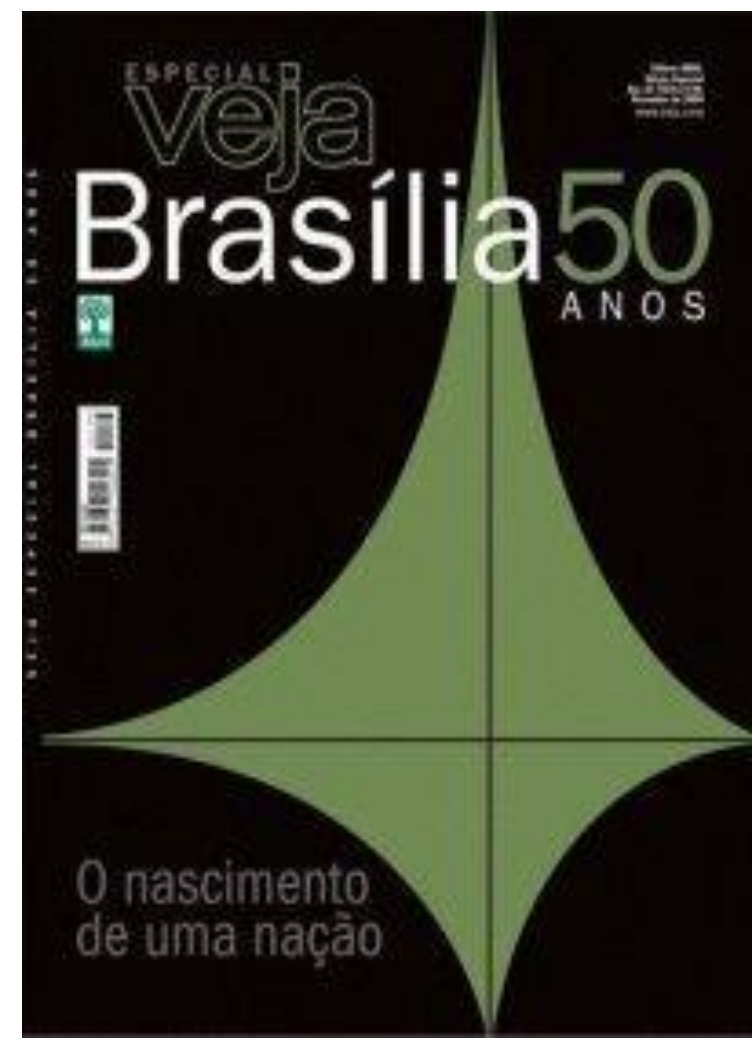

Fonte: Abril, ano 42, n. 2.138.
Figura 36 - 50 anos de Brasília Revista Veja, novembro de 2009 Edição especial

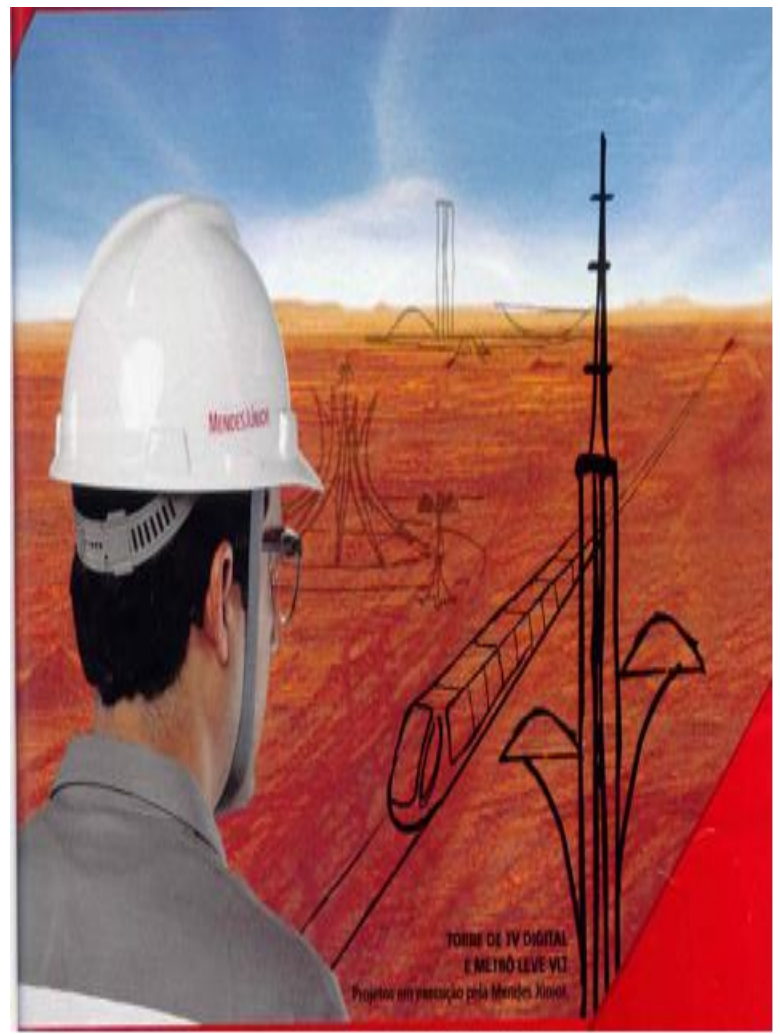

Fonte: Abril, ano 42, n. 2.138. 
Figura 37 - Manifestação popular Revista Veja, 3 de julho de 2013

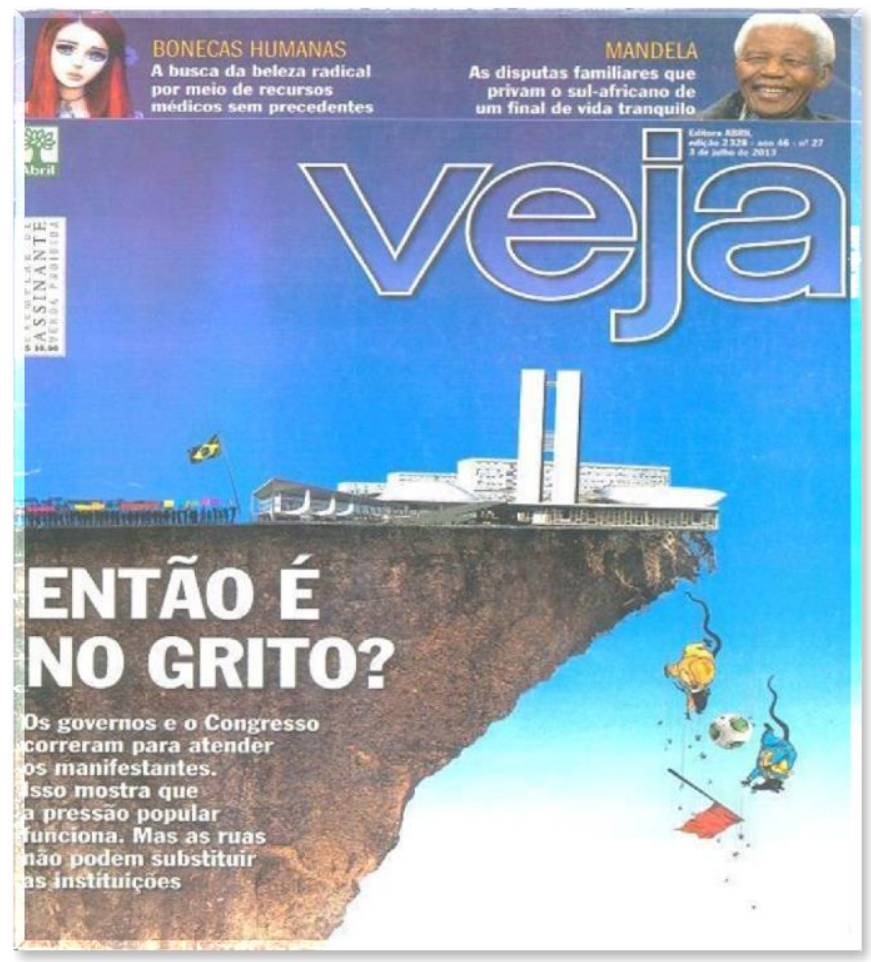

Fonte: Abril, edição 2.328, ano 46, n. 27.

Figura 38 - Democracia

Revista The Economist, 1 a 7 de maio de 2014

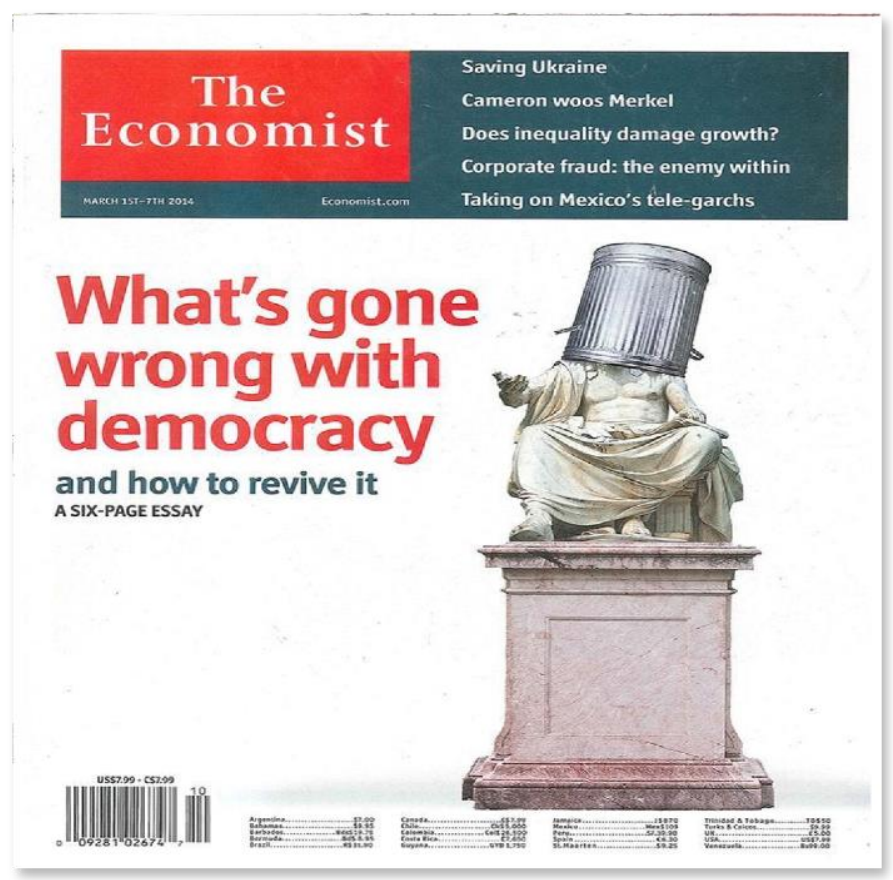

Fonte: The Economist, vol. 410, n. 8.876 . 
É importante mencionar que os modos semióticos (a escrita e o visual) que constituem os dados expostos são analisados conjuntamente. Embora seja útil contrastar os modos dos textos, foi difícil separá-los (BAUER E GASKELL, 2005), porque eles se integram no todo da composição multimodal. Os modos semióticos são heterogêneos, mas foram trabalhados conjuntamente. Sendo assim, a chave para análises consistentes residiu no conhecimento sobre os recursos dos modos e na triangulação dos dados analisados.

\subsection{Metodologias analíticas}

A Multimodalidade e a Análise de Discurso Crítica (ADC) são as metodologias qualitativas adotadas na pesquisa, por serem abertas e sensíveis a perspectivas teóricas novas, como já mencionado. Nossa perspectiva teórica multidisciplinar encontra no campo da transdisciplinariedade o apoio metodológico para a compreensão da complexa relação existente entre os contextos e os textos, para a análise semiótica crítica dos dados coletados bem como para o desvelamento dos efeitos potenciais de sentido das semioses em cujas formas os modos da ideologia são incorporados.

As metodologias qualitativas tem oferecido um caminho útil por meio do qual os analistas, sob uma perspectiva antimentalista de contexto, investigam os contextos cultural e imediato das formas de ação, de representação e de identificação cujos significados discursivos investigam com propriedade. Mas a natureza qualitativa de ambos os campos transdisciplinares nos permitem introduzir uma perspectiva mentalista de contexto fundamental ao nosso empreendimento crítico (VAN DIJK, 2011). Acreditamos que o acesso aos contextos de produção das formas simbólicas em toda a sua complexidade; procedimento analítico que vai além do esquadrinhamento do contexto cultural e imediato dos eventos sociais narrados pela mídia, é essencial à explanação dos significados subjacentes às formas semióticas de (re)produção das estruturas sociais. 


\subsubsection{A Multimodalidade}

A Multimodalidade possui métodos de descrição e métodos de análise dos modos semióticos, por meio dos quais é possível analisar o amplo repertório de recursos que as pessoas usam para se comunicar, para representar ações e eventos sociais e para significar o mundo real. Assim como o modo discursivo é analisado, outros modos semióticos também podem ser investigados porque realizam o trabalho comunicativo plenamente.

Considerando o caráter arbitrário da relação entre a linguagem e o contexto, a Multimodalidade mostra o que as pessoas fazem com os diferentes recursos semióticos (sistemas de significados) em um todo composicional significativo do mundo social dinâmico. As imagens, as fotografias e vários outros aspectos do mundo - a luz, a escuridão, a chuva, o sol, as árvores e os animais - são signos que, combinados, podem criam inventários de seus significados.

A análise multimodal vê os signos e os modos semióticos resultantes da complexa interação das origens fisiológicas, emocionais, culturais e sociais dos seus produtores como sistemas fluidos e dinâmicos que estão relacionados aos seus contextos de uso. O uso de um recurso semiótico em uma narrativa multimodal em vez de outro, é, em parte, determinado pelo contexto que o conecta ao contexto de produção do texto (JEWITT, 2009, p. 31).

As relações entre os textos e as imagens ainda não estão completamente estabelecidas do ponto de vista teórico, mas as análises de categorias sistematizadas pela Multimodalidade (MACHIN e VAN LEEUWEN, 2007), (KRESS E VAN LEEUWEN, 2006) nos permitem demonstrar as relações entre os modos semióticos e os significados compostos no todo multimodal.

\subsubsection{Análise de Discurso Crítica}

Metodologicamente, a Análise de Discurso Crítica (ADC) trabalha de forma transdisciplinar com outras disciplinas e com as teorias sociais preocupadas os processos que alteram a vida social. O seu objetivo maior é analisar os modos como 
o discurso e as semioses contribuem para as mudanças sociais aceleradas na sociedade contemporânea.

O diálogo da Análise de Discurso Crítica (ADC) com a Teoria Sociocognitiva do Contexto (VAN DIJK, 2012) e com a Teoria Social da Ideologia (THOMPSON, 2011) possibilita investigarmos os modelos de contextos que influenciam a produção das formas, como categoria de análise, bem como interpretarmos os modos da ideologia (a legitimação, a dissimilação e a fragmentação) incorporados nas formas simbólicas da mídia impressa contemporânea.

Aplicamos o método de análise textualmente orientado da ADC para perscrutar os significados das formas discursivas e semióticas, o qual envolve os seguintes procedimentos: a identificação dos contextos (globais, locais e eventuais) segundo a visão sociocognitiva de contexto (VAN DIJK, 20012) - o que envolve a investigação das estruturas e das práticas que mantêm o problema social; a explanação dos modos de construção das formas de ação, de representação e de identificação veiculadas pela mídia; e a interpretação dos possíveis efeitos sociais causados pela incorporação dos modos da ideologia nas narrativas simbólicas.

\subsection{Categorias de análise}

Para demonstrarmos a validade da nossa proposição utilizamos as seguintes categorias de análise: o contexto, segundo a perspectiva sociocognitiva do contexto (VAN DIJK, 2012), o gênero global, a representação narrativa e a modalidade conforme sistematizadas pela Teoria Semiótica Social da Multimodalidade; o gênero discursivo, como categoria de análise proposta pela ADC e os modos da ideologia (legitimação, dissimulação e fragmentação) de acordo como a abordagem crítica de Thompson (2011). O quadro, a seguir, reúne as categorias aplicadas nos dados. 
Quadro 16 - Categorias aplicadas às narrativas midiáticas multimodais

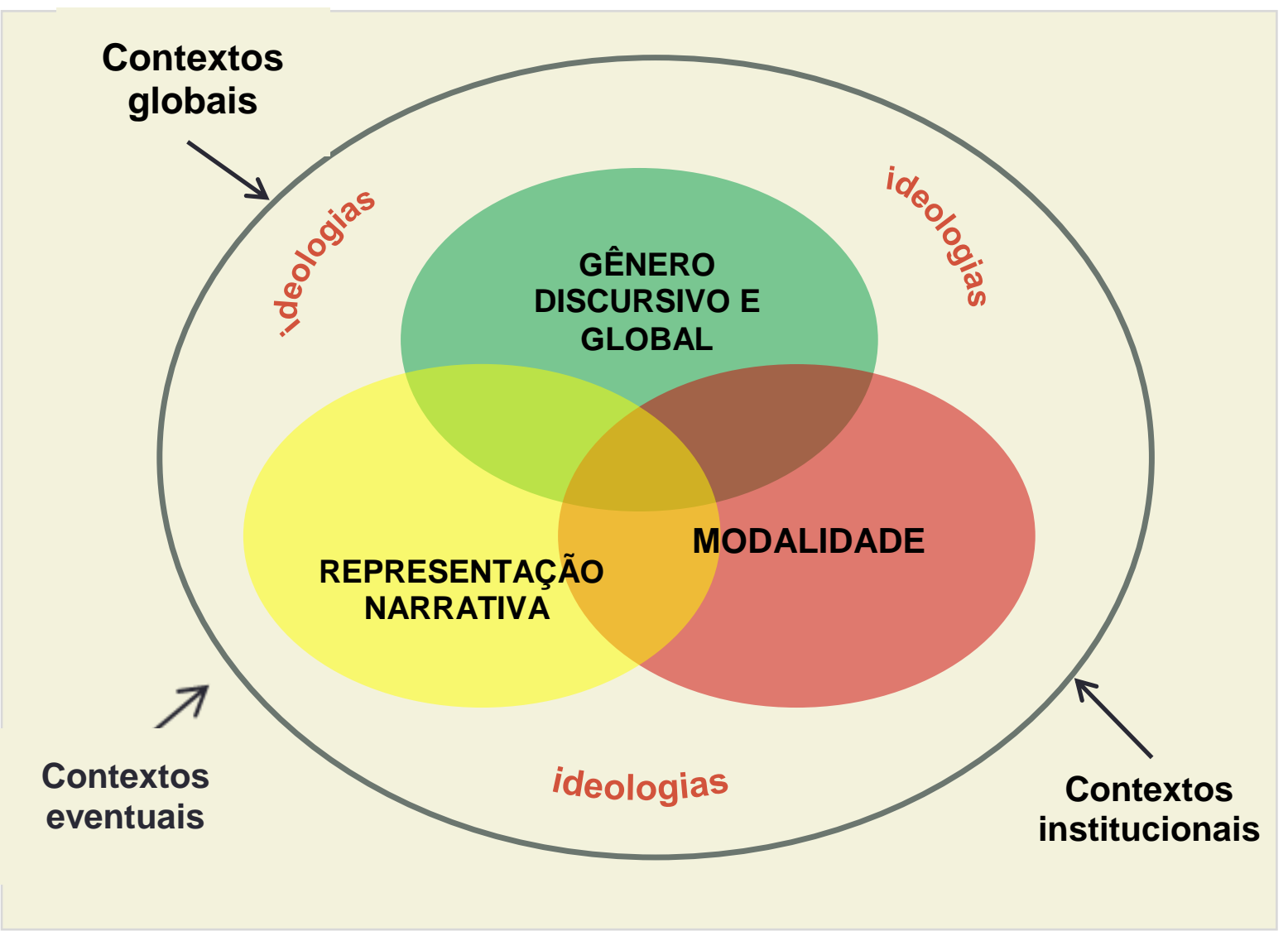

Fonte: Elaborado pela autora ${ }^{26}$.

A escolha da categoria gênero global (MACHIN e VAN LEEUWEN, 2007) e da categoria gênero discursivo (FAIRCLOUGH, 2003) deve-se à importância social da atividade comunicativa, do uso das novas tecnologias pela mídia de massa e do propósito de transparecer os modos como as formas de (inter) ação e de interação da mídia mais valorizadas são estrategicamente organizadas. $\mathrm{O}$ esquadrinhamento dos modos de organização das narrativas midiáticas multimodais deve contribuir para a consciência de que elas são influenciadas por estruturas contextuais, por práticas e por eventos sociais das quais elas são elementos relevantes.

A categoria representação narrativa é selecionada à análise dos dados porque permite transparecer os processos que constituem as estruturas semióticas com base nos quais os participantes e as circunstâncias são representados. A aferição dos modos como são representados os participantes principais e como

\footnotetext{
${ }^{26}$ Quadro elaborado com base nas teorias e nas categorias de análise.
} 
outros elementos das estruturas multimodais são relacionados a estes deve revelar as estratégias sociais e cognitivas incorporadas aos textos para a focalização de pontos de vista particulares.

A preferência pela modalidade, categoria de análise estilística dos textos, deve-se a razões éticas e práticas. A análise dos marcadores de modalidade usados gênero capital da nova mídia torna possível perscrutar se os significados articulados nas formas de (inter)ação que representam os eventos sociais correspondem à verdade dos fatos e dos acontecimentos do mundo social ou se refletem ideologias que legitimam ou dissimulam relações de poder e de dominação.

Em suma, a análise semiótica crítica das narrativas midiáticas multimodais inclui a investigação das seguintes dimensões: explanação dos contextos de produção das formas, a análise das categorias mencionadas e a análise dos modos da ideologia operacionalizados nas formas de (inter)ação, de representação e de estilo da nova mídia. Em todos os dados, sem exceção, essas dimensões categóricas são aplicadas com a finalidade de dar respostas aos questionamentos e, portanto, de defender a tese de que as narrativas multimodais de alto consumo da impressa contemporânea não são (re)produções fiéis da realidade como é do senso comum, mas um gênero de texto produzido sob o controle de modelos de contextos de produção altamente persuasivos, em cujo formato tecnológico os elementos são representados e modalizados de modo a produzir efeitos de sentido sobre as condutas sociais. As análises são efetivamente realizadas no próximo capítulo. 


\section{Capítulo 5}

\section{ANÁLISES SEMIÓTICAS CRÍTICAS DE NARRATIVAS MULTIMODAIS DA MÍDIA IMPRESSA

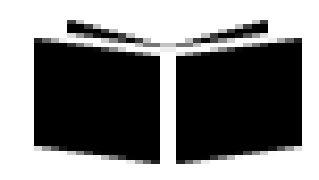

Para defender a tese de que narrativas midiáticas multimodais são um gênero de texto produzido sob o controle de modelos de contextos, em cujo formato tecnológico os elementos são representados e modalizados para ter efeitos de sentido sobre as condutas sociais, este capítulo analisa com criticidade quatro narrativas multimodais veiculadas nos principais suportes (capas) de revistas de alcance global e de alto consumo - a revista brasileira Veja e a revista inglesa The Economist - à luz de categorias sistematizadas por perspectivas distintas, mas dialeticamente relacionadas.

Para responder às questões delineadoras da pesquisa são analisados, primeiramente, os contextos globais e locais (VAN DIJK, 2011) que controlam direta e indiretamente a produção e a distribuição dos textos midiáticos impressos e onlines, bem como os contextos dos eventos materializados nos textos (FAIRCLOUGH, 2003, 2006). Desse modo, é possível clarificar as conjunturas econômicas-políticas que mantêm os problemas sociais, mediante o uso da prática sociodiscursiva da mídia contemporânea. A seguir, são analisados os modos de significação das quase narrativas midiáticas multimodais (THOMPSON, 2011). Assim, os modos de organização dos textos são explanados mediante a análise das categorias gênero global (MACHIN e VAN LEEUWEN, 2007) e gênero discursivo (FAIRCLOUGH, 2003). Os modos de representação dos participantes das estruturas multimodais são analisados com base nos processos narrativos que as constituem (KRESS e VAN LEEUWEN, 2006) e os modos como os eventos são identificados como verdades (VAN LEEUWEN, 2005) são investigados por meio do uso de marcadores de modalidade. Por fim, são criticamente analisados os modos da ideologia estrategicamente operacionalizados nas formas de ação, de representação e de identificação da mídia contemporânea e os efeitos, de curto e de longo prazo, (MACQUAIL, 2013), que eles produzem sobre a vida em sociedade. 


\subsection{Textos A1 E A2}

Contextualização

Os textos multimodais adiante foram veiculados pela edição especial da revista $\operatorname{Veja}^{27}$ de outubro de 2009. O primeiro texto teve sua publicação na capa (suporte) da revista e o segundo em uma página interna da revista. Ambos têm como contexto social o aniversário de 50 Anos de Brasília, Capital Federal, mas cada um dos textos foi planejado, produzido e distribuído para alcançar um resultado específico.

Figura 39 - 50 anos de Brasília Revista Veja 10/2009

Edição especial

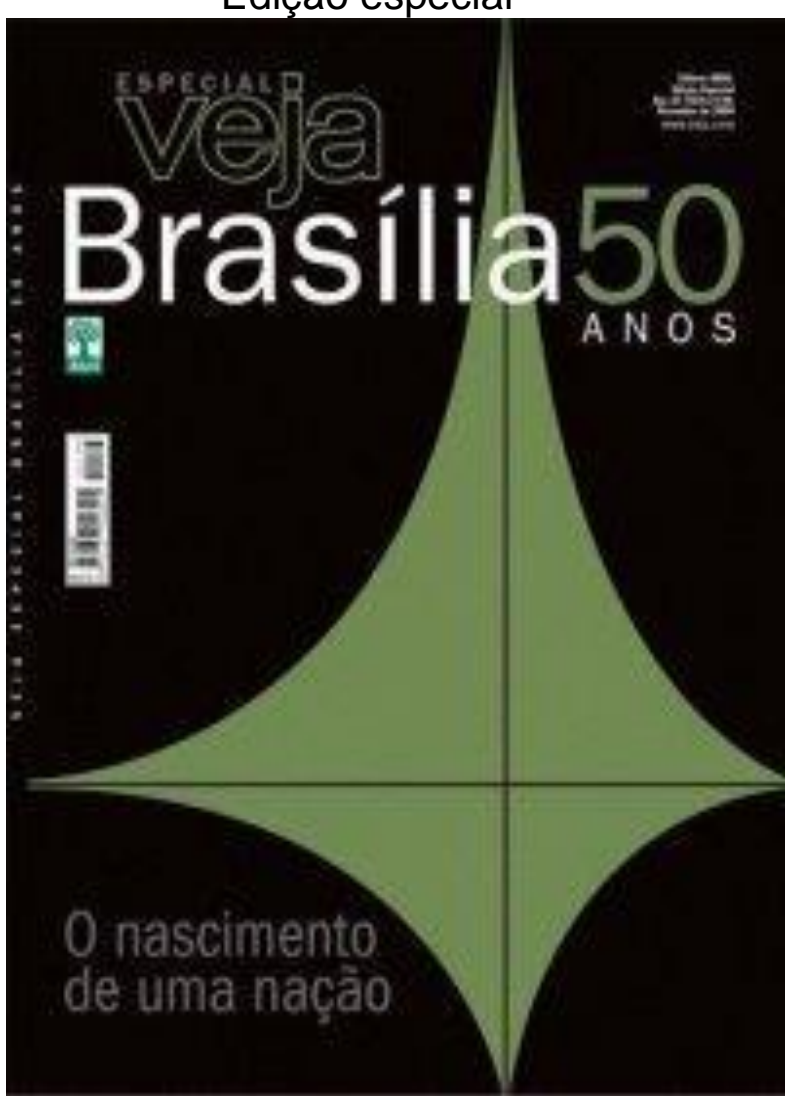

Fonte: Abril, ano 42, n. 2.138
Figura 40 - 50 anos de Brasília Revista Veja 10/2009

Edição especial

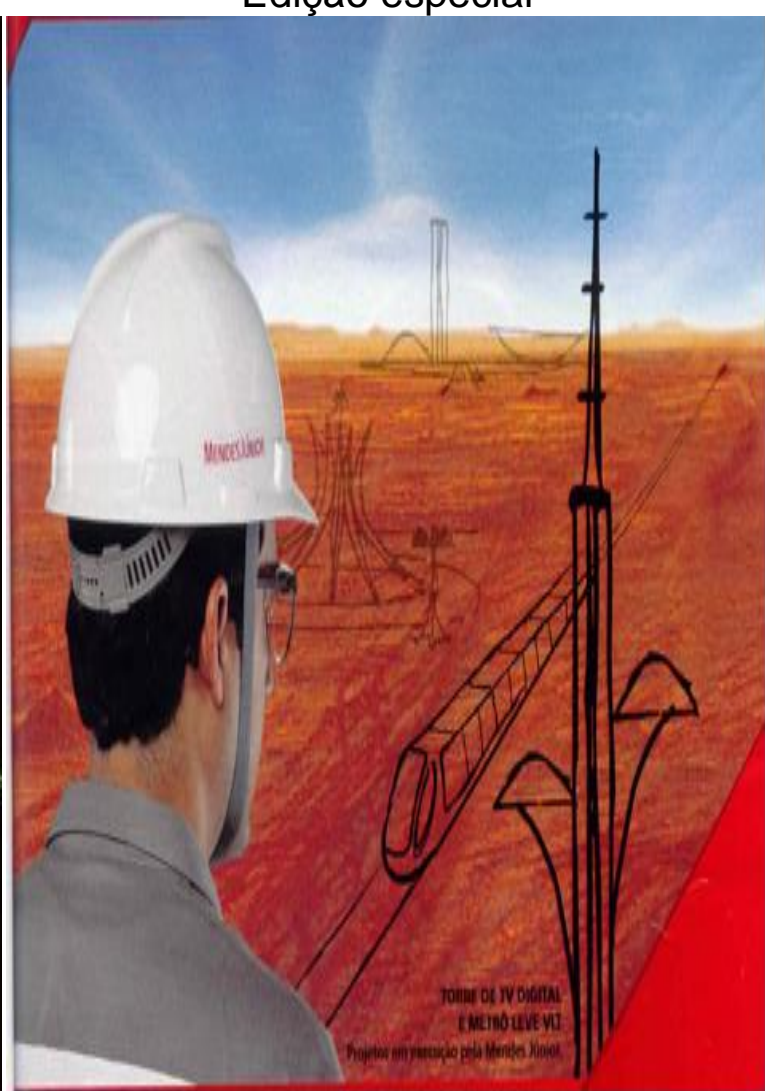

Fonte: Abril, ano 42, n. 2.138.

\footnotetext{
${ }^{27} \mathrm{~A}$ Veja, a quarta revista de notícias mais consumida no mundo, tem uma tiragem semanal superior a um milhão de exemplares.
} 


\subsubsection{Contextos global e local}

Com base na noção de contexto global (Van Dijk, 2011) consideramos que a globalização e o Estado-Nação são os modelos de nível macro que controlam a produção das formas narrativas focalizadas. No contexto da globalização, o neoliberalismo prospera, as ideologias nacionalistas explodem e a sociedade passa a ser governada por regras e por preceitos do sistema capitalista. Embora o Estado-Nação do Brasil seja uma organização sociopolítica estável, nas condições da globalização, ele parece dissolver-se em espaços de interação social (CASTELLS, 2009).

O crescente desafio à soberania dos Estados-Nação em todo o mundo parece advir da sua incapacidade de navegar nas redes globais de comunicação e de interação. A existência desse desafio levou os Estados-Nação a criar uma série de respostas estratégicas com base nas relações de poder existentes nas instituições políticas. Os Estados-Nação em desenvolvimento, como o Brasil, buscam se fortalecer por meio da flexibilização de seus procedimentos de governança e do uso da mídia nacional, que lhe serve como aparato para a divulgação das suas mensagens estratégicas. Analisamos que formas de organização e de gestão das atividades governamentais como essas (Figuras 39 e 40) são tentativas e esforços que buscam reestabelecer o poder dos Estados-Nação e fortalecer o mercado globalizado, respectivamente. Mas elas inevitavelmente refletem a crise e o comprometimento da capacidade instrumental dos Estados-Nação causados pela globalização.

De forma mais precisa, a representação (Figura 39) do evento cultural mediada pela revista Veja (Figura 39) é uma tentativa de reconstrução do poder do Estado Brasileiro a um nível mais elevado, por meio de princípios de legitimação, nível este que viabiliza o controle dos fluxos globais de riqueza, de informação e de poder. Nesse sentido, a mídia nacional age para legitimar o Poder Executivo do Estado-Nação. O que a forma simbólica assegura, a exemplo de outras formas de gestão das questões de ordem política, ambiental e de segurança, é a influência do Estado no atual cenário da globalização.

Recontextualizado por práticas de outros campos de interação, nesse caso, pela prática empresarial, a representação do evento de domínio público (Figura 40), 
pela instituição midiática organiza-se como um gênero de governança que, a exemplo dos anúncios publicitários, serve para promover a Mendes Júnior, uma Empresa Brasileira capaz de reproduzir em larga escala as relações estruturantes do novo capitalismo.

As formas simbólicas veiculadas pela revista brasileira, aqui entendidas como modelos de contexto local (institucional), são fruto do aperfeiçoamento de processos convergentes de produção de mídia - meios impressos e on-line. Ambas possuem alto grau de criatividade, de seletividade e de julgamento, porque nelas estão implementadas condições como: capital, regras, convenções, esquemas, interesses políticos e objetivos econômicos. Ambos os textos midiáticos, portanto, fornecem critérios e referências para a vida social e, na medida em que os seus significados estendem-se para além do consumo do público leitor, a experiência social é moldada, de maneira que aos indivíduos comuns é assegurada a reprodução de um senso para o qual elas foram intencionalmente planejadas.

\subsubsection{Análise contextual do evento social}

Sonhada por dois séculos, a criação de Brasília ${ }^{28}$, inaugurada no dia 21 de abril de 1960, começou a consolidar-se, quando o então Presidente Floriano Peixoto determinou que uma comissão de cientistas explorasse o Planalto Central e demarcasse a área que seria destinada ao Distrito Federal. A Comissão Exploradora do Planalto Central, composta por 21 pessoas e chefiada pelo astrônomo e geógrafo belga Louis Ferdinand Cruls - conhecida como Missão Cruls -, demarcou uma área de $14.400 \mathrm{Km}^{2}$, considerada adequada para a futura capital, que ficou conhecida como "Quadrilátero Cruls". A equipe de Cruls era composta por pesquisadores, geólogos, geógrafos, botânicos, naturalistas, engenheiros e médicos, entre outros, e realizou estudos científicos até então inéditos na região, mapeando aspectos climáticos e topográficos, além de estudar a fauna, a flora, os cursos de rios e modo de vida dos habitantes. Os registros históricos do arquivo público nacional ${ }^{29}$ mostram

\footnotetext{
28 Informações extraídas da página do Senado Federal. Disponível em: <http://www.senado.gov.br/noticias/especiais/brasilia50anos/not02.asp>. Acesso em: 10 fev. 2014.

${ }^{29}$ As fotos e imagens do arquivo público nacional foram extraídas da Veja, edição especial, n. 2.138.
} 
o quadrilátero demarcado na região de Goiás que indicava as distâncias entre as capitais do Brasil e, onde seria construída a Capital denominada Vera Cruz.

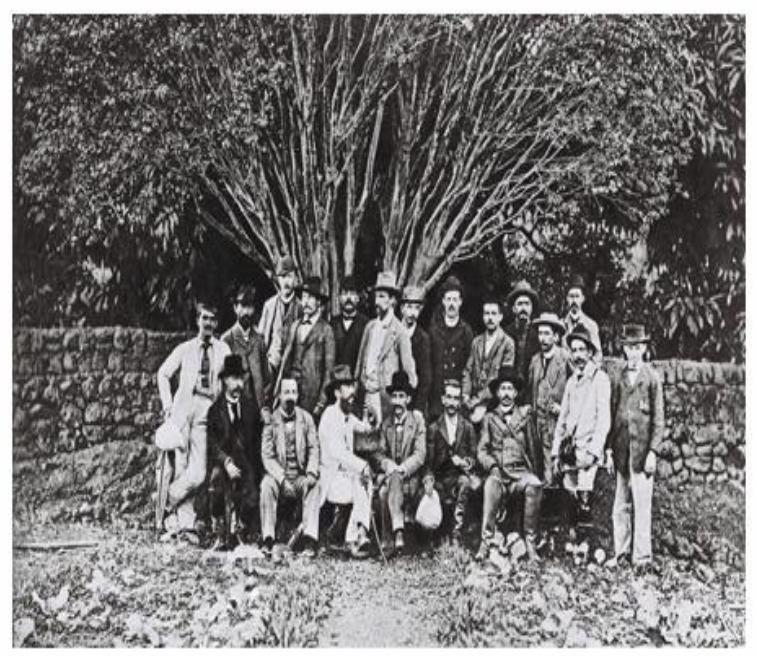

Fonte: Foto do arquivo público nacional.

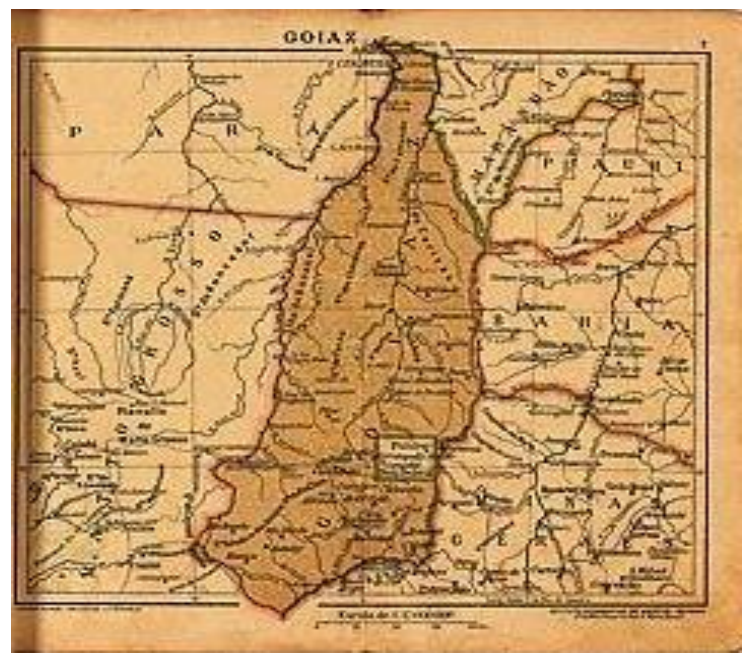

Fonte: Mapa do arquivo público nacional.

Nomeado pelo Presidente Café Filho, o Marechal José Pessoa liderou a Comissão de Localização da Nova Capital, na trilha aberta pela Missão Cruls, onde ergueu uma cruz de madeira no ponto mais alto do cerrado. O planejamento incluía rede de esgoto, ferrovias, rodovias para a construção da nova capital, mas o marechal, posteriormente, renunciou à comissão porque a venda de lotes não poderia ser realizada sem a conclusão e a aprovação do projeto de planejamento.

Figura 43 - Missão José Pessoa (1954)

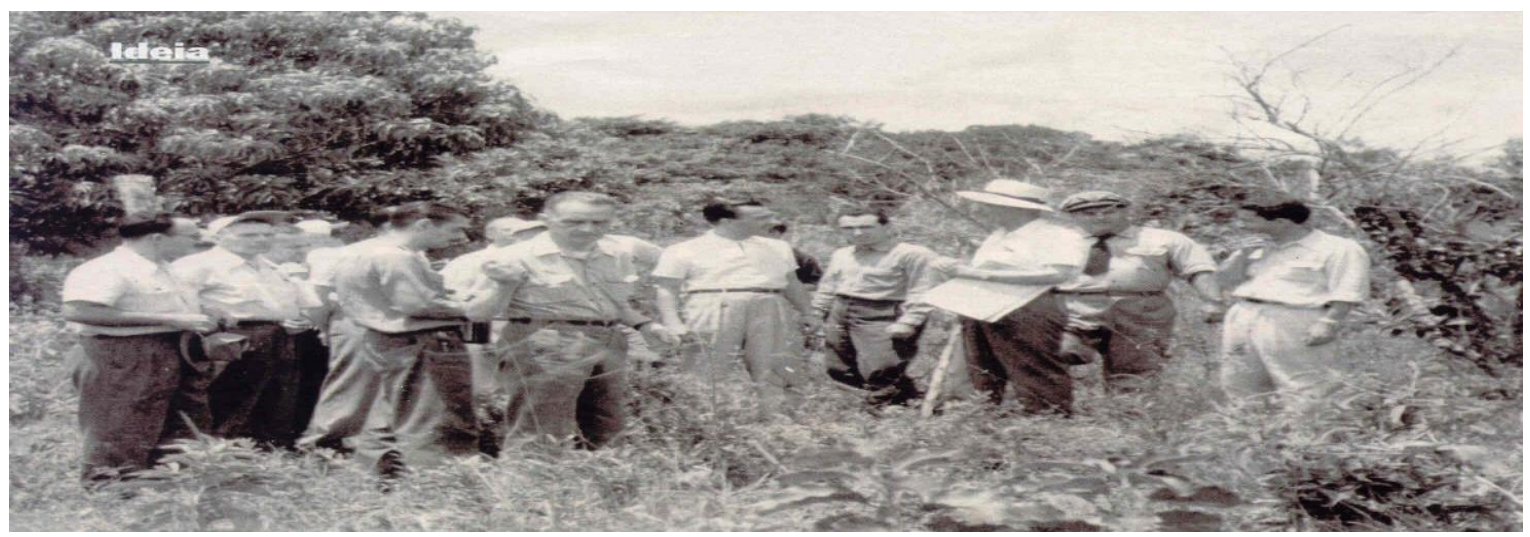

Fonte: Foto do arquivo público nacional. 
Cerca de quarenta anos depois, o Presidente Juscelino Kubitschek assume o compromisso de iniciar o plano de construção da nova capital do Brasil com base no esboço que já existia antes mesmo de os arquitetos Lúcio Costa e Niemeyer elaborarem o projeto urbanístico e os monumentos de Brasília.

Figura 44 - Esboço de Vera Cruz

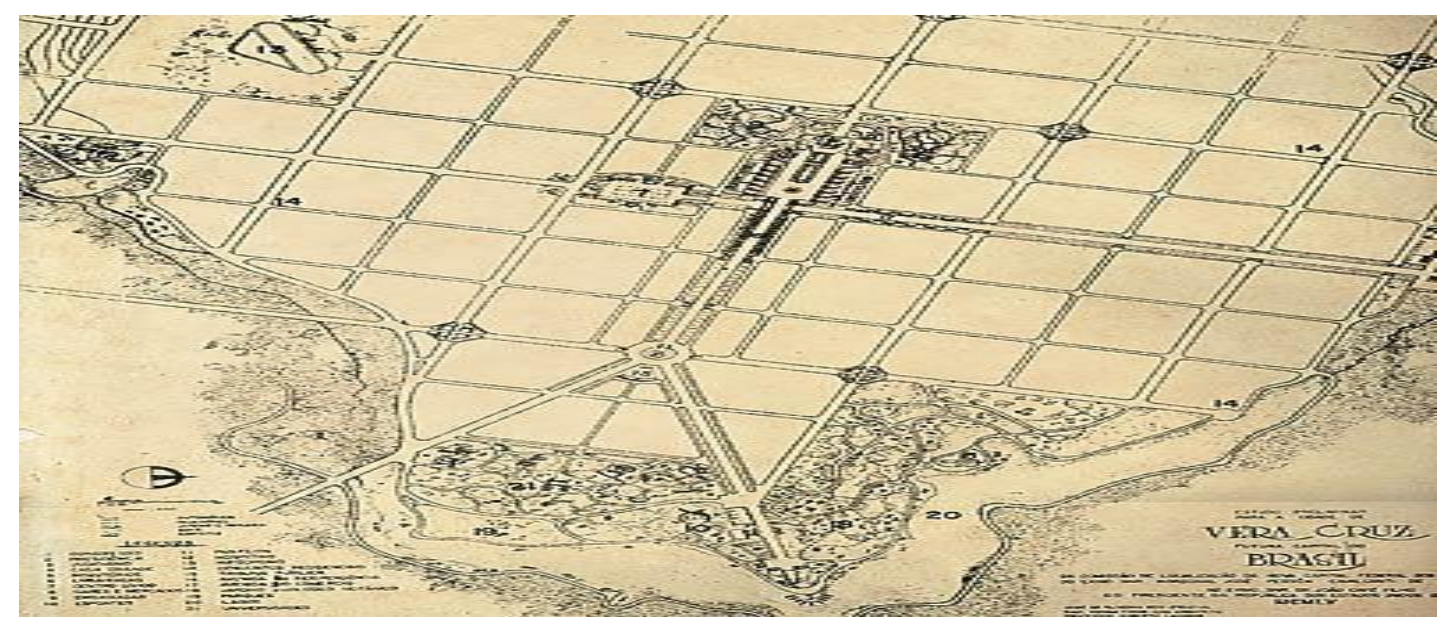

Fonte: <http://terradeencantosbrasil>.

Sua construção começou em 1956, sendo Lúcio Costa seu urbanista e Oscar Niemeyer o principal arquiteto. Três anos e dez meses mais tarde, em 21 de abril de 1960, Brasília transformou-se oficialmente na Capital Federal do Brasil.

Figura 45 - Maquete de Brasília, 22/11/1958 30

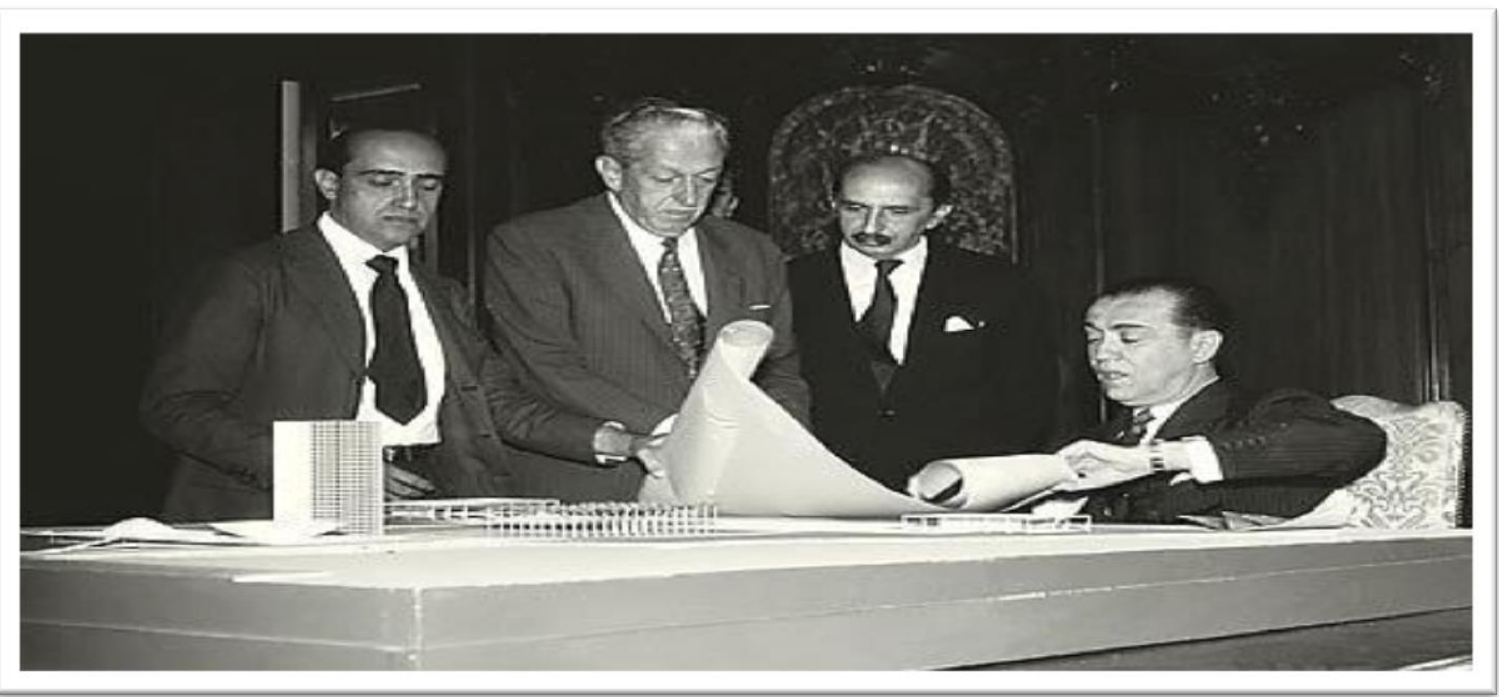

Fonte: Foto do arquivo público nacional.

${ }^{30}$ Da esquerda para a direita: Oscar Niemeyer, Israel Pinheiro, Lúcio Costa e Juscelino Kubitschek. 
A construção de Brasília foi ganhando corpo em diversos momentos históricos, culminando com sua inauguração, pelo Presidente Juscelino Kubitschek, até ser tombada pela Organização das Nações Unidas para a Educação, a Ciência e a Cultura (Unesco) como patrimônio histórico e cultural da humanidade, em 1987. Também é interessante observar as semelhanças existentes entre a configuração geográfica da cidade de Brasília (Figura 46), o nome da Missão (Figura 41) que demarcou a área, o esboço original para o Plano Urbanístico (Figura 44), e o design do texto narrativo publicado pela Veja (Figura 47).

Figura 46 - Plano urbanístico de Brasília-DF

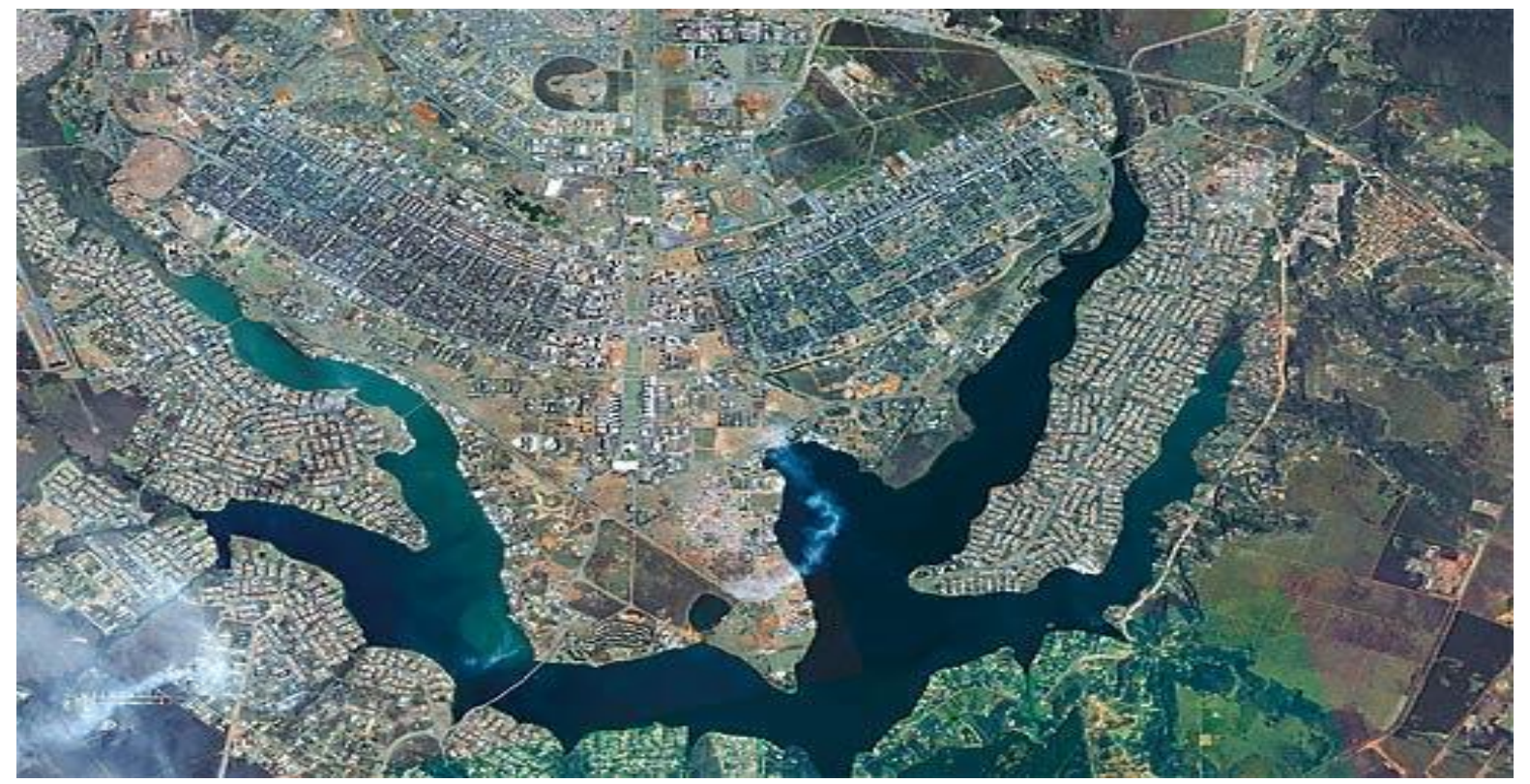

Fonte: <http://veja.abril.com.br/especiais/brasilia/primeira-vez-mapa-p-020>.

Brasília, que hoje tem mais dois milhões e meio de habitantes, é conhecida mundialmente por ter aplicado os princípios estabelecidos pela carta de Atenas de 1933 e ter concretizado o pensamento urbanístico dos anos 50. Brasília foi declarada Patrimônio Histórico da Humanidade pela UNESCO em 1987, sendo a única.

Como os formatos tecnológicos de representação do evento cultural (Figuras 39 e 40) são capazes de atravessar redes particulares de comunicação em diferentes escala, eles, certamente, contribuem para manter a influência do EstadoNação, mas, também, para aperfeiçoar os processos reais da globalização. 
5.1.2.1 Análise do Texto A1

Figura 47- 50 anos de Brasília

Revista Veja 10/2009, Edição Especial.

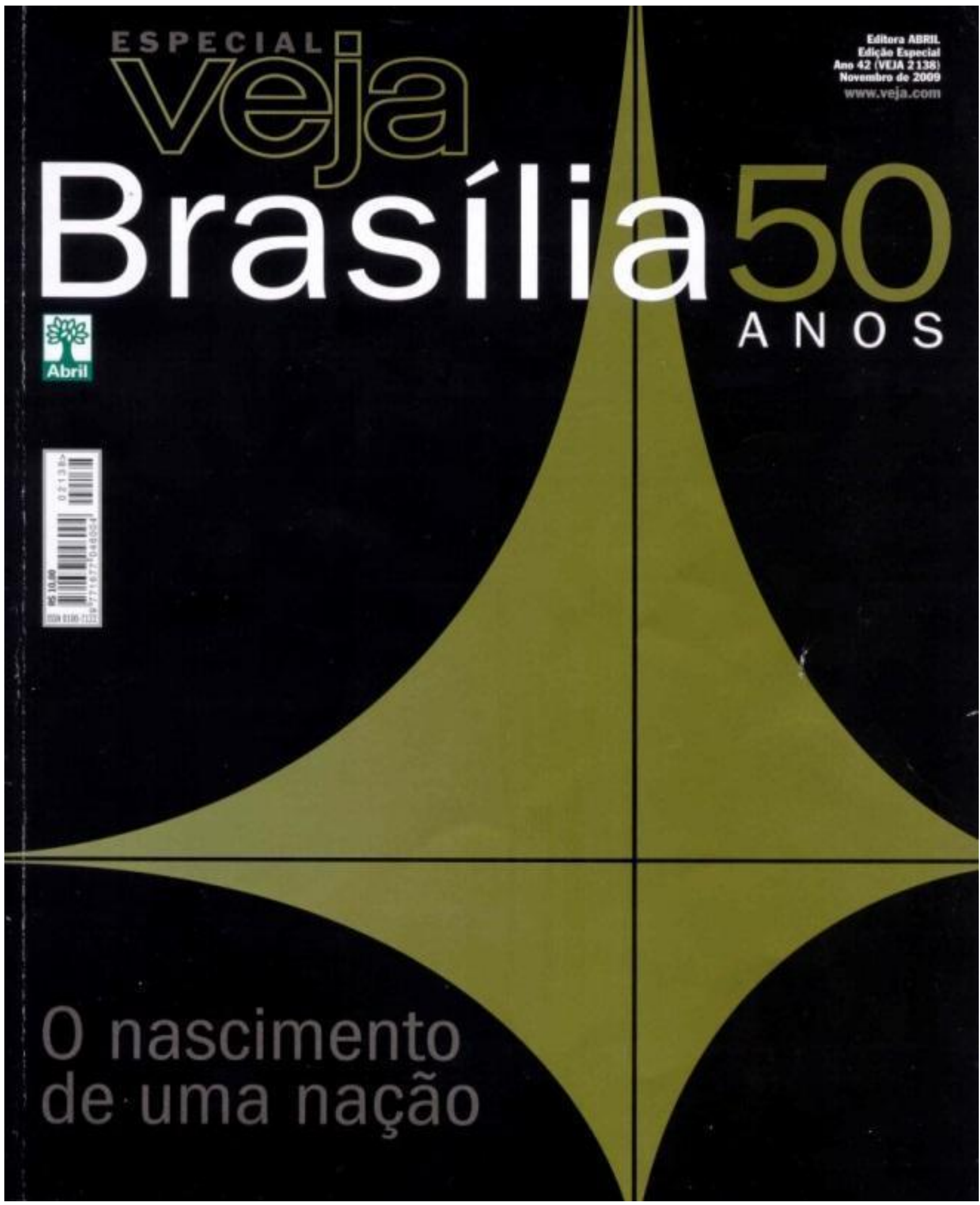

Fonte: Abril, ano 42, n. 2.138, capa. 


\subsection{Gênero discursivo e gênero global}

A representação semiótica (MACHIN e VAN LEEUWEN, 2007) das colunas do Palácio do Planalto em Brasília, símbolo do Patrimônio da Humanidade pode ser reconhecida por seu layout. Nesta forma de (inter)ação, o layout parece ser o mesmo, mas ele incorpora recursos semióticos que acrescentam ao gênero global um conhecimento sócio-histórico dignificante, de modo que o presente é legitimado. Composta por recursos dos modos da escrita e, principalmente, do visual, a narrativa midiática tem um formato tecnológico mais ou menos abstrato que transcende as redes de comunicação em escala global. É um gênero global que acomoda conteúdo simbólico com potencial para unir os indivíduos em uma identidade única.

A narrativa publicada pela revista Veja é discursivamente organizada no eixo horizontal e visualmente no eixo horizontal e vertical. As informações do modo escrito aparecem posicionadas à esquerda da página, como um dado conhecido. No topo da revista (posição ideal), a mensagem é de enaltecimento à Capital Federal, Brasília 50 anos, valor que, em princípio, é inegociável. A informação discursiva que remete ao evento sociocultural aparece logo abaixo, em posição do dado real $\boldsymbol{O}$ nascimento de uma nação. Por serem essas formas genéricas e fragmentadas, o evento pode ser recontextualizado, porém, sem muita variação por ser um gênero global.

No que diz respeito ao modo visual, as colunas verdes do Palácio do Planalto chamam a atenção devido ao seu tamanho e ao efeito de contraste gerado pelo fundo escuro da composição. Uma vez dispostos de forma equilibrada, os elementos dos modos são percebidos e lidos conjuntamente. $O$ gênero, uma via de mão única mediada pela mídia, portanto, responde bem às exigências de gestão governamental.

Mas, como o evento é de natureza sociocultural, a análise da forma de comunicação é crítica, porque aciona significados que favorecem, apenas e exclusivamente, uma parte que constitui o Estado Nação, o Poder do Executivo. Como os poderes legislativos e judiciários não são simbolizados no texto, ao Poder Executivo é garantido o poder com exclusividade. 


\subsection{Representação narrativa}

As colunas do Palácio do Planalto ${ }^{31}$ representadas sob uma perspectiva de ângulo elevado e frontal sobre um pano de fundo escuro não modalizado, criam envolvimento com os leitores do texto (VAN LEEUWEN, 2005). Na imagem em que há uma cruz ${ }^{32}$ inserida no centro esquerdo do design, os recursos usados evocam direcionalidade, poder e solidez do Estado-Nação. Esses recursos são: a elevação da linha vertical que ultrapassa a expressão Brasília 50 ANOS; o triângulo formado pelo vértice das colunas; e o alongamento da linha horizontal (à esquerda) sob a qual aparece modalizada a expressão: $\boldsymbol{O}$ nascimento de uma nação.

Embora pareça uma estrutura conceitual, a estrutura narrativa se constitui do processo de ação não transacional (KRESS e VAN LEEUWEN, 2006). A cruz que divide o formato do gênero em quatro frames de tamanhos distintos, cujas linhas emolduram dois lados de cada frame, é o vetor do processo de ação não transacional. Nessa representação narrativa, há apenas um participante representado: as colunas do Palácio do Planalto, do qual o vetor (a cruz) emana e com o qual se relaciona. Não há um objetivo, mas uma vez que o evento cultural é representado na perspectiva de ângulo frontal, o leitor é envolvido pela composição.

Os quatro frames formados pela cruz remetem às quatro escalas hierárquicas do plano original urbanístico de Lúcio Costa para Brasília: i) o eixo monumental (onde estão os palácios e os ministérios); ii) a escala gregária no cruzamento dos eixos (onde ficam a rodoviária e os centros comerciais); iii) a escala residencial (onde estão as superquadras); iv) a escala bucólica (onde estão as enormes áreas verdes e os parques de Brasília), com o objetivo de dar legitimidade a um presente obscuro e ininteligível.

\footnotetext{
${ }^{31}$ Palácio do Planalto é o nome oficial do Palácio em que está localizado o Gabinete da Presidência da República Federativa do Brasil. O prédio também abriga a Casa Civil, a Secretaria-Geral e o Gabinete de Segurança Institucional da Presidência da República. É a sede do Poder Executivo do Governo brasileiro. O edifício está localizado na Praça dos Três Poderes em Brasília, tendo sido projetado por Oscar Niemeyer e inaugurado em 21 de abril de 1960.
}

${ }^{32} \mathrm{~A}$ cruz simboliza o cruzamento do eixo monumental com o eixo rodoviário em Brasília. 


\subsection{Modalidade}

Elaborada em uma perspectiva de ângulo (frontal e elevado) a composição multimodal tem um estética que atrai e envolve o público receptor. $A$ imagem que identifica Brasília, como Patrimônio Cultural da Humanidade, contrasta o fundo - escuro, vazio e desarticulado. O layout concêntrico da imagem acomoda outras interpretações e dá margem para que uma gama de elementos sejam relacionados.

Segundo o critério naturalista (VAN LEEUWEN, 2005), as colunas do palácio tem alto grau de modalidade porque o seu design se aproxima da forma como as colunas do Palácio do Planalto são vistas na realidade e porque a paisagem multimodal é equilibrada. A qualidade sensorial da imagem está na forma estilizada e no modo de representação do participante. Cada parte que o constitui pode ser lida separadamente, devido à cruz que emoldura as suas quatro partes (atributos do participante representado), mas o seu tamanho e o efeito de contraste causado pelo fundo obscuro suprime as diferenças e as divisões existentes, de modo que a identidade cultural é interligada ao todo aparentemente novo.

\subsection{Ideologia e efeito social da narrativa}

Os significados construídos no gênero por modos da ideologia, como a narrativização e a simbolização da unidade (THOMPSON, 2011), têm efeitos sociais potenciais. O deslocamento de um símbolo (a cruz) que remete a uma tradição dignificante e eterna e o seu encaixamento dentro de um gênero global (as Colunas do Palácio do Planalto) pode até despertar o sentimento de dignidade e de pertencimento à nação, mas, como a realidade em sua essência é heterogênea, o real propósito da mensagem é promulgar e perpetuar o poder.

Análise do Texto A1 revela, portanto, como, em determinada circunstâncias, a mídia nacional, por meio do uso do gênero global, age estrategicamente para legitimar o poder e para que este seja amplamente reconhecido. 
5.1.2.2 Análise do Texto A2

Figura 48 - 50 anos de Brasília

Veja,11/2009, Edição Especial

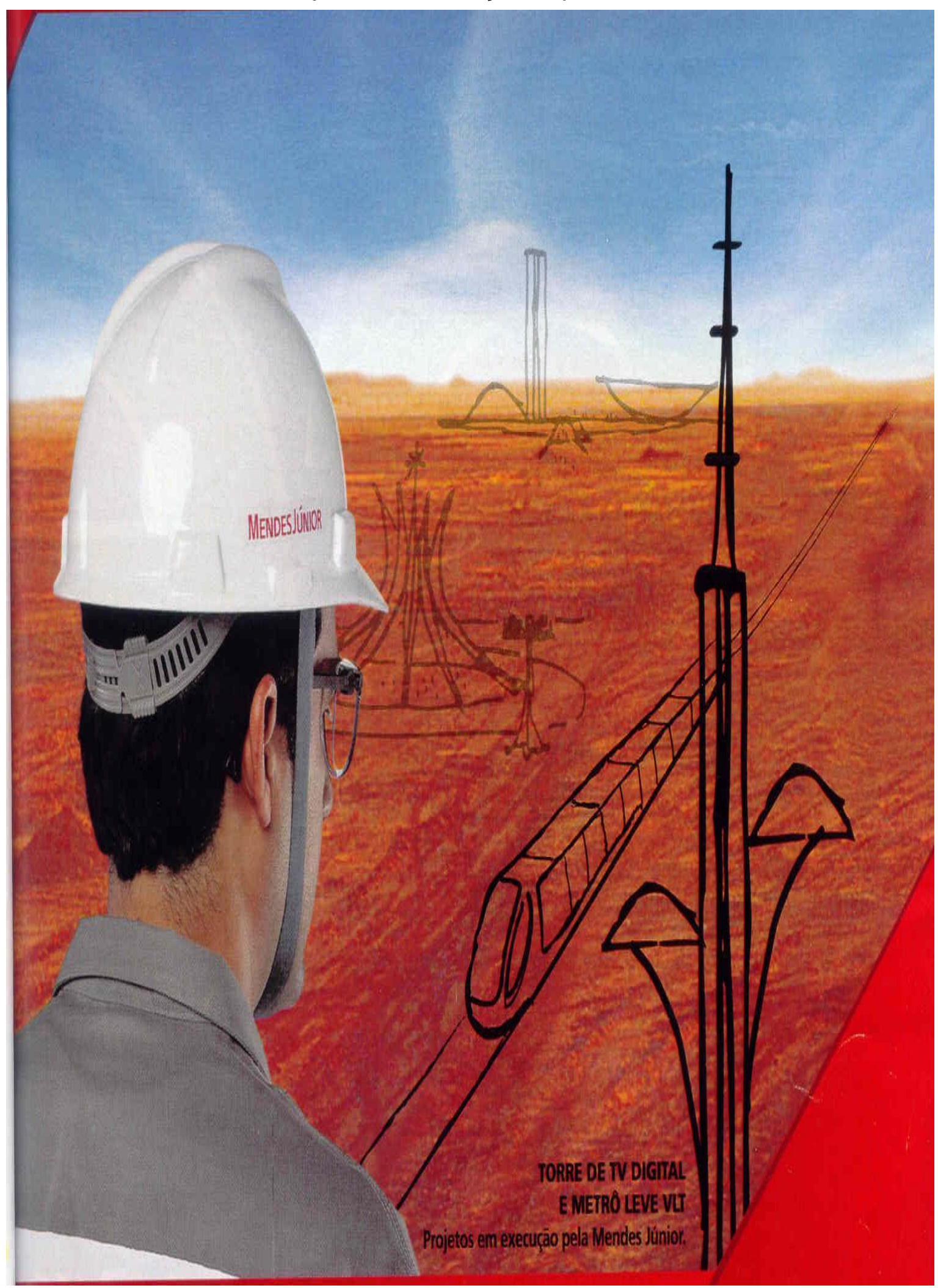

Fonte: Abril, ano 42, n. 2.138, p. 60. 


\subsection{Gênero discursivo e global}

A narrativa, um gênero de governança (FAIRCLOUGH, 2003), fruto da recontextualização do evento cultural de domínio público (50 anos de Brasília) compõe-se de foto, de imagem e do modo da escrita que complementa o sentido do texto predominantemente visual (MACHINE e VAN LEEUWEN, 2007). O gênero de texto recontextualizado pela prática empresarial, cujo cenário político ${ }^{33}$, no plano médio do texto, tem como propósito promover uma empresa privada.

O encaixamento da foto de um supervisor da Mendes Júnior, logo no primeiro plano da imagem, é o mecanismo usado na organização do gênero de governança, por meio do qual a Empresa prestadora de serviços ao Governo estabelece relações de poder com este. A incorporação do argumento visual prático é um recurso semiótico utilizado eficiente para a tomada de decisões (CASTELLS, 2009) favoráveis aos interesses econômicos da Empresa. Planejada para ter efeitos de curto prazo (MACQUAIL, 2013) sobre a cognição social, a produção dessa representação narrativa faz parte das ações estratégicas da empresa Mendes Júnior.

\subsection{Representação narrativa}

O participante principal da estrutura narrativa (o homem de uniforme cinza com o capacete da empresa) é ligado aos participantes meta (o metrô e a torre digital), por meio do vetor do processo de ação transacional: a linha do metrô. Salientado no primeiro plano da imagem por seu tamanho e altura e, por efeito de um cenário vermelho modulado, o participante ator é representado na perspectiva de ângulo perpendicular e oblíquo, com o objetivo de promover a imagem da incorporadora. Mas, o processo narrativo transacional também agencia um processo mental.

Com efeito, o metrô que transita sobre a via ascendente sobreposta ao cenário político é o fenômeno do processo mental, para o qual o olhar do reator

${ }^{33}$ A Praça dos Três Poderes, identificada pelo desenho do Congresso Nacional e pela Catedral Metropolitana, é um cenário que inclui dois empreendimentos da Empresa Mendes Júnior: o Metro e a Torre Digital. 
(supervisor de obra) se dirige. Nesse caso, o vetor do processo narrativo mental é o olhar do reator. O ponto de vista do produtor do texto assemelha-se ao do supervisor da empresa (reator do processo mental), representado sob a perspectiva de ângulo oblíquo, em que um lado do reator é visível e o outro oculto. $\mathrm{Na}$ estrutura narrativa mental, a Torre de TV, salientada como algo novo (à direita do layout), tem valor informativo, mas, no todo composicional, é apenas uma circunstância que reforça, positivamente, a imagem da empresa. Apesar da diferença observada entre os processos transacional e mental representados, propósito da narrativa midiática multimodal é o mesmo: satisfazer interesses promocionais e, consequentemente, viabilizar a realização dos objetivos econômicos da Empresa prestadora de serviços ao Estado.

\subsection{Modalidade}

No texto multimodal, em foco, vários aspectos visuais chamam a atenção: a saturação e modulação da cor vermelha do cenário no plano médio; o contraste entre cores em que o azul celeste serve como pano de fundo; os planos da imagem sobre os quais o ângulo perpendicular (altura) do participante principal representado se sobrepõe; e o tamanho deste participante. A saturação e a modulação do vermelho, por exemplo, criam um efeito sensorial de artificialidade. $O$ efeito de profundidade marcado pelo azul do ceu, segundo os critérios do naturalismo-padrão, tem maior modalidade (KRESS e VAN LEEUWEN, 2006), mas nessa composição, o ângulo perpendicular e a saliência do participante ator representado, tornam o pano de fundo abstrato e etéreo. Assim, o sentido positivo e realista concentra-se na representação do participante ator.

A credibilidade das narrativas midiáticas baseia-se no conhecimento das fotografias como uma representação naturalística da realidade. A foto encaixada no gênero mostra detalhes do participante ator representado. Apesar da qualidade do texto, não há, em nossa cultura, a prática de valorização do trabalhador da construção civil. A análise dos marcadores da modalidade usados no texto aponta, portanto, para uma forma ideológica estrategicamente manipulada para ter efeitos sociais. 
5.1.2.2.4 Ideologia e efeitos sociais da narrativa

Os significados evocados pela estrutura narrativa têm efeitos sociais de curto prazo e de longo prazos que satisfazem os interesses da empresa. O que contribui para o alcance dos resultados planejados são os seguintes aspectos: 0 modo de representação do participante ator (supervisor de obra da empresa), a ênfase dada a este agente semântico e a ideologia incorporada ao gênero: a reificação por naturalização, modo de operação estratégico da ideologia que representa que leva os receptores do texto a ver um acontecimento, fruto de uma criação particular, como natural. Esses aspectos esvaziam o caráter sóciohistórico do evento cultural (o aniversário da Capital do Brasil) para dar lugar a uma situação transitória como se permanente.

O texto veiculado pela revista é uma representação estratégica eficaz ao exercício da dominação, a qual pode ser utilizada apropriadamente pela empresa em outros contextos. O modelo pode ser recontextualizado, com relativa facilidade, e utilizado por outras empresas com fins lucrativos. 


\subsection{Texto B}

Contextualização

A narrativa midiática multimodal veiculada pela revista Veja (Figura 49), trata de tema sociopolítico: as manifestações populares.no Brasil, o qual tem sido coberto pela grande mídia, desde quando o movimento popular contra o aumento da tarifa do transporte, contra a corrupção no Brasil e contra a falta de investimentos em saúde e em educação no Brasil, tomou corpo com a adesão, sem precedente, de manifestantes em vários Estados do Brasil. A narrativa, a seguir, foi difundida pela revista Veja, após o ápice do movimento que, em meados de junho de 2013, já contava com o apoio de $84 \%$ da população brasileira.

Figura 49- Manifestação popular

Revista Veja, 3 de julho de 2013

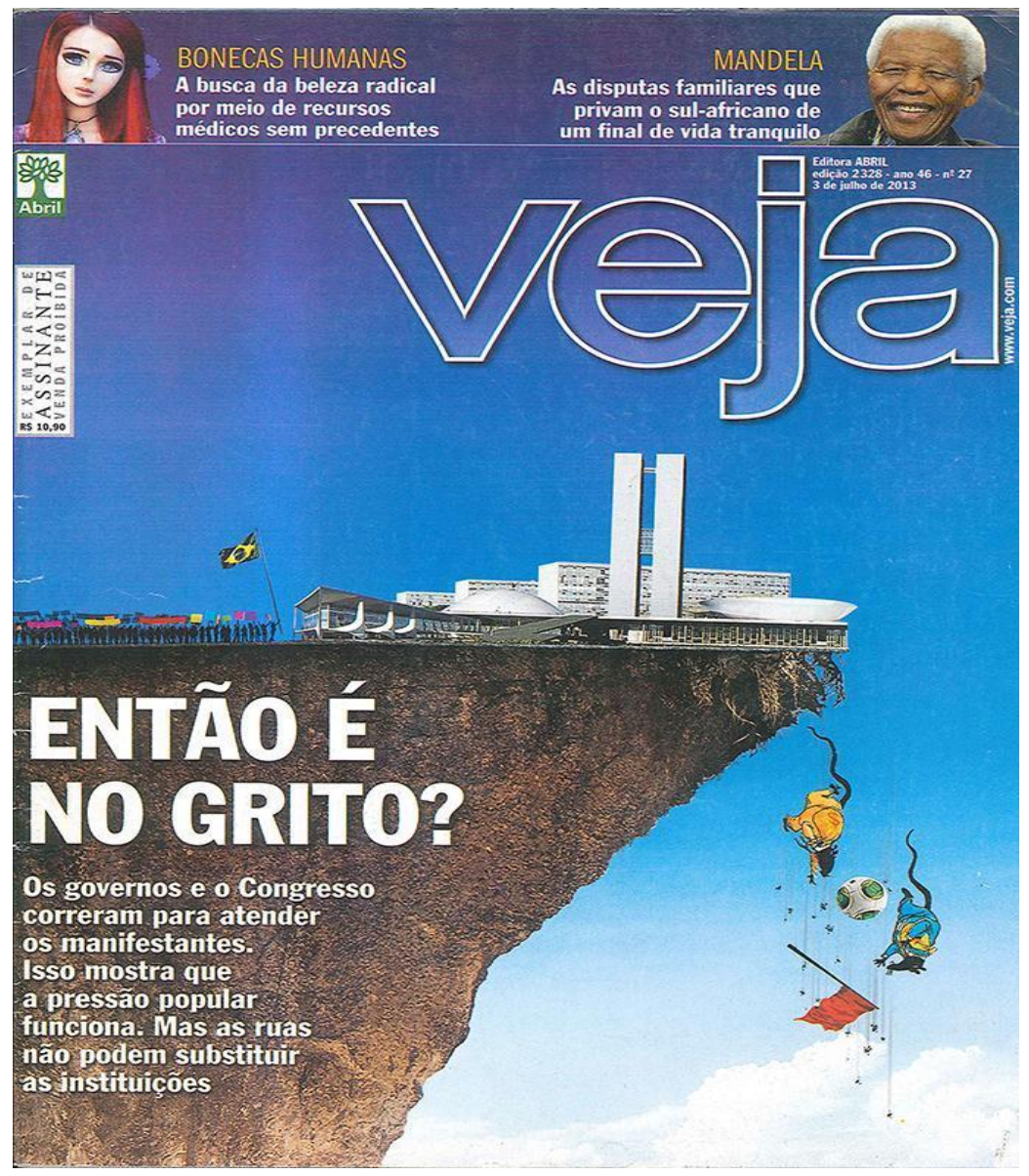

Fonte: Abril, Edição 2.328, ano 46, n. 27. 


\subsubsection{Contexto global e local}

O contexto que controla a produção desse texto midiático (VAN DIJK, 2011), compreende a instabilidade inerente do sistema capitalista, a crise financeira global que tem como epicentro os EUA e os países desenvolvidos da Europa e a subestimação do risco sistêmico, fatores que refletem na economia de países em desenvolvimento como o Brasil e em diversos países do mundo, mas são dissimulados e atribuídos aos efeitos sociais que esses aspectos contextuais causam.

No Brasil, os protestos e as manifestações que ocorreram, de forma progressiva, em vários estados, contra a crise financeira e política moral, só foram cobertos pela mídia quando já contavam com o apoio massivo da população brasileira. A representação narrativa difundida na capa da revista brasileira mobiliza significados semióticos complexos e problemáticos.

Apesar de a recessão mundial já ter provocado alguns estragos na economia brasileira com a queda da taxa de crescimento do produto interno bruto, o Brasil poderia estar em situação melhor se esforços de gestão e a mídia nacional pudessem contribuir para a realização de reformas inadiáveis como as da previdência, da educação e da saúde. O incentivo do setor privado, do poder político e da sociedade brasileira para a redução de gastos funcionais e para a criação de políticas públicas sociais voltadas à diminuição das desigualdades sociais, certamente, minimizaria riscos iminentes.

Em um regime democrático, a competição e a luta do povo para um final cooperativo (FAIRCLOUGH e FAIRCLOUGH, 2012) devem ser vistas como um processo sociopolítico legítimo e não como processo violento e criminoso. No processo de luta coletiva contra as estruturas injustas e antidemocráticas, a revista Veja e outros meios institucionais de comunicação são utilizados como chave para o controle de ações e de reações contra o sistema; o que representa uma forma de violência simbólica legitimada. 


\subsubsection{Contexto do evento social}

As primeiras manifestações populares contrárias ao aumento das tarifas de transporte urbano municipal ocorreram no Rio de Janeiro com cerca de apenas 500 manifestantes em 2012. Em Natal, após o anúncio do aumento das passagens, uma manifestação organizada pelo movimento Revolta do Busão, reuniu cerca de duas mil pessoas, mas foi duramente reprimida, pela Polícia Militar. Em Porto Alegre (RS), os protestos ganharam mais força após o reajuste das passagens no início de 2013.

Figura 50 - Rio de Janeiro

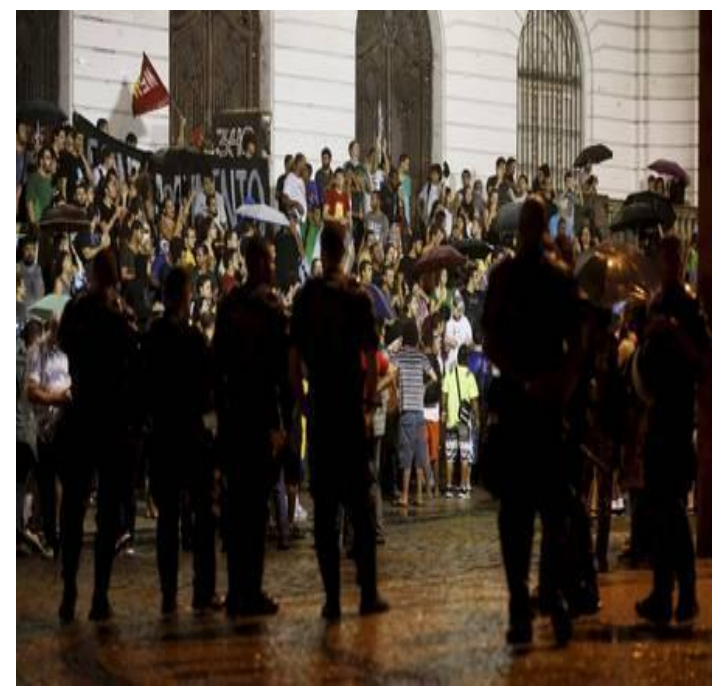

Fonte: <http://pt.wikipedia.org/wiki/Protestosl>.
Figura 51 - Natal

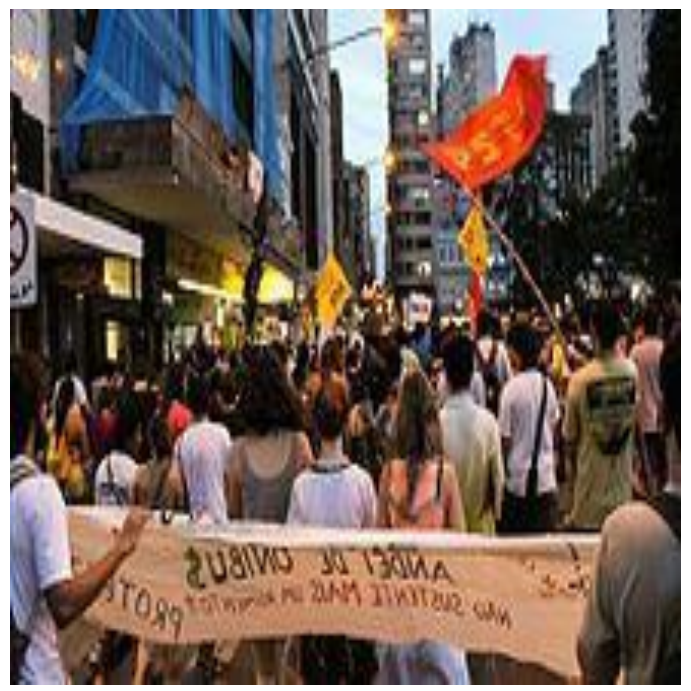

Fonte: <http://pt.wikipedia.org/wiki/Protestos>.

\section{Figura 52 - Porto Alegre}

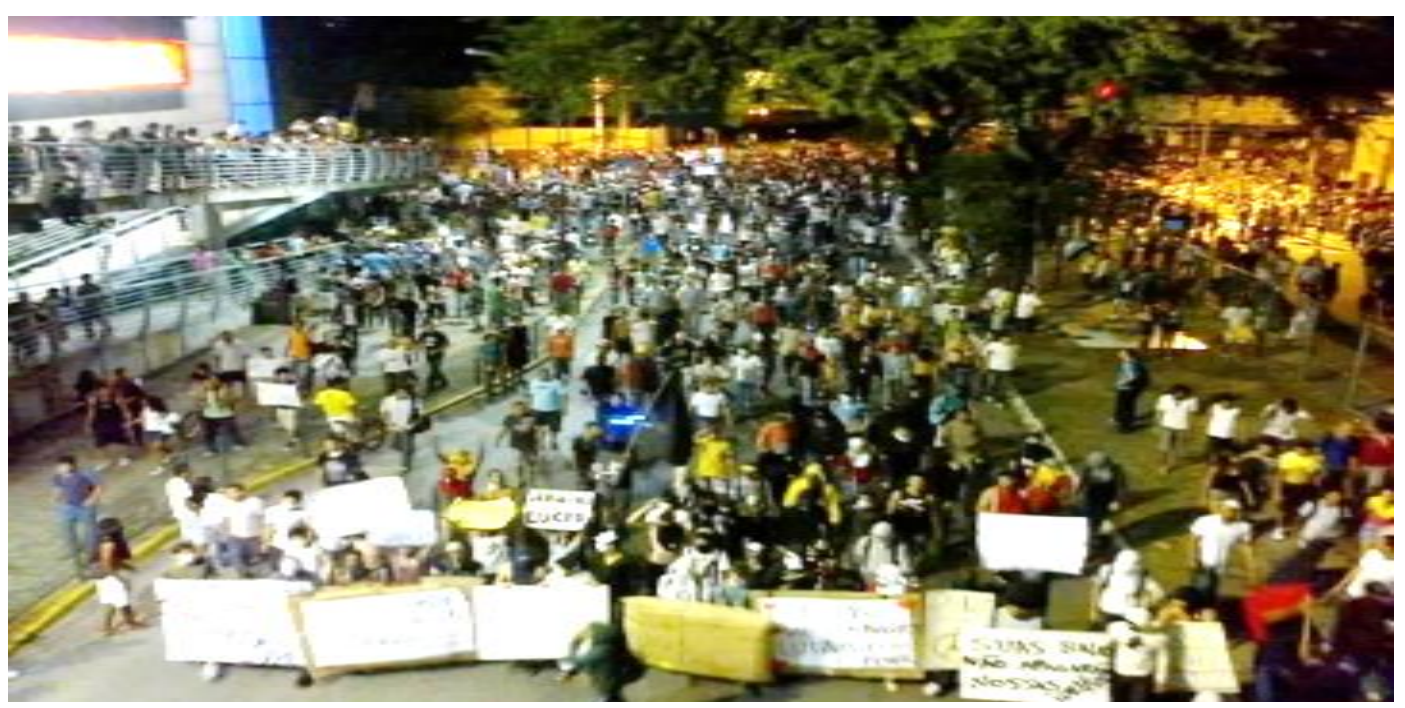

Fonte: <http://pt.wikipedia.org/wiki/Protestos_no_Brasil>. 
O aumento quase simultâneo das tarifas em maio de 2013 desencadeou manifestações nas principais capitais do país, principalmente em São Paulo, quando a insatisfação social ocasionou a diversificação das causas dos manifestantes.

Figura 53 - São Paulo

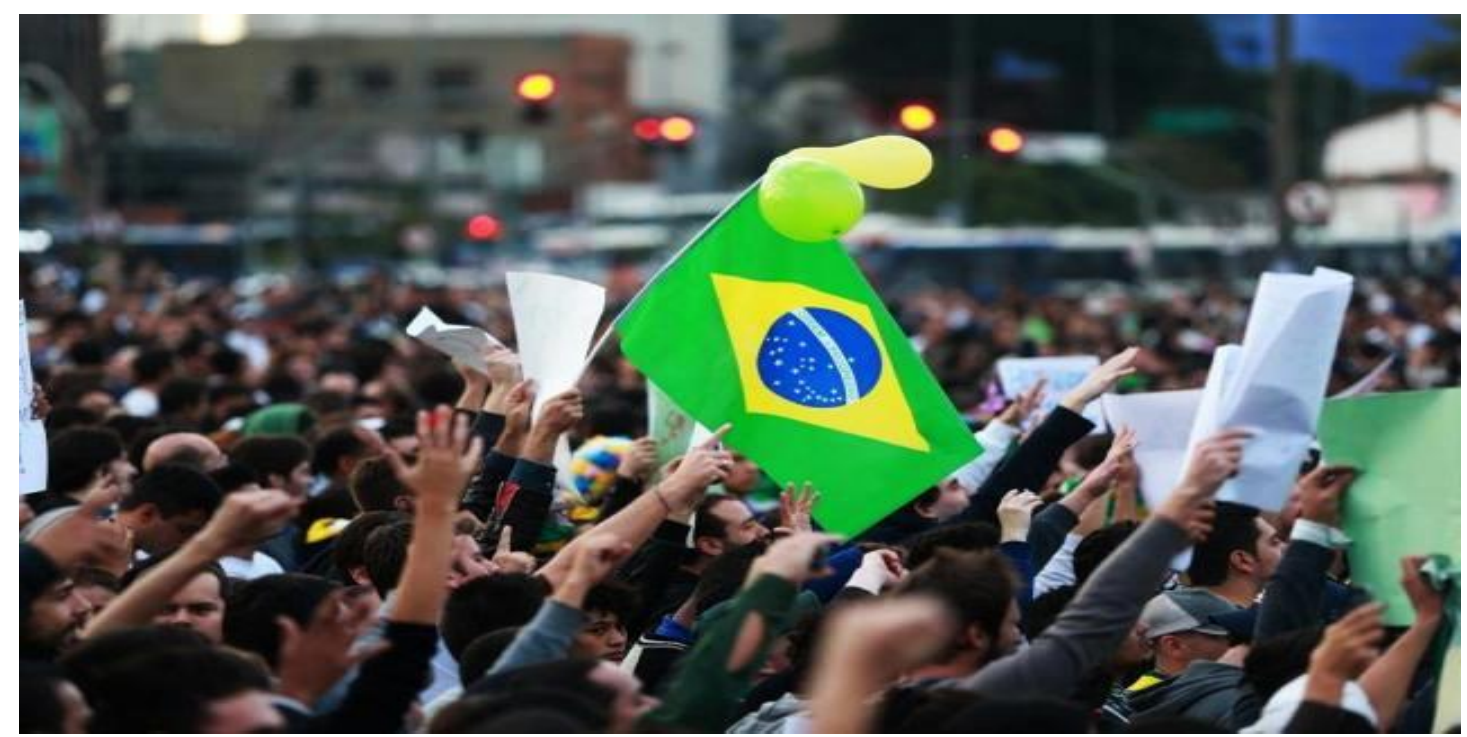

Fonte: <http://pt.wikipedia.org/wiki/Protestos_no_Brasil_em_2013>.

Protestos contra os gastos públicos na Copa do Mundo, contra a falta de investimentos em saúde e educação e, principalmente, contra a corrupção, após a forte repressão policial contra os manifestantes em São Paulo no dia 13 de junho de 2013, ocorreram no restante das cidades brasileiras.

Figura 54 - Capitais do país

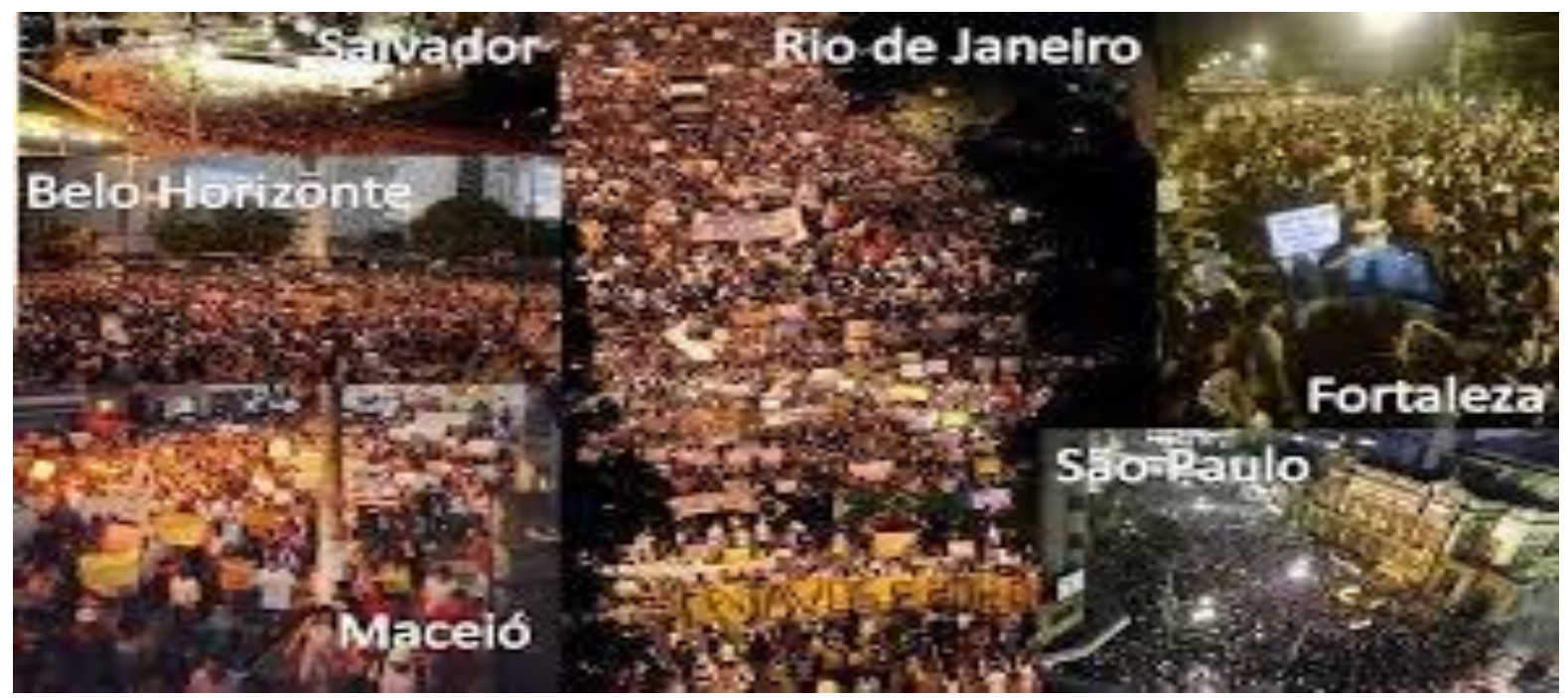

Fonte: <http://pt.wikipedia.org/wiki/Protestos_no_Brasil_em_2013>. 
As maiores manifestações foram registradas no Rio de Janeiro, quando os protestos e as manifestações cobertas pela mídia nacional e global repercutiram de modo impactante no mundo globalizado.

Figura 55 - Rio de Janeiro

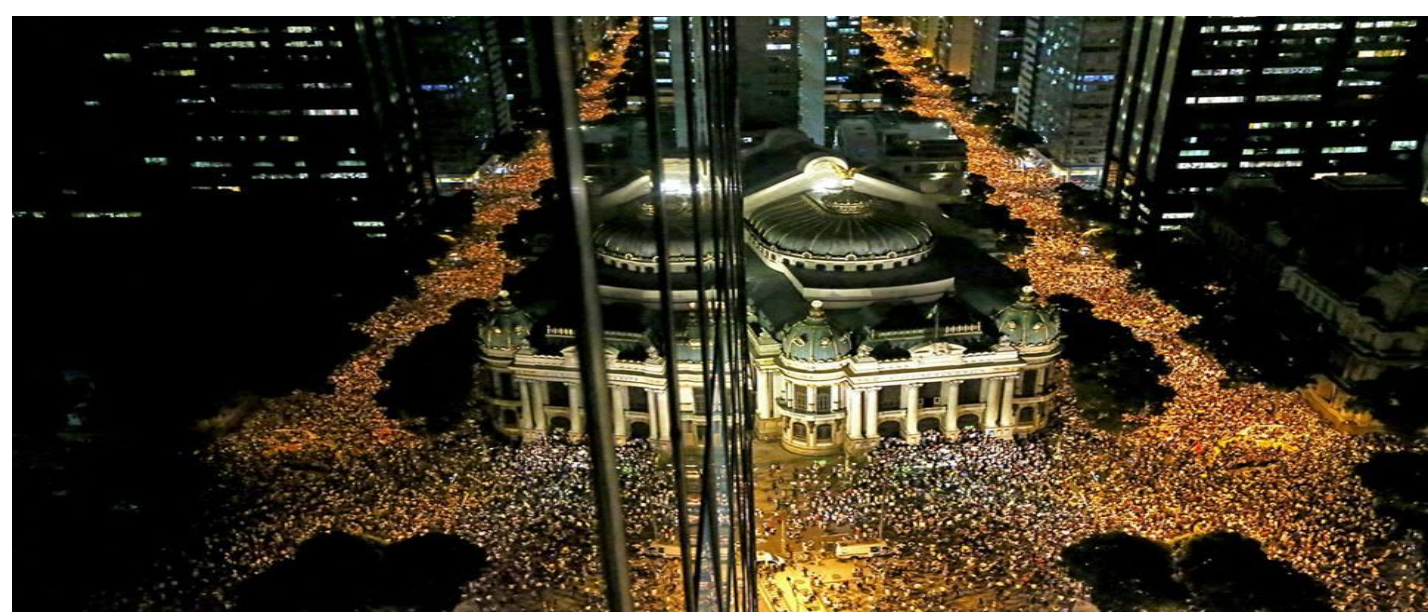

Fonte: <http://pt.wikipedia.org/wiki/Protestos_no_Brasil_em_2013>.

Em Portugal e na Espanha, manifestações de apoio em solidariedade ao movimento ocorreram em 18 e 20 de junho de 2013.

Figura 56- Protestos em Lisboa

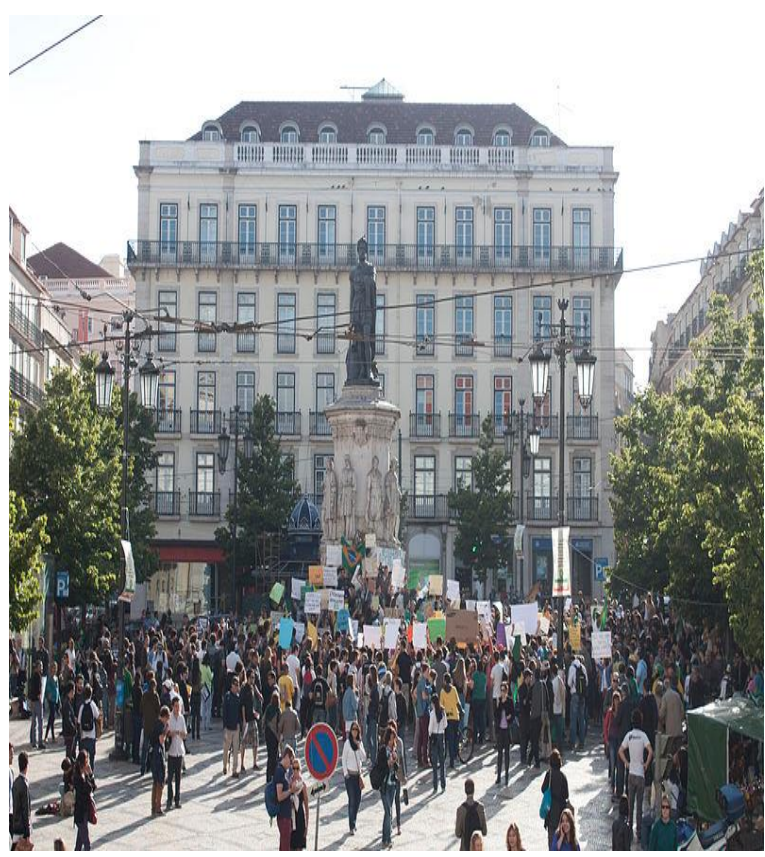

Figura 57 - Protestos em Salamanca

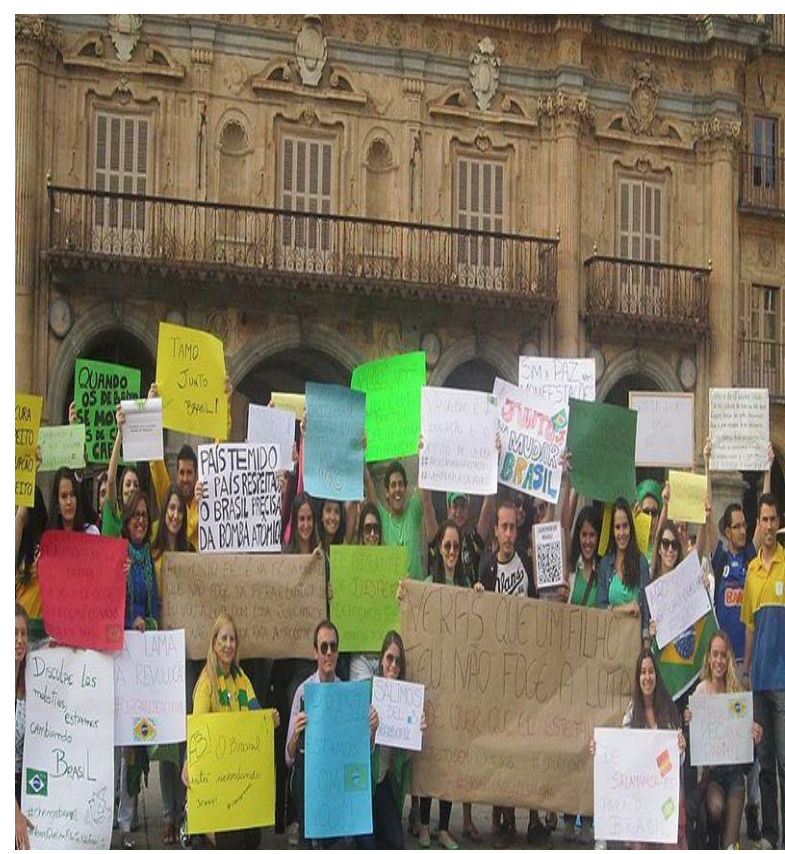

Fonte: <http://pt.wikipedia.org/wiki/Protestos_no_Brasil_em_2013>. 
Em 20 de junho de 2013, cerca de 35 mil pessoas ocuparam a Esplanada dos Ministérios em Brasília. Vidros dos Prédios foram apedrejados, holofotes foram destruídos e paredes foram pichadas. Um manifestante chegou a atirar uma bomba incendiária que queimou parte da fachada do Congresso Nacional. A polícia militar conseguiu conter apenas os manifestantes mais exaltados.

\section{Figura 58 - Brasília}

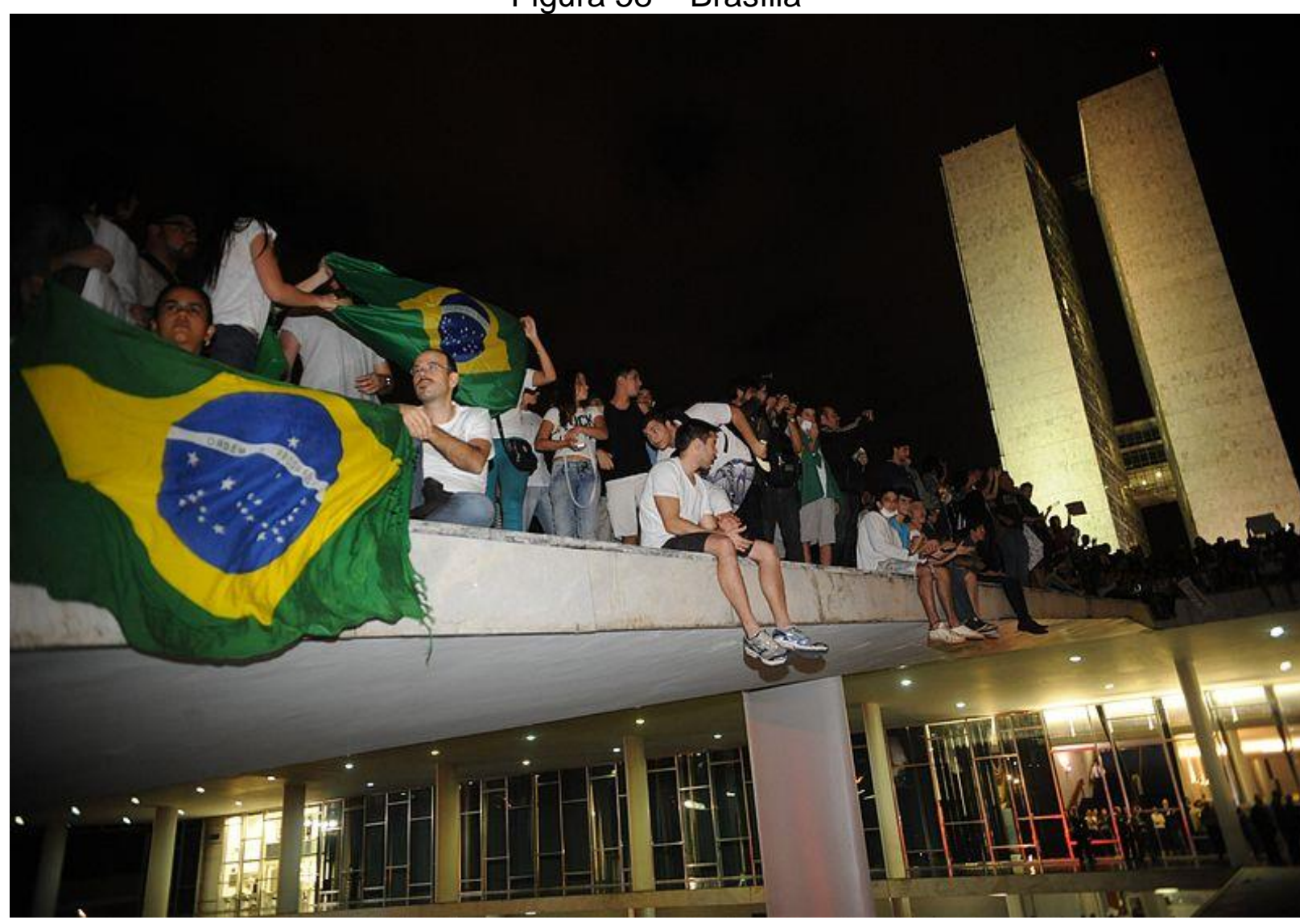

Fonte: <http://pt.wikipedia.org/wiki/Protestos_no_Brasil_em_2013>.

Em resposta, o Governo anunciou medidas para tentar atender às reivindicações dos manifestantes. O Congresso Nacional votou uma série de concessões, como, por exemplo, ter tornado a corrupção um crime hediondo. $O$ Governo cancelou a PEC 37 que proibia investigações pelo Ministério Público e o voto secreto para cassação de mandatos de legisladores acusados de irregularidades. Houve também a revogação dos recentes aumentos das tarifas nos transportes em várias cidades do país, com a volta dos preços anteriores. 
As manifestações organizadas por meio das redes sociais, em junho de 2013, por movimentos sociais que buscavam solucionar o problema econômico político tiveram duas fases demarcadas por características distintas. Na primeira fase, não houve apoio da mídia, a participação popular foi pequena, houve muitos conflitos violentos entre os manifestantes e a polícia militar. Com o exponencial aumento do número de participantes e a violenta repressão policial que deixou vários manifestantes feridos, a mídia resolveu noticiar, o que classificou como vandalismo. A segunda fase dos protestos, marcada por manifestações majoritariamente pacíficas e por massiva participação popular, teve grande cobertura midiática.

Em 12 de junho, o jornal Folha de S. Paulo criticou as manifestações do dia anterior, acusando os manifestantes de vandalizarem vias da cidade. $O$ jornal um dia depois defendeu em seu editorial que os manifestantes eram jovens, predispostos à violência por uma ideologia pseudorrevolucionária, que buscavam tirar proveito da situação e atrair a atenção pública para prejudicar o número máximo de pessoas.

O jornal também defendeu as intervenções da polícia. Mas, após ter vários de seus repórteres feridos por ações policiais, afirmou que polícia havia protagonizado um espetáculo de despreparo e de controle mais grave que o vandalismo que tinha por missão coibir. O jornal $O$ Estado de $S$. Paulo tomou um posicionamento similar ao da Folha de S. Paulo em 12 de junho, ao dizer que a violência tinha sido a marca do protesto, após considerar moderada a reação da Polícia Militar.

No dia 12 de junho, o jornal $O$ Globo referiu-se aos protestos no Rio de Janeiro como "a marcha da insensatez" e na edição do dia 13 de junho afirmou que os organizadores foram os responsáveis pelos atos de vandalismo, ainda que não tivessem controle da situação. No mesmo parágrafo, ainda acusavam as causas reivindicadas de artificiais, invalidando os protestos do movimento.

A revista Veja São Paulo acusou o movimento de provocar doses de barulho e de confusão inversamente proporcionais ao seu tamanho. Na mesma edição, afirmou que os manifestantes protestavam sempre nas artérias principais 
da cidade para chamar atenção, causando a maior balbúrdia possível e prejudicando incalculável número de cidadãos.

À tarde, falando pela primeira vez sobre os protestos, a Presidente Dilma Rousseff declarou ao NBR (Canal de Televisão do Brasil) que o seu Governo ouviu as vozes da mudança e que estava empenhada e comprometida com a transformação social.

Figura 59 - Pronunciamento da Presidente do Brasil

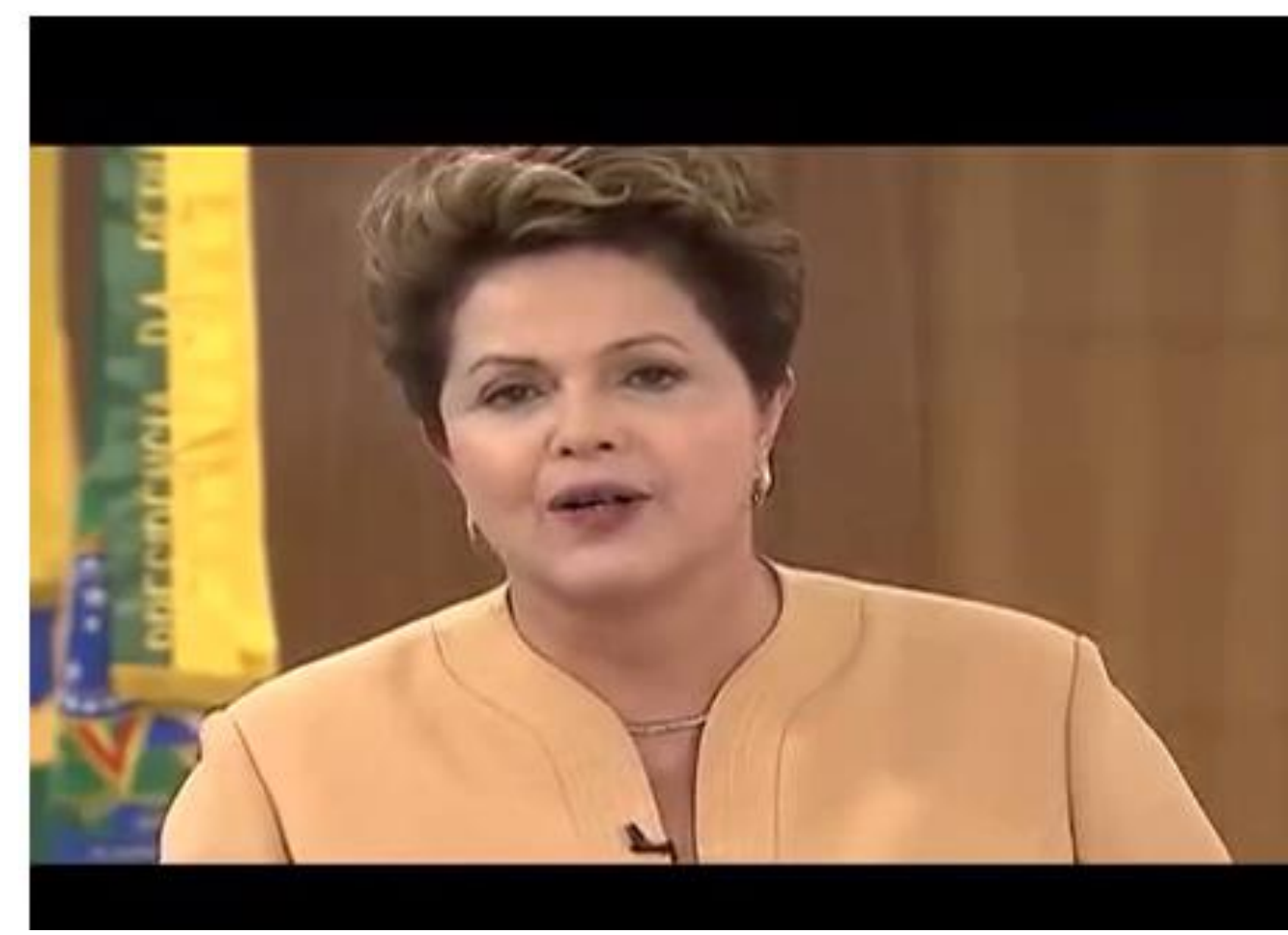

Fonte: <http://pt.wikipedia.org/wiki/Protestos_no_Brasil_em_2013\#Pronunciamento_presidencial>.

Em seu pronunciamento, a Presidente do Brasil, Dilma Houssef, comprometeu-se com a melhoria dos serviços públicos e a criação de um Plano Nacional de Mobilidade Urbana. Prometeu destinar $100 \%$ do dinheiro dos royalties do petróleo à educação, ampliar o atendimento do SUS e realizar uma reforma para ampliar o poder popular. Mas, em relação aos protestos contra a diretriz econômica de seu Governo, ressaltou que quem definiria os rumos da política econômica brasileira trabalhava no terceiro andar do Palácio do Planalto. 
Figura 60 - Manifestação popular

Revista Veja, 3 de julho de 2013

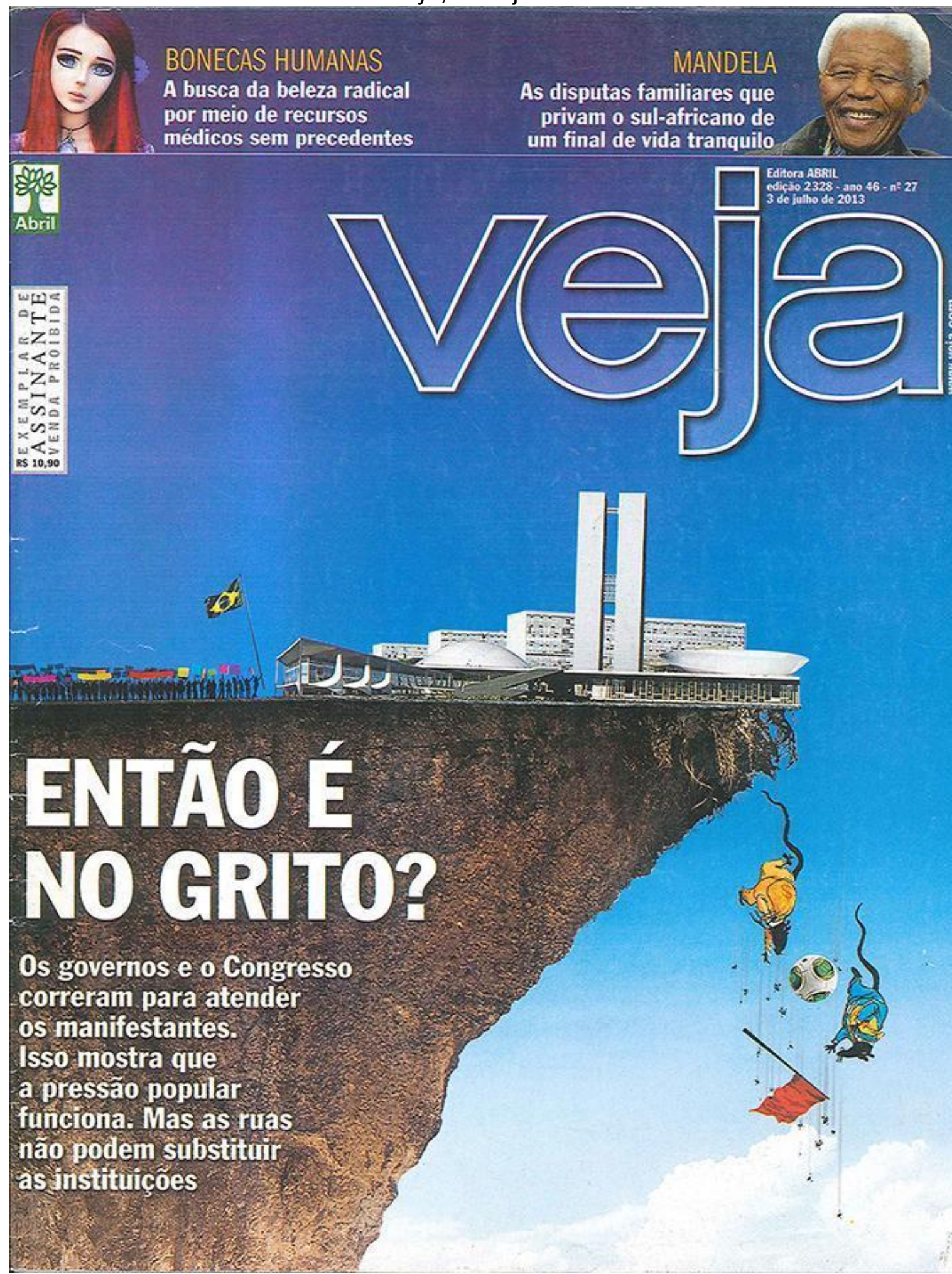

Fonte: Abril, Edição 2.328, ano 46, n. 27. 


\subsection{Gênero discursivo e global}

Os estudos sociolinguísticos distinguem a narrativa literária ou ficcional da narrativa jornalística, classificando-as por suas diferenças estruturais. Enquanto a liberdade de imaginação e a estetização tipificam a narrativa ficcional, o efeito de veracidade dos fatos relatados é o que caracteriza a narrativa jornalística. A narrativa focalizada (Figura 60), porém, entrelaça os gêneros para alcançar um resultado. O texto veiculado na capa da revista Veja veicula significados com potencial para evitar o prolongamento das manifestações, ou mesmo conter o movimento nas cidades brasileiras.

Do ponto de vista do gênero discurso (FAIRCLOUGH, 2003), o texto classifica-se como uma quase forma de (inter)ação mediada pela mídia impressa, como um formato tecnológico mais ou menos abstrato constituído pelo processo de encaixamento de texto e de imagem. Como parte do aparelho de governança do Estado-Nação, o gênero discursivo transcende redes de comunicação e escalas. Do ponto de vista do gênero global (MACHIN e VAN LEEUWEN, 2007), a narrativa é um gênero do tipo problema-solução, composto com recursos semióticos do modo da escrita e do modo visual. O problema e a solução são representados por meios de ambas os modos da linguagem. O problema, elemento mais salientado, é representado por ambas as modalidades da linguagem.

A análise do modo da escrita mostra que na manchete em que a voz do narrador é incorporada (ENTÃO É NO GRITO?), o problema é imediatamente exposto, e que, embora o contexto do evento sociopolítico não esteja explicitado, há sequências de nível menor na narrativa: “(...) manifestantes; (...) pressão popular (...).", que permitem ao leitor do texto deduzí-lo. A análise também mostra que o texto verbal, encaixado no todo composicional coerente, organiza-se com uma sequência distinta da ordem lógica e cronológica do evento original ( as consequências do evento principal antecedem o próprio evento principal), e que, no comentário conclusivo do texto,há um ponto de vista persuasivo (FAIRCLOUGH, 2003): 


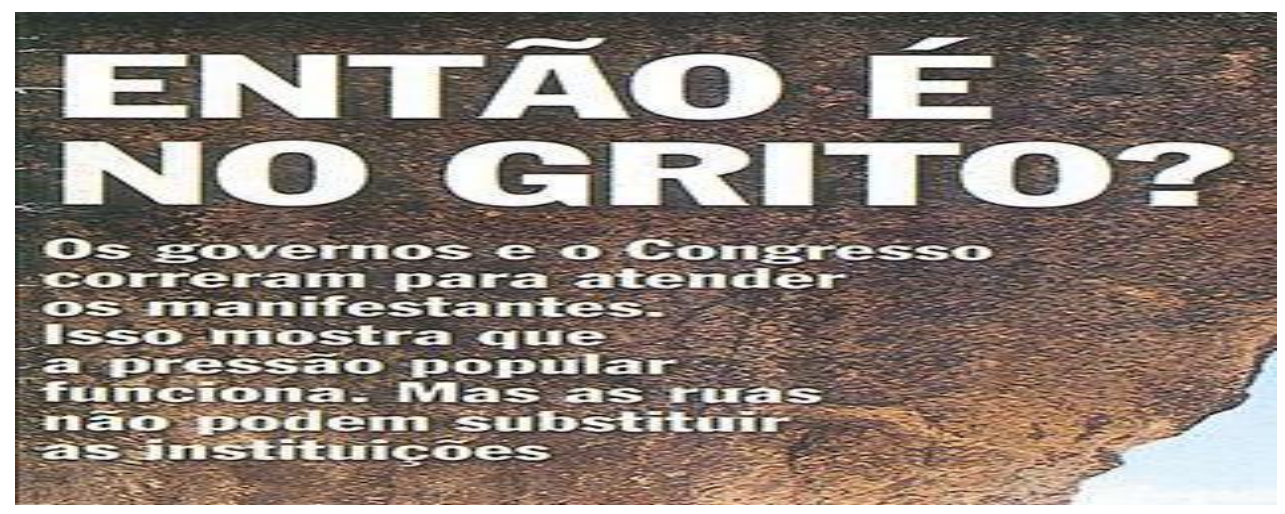

A análise da macroestrutura do gênero discursivo mostra o exposto:

MANCHETE

\section{ENTÃO É NO GRITO?}

\section{CONTEXTO SOCIAL}

O contexto do evento não está claramente explícito, mas as sequências de nível menor no texto, tais como (...) manifestantes (...) pressão popular, o sugerem.

CONSEQUÉNCIA EXPLÍCITA DO EVENTO PRINCIPAL

Os governos e o Congresso correram para atender os manifestantes.

EVENTO PRINCIPAL

(...) a pressão popular funciona.

COMENTÁRIO

Mas as ruas não podem substituir as instituições. 
A macroestrutura do gênero textual, como vimos, é bastante simples. 0 contexto é deduzido de sequências de nível menor; os eventos prévios são suprimidos do texto; as consequências do evento sociopolítico antecedem o próprio evento; e o comentário persuasivo "Mas as ruas não podem substituir as instituições", é apontado como solução do problema.

Como já mencionado, em uma sociedade democrática a luta popular deveria ser vista e representada como um fenômeno voltado para um fim cooperativo manifestado publicamente, como uma decisão coletiva destinada à resolução de desacordos e de problemas (FAIRCLOUGH, 2012, p. 30). Sob essa perspectiva, a democracia seria entendida tal como é: um dispositivo de institucionalização do processo dialético criado por uma estrutura política que dá plena oportunidade ao uso de competição para um final cooperativo.

\subsection{Representação narrativa}

Esta representação narrativa (KRESS e VAN LEEUWEN, 1996,2006) estrutura-se por meio de processo de ação transacional agentivo que envolve dois tipos de participantes ligados por um vetor. O participante principal da estrutura de ação é o grupo de manifestantes com faixas coloridas e a bandeira do Brasil em mãos posicionados à esquerda da capa da revista.

O participante-meta representado são os órgãos institucionais (o Palácio do Planalto e Ministérios e o Congresso nacional) posicionados no centro do design de capa da revista Veja. A estrutura semiótica tem como vetor a montanha invertida sobre a qual os participantes meta aparecem abismados. Os participantes atores são representados em tamanho pequeno e os participantes meta salientados no centro da composição. Os participantes meta diferenciam-se dos participantes atores por intermédio do ângulo elevado e frontal que cria relacionamento e envolvimento com o público receptor da mensagem.

Participantes secundários (os ratos), localizados à margem direita inferior da página da revista e representados como uma circunstância locativa são relacionados aos participantes atores, em virtude do modo como são configurados. Esta relação semântica é crítica e se estabelece por meio do uso de 
dois recursos semióticos, quais sejam: a direcionalidade do vetor e a equivalência estabelecida por marcador de modalidade.

O vetor da estrutura narrativa, isto é, a montanha sobre a qual os participantes atores e os participantes meta aparecem relacionados aponta para os participantes secundários, de modo que estes são relacionados aos participantes atores. Atributo comum portado por ambos é uma bandeira. A equivalência de sentido estabelecida entre os participantes secundários e os participantes principais dá-se, também, por intermédio de três recursos semióticos sutis: a cor (preta) usada nos corpos de ambos; a semelhança das cores da bandeira do Brasil portada pelos participantes principais e da bola de futebol com a qual aparecem os parlamentares (ratos); e a correspondência entre as cores das faixas levadas pelos manifestantes atores e as cores das roupas dos parlamentares expurgados. Os recursos metafóricos acessados para estabelecer correspondência entre os participantes mencionados são pouco razoáveis e contestáveis, porque sugerem que os participantes principais (os manifestantes), assim como os participantes secundários (ratos) são corruptos.

Os participantes meta diferenciam-se daqueles por intermédio de ângulo elevado e frontal que cria relacionamento e envolvimento com o público receptor da mensagem. Aspecto também relevante na estética dessa representação narrativa transacional é o aparente desequilíbrio dos elementos que fazem parte da organização do texto. O sentimento de medo, de insegurança e de ansiedade provocado pelos participantes atores (manifestantes) que "desafiam à lei da gravidade" tem como consequência o desmoronamento dos órgãos constitucionais. Mas, além da quase perda do equilíbrio que ameaça os participantes meta, o expurgo dos outros participantes representados no texto de capa da revista serve de meio para constranger os receptores da mensagem à tomada de decisões favoráveis à retomada do status quo.

\subsection{Modalidade}

No gênero global em foco, dois sutis marcadores de modalidade são observáveis. O primeiro, como já mencionado, diz respeito à cor (preta) usada 
como recurso semiótico que estabelece uma relação semântica entre os participantes atores e os participantes secundários, de maneira que aqueles são ameaçados. O segundo marcador de modalidade é a posição das nuvens que aparecem abaixo dos participantes secundários, a qual pode ser interpretada como um recurso semiótico usado para a libertação do castigo por atos de corrupção.

Os significados derivados do uso desses marcadores de modalidade são contraditórios e problemáticos, pois a representação da realidade conforme interesses políticos e econômicos não só desafia valores morais, mas nega o exercício da democracia como um modelo onde todos tem o direito de responder, de criticar e de avançar na solução de problemas.

Os estudos linguísticos distinguem as narrativas ficcionais das narrativas jornalísticas, classificando-as por suas diferenças estruturais. Mas, nesse caso, há semelhança genológica. A representação do evento sócio-histórico político com características de narrativa ficcional é proposital, mas gera um problema. A estética da narrativa jornalística ultrapassa os limites da sua responsabilidade de informar e assume um papel psicológico que provoca insegurança, ansiedade e medo; portanto, um papel averso à estabilidade e a ordem social.

\subsection{Ideologias e efeitos sociais da narrativa}

Dois modos de operação da ideologia são observados na narrativa midiática analisada: a dissimulação e a unificação. $O$ uso das metáforas discursiva (ruas=povo) e visual (ratos=parlamentares corruptos), no gênero, é a estratégia operacionalizada para dissimular as relações de poder e de dominação que controlam a produção do texto. Já o uso de bandeiras, simbolizando a unidade e de os marcadores de modalidade (cor dos corpos e das vestes dos participantes principais e secundários) que interliga os manifestantes aos parlamentares, independente das diferenças morais existentes entre eles, é a estratégia operacionalizada para a unificação da identidade. 
A representação narrativa midiática provoca sentimentos negativos e sentimentos opostos. O desafio à lei da gravidade representado como resultado do movimento popular, cuja consequência é o desmoronamento dos órgãos constitucionais gera ansiedade e insegurança. $O$ expurgo de parlamentares corruptos dos órgãos operacionalizado pela estratégia de fragmentação causa o sentimento de justiça, devido à revogação da PEC $37^{34}$, decisão que vai ao encontro do clamor popular, mas, ao mesmo tempo, provoca o sentimento de medo, em virtude de a estratégia de fragmentação da identidade estender-se aos participantes das manifestações populares.

Embora a solução para o problema moral existente no Brasil seja ficcional, por conseguinte, não razoável, a narrativa multimodal acessa sentidos que neutralizam o próprio valor da ação democrática. A generalização criada pelos marcadores de modalidade desencoraja a adesão a novos movimentos cívicos.

O propósito de fortalecer o Poder Político, deduzido do argumento prático e do modo como os participantes meta são representados na perspectiva de um ângulo que cria relacionamento e envolvimento com o público receptor da mensagem, poderia ser interpretado como positivo, se o uso da estratégia de fragmentação da ideologia incorporada na narrativa não fosse percebida. Nesse caso, o gênero global atingiria o seu propósito. O público leitor da mensagem internalizaria em sua memória episódica um modelo de contexto que distorce a realidade, e depois, agiria de modo inconsciente, em conformidade com os interesses do poder e da dominação. Contudo, não se pode assegurar os efeitos de sentido planejados pela representação narrativa.

Constatamos que a série eventos da realidade não é ordenada de acordo com a história original, que os agentes das ações são representados como personagens, e que não há neutralidade no gênero, mas persuasão. A narrativa, portanto, é uma forma de evitar o poder dos movimentos cívicos contrários à ordem estabelecida.

\footnotetext{
${ }^{34}$ Proposta de Emenda Constitucional $37 / 2011$ foi um projeto legislativo que, se aprovado, limitaria o poder de investigação criminal das polícias federais e civis e de outras organizações, como o Ministério Público. Disponível em: <http://pt.wikipedia.org/wiki/PEC_37>. Acesso em: 31 jan. 2015.
} 
Esperava-se que o evento fosse representado com os significados da real: de que o povo brasileiro admitiu ter errado na sua escolha e que busca mudanças pelas vias da Constituição Federal. Isso implicaria reconhecer que a mídia local contribuiu para a manutenção da falsa crença de que os brasileiros são coniventes com a corrupção, desrespeitam os bens alheios e que são indignos da confiança e da justiça social. 


\subsection{Texto C}

Contextualização

A narratival publicada na capa da revista The Economist remete à luta dos manifestantes ucranianos pelo estreitamento das relações com a União Europeia (UE), para o fim da intervenção russa na política da Ucrânia e para o estabelecimento de uma democracia baseada em regras e que substitua a cleptocracia do presidente Viktor Yanukovych.

Figura 61 - Estado da democracia

The Economist, 1 a 7 de maio de 2012

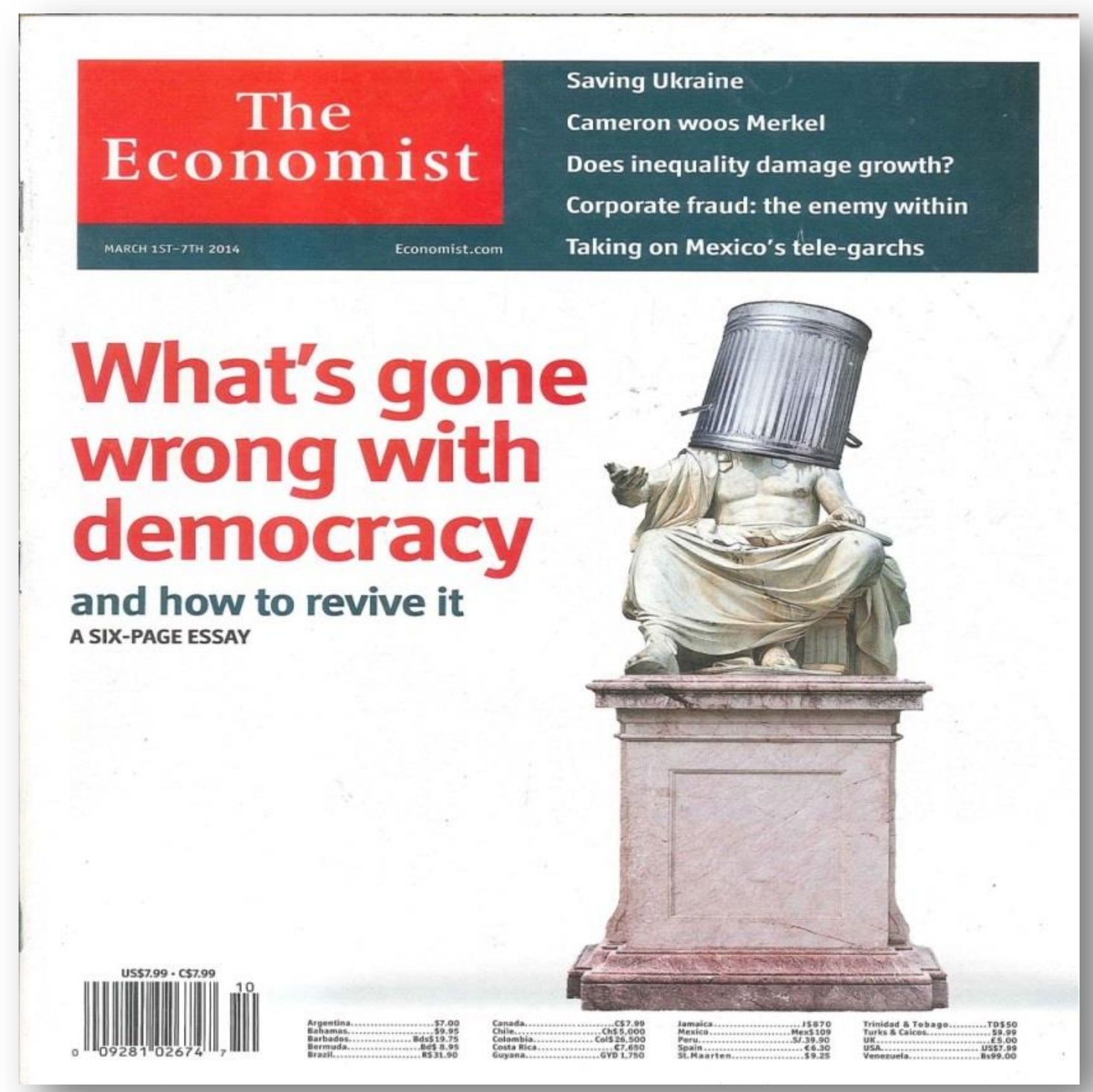

Fonte: The Economist, vol. 410, n. 8.876. 


\subsubsection{Contexto global e local}

O contexto global de produção da narrativa veiculada pela The Economist remete à globalização, processo que intensificou a transformação das relações sociais em várias extensões, especialmente a partir da segunda metade do século $X X$, e a emergência do capitalismo neoliberal que provocou alterações em vários níveis da vida humana.

O contexto global é de risco. Desde a esfera pública até a privada, em alguma medida, o ideal do progresso sofre um abalo. As inovações tecnológicas e organizacionais da sociedade já acarretaram efeitos negativos complexos, imprevisíveis e alguns deles incontroláveis. Qualquer tentativa de criar um novo sentido de coesão social tem de partir do reconhecimento de que o individualismo e o ceticismo estão inscritos na cultural ocidental. Isso aponta para o fato de que nenhum aspecto de nossas atividades segue um curso predestinado.

Nesse sentido, é preciso lembrar a expressão "sociedade de risco" de Ulric Beck (2010), a qual se refere a algo mais que o simples fato de que a vida social contemporânea introduz novas formas de perigo que a humanidade terá que enfrentar. As condições institucionais geradas pela individualização levam os indivíduos à perda dos direitos básicos exigindo um esforço de auto-organização e de controle maior para evitar que uma escolha errada afete irremediavelmente as suas vidas. Estamos assistindo a uma individualização dos conflitos. As exigências conflitantes impostas por um contexto de incerteza global tornam-se experimentais e arriscadas.

À medida que as condutas pessoais se relacionam com os problemas globais, surge o aspecto não institucional do político. Assim, o que parecia ser uma retirada para a vida privada representa a luta por uma nova política. Mas quando indivíduos começam a tomar conta do Estado e a dominar as arenas de discussão públicas, em que a ignorância é institucionalizada, a sociedade desgarra-se de seu consenso, suas estruturas ficam mais frágeis e mais sujeitas a processos de contestação das lutas coletivas. O que vemos, pois, na narrativa (Figura 61) é uma forma simbólica de oposição aos efeitos da luta democrática.

Nas democracias mais bem sucedidas, todos trabalharam para evitar a tentação do autoritarismo (FAIRCLOUGH e FAIRCLOUGH, 2012). Infelizmente, a noção de que ganhar uma eleição dá direito ao poder de fazer o que lhe interessa 
e agrada explica o problema cuja verdadeira solução está na restrição de interesses especiais e na limitação dos gastos que o Estado distribui. A narrativa focalizada representa a democracia como algo que tem peso, mas que é ineficiente nas condições da alta modernidade. Na realidade, a política, e não a democracia é que precisa de uma redefinição que ajude a criar uma consciência coletiva para que as mudanças sociais necessárias ocorram.

Ao contrário do que sugere o ensaio publicado em seis páginas interna da edição e para o qual a narrativa de capa da revista (Figura 61) aponta, este texto dissimula relações de poder que inibem possíveis manifestações políticas coletivas. Na realidade, a representação narrativa (Figura 61) contribui para reforçar a desilusão democrática em países da Europa, nos Estados Unidos e na Rússia, como pode ser observada por meio do quadro a seguir:

Quadro 17 - Desilusão democrática

Revista The Economist, 1 a 7 de março de 2014

\section{Democratic disillusion}

Voter turnout at parliamentary elections*

Selected countries, \% of voting-age population

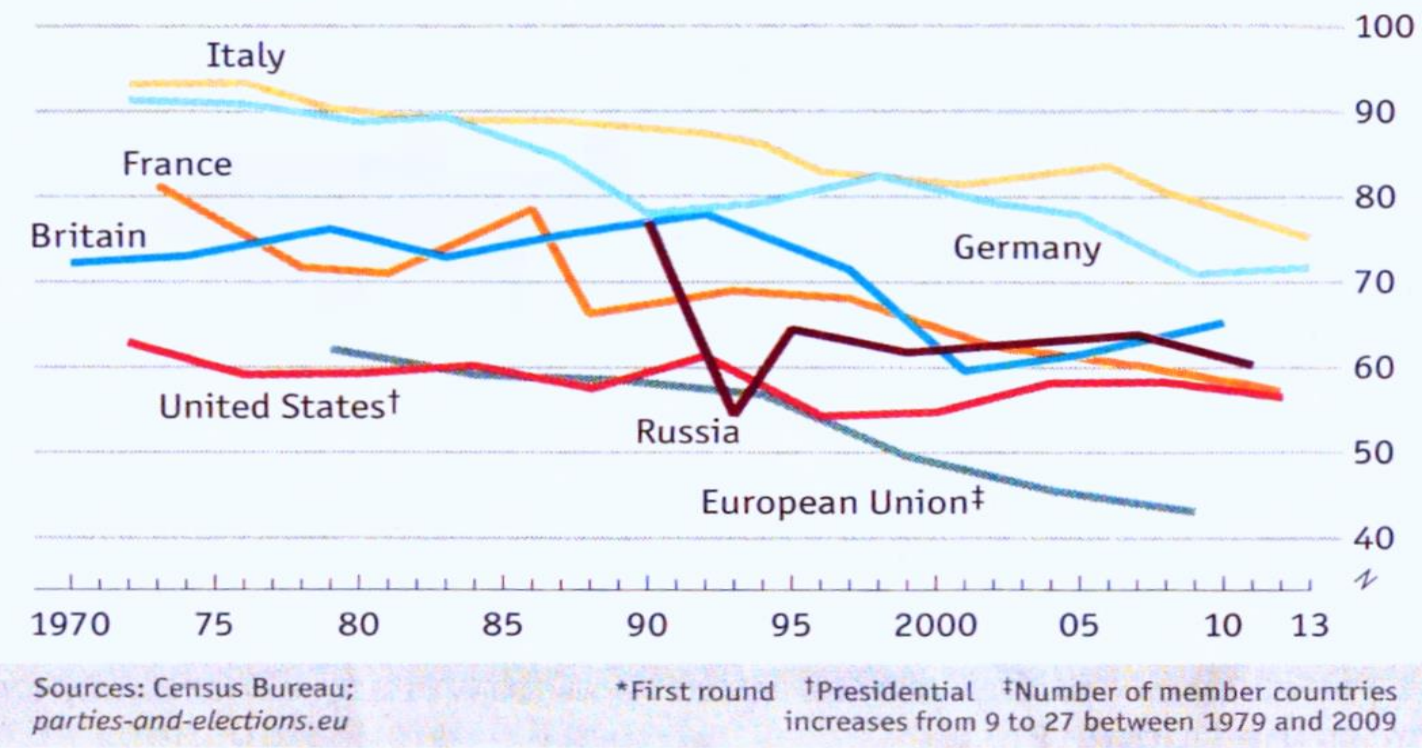

Fonte: The Economist, vol. 410, n. 8.876, p. 50. 
O quadro representa a desilusão dos eleitores nas últimas décadas, com relação aos seus parlamentares, gerada pelas promessas de campanha das últimas décadas e pela promoção fictícia de estabilidade.

Fairclough (2012, p. 30) explica que, em um modelo democrático, as preferências dos cidadãos não são apenas expressas, elas também se transformam, por meio de razões públicas, em um processo em que todos têm o direito de avançar, de responder ou de criticar propostas para solução de problemas. A democracia deliberativa, como ideal normativo de um regime, se justifica em razão da falibilidade humana. A participação realizada por meio de argumentos comprometidos com os valores democráticos faz com que as decisões, feitas por discussão entre os cidadãos livres, sejam legítimas e vinculativas.

Recursos como o conhecimento e a criatividade de um indivíduo são limitados, mas reunindo as suas capacidades limitadas, os indivíduos têm uma melhor chance de fazer uma boa decisão. Deliberar, ou discutir assuntos com os outros leva à superação do impacto da racionalidade limitada, pois deliberar, com os outros, revela que a informação é relevante para a escolha a ser feita, permitindo que as pessoas vejam as questões do ponto de vista de outras pessoas e incentivando um modo particular de justificar as reivindicações em termos do interesse público e do bem comum (FAIRCLOUGH, 2012).

Do exposto, compreendemos que o uso de forças e de ameaças está descartado. A única força que deve contar é a força do melhor argumento. Com efeito, a deliberação desenvolve virtudes cívicas e razões públicas, uma prática social que produz cidadãos melhores e mais informados e com um sentido de responsabilidade para ser compartilhado. Independentemente de quaisquer consequências, a deliberação é boa em si mesmo, pois produz decisões politicamente legítimas. Elas são legítimas, porque são o resultado de um processo justo, o que dá a todos o direito de avançar, de responder e de entender as razões públicas e não privadas. Mesmo aqueles que discordam do resultado verão que o resultado não foi arbitrário, mas justificável. Deliberação, portanto, tende a produzir resultados vistos como mais legítimos do que os produzidos por votação. Isto porque, por um lado, o raciocínio público tende a produzir um maior consenso. 
À medida que mais pessoas se convencem de que determinado resultado é bom, elas podem reformular suas preferências. Por outro lado, o incentivo a não expressar visão torna as pessoas mais inclinadas a discordar. A natureza cooperativa, mais que outros procedimentos autocráticos produzem as melhores respostas para os problemas.

Esta narrativa midiática (Figura 62) é um exemplo concreto de obstáculo para a viabilidade do modelo de democracia deliberativa. No texto há uma justaposição de conteúdos contraditórios. A imagem encaixada do lado direito da página, como informação nova, impacta porque evoca ideias antagônicas. Por um lado, remete à solidez da democracia, por outro lado, ao desprezo por ela.

\subsubsection{Contexto do evento social}

O texto de capa da revista The Economist traz a democracia como tema de natureza política que possui alto valor informacional, porque atualiza conhecimento de interesse amplo; entretanto, veicula significados que podem ser positivos para uns e negativos para outros. Positivos para as relações de poder e de dominação. Negativos, para as aspirações coletivas.

A narrativa chama a atenção do público leitor devido ao modo como a democracia é visualmente representada: uma lata de lixo de metal emborcada na cabeça de uma escultura neoclássica, apoiada por uma pesada base de mármore. A metáfora acessada pela capa da revista evoca o sentido de que o modelo democrático é estático, inerte, ultrapassado e ineficiente; senão, como um sistema que possui "cabeça dura", que, portanto, precisa ser severamente ajustado para funcionar.

É inegável que a imagem da capa revista inglesa The Economist, de certa forma, transmite uma informação de valor e de peso. A escultura que representa a democracia é sustentada por uma base sólida (mármore) que assegura essa conotação. Entretanto, na medida em ela porta uma lata de lixo sobre a sua cabeça, o seu significado é violentamente transformado.

Os atributos da democracia são a racionalidade, a imparcialidade e a liberdade. Nessa quase interação mediada pela mídia, porém, a racionalidade é 
representada como algo descartável, como algo (lixo) que confronta os indivíduos porque despreza um valor amplamente considerado pela humanidade.

O texto remete à leitura do ensaio ${ }^{35}$ intitulado What's gone wrong with democracy, o qual oferece conhecimentos sócio-históricos que permitem ao público leitor atribuir significados reais à democracia. $\mathrm{O}$ ensaio refere-se à ao modelo político como a ideia de maior sucesso no século $X$, que agora passa por momentos críticos; mas que apesar disso, a democracia é o motiva as pessoas a ir às praças principais participar de protestos contra as forças que moldam o seu futuro e o de seus filhos, fato que testemunha a importância do Estado-Nação democrático e a sua vitalidade.

Contribui para reforçar esse ponto de vista a imagem relacionada ao ensaio, a qual pode ser visualizada para melhor entendimento da análise da narrativa veiculada na capa da revista:

Figura 62 - Ideal democrático

Revista The Economist, 1 de março de 2014

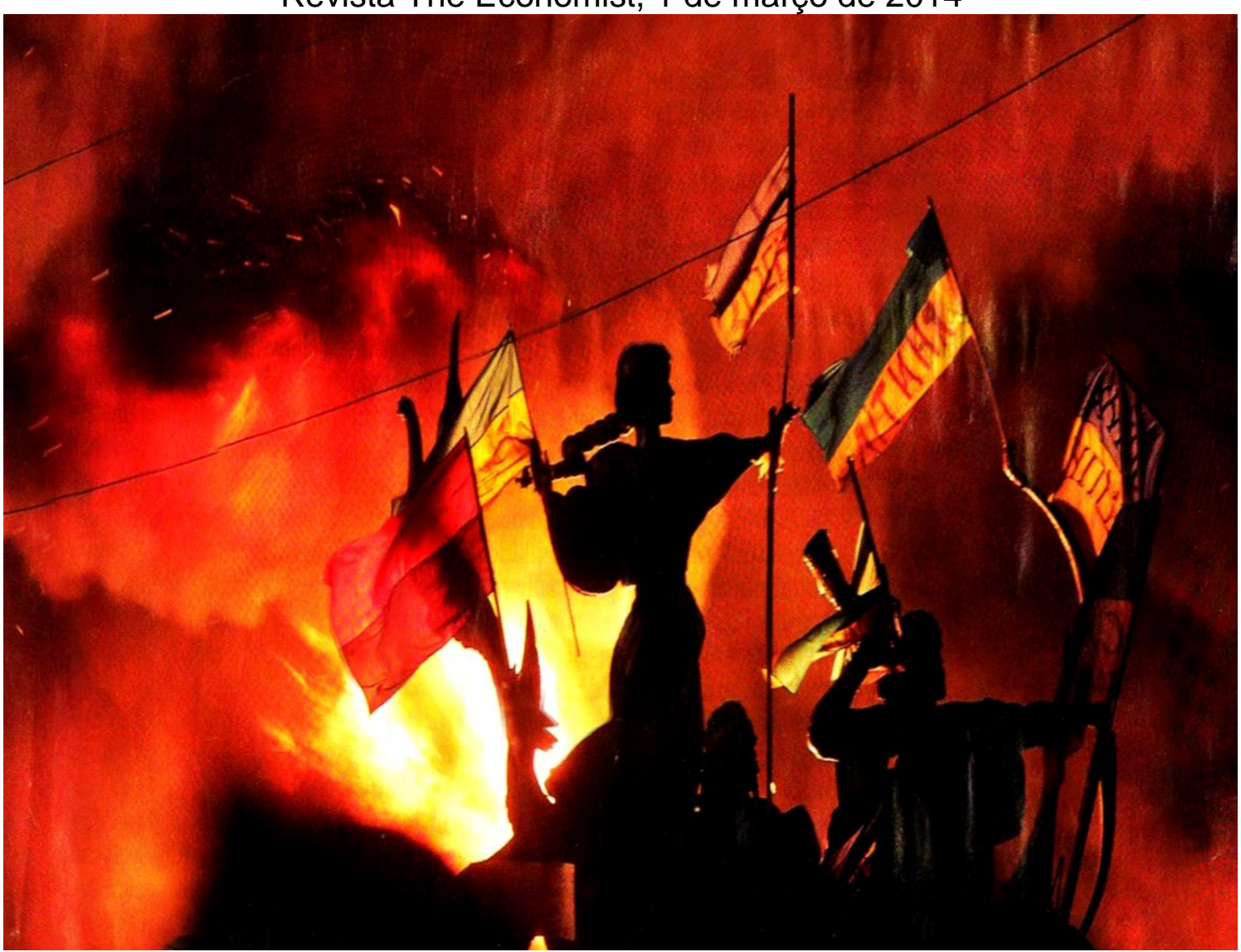

Fonte: The Economist, vol. 410, n. 8.876, p. 47.

${ }^{35}$ Uma versão interativa desse ensaio pode ser acessada pelo site: economist.com/democracy. 
Modalizada pela cor preta e pelo vermelho saturado, a narrativa (Figura 63) representa a democracia como uma expressão revolucionária, pungente e envolvente. $\mathrm{O}$ significado desse texto contrasta com o significado projetado pelo texto de capa da revista (Figura 62) que focaliza a democracia de modo desarticulado sobre o pano de fundo liso, vazio de baixa modalidade. Enquanto aquele atribui valor à luta democrática realizada no passado, este nega a existência de esforços presentes voltados para um fim cooperativo.

O ensaio expõe que as democracias são menos propensas a ir à guerra, mas que, mesmo as democracias mais estabelecidas, apresentam falhas que levam a conflitos inevitáveis e que, quando um país democrático se encontra em um estado de crise, ou seja, tão ruim quanto era antes, a autocracia acaba por ser muito mais fácil do que a criação de um governo democrático viável.

Após opor-se à declaração de John Adams, ex-presidente da América, para quem a democracia não durava muito tempo porque se exauria e suicidavase, o texto de divulgação científica destaca que, o que minou a confiança nos sistemas políticos ocidentais foi a crise financeira e a ascensão da China, pois ambas revelaram as debilidades fundamentais dos sistemas democráticos. Apesar disso, a democracia é inerentemente superior e acabará por prevalecer. Ao comparar a democracia com os avanços impressionantes da China, destaca o texto que o país socialista esconde problemas mais profundos.

Há um viés político no ensaio para o qual o texto de capa da revista The Economist, consonante com o ponto de vista persuasivo da narrativa, qual seja: 0 de que democracia perdeu o seu impulso e a vitalidade. Mas, o texto justifica que o problema decorre do crescimento do tamanho do Estado, das promessas políticas em momentos de eleições e que depois não podem ser asseguradas.

Em sua conclusão, o ensaio menciona a importância do controle da política monetária dos bancos centrais independentes, porque foi o que domou a inflação galopante dos anos 1980. O texto, por fim, chama a atenção para a necessidade de se aplicar o princípio do governo limitado a um vasto leque de políticas, pois "democracias maduras, assim como as nascentes exigem controles e equilíbrios". De um modo geral, podemos dizer que a perspectiva do ensaio é 
distinta daquela evocada pela representação narrativa publicado na capa da edição da The Economist, de maio de 2012, vol. 410, n. 8.876 .

5.3.1.1.1 Análise do Texto C

Figura 63 - Democracia

Revista The Economist, 1 de março de 2014

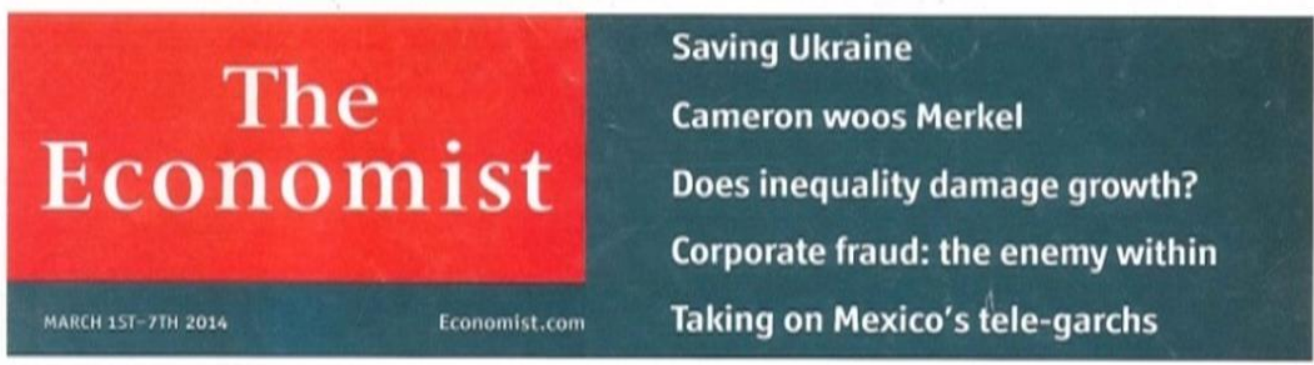

\section{What's gone wrong with democracy} and how to revive it A SIX-PAGE ESSAY

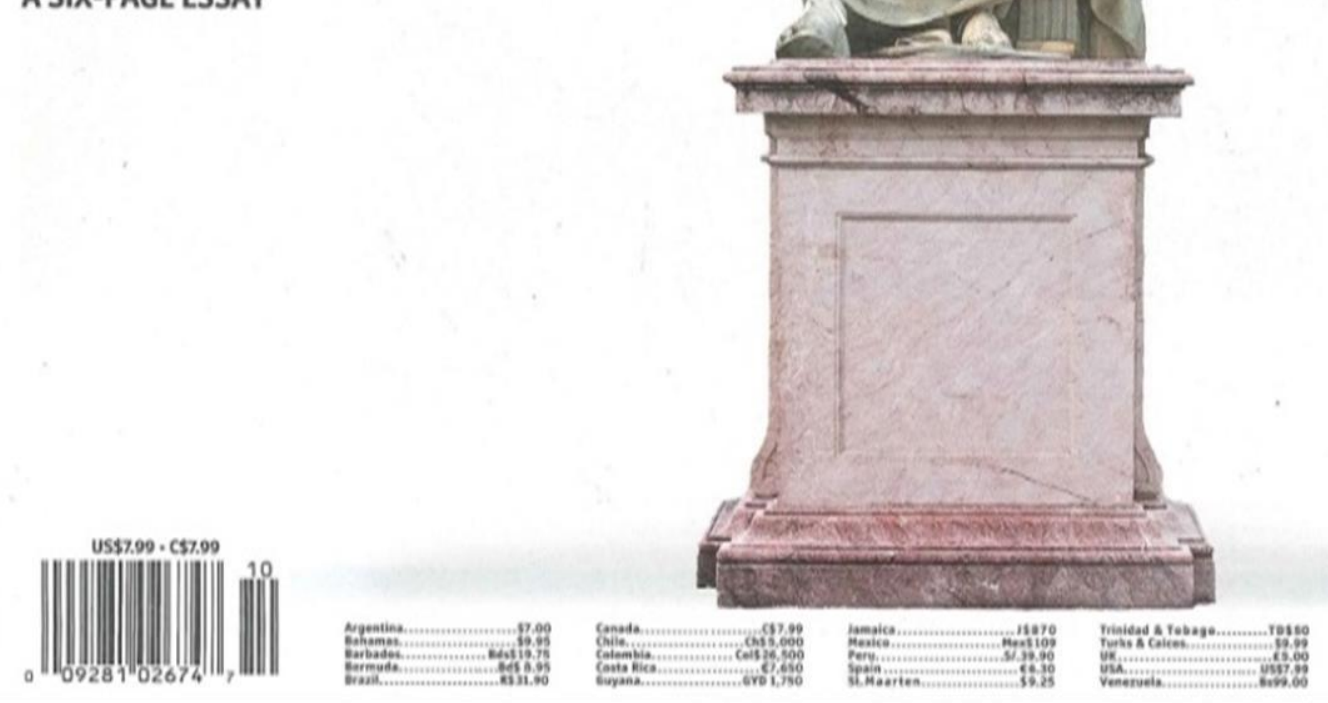

Fonte: The Economist, vol. 410, n. 8.876, p. 47. 


\subsection{Gênero global e local}

A narrativa de capa da revista The Economist é um gênero de texto desencaixado organizado pela escrita e imagem em um formato tecnológico capaz de transcender redes de comunicação em diferentes escalas (FAIRCLOUGH, 2003). Do ponto de vista da Mutlimodalidade, a narrativa é um gênero de texto com característica de gênero global, do tipo problema-solução (MACHIN e VAN LEEUWEN, 2007)

Discursivamente, o problema é expresso pela informação disposta no lado esquerdo da página: Whats's gone wrong with democracy (o que há de errado com a democracia?) e, visualmente, por meio do modo de representação da democracia, disposto no centro direito da página: escultura clássica em cuja cabeça uma lata de lixo aparece emborcada. A solução, por sua vez, é discursivamente expressa pela informação verbal and how to revive it $\boldsymbol{A}$ SIXPAGE ESSAY (e como reavivá-la UM ENSAIO DE SEIS PÁGINAS) e, visualmente, por meio da metáfora visual: gesto da mão direita da escultura, entendido aqui como um convite à leitura do texto que aparece sobre o colo da escultura e para o qual a mão esquerda aponta.

A obra plástica representativa da Democracia, apoiada por base de mármore, tem peso e alto valor informacional, mas o que atrai a atenção do público leitor é o modo de focalização do problema. A lata de lixo por sobre a cabeça da escultura reduz o regime democrático a algo descartável. $\mathrm{O}$ desprezo pela racionalidade é um mecanismo que suprime do dispositivo político a argumentatividade, qualidade da exposição lógica e plausível de um conjunto de ideias compartilhadas coletivamente. A supressão da capacidade de exercer a própria razão e elimina o caráter do que é inteligível e racional.

A narrativa midiática impacta e chama a atenção do público leitor para a aquisição da revista, mas o conteúdo do ensaio para o qual a imagem aponta contradiz o sentido veiculado. Por isso, o gênero pode não ser bem tão bem sucedido, quanto os gêneros (globais) que promulgam e perpetuam relações de poder e de dominação. 


\subsection{Representação narrativa}

Este texto representa um evento. O vetor do processo narrativo não transacional que estrutura essa representação multimodal é a mão que emana do participante ator representado. O participante tem peso, valor informativo, foco e saliência, mas seu significado é modificado por circunstância de acompanhamento (a lata de lixo). A narrativa acessada por metáfora, um modo típico da ideologia que fragmenta relações sociais ao deslocar um objeto de outro campo semântico que não poderia ser aplicado ao contexto de evento, porque ameaça a soberania popular, ignora a argumentação coletiva e a liberdade de comunicar.

Os significados dessa narrativa ameaçam a liberdade de expressão construindo a realidade com valores que influem poderosamente na construção da identidade cultural e, portanto, refletem o poderio das corporações que exercem influência sobre as práticas da mídia, fazendo com que essas dificilmente possam ser consideradas democráticas.

\subsection{Modalidade}

De acordo com a orientação naturalista, o evento visualmente representado é descontextualizado. Seu plano de fundo é liso, não modelado, vazio e desarticulado, mas, como o participante ator representado é ligado ao tempo presente e modalizado com nitidez de detalhes, a imagem sugere uma percepção geral da democracia. Sombras são abstraídas do conjunto da imagem, porém dois sutis sombreamentos podem ser observados: um no coração da escultura e outro sob a base que sustenta a obra plástica. O primeiro sombreamento marca os resíduos provenientes da lata de lixo e o outro separa delimita o espaço inferior do texto multimodal.

A análise semiótica crítica da narrativa política mostra como, em determinadas circunstâncias, a produção jornalística sob o controle de conglomerados globais deixa de desempenhar o seu papel e passa a reproduzir um discurso cada vez mais ideológico. Isso mostra que ainda que se tornem alvo de crítica, as relações de dominação operam por meio de formas simbólicas de 
alto risco. Contudo, o papel da deliberação nas sociedades ocidentais tornou-se crucial, pois estamos contemplando uma variedade de considerações relevantes e ideais que pesam em Estados-Nação democráticos.

Acreditamos que se a narrativa de capa da The Economist suprimisse 0 argumento prático (a inserção da lata de lixo sobre a cabeça da escultura clássica) do gênero desencaixado, significados da forma de ação e de interação motivariam a reflexividade, a valorização da deliberação, como forma legítima da Democracia. De outro modo, o gênero promoveria valores verdadeiramente democráticos: a racionalidade, a imparcialidade e a liberdade de expressão, algo essencial ao exercício pleno e dignificante da mídia global.

\subsection{Ideologia e efeitos sociais da narrativa}

A utilização dessa mesma estrutura multimodal gera efeitos de sentido que podem inibir as ações políticas tanto quanto incentivá-las. Todavia, a fragmentação de um modelo político que permite a todos iguais oportunidades de opinar de modo colaborativo, possivelmente, gerará efeitos sociais negativos de longo prazo.

As manifestações populares ocorridas em Estados-Nação democráticos podem gerar situações de risco, sim. Mas, certamente, a coerção simbólica, eficiente arma ideológica contra reações legítimas oriundas da liberdade de expressão, que, de forma sutil e imperceptível, coloca as sociedades em situação de constante vigilância. Um estado que contribui para o enfraquecimento das relações sociais ameaça, ainda mais, a integridade e a soberania do EstadoNação.

Onde os pontos de vista podem ser expressos e pressupostos como eficazes para alguns, há ações favoráveis ou não. Isso faz parte das práticas sociocomunicativas. Todavia, em espaços onde a expressão argumentativa distinta não tem lugar, predominam as reações contrárias, na maioria das vezes, irrefletidas. 
As análises aqui concretizadas apontam para a necessidade da intermediação de uma ética responsável que contribua para a ampliação e o aprofundamento consciente da reflexão crítica sobre o uso social da palavra e da imagem que transcende redes de comunicação e escalas. Uma vez expressa, impressa e reimpressa em escala global, a narrativa midiática pode fortalecer ou enfraquecer a sociedade, gerando a estabilidade ou a instabilidade social e, consequentemente, à própria atividade sociocomunicativa. Decisões serão sempre mais razoáveis quando resultarem da racionalidade coletiva, mesmo que, em determinadas circunstâncias, a opinião pública possa ser manipulada à crença de que não. 


\section{CONCLUSÕES}

Orientada com base no triângulo discurso - cognição - sociedade, nossa pesquisa qualitativa interpretativa defende a tese de que as narrativas midiáticas multimodais de alto consumo são um gênero de texto produzido sob o controle de modelos de contextos globais e locais persuasivos, em cujo formato tecnológico os elementos são representados e modalizados de modo a produzir efeitos de sentido sobre as condutas sociais. Portanto, não são (re)produções fiéis da realidade como é do senso comum.

A defesa da tese aprofunda o conhecimento em torno dos contextos globais (VAN DIJK, 2011) que exercem influência sobre a prática social da mídia contemporânea, da qual as semioses políticas são partes relevantes (FAIRCLOUGH, 2006), e amplia a visão acerca dos contextos locais tratados aqui como modelos sócio-históricos, que mantêm a prática dos meios de comunicação em funcionamento ao longo dos tempos, e como modelos institucionais (as revistas), que fazem circular os bens informativos para o consumo da sociedade (THOMPSON, 2011).

A defesa de nossa proposição apoia-se em uma fundamentação teórica multidisciplinar originada de teorias consistentes e confiáveis e em uma triangulação de conhecimentos distintos - linguístico, cognitivo e social -, mas dialeticamente relacionados, bem como demanda a explicitação de categorias analíticas sistematizadas pelas teorias abordadas, as quais são aplicadas aos dados semióticos extraídos de uma amostra constituída de primeiras páginas de jornais e de capas de revistas de notícias.

As análises críticas semióticas de quatro narrativas midiáticas multimodais transparecem os contextos envolvidos na produção do gênero, bem como os modos de construção dessas formas de ação, de representação e de identificação e os sentidos ideológicos que elas evocam. 
Em resposta à primeira questão (como as narrativas midiáticas multimodais difundidas pela mídia global são estrategicamente organizadas?), as análises da categoria gênero discursivo e gênero global revelam que:

- as narrativas midiáticas multimodais são formas de (inter)ação mais ou menos abstratas, organizadas em formatos tecnológicos capazes de transcender redes de comunicação particulares em diferentes escalas;

- as narrativas mediadas pela mídia global aparecem fragmentadas e organizadas em sequências diferentes da ordem lógica e cronológica dos relatos originais sobre os eventos;

- as narrativas jornalísticas impressas de alto consumo são produtos informativos congruentes com os bens circulantes do mercado global consumidor;

- as narrativas multimodais recontextualizadas como gêneros de governança visam promover imagens de políticos de grupos sociais com finalidades específicas e particulares;

- as narrativas midiáticas multimodais são um gênero global composto com recursos dos modos da linguagem utilizados para promulgar e perpetuar relações de poder e de dominação;

- as narrativas midiáticas multimodais focalizam mais os problemas que as solução, de maneira que os efeitos de sentidos das formas multimodais manipuladas tornam possível a produção e a difusão continuada do tema coberto pela mídia;

- as narrativas incorporam argumentos persuasivos capazes de neutralizar os efeitos das lutas sociais, de restabelecer o poder legitimamente constituído e de retomar o controle sobre as ações e as reações massivas. 
Em resposta à segunda questão (de que modo os participantes das estruturas narrativas midiáticas são representados para ter efeitos sociais?), as análises da categoria representação narrativa demonstram que:

- os eventos culturais de domínio público são organizados por processos de ação não transacionais que ativam conhecimentos amplamente valorizados para fortalecer a legitimidade do poder político constituído;

- eventos culturais de domínio público podem ser recontextualizados, com relativa facilidade, por práticas empresariais para que interesses econômicos corporativos sejam atendidos;

- os participantes atores das estruturas narrativas da mídia, em certas circunstâncias, são estrategicamente representados, conforme os interesses hegemônicos - ou são representados por meio de formas que os legitimam ou de forma que convívio social;

- os participantes secundários de estruturas narrativas ideológicas, não alteram as proposições, mas podem ser relacionados aos participantes representados nas estruturas, por intermédio do uso estratégico de recursos semióticos com o propósito de neutralizar os efeitos gerados por circunstâncias que ameaçam o poder;

- as representações narrativas incorporam modos estratégicos da ideologia planejados para o exercício do controle social pelo Estado;

- as narrativas midiática multimodais podem ter efeitos sociais modeladores das ações sociais que poder ser positivos, mas também negativos e contrários à ordem sociopolítica e econômica. 
E com relação à terceira (como são modalizadas as narrativas ideológicas manipuladas pela mídia impressa?), as análises da categoria modalidade evidenciam que:

- o uso de marcadores de modalidade nas formas jornalísticas estetizadas podem abrir questões de verdade sobre a relação entre a história original e a história narrada;

- a modalização de elementos, como os participantes das representação narrativas, assegura os efeitos de sentido determinados pelos modelos de contexto que incidem sobre a prática de produção e de difusão do gênero;

- a recontextualização de eventos de domínio público por práticas do domínio privado, na forma do gênero de governança visa satisfazer interesses corporativos;

- as narrativas midiáticas multimodais são modalizadas com o uso de recursos semióticos como: o tamanho dos participantes atores, a colocação dos elementos no design, sobreposição de planos, saturação, diferenciação modulação da cor etc.;

- as narrativas modalizadas sob a perspectiva de ângulos elevados e envolventes evocam pontos de vista particulares sobre acontecimentos do mundo social;

- os significados das narrativas multimodais ideológicas produzidos com o uso de marcadores de modalidade neutralizam efeitos resultantes das lutas sociais. 
Como vimos, as análises semióticas críticas dos textos demostram que, a mídia global age sob o controle de modelos globalistas, de modelos capitalistas e de modelos de gestão exclusivistas. Para isso, revistas de alcance global e de alto consumo são usadas como chaves altamente eficientes. Isso, em parte, se deve ao gênero de mídia ao qual a sociedade confere maior credibilidade e valor capital.

Sabemos que a sociedade é inseparável da linguagem e, por conseguinte, da mídia, porque toda experiência social é mediada. As narrativas midiáticas analisadas saem da sociedade e voltam para ela. Isso não implica que o gênero acessado nas redes globais sejam espelhos da realidade seja desnudado de falsas crenças. O problema maior é que nas condições da alta modernidade as narrativas jornalísticas tornaram-se formas de comunicação hiper-reais que facilmente se infiltram na consciência cotidiana, produzindo sentidos que aumentam o individualismo e o ceticismo.

O papel social dos meios de comunicação é o de informar sobre o que acontece no mundo sócio-político-econômico segundo fontes legitimadas pela própria mídia. Mas a representação da realidade sob o domínio de interesses corporativos sucede à manutenção de problemas aparentemente insolucionáveis. O uso da linguagem envolvente, típico das narrativas ficcionais, cujos tropos garantem efeitos estéticos no gênero jornalístico, em que a objetividade e a factualidade são as características que garantem efeito de veracidade, suprime desse gênero o atributo conferido pela linguagem referencial.

Acreditamos que a valorização da informação midiática residirá, não necessariamente na estética atraente dos modos que caracterizam as narrativas ficcionais, não no impacto dos sentidos de suas metáforas, tão pouco na homogeneidade de seus formatos e arranjos tecnológicos, mas nos testemunhos originais como fonte para a expressão midiática de verdades plausíveis da realidade.

Cabe dizer que uma das limitações de nossa pesquisa social deve-se à exiguidade de estudos e de análises sociossemióticas e sociocomunicativas preocupadas com os efeitos sociais dos gêneros midiáticos. Aliás, um campo em que as teorias enfrentam dificuldades é o campo da comunicação social, porque os 
fatos representados sob a influência da mídia política, cujo principal material de trabalho é a credibilidade, correm muito mais velozes que as teorias.

Esperamos que a pesquisa contribua para ampliar a reflexão crítica acerca da influência que os modelos de contextos hegemônicos exercem sobre as práticas sociocomunicativas da mídia global e para aprofundar as análises dos modos de construção dos gêneros midiáticos multimodais, produzidos mediante a ativação de mecanismos que administram a informação e de estratégias que operacionalizam ideologia a fim de mais satisfazer o poder e a dominação. Esperamos, por fim, que este estudo multidisciplinar possa motivar a produção de pesquisas que desenvolvam e ampliem a percepção sobre os efeitos sociais produzidos pelos gêneros midiáticos globais. 
AZEVEDO. A. O que é design. São Paulo: Brasiliense, 2008.

BAL, M. Narratology: introduction to the theory of narrative. London: University Toronto Press, 2009.

BALDRY, A; THIBAULT, P.J. Multimodal transcription and text analysis: a multimedia toolkit and coursebook with associated on-line couse. London: Equinox, 2006.

BAKHTIN, M. Estética da criação verbal. São Paulo: Martins Fontes, 1997.

. Marxismo e filosofia da linguagem. São Paulo: Hucitec, 1997.

BAUMAN, Z. Globalização: as consequências humanas. Rio de Janeiro: Jorge Zahar, 1999.

. Em busca da Política. Rio de Janeiro: Jorge Zahar, 2001.

. Vida para Consumo. Rio de Janeiro: Jorge Zahar, 2008.

BAUER, M. W.; GASKELL, G. Pesquisa qualitativa com texto, imagem e som: um manual prático. Petrópolis, Rio de Janeiro: Vozes, 2005.

BAZERMAN, C. Gêneros textuais, tipificação e interação. São Paulo: Cortez, 2005.

BECK, U. Sociedade de risco: rumo a uma outra modernidade. Trad. Sebastião Nascimento. São Paulo: Editora 34, 2010.

BRONCKART, J. P. Atividade de linguagem, textos e discursos. São Paulo: Educ., 1999. 
BOURDIEU, P. Poder simbólico. Trad. Fernando Tomaz. 6. ed. Rio de Janeiro: Bertand Brasil, 2003.

. Las estratégias de la reproducción social. Buenos Aires: Siglo Veintiuno, 2011.

CASTELLS, M. A. Sociedade em rede. Lisboa: Fundação Calouste Gulbenkian, 2002.

. Communication power. New York: Oxford University Press, 2009.

CHOULIARAKI, L.; FAIRCLOUGH, N. Discourse in late modernity: rethinking critical discourse analysis. Edinburg: Edinburg University Press, 1999.

CORRÊA, M.L.G. Linguagem e Comunicação Social: visões da linguística moderna. São Paulo: Parábola, 2002.

CUNHA, M.A.F; SOUZA M.M. Transitividade e seus contextos de uso. Rio de Janeiro: Lucerna, 2007.

DENZIN, N. K.; LINCOLN, Y. S. O planejamento da pesquisa qualitativa: teorias e abordagens. Trad. Sandra Regina Netz. Porto Alegre: Artmed, 2010.

DICIONÁRIO Inglês-Português. Acordo Ortográfico. Portugal: Porto Editora. 2010.

EMEDIATO, W. (Org.). A construção da opinião da mídia. Belo Horizonte: NAD, 2013.

FAIRCLOUGH, N. Language and power. London: Longman, 1989.

Media Discourse: voices. London: Edward Arnould, 1995.

Discurso e mudança social. Coord., trad., rev. técnica e prefácio Izabel Magalhães. Brasília: Editora Universidade de Brasília, 2001. 
. Analysing discourse: textual analysis for social research. London: Routledge, 2003.

- Critical Discourse Analysis: the critical study of language. 2. ed. London: Pearson, 2010. . Language and globalization. London; New York: Longman, 1996.

FAIRCLOUGH, I.; FAIRCLOUGH, N. Political discourse analysis: a method for advanced students. London and New York: Routledge, Taylor \& Francis Group, 2012.

FLICK, U. Uma introdução à pesquisa qualitativa. Trad. Sandra Regina Netz. 2. ed. Porto Alegre: Bookman, 2004.

FOWLER, R. Language in the news: discourse and Ideology in the press. London and New York: Routledge, 1991.

FOUCAULT, M. A arqueologia do saber. Trad. Luiz Felipe Baeta. 7 ed. Rio de Forense: Forense Universitária, 2004.

A ordem do discurso. São Paulo: Loyola, 2004.

FUZER, C.; CABRAL, S. R. S. Introdução à Gramática Sistêmico-Funcional em Língua Portuguesa. Rio Grande do Sul: Universidade de Santa Maria, 2010.

GARCEZ, L. H. C. A escrita e o Outro. Brasília: Editora UnB, 1998. . Técnica de Redação. São Paulo: Martins Fontes, 2001.

GENETTE, G. Narrative discourse. Oxford: Blackwell, 1972.

GROS, F. Foucault: a coragem da verdade. São Paulo: Parábola, 2004. 
GIDDENS, A. As consequências da modernidade. Trad. Raul Fiker. São Paulo: Unesp, 1991.

. Modernidade e identidade. Rio de Janeiro: Jorge Zahar, 1999.

. Mundo em descontrole: o que a globalização está fazendo de nós. Rio de Janeiro: Jorge Editor, 2002.

HALL, S. A identidade cultural na pós-modernidade. São Paulo: DP\& A, 2005.

HALLIDAY, M. A. K. An introduction to funcional grammar. London: Arnold, 1994.

Language, context and text: aspects of social language in a semiotic perspective. Oxford: Oxford University Press. 1989.

. Language as social semiotic: the social interpretation of language and meaning. London, New York, Melbourne, Auckland: Edward Arnold, 1978.

HALLIDAY, M. A. K.; MATTHIESSEN, C. An introduction to functional grammar. London: Edward Arnold, 2004.

HOUAISS, A. Dicionário da Língua Portuguesa. Rio de Janeiro: Objetiva, 2001.

ILARI, R. Introdução à Semântica. Brincando com a Gramática. São Paulo: Contexto, 2006.

JEWITT, C. The routledge handbook of multimodal analysis. London and New York: Routledge, 2011.

KOCK, I. V. O texto e a construção dos sentidos. São Paulo: Contexto, 2005.

KRESS, G. Multimodality: a social semiotic approach to contemporary communication. London and New York: Routledge, 2010. 
KRESS, G.; VAN LEEUWEN, T. Multimodal discourse: the modes and media of contemporary communication. New York: Oxford Press, 2001.

. Reading images: the grammar of visual design. London: Routledge, 2006.

LIMA, V. A. Mídia: crise política e poder no Brasil. São Paulo: Fundação Perseu Abramo, 2006.

MAGALHÃES, I. A critical discourse analysis of gender relations in Brazil. Journal of Pragmatics, 23, p. 183-197, 1995.

MACHIN, D.; VAN LEEUWEN, T. Global media discourse: a critical introduction. London and New York: Routledge, 2007.

MARCUSCHI, L. A. Produção textual, análise de gêneros e compreensão. São Paulo: Parábola Editorial, 2008.

MACLUHAN, M.. Os meios de comunicação como extensões do homem. Trad. Décio Pignatari. 18. Ed., São Paulo: Pensamento - Cultrix Ltda, 2012.

MCQUAIL, D. Teorias da Comunicação de Massa. Trad. Roberto Cataldo Costa. Porto Alegre: Penso, 2013.

MORAN, E. Saberes Globais e Saberes Locais: o olhar transdisciplinar. Rio de Janeiro: Garamond, 2001.

MOTTA, L. G. Análise crítica da narrativa. Brasília: UnB, 2013.

MUSSALIM, F.; BENTES, A. C. Introdução à lingüística: domínios e fronteiras. São Paulo: Cortez, 2004.

ORLANDI, E. P. Discurso e Texto. Formulação dos Sentidos. Campinas: Pontes, 2008. 
PAGE, R. New perspective on narrative and multimodality. London: Routledge, 2011.

PEDRO, E. R. (Org.). Análise Crítica do Discurso. Lisboa: Caminho, 1998.

PINTO, J. P.; FABRÍCIO, B. F. (Orgs.). Exclusão social e microrresistências a centralidade das práticas discursivo-identitárias. Goiânia: Cânone editorial, 2013.

RAJAGOPALAN, K. Por uma lingüística crítica: linguagem, identidade e a questão ética. 2. ed. São Paulo: Parábola, 2003.

RAMALHO, V.; RESENDE, V. O texto como material de pesquisa. Campinas, SP: Pontes, 2011.

RICHARDSON, J. E. Analysing newspapers: an approach from critical discourse analysis. New York: Palgrave Macmillan, 2007.

ROCHA, H. Um novo paradigma de revisão de texto: discurso, gênero e multimodalidade. Tese de doutorado. Brasília: PPGL, UnB, 2012.

RODRIGUES, C. Jornalismo on-line: modos de fazer. Rio de Janeiro: Sulina, 2009.

RUSSI, P. Processos semióticos em comunicação (Org.). Brasília: Editora UnB, 2013.

SATO, D. T. B.; BATISTA, J. R. L. (Orgs.). Contribuições da Análise de Discurso Crítica no Brasil: uma homenagem à Izabel Magalhães. São Paulo: Pontes, Linguagem e Sociedade, v. 5, 2013.

SAUSSURE, F. Curso de lingüística geral. São Paulo: Cultrix, 1975.

SGNORINI. I. (Org.) [Re]Discutir texto, gênero e discurso. São Paulo: Parábola, 2008. 
SILVA. F. C. O. A construção social de identidades étnico-raciais: uma análise discursiva crítica do racismo no Brasil. Tese de doutorado. Brasília: PPGL, UnB, 2009.

SILVA, D. E. G. (Org.). Nas instâncias do discurso: uma permeabilidade de fronteiras. Brasília: Universidade de Brasília/Oficina Editorial do Instituto de Letras/Editora Plano, 2005.

. Língua, gramática e discurso. Goiânia: Cânone Editorial, 2006.

SILVA, D. E. G.; VIEIRA; J. A. (Orgs.). Análise de Discurso: percursos teóricos metodológicos. Brasília: Universidade de Brasília/Oficina Editorial do Instituto de Letras/Editora Plano, 2002.

SILVA, D. E. G. et al. (Orgs.). Discurso em questão: representação, gênero, identidade, discriminação. Goiânia: Cânone Editorial, 2009.

SILVERSTONE, R. Por que estudar a mídia? São Paulo: Edições Loyolas, 2011.

SOARES, N.M.M. Discurso verde: reposicionamento das marcas. Tese de doutorado. Brasília, UnB, 2013.

THOMPSON, J. B. Ideologia e cultura moderna: teoria social crítica na era dos meios de comunicação de massa. Petrópolis:Vozes, 2011.

. A mídia e a modernidade: uma teoria social da mídia. Petrópolis: Vozes, 2012.

VAN DIJK, T. Racismo y discurso de las elites. Barcelona: Gedisa, Editorial, 2003.

. Discurso e poder. São Paulo: Contexto, 2008.

. Discurso e Contexto: uma abordagem sociocognitiva. Trad. Rodolfo Ilari. São Paulo: Contexto, 2011. 
. New Analysis: case studies of international and matinal News in the press. New York and London: Routledge, 2011.

VAN LEEUWEN, T. Introducing social semiotics. London: Routledge, 2005.

. Discourse and Practice: new tools for critical discourse analysis. Oxford: University Press, 2008.

. The language of colour: an introduction. London and New York: Routledge, 2011.

VIEIRA, J. A. Novas perspectivas para o texto: uma visão multissemiótica. In: VIEIRA, J. A. et al. Reflexões sobre a Língua Portuguesa: uma abordagem multimodal. Petrópolis, Rio de Janeiro: Vozes, 2007.

VIEIRA, J. A.; SILVA, D. E. G. (Orgs.). Práticas de Análise do Discurso. Brasília: Universidade de Brasília/Oficina Editorial do Instituto de Letras: Editora Plano, 2003.

VIEIRA, J. A. et al. (Orgs.). Olhares em Análise de Discurso Crítica. Brasília: Cepadic, 2009.

WODAk, R.; MEYER, M. Métodos de analysis critico del discurso. Barcelona: Gedisa Editorial, 2003.

WODAK, R.; RICHARDSON J. E. Analysing fascist discourse: European fascism in talk and text. London: Routledge, 2012. 


\section{Revistas consultadas}

GUARESCHI, P. A. Mídia e democracia: o quarto versus o quinto poder. In: Revista Debates. Porto Alegre, v. 1, n. 1, p. 6-25, jul-dez.2007.

VIEIRA, J. A. A contribuição do letramento muiltmodal para os multiletramentos. In: Linguagem em Foco. Revista do Programa de Pós-Graduação em Linguística Aplicada da Universidade Estadual do Ceará. Fortaleza: EDUECE, v. 2, n. 2, 2010.

VIEIRA, J. A.; BENTO, A. L. (Orgs.). Discursos Contemporâneos em Estudo. Revista do Centro de Pesquisas em Análise de Discurso Crítica. Brasília: UnB/Cepadic, v. 1, n. 1, 2011.

VIEIRA, J. A. et al. (Orgs.). Discursos Contemporâneos em Estudo. Revista do Centro de Pesquisas em Análise de Discurso Crítica. Brasília: UnB/Cepadic, v. 2, n. $2,2014$.

VIEIRA, J. A.; FERRAZ, J. A. Percursos e avanços do texto multimodal: novas perspectivas na contemporaneidade. Revistas Discursos Contemporâneos em Estudo, Brasília, v. 1, n.1, p. 9-23, 2011. 


\section{Sites consultados}

$<$ http://www.agenciabrasil.ebc.com.br>.

<http:www.estadão.com.br>.

$<$ http:www.oglobo.com.br>.

$<$ http://www.fotolia.com/banco-imagens.com.br>.

$<$ http://www.google.com.br/search?q=revista $>$.

$<$ http://www.guiadacarreira.com.br>.

$<h t t p / / w w w . g 1 . c o m . b r>$.

<http://www.observatoriodaimprensa.com.br/news/view>.

<http://professorfaustosimoes.blogspot.com.br/2013/03/globalizacao.html>.

$<$ http://www.senado.gov.br/noticias/especiais/brasilia50anos/not02.asp>.

$<$ http://super.abril.com.br/blogs/superlistas/as-7-publicacoes-impressas-maisantigas-do-brasil-e- do-mundo>.

$<$ http//www.stateofthenewsmedia.org/2009/narrative_newspapers_audience.php>.

<http://pt.wikipedia.org/wiki/PEC_37>.

<http://pt.wikipedia.org/wiki/Protestos_no_Brasil_em_2013>. 